\title{
Autoimmunity to cell surface receptors : immunopathology of acetylcholine receptors in experimental autoimmune myasthenia gravis in the rat
}

Citation for published version (APA):

de Baets, M. H. (1984). Autoimmunity to cell surface receptors : immunopathology of acetylcholine receptors in experimental autoimmune myasthenia gravis in the rat. [Doctoral Thesis, Maastricht University]. Leiter-Nypels. https://doi.org/10.26481/dis.19841026mb

Document status and date:

Published: 01/01/1984

DOI:

10.26481/dis.19841026mb

Document Version:

Publisher's PDF, also known as Version of record

Please check the document version of this publication:

- A submitted manuscript is the version of the article upon submission and before peer-review. There can be important differences between the submitted version and the official published version of record.

People interested in the research are advised to contact the author for the final version of the publication, or visit the DOI to the publisher's website.

- The final author version and the galley proof are versions of the publication after peer review.

- The final published version features the final layout of the paper including the volume, issue and page numbers.

Link to publication

\footnotetext{
General rights rights.

- You may freely distribute the URL identifying the publication in the public portal. please follow below link for the End User Agreement:

www.umlib.nl/taverne-license

Take down policy

If you believe that this document breaches copyright please contact us at:

repository@maastrichtuniversity.nl

providing details and we will investigate your claim.
}

Copyright and moral rights for the publications made accessible in the public portal are retained by the authors and/or other copyright owners and it is a condition of accessing publications that users recognise and abide by the legal requirements associated with these

- Users may download and print one copy of any publication from the public portal for the purpose of private study or research.

- You may not further distribute the material or use it for any profit-making activity or commercial gain

If the publication is distributed under the terms of Article $25 \mathrm{fa}$ of the Dutch Copyright Act, indicated by the "Taverne" license above, 


\section{AUTOIMMUNITY TO CELL SURFACE RECEPTORS}

Immunopathology of acetylcholine receptors in experimental autoimmune myasthenia gravis in the rat 



\section{AUTOIMMUNITY TO CELL SURFACE RECEPTORS}

Immunopathology of acetylcholine receptors in experimental autoimmune myasthenia gravis in the rat

\section{PROEFSCHRIFT}

ter verkrijging van de graad van doctor in de geneeskunde aan de Rijksuniversiteit Limburg te Maastricht, op gezag van de rector magnificus, Prof. Dr. H.C. Hemker, volgens besluit van het College van Dekanen, ter verdediging op 26 oktober 1984 om 16.00 uur

door

Marc H. De Baets

geboren te Gent in 1950

B.V. Leiter-Nypels - Maastricht 1984 
Promotor: Prof.dr. P.J.C. van Breda Vriesman

Referenten:Prof. Dr. F.T. Bosman

Prof. Dr. H.J.G.H. Oosterhuis

Prof. Dr. A. Vermeulen

CIP-DATA KONINKLIJKE BIBLIOTHEEK, DEN HAAG

De Baets, M.H.

Autoimmunity to cell surface receptors: immunopathology of acetylcholine receptors in experimental autoimmune myasthenia gravis in the rat / M.H. De Baets. - (S.1.: s.n.). - ill.

Thesis Maastricht. - With summary in Dutch.

ISBN 90-9000767-9

SISO 605.16 UDC 616.44

Subject headings: myasthenia Gravis / acetylcholine receptor / autoimmunity / cell membrane receptors. 
This thesis was designed in 1978 bij Prof. P.J.C. van Breda Vriesman and originated from a collaborative study between the Departments of Immunology (University of Limburg at Maastricht, the Netherlands) and Endocrinology (University of Gent, Belgium) on autoantibody mediated receptor disease specifically Graves disease. Since the only experimental model of antibody mediated receptor disease existing at that time was experimental autoimmune myasthenia gravis it was decided to use this model in order to analyze autoantibody receptor interactions.

A great number of people contributed to this study. Dr. J. Lindstrom (Receptor Laboratory, Salk Institute, La Jolla, California) who taught me the acetylcholine receptor isolation and radioimmunoassays for determining anti-acetylcholine-receptor antibody. The in vitro studies, presented in Chapter III of this thesis were done in the laboratory of Prof. W.O. Weigle, Department of Immunopathology, Scripps Clinic and Research Foundation. The experiments presented in Chapter IV, V and VI were performed at the Department of Immunology, University of Limburg at Maastricht (Prof. Dr. P.J.C. van Breda Vriesman). The majority of experiments were performed by ms. L.F.M. Vlek, ms. P. Storms, and last but not least mrs. A. de Baets-Janssens. The isoelectrofocusing experiments were done in a collaborative study with $\mathrm{A}$. Bionda and A.N. Theophilopoulus (Scripps Clinic and Research Foundation).

The work would not have been possible without a Fogarty fellowship, and grants from the Rijksuniversiteit Limburg and the Prinses Beatrix Foundation.

Mrs. C. Bollen and also F. Teng and R. le Doux assisted with the typing of the manuscript and Dr. G. Majoor with the translation of the summary. 

Only a poet not a scientist can say "Exegi momentum aere perennius", (Horatius, Carmina $\mathrm{II}, 30, \mathrm{I})$ 


\section{ABBREVIATIONS}

\begin{tabular}{|c|c|c|c|}
\hline$a b$ & Antibody & $\mathrm{pI}$ & Isoelectric point \\
\hline$\alpha-\mathrm{BGT}$ & $a$-bungarotoxin & \multicolumn{2}{|c|}{ RCM-AChR Reduced and carboxy- } \\
\hline $\mathrm{ACh}$ & Acetylcholine & & methylated acetylcholine \\
\hline $\mathrm{AChR}$ & Acetylcholine receptor & & receptor \\
\hline BSA & Bovine serum albumin & $\mathrm{SC}$ & Spleen cells \\
\hline cAMP & Cyclic-adenosine & SDS & Sodium dodecyll sulfate \\
\hline & monophosphate & $\mathrm{t}-\mathrm{AChR}$ & Trypsinized acetylcholine \\
\hline CFA & Complete Freund's adjuvant & & receptor \\
\hline Con-A & Concanavalin $\mathbf{A}$ & TBII & Thyrotropin binding inhibiting \\
\hline DNP & Dinitrophenol & & immunoglobulins \\
\hline DS & Dextran sulphate & TCGF & T cell growth factor \\
\hline DTH & Delayed type hypersensitivity & {$\left[{ }^{3} H\right] T \mathrm{TdR}$} & Tritiated thymidine \\
\hline EAE & Experimental autoimmune & & desoxyribose \\
\hline & encephalomyellitis & $\mathrm{TG}$ & Thyroglobulin \\
\hline EAMG & $\begin{array}{l}\text { Experimental autoimmune } \\
\text { myasthenia gravis }\end{array}$ & TGI & $\begin{array}{l}\text { Thyroid growth stimulating } \\
\text { immunoglobulin }\end{array}$ \\
\hline EAT & Experimental autoimmune & TSab & Thyroid stimulating antibody \\
\hline & thyroiditis & TSH & Thyrotropin \\
\hline ELISA & $\begin{array}{l}\text { Enzyme linked immunosorbent } \\
\text { Assay }\end{array}$ & & $\begin{array}{l}\text { Thyroid stimulating } \\
\text { immunoglobulins }\end{array}$ \\
\hline FACS & Fluorescence-activated cell sorter & & \\
\hline $\mathrm{FCS}$ & Fetal Calf serum & & \\
\hline FSH & Follicle stimulating hormone & & \\
\hline HBSS & Hank"s balanced salt solution & & \\
\hline HLA & Human leucocyte antigens & & \\
\hline Ia & $\begin{array}{l}\text { Immune response region } \\
\text { associated }\end{array}$ & & \\
\hline IEF & Isoelectric focusing & & \\
\hline $\operatorname{Ig} \mathrm{G}$ & Immunoglobulin $\mathrm{G}$ & & \\
\hline IL-1 & Interleukin 1 & & \\
\hline IL-2 & Interleukin 2 & & \\
\hline i p. & Intraperitoneal & & \\
\hline $\mathrm{LNC}$ & Lymph node cells & & \\
\hline LPS & Lipopolysaccharide & & \\
\hline $\mathrm{MAB}$ & Monoclonal antibody & & \\
\hline MEPP & Mini endplate potential & & \\
\hline $\mathrm{MHC}$ & $\begin{array}{l}\text { Major histocompatibility } \\
\text { complex }\end{array}$ & & \\
\hline MIR & Main immunogenic region & & \\
\hline $\mathrm{MO}$ & Myasthenia gravis & & \\
\hline$N P-40$ & Nonidet-P-40 & & \\
\hline NZB & New Zealand Black mice & & \\
\hline NZW & New Zealand White mice & & \\
\hline PAGE & $\begin{array}{l}\text { Polyacrylamide } \\
\text { gel-electrophoresis }\end{array}$ & & \\
\hline PBL & Peripheral blood lymphocyte & & \\
\hline PBS & Phosphate buffered saline & & \\
\hline PMSF & Phenyl methyl sulfonylfhuoride & & \\
\hline
\end{tabular}




\section{CONTENTS}

INTRODUCTION

CHAPTER I : Autoimmune receptor diseases

1.1 Introduction

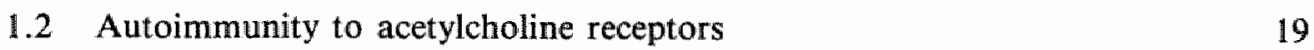

$\begin{array}{ll}1.3 & \text { Autoimmunity to thyrotropin receptors } \\ 1.4 & 21\end{array}$

1.4 Autoimmunity to insulin receptors $\quad 22$

1.5 Autoimmunity to $\beta$-adrenergic receptors 23

1.6 Autoimmunity to parathyroid hormone receptors 23

1.7 Autoimmunity to follicle-stimulating hormone receptors 23

$\begin{array}{ll}1.8 & \text { Autoimmunity to transferrin receptor } \\ 1.9 & 24\end{array}$

1.9 Autoimmunity to other receptors 24

1.10 Concepts on autoimmunity applied to anti-receptor diseases 25

CHAPTER II : The experimental autoimmune myasthenia gravis animal model.

2.1 Introduction

2.2 Autoantigen: The acetylcholine receptor $(\mathrm{AChR}) \quad 33$

$\begin{array}{ll}2.2 .1 \text { Biochemistry of acetylcholine receptors } & 34\end{array}$

$\begin{array}{ll}\text { 2.2.2 Acetylcholine receptor function } & 34\end{array}$

$\begin{array}{ll}2.2 .3 \text { Synthesis and destruction } & 35\end{array}$

2.2.4 The antigenic anatomy of acetylcholine receptors 35

2.3 Induction of experimental autoimmune myasthenia gravis (EAMG) 36

$\begin{array}{ll}2.3 .1 \text { EAMG in rats } & 37\end{array}$

2.3.2 EAMG in mice $\quad 37$

2.4 The humoral immune response to acetylcholine receptors 39

$\begin{array}{ll}\text { 2.4.1 Specificity of the antibodies } & 39\end{array}$

2.4.2 Mechanisms of the humoral immune attack 40

a) complement mediated lysis of the muscular cell membrane $\quad 40$

b) Antigenic modulation of AChR $\quad 40$

c) Direct blockade of AChR function by antibody 41

2.5 The cellular immune response to acetylcholine receptor

2.6 Pathology of the neuromuscular endplate in EAMG 44

2.7 Relevance of the EAMG model for myasthenia gravis 45 
CHAPTER III: Immunogenicity of Acetylcholine Receptors: in vitro studies

3.1 Introduction

3.2 Design of the experiments 54

3.2.1. lymphocyte proliferation culture system $\quad 54$

3.2.2. antibody synthesis in vitro 55

3.3 AChR-induced lymphocyte proliferation 55

3.3.1. The proliferative response of lymphoid cells from various anatomic 55 sites

3.3.2 The immunogenicity of soluble $\mathrm{AChR}$, native membranes and liposome incorporated $\mathrm{AChR}$

3.3.3 Effect of the main immunogenic region (MIR), the sites outside the MIR, and the subunits of Torpedo $\mathrm{AChR}$, on the in vitro proliferative responses

3.4 AChR-induced specific antibody production in vitro

3.4.1 The effect of chemical alteration of $A C h R$ on the in vitro antibody responses

3.4.2. Immunogenicity and pathogenicity of AChR 66

3.5 On the cellular mechanisms of the secondary in vitro response to AChR 69

3.5.1 The cellular requirements for the secondary in vitro proliferative and antibody response to $\mathrm{AChR}$

3.5.2 The role of lymphokines, specifically interleukin-2

$\begin{array}{lll}3.6 & \text { Discussion } & 74\end{array}$

$\begin{array}{lll}3.7 & \text { Summary and Conclusions } & 78\end{array}$

CHAPTER IV : Immunogenicity and Pathogenicity of Acetylcholine Receptors in wivo studies

4.1 Introduction

4.2 Design of the experiments

4.3 Induction of experimental autoimmune myasthenia gravis (EAMG) by active immunization with native acetylcholine receptor.

4.3.1 Immunogenicity of the AChR and kinetics of the serum antibody response

4.3.2 Binding of antibody cross-reactive with muscle AChR to the endplate

4.3.3 Dose dependency of the immune response against $\mathrm{AChR}$ and myasthenia

4.4 The role of the main immunogenic region in EAMG

4.4.1 The antigenic anatomy and physicochemical characteristics of biochemically altered $\mathrm{AChR}$ 
4.4.3 RCM-AChR does not protect against EAMG

4.4.4. Cross-reactive antibody elicited by $\mathrm{RCM}-\mathrm{AChR}$ binds to in viro non-accessible antigenic sites on the rat $\mathrm{AChR}$

4.4.5 Passive transfer of EAMG by monoclonal antibodies

4.5 Passive transfer of EAMG with immune lymphocytes

4.6 Discussion

4.7 Summary and Conclusions

CHAPTER V: Anti-AChR-antibody - Acethylcholine receptor interactions: Analysis of mechanisms that influence the severity of myasthenia

5.1 Introduction

5.2 Role of antibody to the acetylcholine binding site in chronic $\mathbb{E A M G}$

5.3 Role of antibody diversity in EAMG

5.3.1 Separation of complexed antibodies from antigens by isolectric focusing

5.3.2 Sensitivity and specificity of analytical IEF of antibodies to Torpedo AChR

5.3.3 Isoelectric spectra of antibodies to Torpedo and muscle $\mathrm{ACh} R$

5.3.4 Analysis of tissue deposited antibodies

5.4 Discussion

5.5 Summary and Conclusions

CHAPTER VI: Effect of AChR synthesis on the severity of EAMG

6.1 Introduction

6.2 Effect of unilateral denervation ( $\mathrm{n}$. ischiadicus) on the severity of EAMG induced by passive transfer of monoclonal antibody

6.3 Effect of unilateral denervation ( $\mathrm{n}$. ischiadicus) on the severity of EAMG induced by active immunization with Torpedo AChR

6.4 Effect of anabolic steroids nandrolone on EAMG

6.5 Discussion

6.6 Summary and Conclusions

SUMMARY 



\section{INTRODUCTION}

Autoimmunity against a receptor defines immunological reactions against. "self" glycoproteins which are embedded in the cell membrane. The immune reactions may be physiologic when in the course of an immune response to a given antigen, antibodies to B-cell receptors (= anti-idiotypic antibodies) are elicited (1). Autoimmunity can be pathologic when the immune reactions cause signs of disease because of receptor loss (2) or receptor stimulation (3). The clinical spectrum of these autoimmune receptor diseases is described in chapter I of this thesis.

Clinically analysis of the pathogenesis of disease, in this context autoimmune receptor disease, is usually greatly hampered by the absence of suitable animal models. This is well illustrated by two autoimmune receptor diseases: Graves' disease and myasthenia gravis. It was suggested in 1956 (4) and known since 1962 (5) that Graves' disease is an autoimmune disorder caused by circulating antibodies to TSH receptor (thyroid stimulating hormone) on thyroid cells. The absence of an animal model has insured that now, over two decades later, little is known about the TSH receptor or its interaction with autoantibodies; and scientists are still searching for a convenient assay to measure these antibodies. In contrast the hypothesis that myasthenia gravis might be caused by autoantibodies to the acetylcholine receptor was only proposed in the beginning of the seventies (6). Next Patrick and Lindstrom developed an animal model for this disease in $1973(7)$ and a few years later a clinical useful assay was available for diagnosis and follow up of patients with myasthenia gravis (8).

Since we were interested in the pathogenesis and therapeutic manipulation of autoimmune receptor diseases the state of the art dictated, experimental myasthenia gravis as model system for these diseases (fig. 1). This model is described in Chapter II.

Conceptually, a therapeutic approach to autoimmune receptor diseases requires precise information about immune reactions involved and target organ characteristics. Both manipulation of the immune response or the target organ might ameliorate disease. Since Lindstrom et al. had spended great effort to characterize the acetylcholine receptor - a joint effort with Dr. J.M. Lindstrom (Receptor Biology Laboratory at the Salk Institute) and Dr. W.O. Weigle (Scripps Clinic and Research Foundation) was created in order to characterize the immune reactions involved in experimental autoimmune myasthenia gravis in vitro. The question asked was which humoral and cellular immune reactions were involved in experimental autoimmune myasthenia gravis. Although in any given immune reaction both $\mathrm{T}$ and $\mathrm{B}$ cells are involved there may be $\mathrm{T}$ or $\mathrm{B}$ cell preponderance in the effector arch as illustrated by the following experimental diseases. In experimental autoimmune allergic encephalitis $T$ cells are important effector cells although antibodies to basic myelin protein are demonstrated (9). In ex- 

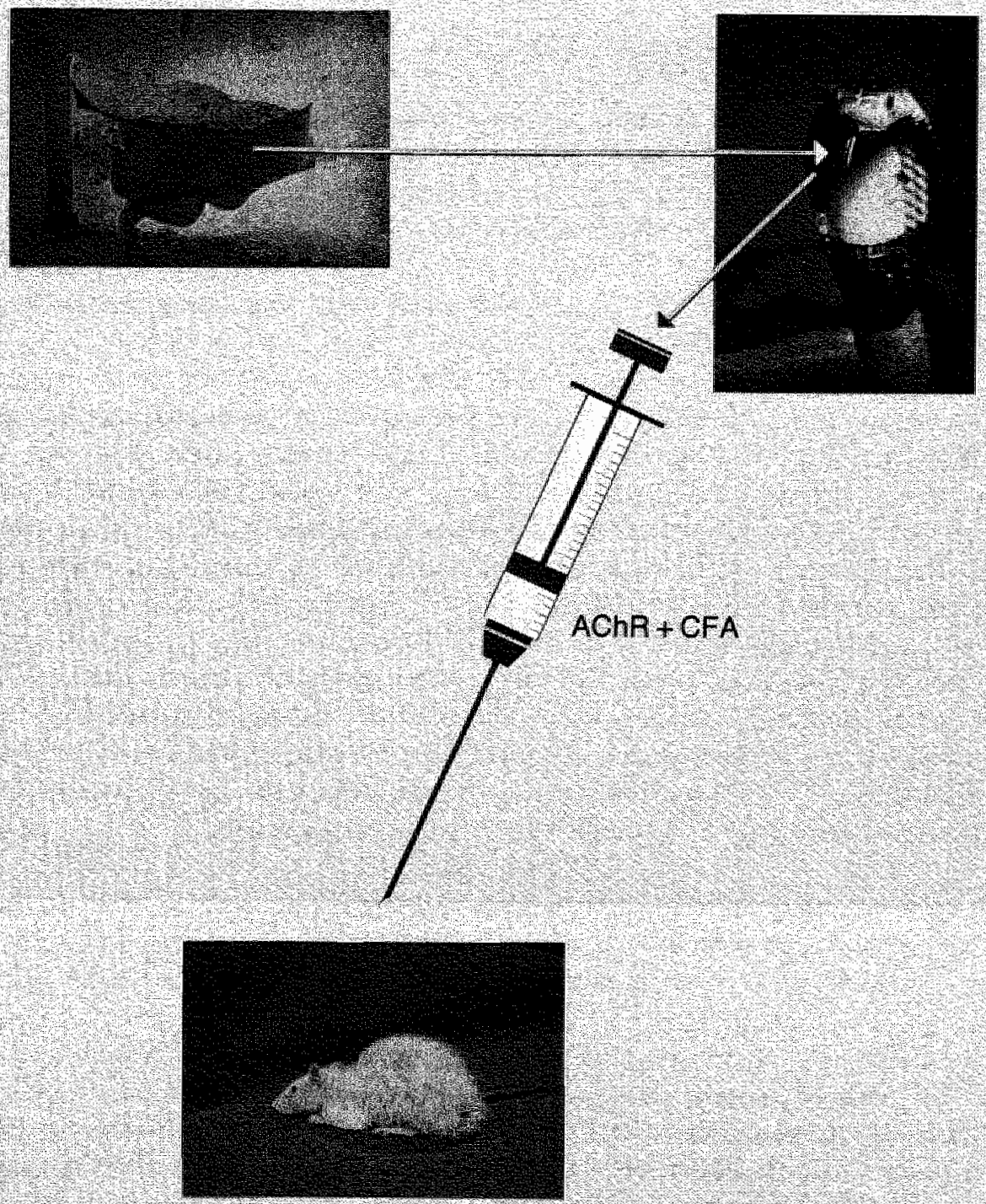

Fig. I Induction of experimental autoimmune myasthenia gravis in the rat. Acetylcholine receptors are isolated from the electric organs of Torpedo californica by affinity chromatography on Cobra toxin coupled to agarose beads. The purified acetylcholine receptors incorporated in complete Freund's adjuvant are injected into experimental animals (rats). These animals develop experimental autoimmune myasthenia gravis, a disease that resembles myasthenia gravis in man. 
perimental autoimmune myasthenia gravis antibodies are thought to be important and little is known about cellular immune mechanisms (10). At the onset of the study the rat was chosen as an experimental animal. This choice was made because inbred strains were available and the immune system is well characterized. The rats - in contrast to mice - develop clinical myasthenia after immunization with acetylcholine receptors whereas mice are rather resistant (10). In chapter III an in vitro lymphocyte culture system is described which allows the study of the immunogenicity of several AChR preparations and the analysis of the differing lymphocyte subsets operative in EAMG. These in vitro findings were next confirmed in an in wivo model (chapter IV).

Next, we analyzed which category of antibodies mediated the disease. Since experimental autoimmune myasthenia gravis is induced by immunizing rats with acetylcholine receptors isolated from electric eel or Torpedo californica the question asked was which crossreactive antibodies mediated the disease. Therefore the relationship between immunogenicity of various acetylcholine receptor preparations, crossreactive antibodies binding to rat acetylcholine receptor and myasthenia gravis was analyzed in vivo (chapter IV). The experiments described in chapter IV strongly supported the view of that myasthenia gravis in the experimental model was brought about by antibodies binding to a discrete part of the rat acetylcholine receptor. In other words these experiments suggested that antibody specificity might be of great importance in experimental autoimmune myasthenia gravis (EAMG). This is an important issue in terms of immunotherapy of the disease, for if the pathogenitically important antibody response could be shown to be highly specific and restricted, then therapy with antiidiotypic antibody might influence disease (12). The studies on antibody specificity and restriction are described in chapter $\mathrm{V}$. The results obtained in chapter IV and $\mathrm{V}$ strongly suggested that apart from crossreactive antibody titers, target organ characteristics determined the severity of disease. In chapter VI a therapeutic approach to experimental autoimmune myasthenia gravis is described which originated from efforts to increase target organ resistance to autoantibody mediated acetylcholine receptor loss from muscle. 


\section{References}

1. Cosenza H. Detection of anti-idiotype reactive cells in the response to phosphorylcholine. Eur. J. Immunol. 6: 114-116, 1976.

2. Hënemann $S$, Bevan $S$, Kullberg $R$, Lindstrom $J$, Ruce $J$. Modulation of acetylcholine receptor by antibody against the receptor. PNAS USA 74: 3090-3094, 1977.

3. Smith $\mathbb{B R}$, Hall $\mathbb{R}$. Thyroid stimulating immunoglobulins in Graves'disease. Lancet ii: $427-431,1974$.

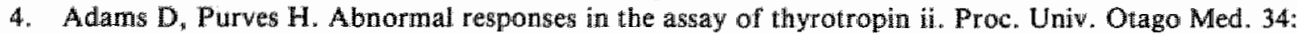
$11-12,1956$.

5. Adams DD, Kennedy Th. Association of long acting thyroid stimulator with the gamma globulin fraction of serum. Prac. Univ. Otago Med. Sch. 40: 6-7, 1962.

6. Lennon VA, Carnegie PR. Immunopharmacological diserase : a break of tolerance to receptor sites. Lancet i: $630-633,1971$.

7. Patrick J, Lindstrom J. Autoimmune response to acetylcholine receptor. Science 180: 871-872, 1973.

8. Lindstrom $\mathrm{J}$. An assay for antibodies to human acetylcholine receptor in serum from patients with myasthenia gravis. Clin. Immunol. and Immunopath. $7: 36-43,1977$.

9. Weigle WD. Analysis of autoimmunity through experimental models of thyroiditis and allergic encephalomyelitis. Adv. Immunology 30: 159-273, 1980.

10. Lindstrom I. Autoimmune response to acetylcholine receptors in myasthenia grawis and its animal model. Adv. Immunol. 27: 1-50, 1979.

11. Berman P and Patrick J. Linkage between the frequency of muscular weakness and loci that regulate inmume responsiveness in murine experimental myasthenia gravis. J. Exp. Med. 152: 507-520, 1980.

12. Miller RA, Maloney $D G$, Warnke $R$, Levy $\mathbb{R}$. Treatment of $\beta$-cell lymphona with monoclonal antiidiotype antibody. N. Eng. J. Med. 306: 517-522, 1982. 


\section{CHAPTER I}

\section{Autoimmune receptor diseases}

\subsection{INTRODUCTION}

Cell surface receptors are antennas designed to receive information and stimuli carried by means of messengers residing in the extracellular fluid; these messengers include hormones, neurotransmitters, trophic factors, and immunogens. After binding of the messenger - also called ligand - to the receptor, cell function is modulated. The receptor concept therefore implies both formation of a complex between receptor and messenger (ligand), activation of the receptor, and a demonstrable biological effect on the cell function by means of activation of the receptor; in other words, the binding of a ligand to a cell membrane implies the presence of a receptor only when the binding results in a specific biological activity on the part of the cell.

The receptor concept was already introduced at the turn of the century by Langley (1) who held that striated muscle cells contained a "receptive substance" and a "chief substance"; the latter was required for the specific biological function of the striated muscle cell : contraction. In the "receptive substance"; we have a description of a true receptor, the acetylcholine receptor, "avant la lettre". Although Ehrlich - also at the turn of the century - coined the term "receptor", and Ehrlich is still alluded to today when describing immunoglobulin receptors on the surface of B lymphocytes, Ehrlich theorized only about highly specific "side chains", residing in the cell protoplasm; these unique chemical structures he held could serve as "receptors" for chemotherapeutic drugs (2). Clearly Ehrlich described no receptor in the modern sense of the word for a substance that can bind to another substance does not necessarily imply a biologically active ligand.

Several types of membrane receptors have been shown to exist. Peptide hormone receptors activate a cascade of enzymes including adenylate cyclases $(1,2)$ and protein kinases (5). Neurological receptors are more directly involved in cellular events through ion channels allowing acute changes in intracellular ion compensation resulting in neuroactivation or muscle contraction (6). Immunological receptors are modulated by antigen or anti-antibodies ( = anti idiotypic antibodies) resulting in cell proliferation and differentiation (7). These immunological receptors were the first receptors to be characterized by technology developed because of the existence of plasma cell tumors, secreting large amounts of homogenous antibodies. Recent advances in genetic engineering have made it possible to detect the subtle difference in cell bound i.e. receptor immunoglobulin and secretory immunoglobulin (8). The acetylcholine receptor was next on the list of new discoveries of cell surface receptor molecules (9). Both (purified) snake toxins and electric organ from Electroforus Electricus (electric eel) were of great 
help in the purification of AChR. The specific high affinity binding of cobra toxin to AChR which are present in large quantities in the eel's electric organ, allowed Karlin and several others (9) to isolate an integral membrane protein. Further research in this field was hampered by extensive proteolysis resulting in isolation of small peptides with no receptor function. In the last decade a vast array of receptors have been purified to homogeneity. First by use of ligand-affinity columns and later on by lectins and more recently also by insolubilized monoclonal anti-receptor antibodies.

The concept of autoimmunity was developed prior to most of the above mentioned technology was available. Indeed, in 1956, Roitt and Doniach demonstrated antibodies against thyroglobulin in patients with Hashimoto's thyroiditis (10). In the same year Rose and Witebsky developed an animal model for this disease (11). These authors, probably inspired by Koch's postulates, formulated new criteria for the definition of autoimmune diseases (Table I).

Table I : Criteria for establishing the autoimmune etiology of an organ-specific human disease (12)

(1) Autoantibodies reactive at body temperature, or evidence of cell-mediated immunity.

(2) Isolation and purification of the organ-specific antigens.

(3) Production of autoamtibodies to organ-specific antigen in experimental animals.

(4) Development of similar lesions in autosensitized animals.

In 1960, when the idea of autoimmunity inspired thinking in clinical medicine Simpson postulated that myasthenia gravis (MG) was due to an autoimmune attack upon a protein of the motor endplate (13). This concept was inspired by the fact that MG was frequently associated with disorders of the blood the reticulo-endothelial system and systemic lupus erythematosus; other arguments were abnormalities of the thymus, the presence of lymphorrhages in muscles, the fluctuating course of the disease and above all the occurence of transient neonatal MG (13). Nastuk et al. observed that the sera of some MG patients were cytotoxic for muscle cells (14). They also found that complement levels were lower during the clinical exacerbation of MG. The idea that antibody to a membrane receptor could be a cause of disease was first put forward by Carnegie. He speculated that the encephalitogenic determinant on myelin basic protein, used to induce experimental autoimmune encephalomyelitis, was remarkably similar to the estimated requirements for a serotonin receptor (15); this hypothesis has never been substantiated however. The concept of autoimmunity to cell surface receptors has been lately extended to other diseases and referred to as immunopharmacological disease (16).

Based on these concepts animal models for the study of antireceptor diseases were developed. Patrick and Lindstrom demonstrated that antibodies against acetylcholine receptors from electric organ of an electric eel could interfere with the neuromuscular transmission in the rabbit (17). The autoimmune nature of myasthenia gravis was further demonstrated by Lennon and Lindstrom in rat and guinea pig (18). The 
Table II. Autoimmune diseases associated with anti receptor antibodies

\begin{tabular}{|c|c|c|}
\hline Receptor for & Disease & Reference \\
\hline Acetylcholine (nicotinic) & myasthenia gravis & (17) \\
\hline Thyroid stimulating & Thyrotoxicosis $(\mathrm{TSI})^{\mathrm{a}}$ & (20) \\
\hline \multirow[t]{3}{*}{ hormone } & Simple goitre $(\mathrm{TGI})^{\mathrm{b}}$ & (21) \\
\hline & Primary myxoedema & \\
\hline & $($ TGI-block) & (22) \\
\hline \multirow[t]{2}{*}{ Insulin } & Insulin resistance & (23) \\
\hline & Hypoglycemia & (24) \\
\hline Parathyroid hormone & $\begin{array}{l}\text { Secondary hyperpara- } \\
\text { thyroidism in renal failure }\end{array}$ & (25) \\
\hline Gastrin & Pernicious anemia & (26) \\
\hline$\beta$-adrenergic agonists & Asthma and allergic rhinitis & (27) \\
\hline $\begin{array}{l}\text { Follicle stimulating } \\
\text { hormone }\end{array}$ & Amenorrhoe & (28) \\
\hline Transferrin & Anemia & $(29,30)$ \\
\hline \multicolumn{3}{|c|}{$\begin{array}{l}\text { a) TSI: thyroid stimulating immunoglobulin; } \\
\text { b)TGI: thyroid growth promoting immunoglobulins; } \\
\text { 'TGI-block: thyroid growth inhibiting immunoglobulins. }\end{array}$} \\
\hline \multicolumn{3}{|c|}{ Table III. Anti receptor antibodies exerting agonist like effect } \\
\hline Receptor & Cellular response & Reference \\
\hline TSH & thyroid hormone secretion & (31) \\
\hline Insulin & glucose uptake & (24) \\
\hline Prolactin & casein synthesis & (32) \\
\hline Epidermal growth factor & DNA synthesis & (33) \\
\hline
\end{tabular}

demonstration of antibodies against $\mathrm{AChR}$ 's in myasthenia gravis patients proved the existence of antireceptor diseases in man (19). Since then several autoimmune receptor diseases have been identified (table II) clinically mainly through the development of assays to measure anti receptor antibodies. A number of antibodies can exert an agonist like effect (table III). These diseases are now reviewed separately.

\subsection{AUTOIMMUNITY TO ACETYLCHOLINE RECEPTORS}

Myasthenia gravis is a disease affecting the neuromuscular junction resulting in abnormal weakness and fatigability of some or all voluntary muscles. The weakness increases with repeated or sustained exertion and is improved by rest. These signs respond to anticholinesterase drugs which act increasing the amount of available acetylcholine. External ocular muscles are affected initially in approximately $50 \%$ and eventually in about $90 \%$ of the patients. Other voluntary muscles innervated by cranial nerves and 
cervical, pectoral-girdle and hip flexor muscles are also frequently affected; proximal limb muscles are usually more severely affected than distal ones. The deep tendon reflexes are brisk or normally active. There are no objective sensory deficits. The signs of the disease fluctuate from day to day, week to week and spontaneous remission can occur for varying periods of time (34-36).

The evidence for an autoimmune etiology of $\mathrm{MG}$ includes clinical and epidemiological arguments. As already suggested by Simpson an association exists with other diseases of autoimmune etiology, MG has a fluctuating course, and a transient neonatal disease exists (13). MG predominates in females of $15-40$ year of age (reviewed in 37) and is associated with HLA-A1-B8 (38-47) in caucasians and with HLA-B12 (48) and Gm allotypes in the japanese population (49). A favourable reaction to corticosteroids and/or immunosuppressive agents is seen (reviewed in 50). These clinical and epidemiological evidence prompted several investigators to search for immunopathological data to prove the autoimmune etiology of MG. This search resulted in the fullfilment of the four criteria of Witebsky and Rose (12). Almost all patients with myasthenia gravis have circulating antibodies against $\mathrm{AChR}$ as measured by a double antibody immunoprecipitation assay using ${ }^{125} \mathrm{I}-\alpha$-bungarotoxin-labeled human $\mathrm{ACh}$ $(51-53,46)$. Anti-AChR antibodies can also be detected in the blood of babies born to myasthenic mothers (54-56) and a small number of these babies (12\%) show weakness at birth (57). MG can also be transferred from man to mice by means of serum (65). There is also evidence of cell mediated immunity against $\mathrm{AChR}$ as measured by peripheral blood lymphocyte proliferation assays (reviewed in 58). The AChR has been purified from the electric organ of electric fish and from mammalian muscle (reviewed in 59). Injection of acetylcholine receptors in complete Freund's adjuvant (CFA) into

Table IV : Myasthenia gravis is an autoimmune disease :

\section{A. Clinical and epidemiological evidence}

1. Association with other autoimmune disease, high prevalence of autoantibodies other than AChR antibody (rheumatoid arthritis in females, hyperthyroidism)

2. Fluctuating course

3. Female predominance $(3: 1,15-40 \mathrm{yr})$

4. Genetic predisposition (HLA A 1-B8; Gm allotypes)

5. Favourable reaction to corticosteroids and immunosuppressive agents

\section{B. Immunopathological evidence (criteria of Witebsky and Rose)}

1. Anti-AChR antibodies are detectable in $85-90 \%$ of patients with the disorder. There is also evidence of cell-mediated immunity against AChR.

2. The acetylcholine receptor, one of the organ-specific antigens, has been purified.

3. Injection of acetylcholine receptors in Freund's complete adjuvant into animals induces the production of autoantibodies

4. The lesions present at neuromuscular endplate in animals injected with acetylcholine receptors are similar to those in patients with myasthenia gravis. 
experimental animals induced the production of autoantibodies (reviewed in 60) and myasthenia (see chapter II). In these animals the immunopathological lesions including the anti-AChR antibody and complement deposited at the neuromuscular endplate resemble to a considerable extent the post-synaptic neuromuscular lesions observed in myasthenia gravis $(61-64)$.

\subsection{AUTOIMMUNITY TO THYROTROPIN RECEPTORS}

Graves' disease is characterized by overproduction of the thyroid hormones thyroxine and triiodothyronine, resulting in a state of metabolic hyperactivity. The probable cause of these features is the interaction of thyroid-stimulating immunoglobulins (TSI) with the TSH receptor or a closely adjacent site on the membranes of the epithelial cells lining the thyroid follicles (31). Morphologically, Graves' disease is characterized by diffuse hyperplasia of the acinar tissue and usually foci of lymphocytic infiltration. Antibodies against the TSH receptors were discovered by chance when sera from patients with thyrotoxicosis due to Graves' disease were tested for thyrotropin acitivity in a guinea pig bioassay (66). A substance in these sera, later identified as immunoglobulin G, induced a long acting thyroid stimulation (LATS) when compared to thyrotropin $(20,67)$. The majority of patients with Graves' disease, however, were LATS negative. A second factor, LATS-protecting factor which competes with LATS for human thyroid tissue was identified (68). LATS-Protector is a human specific thyroid stimulating antibody which does not cross-react with the bioassay in animals (68). Infusion of sera with LATS-P activity into normal human volunteers stimulated their thyroids thus proving that LATS-P was a true thyroid stimulator. (69). Since then a large array of in vitro assays for thyroid stimulation have been developed (70,71). Two in vitro assays using human thyroid membranes are clinically useful. The first measures the inhibition of binding of radiolabelled highly purified thyrotropin (TSH) to human thyroid plasma membranes by immunoglobulin from the sera of patients with Graves" disease (TBii thyrotropin binding inhibition immunoglobulins). A second assay measures the activation of the TSH receptor-adenylate cyclase complex by Graves' IgG (TSi or TSab: thyroid stimulating immunoglobulin or antibodies) on human thyroid membranes or thyroid slices $(72,73)$.

Recently a second population of antibodies to the TSH receptor, affecting thyroid cell growth was identified (21).In the sera of patients with goitrous form of Graves' disease or with simple goitre, immunoglobulins that stimulate thyroid cell growth in vitro are detectable. These thyroid growth immunoglobulins (TGi) may induce goitre formation in Graves" disease and simple goitre. Patients with atrophic thyroiditis have circulating antibodies that block TSH induced thyroid cell growth in vitro (TGI-block) (22).

Despite the fact that these antibodies are well characterized no experimental model for Graves" disease has been developed. Immunization of rabbits with bovine thyroid membranes results in the generation of antibodies to thyroglobulin and microsomal antigens much like that in humans, the equally characteristic thyrotoxicosis (74) is not 
observed in animals however. The failure to develop an experimental model does not result from target insensitivity in rodents, as the transfer of human lymphocytes from patients with Graves' disease into nude mice temporarily elevates their thyroid hormone levels (75); however restricted heterogeneity - c.q. oligoclonality of thyroid stimulating immunoglobulin - might be necessary for the development and continuation of the disease (76). Immunization of animals with TSH receptors in thyroid membranes produces a polyclonal antibody response probably combining blocking and stimulating antibodies directed against $\mathrm{TSH}$ receptor and other membrane constituents.

\subsection{AUTOIMMUNITY TO INSULIN RECEPTORS}

Some patients with diabetes display an extreme form of insulin resistance associated with acanthosis nigricans which is attributable to antibodies against the insulin receptors. These patients have presented with symptomatic diabetes, resistant to extremely high doses of insulin (up to $24.000 \mathrm{U} / \mathrm{day}$ ). As with other autoimmune diseases females are more frequently affected than males. Nearly all patients have acanthosis nigricans, a skin disorder characterized by pigmented thickening of the skin over the extensor surfaces of the joints, the neck, frequently extending over the trunk and face. The skin lesions may regress simultaneously with the insulin resistance. Some periods of hypoglycemia may occur. Hypoglycemia may allso occur without a previous period of insulin resistance. In patients with autoimmune disease presenting with fasting hypoglycemia and clinical evidence for an insulinoma, the diagnosis of anti receptor autoimmunity should be considered (24).

The mononuclear lymphocytes and probably all cells expressing insulin receptors in these patients have a markedly decreased ability to bind insulin. This receptor defect is due to antibodies against the insulin receptor. When tested in short term cultures these anti-receptor antibodies have an insulin-like effect. This effect predominates in patients with autoimmune hypoglycemia. However, prolonged exposure of adipocytes to anti-receptor antibodies results in desensitization of the insulin receptor, a phenomenon observed in vivo in patients with the above-described diabetic syndrome. (77). The molecular basis of these effects is unknown, but the evidence suggests that they are mainly due to allosteric changes in binding site conformation rather than to direct "competitive" effects at the binding site (78). Chronic exposure to anti-insulin receptor antibodies induced receptor loss (78). Such antibodies can be detected with competitive binding assay in which ${ }^{125}$ I-Insulin is allowed to react with peripheral blood monocytes or the human cell line IM-9 in the presence of a patient's serum (23). Alternatively, an immunoprecipitation method can be used to demonstrate antibodies that react with a preparation of solubilized insulin receptors purified from placental membranes (79). An animal model for this disorder is the New Zealand obese mice (NZO), related to NZB and NZW lupus prone mice, which contain besides antibodies against single and double stranded DNA also anti-insulin receptor antibodies. These 
antibodies are of low titer and IgM class. Dense glomerular deposits of IgM are detectable in the kidneys of these animals (80).

\subsection{AUTOIMMUNITY TO- $\beta$-ADRENERGIC RECEPTORS}

Autoantibodies to $\beta$-adrenergic receptors have been identified occasionally in sera of patients with asthma and allergic rhinitis and patients with autonomic dysfunction (27). To detect these antibodies, $\beta$-adrenergic receptors isolated from lung or placental tissues are radiolabelled with a high-affinity $\beta$-adrenergic agonist ${ }^{125}$ I-hydroxybenzylpindolol) and incubated with the patient's serum. Immune complexes formed in this assay are precipitated by a second antibody. In some sera antibodies were directed at or near the ligand-binding site of the $\beta_{2}$-receptor (27). The presence of these antibodies is also associated with autonomic abnormalities characterized by $\alpha$-adrenergic and cholinergic hypersensitivity and $\beta$-adrenergic hyposensitivity due to imbalance between the ortho- and parasympathic system. Subjects with antibodies required higher doses of isoproterenol to ellevate their pulse pressure and plasma cAMP indicating $\beta$ adrenergic hyporesponsiveness. An increased $\alpha$-adrenergic and cholinergic sensitivity was present as measured by the effects of the $\alpha$-adrenergic agonist and the cholinergic agent carbachol phenylephrine on pupillary dilation and constriction respectively (81). The role of anti-adrenergic antibodies in the pathogenesis of asthma is less clear. A $\beta$ adrenergic theory of atopic asthma proposes an imbalance of the autonomic control with decreased $\beta$-adrenergic sensitivity of bronchial smooth muscle, mucous glands and mucosal vessels (82). An autoantibody induced $\beta$-receptor defect may be an intrinsic feature of asthma. No experimental model exists.

\subsection{AUTOIMMUNITY TO PARATHYROID HORMONE RECEPTORS}

In uremic patients with secondary hyperparathyroidism a high frequency of autoantibodies can be detected which block the binding of parathormone to its receptor (25). The inhibition of parathormone binding by these antibodies is accompanied by functional alterations of the parathormone receptors detected as an impaired stimulation of cAMP formation by parathormone in kidney tubular membranes. The biological significance of these antibodies is ill defined; however, blocking of the parathormone receptor might increase the circulating levels of parathormone and its metabolites. Accumulation of these long-lived peptides might be responsible for abnormalities like hyperlipidaemia, impaired motor-nerve conduction and anemia, which have been said to be due to a uraemic toxin but may be due to high levels of non-aminoterminal containing parathormone metabolites (25).

\subsection{AUTOIMMUNITY TO FOLLICLE-STIMULATING HORMONE RECEPTORS}

Two patients with hypergonadotropic amenorrhea and myasthenia gravis had cir- 
culating antibodies to the follicle stimulating hormone receptor (FSH) (28). The diagnosis of gonadotropin-resistant ovary syndrome was made on the basis of high serum gonadotropin levels and the presence of numerous cortical primordial follicles in an ovarian biopsy. Antibodies against the FSH receptor were demonstrable in a radioreceptor assay. In this assay the patient's immunoglobulin $\mathrm{G}$ competed with ${ }^{125} \mathrm{Y}$ FSH for its receptor on rat testes homogenate. In vivo these antibodies probably act by blocking FSH binding to its receptor or by down-regulating the number of receptors (28).

\subsection{AUTOIMMUNITY TO TRANSFERRIN RECEPTORS}

A patient with a severe acquired iron-deficiency anemia had circulating antibodies against the transferrin receptor (30). The diagnosis was made on the basis of a microcytic anemia, increased serum iron levels and normal transferrin concentration. The bone marrow had no stainable iron. Erythroid precursors could be stained by fluorescent mouse anti human IgM. Antibodies against the transferrin receptor were demonstrated by these assays. The serum contained an antibody that reduced the uptake of radiolabeled iron by erythroleukemia cells in vitro. The serum also inhibited the binding of a fluorescent labeled monoclonal antibody against transferrin receptor. An IgM fraction of the patient's serum immunoprecipitated the human transferrin receptor. This autoantibody was capable of down-regulating the number of transferrin receptors. A complete clinical and hematological remission occurred after treatment with azathioprine and prednisone.

\subsection{AUTOIMMUNITY TO OTHER RECEPTORS}

Several endocrine diseases might be induced by antireceptor antibodies. Doniach et al. have found antibodies of the surface of gastric parietal cells in sera of patients with pernicious anemia. These antibody inhibit the production of $\mathrm{HCl}$ by parietal cells (26). These inhibitory effects on parietal cells could be responsible for the absence of intrinsic factor secretion required for vitamin $\mathrm{B} 12$ resorption. In patients with pseudohypoparathyroidism in which features of hypoparathyroidism exist with normal or raised levels of parathormone a circulating factor has been identified which inhibits the biological action of parathormone in a cytochemical bioassay system. These inhibitory factors might also be antibodies which block the renal receptor for parathormone or might be responsible for the deficient receptor-cyclase coupling activity in these patients (83).

Patients with immunodeficiency, such as acquired agammaglobulinemia could also have anti-antibodies against $B$ cell receptors. Experimentally a total ablation of $B$ cells resulting in agammaglobulinemia can be induced by the administration of antisera to the $\mu$ chain of IgM to newborn animals (84). Depending upon the heavy chain specificity of these antibodies selective immunoglobulin deficiency could occur. Naturally oc- 
curring anti-idiotypic antibodies are present in immune complexes in patients with $\operatorname{IgA}$ deficiency (85).

\subsection{CONCEPTS ON AUTOIMMUNITY APPLIED TO ANTI-RECEPTOR DISEASES}

Autoimmunity sensu strictu defines the termination of unresponsiveness to self antigens. This can be induced in two ways: by the loss of specific unresponsiveness (tolerance) or by the development of a primary immune response to an autoantigen. The nature of this autoantigen i.e. soluble or membrane associated antigens and its concentration in the microenvironment, may determine largely which mechanism is operational (86). Induction of B cell tolerance requires a $100-1000$ fold higher concentration of an antigen compared to the concentration necessary to induce $T$ cell tolerance. Some autoantigens e.g. albumin which circulates in large quantities in the extracellular fluid induce both $\mathrm{T}$ and $\mathrm{B}$ cell tolerance. Thyroglobulin, an autoantigen which is present in small concentrations in the extra-cellular fluid $(87,88)$ induces no $\mathrm{B}$ cell tolerance and a partial $\mathrm{T}$ cell tolerance. Acetylcholine receptors are probably not circulating in the extracellular fluid as freely circulating glycoproteins since they are internalized after they have been incorporated in the lipid bilayer of the cell membrane (89). Therefore tolerance against these membrane receptors probably does not exist and autoimmunity against these cell membrane components is the result of a primary immune reaction against these receptors. In chapter III we will present evidence for the absence of tolerance against self AChRs.

Another important question is how a primary immune response against cell membrane receptor, specifically $\mathrm{AChR}$, starts. Several hypotheses have been put forward.

Hypothesis A: The Thymus.

Wekerle et al. proposed that the primary sensitization against AChR occurs in the thymus (90). They cultured thymic epithelial cells expressing AChR in culture. These cells differentiated into myoid cells and might sensitize $T$ cells. The thymus could participate in the pathogenesis of the disease in two genetically controlled steps. A first set of genes would control the susceptibility to signals inducing myogenesis and the expression of AChR. In murine models this hypothesis has been confirmed (90). A second set of genes probably encoded within the major histocompatibility locus would control the level of responsiveness against self-AChR in the thymus. The thymus is also the site were $T$ cells acquire the capacity to recognize the self-MHC determinants (91). This model proposed by $\mathbf{H}$. Wekerle may have clinical implications. Indeed, a particular feature of $\mathrm{MG}$ are the thymic abnormalities e.g. follicular hyperplasie (germinal centres) and thymoma. Germinal centres occur in 47-81\% of these MG patients in whom thymectomy is performed (reviewed in 92). Germinal centres are sites of Bmemory cells and may develop in sites of chronic antigenic stimulation. It is tempting to speculate that the primary sensitization against AChR occurs in the thymus since this 
organ contains both the autoantigen - expressed on thymic epithelial (93) and thymic muscle cells (94) - and the antigen reactive cells. These speculations are substantiated by the isolation of two populations of lymphocytes from the MG thymus. The first population contains $B$ cells that spontaneously secrete anti-AChR antibodies (95) and the second population contains a $T$ helper cel subset that enhances the anti-AChR autoantibody production of peripheral blood lymphocytes of MG patients (96). These thymic abnormalities are also observed in other autoimmune diseases including thyrotoxicosis, rheumatoid arthritis and systemic lupus erythematodes (reviewed in 92). A second thymic abnormality associated with $M G$ are epitheloid tumors of the thymus (reviewed in 92). The immunopathological mechanisms that relate these thymic tumors called thymomas to MG is not entirely clear. Thymic epithelial cells secrete a number of immunological active factors such as "facteur thymique serique" which might stimulate the immune system to produce autoantibodies to $\mathrm{AChR}$. The specifity of the immune reaction to AChR might be related to the presence of the autoantigen within the thymus. Other diseases including pure red cell anaemia and hypogammaglobulinemia are associated with thymomas. Other immunological abnormalities reported in thymoma patients are the presence of antibodies to striated muscle and antinuclear antibodies (98).

\section{Hypothesis B: MHC.}

A second hypothesis applicable to autoimmune receptor disease is that of an aberrant expression of MHC class II (la-like) antigens on cell membrane of non-immune cells. $T$ cells interact with antigens when presented together with Ia antigens. An interesting finding in this respect was the demonstration of HLA-DR antigens (Ia antigen) on thyroid epithelial cells of patients with Graves' disease, an other typical antireceptor autoimmune disease (99). This aberrant expression of HLA-DR antigens on epithelial cells could enable these cells to present autoantigens to non-tolerant $T$ and $B$ cells. The expression of Ia antigens could be induced by interferons or other local factors (100). This hypothesis links autoimmunity to viral infection, a relation that was frequently suspected but difficult to prove.

\section{Hypothesis C: Idiotype mimicry.}

A third mechanism by which autoantibodies would be induced is by idiotype mimicry of autoantigen in the absence of antigen (fig. 1). Anti-idiotypic antibodies directed at anti-hormone antibodies can mimic hormone action by acting an internal image of the site reactive with the receptor for that hormone. Anti-hormone antibodies (ab 1) elicited spontaneously or by active immunization of experimental animals, induce antiidiotypic antibodies ( $a b$ 2) which in turn induce anti-anti-idiotypic antibodies ( $a b 3$ ) (fig. 1). The antibody combining site of $a b 2$ is the internal image of the hormone and may therefore mimic the hormone action on the receptor. Antibody 3 resembles antibody 1 and is able to bind to the hormone. The "internal image" hypothesis has been tested in several systems. Anti-idiotypic antibodies against insulin antibodies interact 


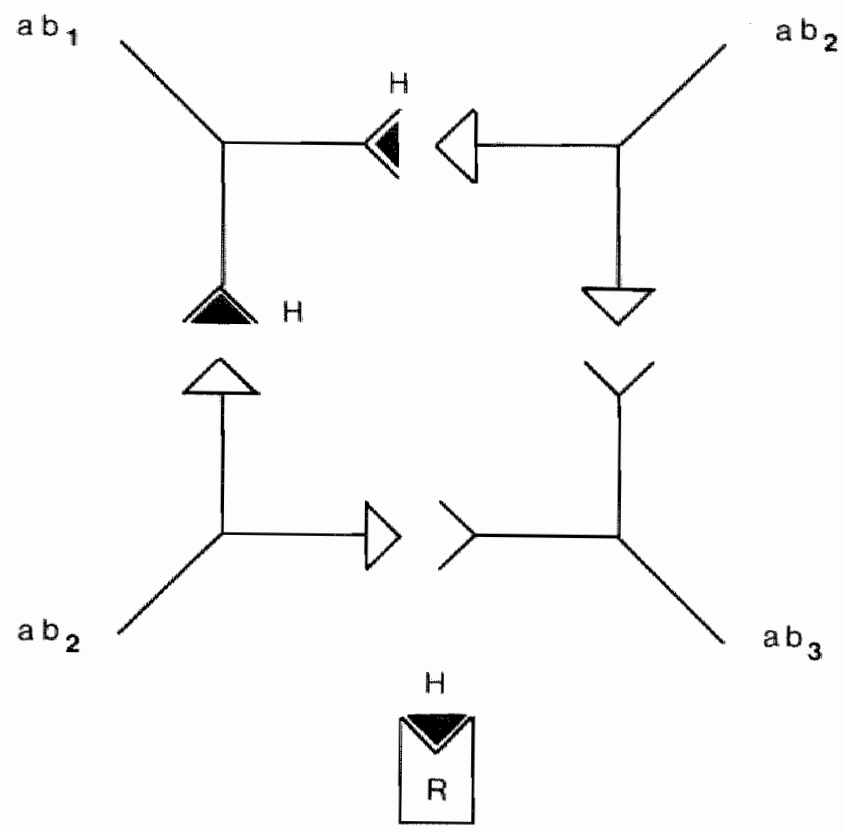

Fig. 1 Interacting components of an idiotype - anti-idiotype network involving hormones $(\mathrm{H})$, receptors ( $R$ ) and antibodies $\left(a_{1} b_{1}, a_{2}, a_{3}\right)$. Antibodies to the hormone ( $\left.\left.a_{1}\right)_{1}\right)$ induce antiidiotype antibodies which display binding sites similar to the hormone. Anti-anti-idiotype antibodies (aba) direct against abs will be able to bind to the hormone.

with insulin receptors and mimic insulin action. Similarly anti-idiotypic antibodies against-adrenergic ligands, thyrotropin, retinol-binding proteins, formyl peptide chemoattractant interact with the receptors for their respective ligands (reviewed in 101). This system is also relevant for autoimmune diseases. Anti-idiotypic antibodies prepared against the acetylcholine analogue $B$ is $Q$, interact with rat and Torpedo AChR $(102,103)$. In vivo, these anti-idiotypic antibodies block the AChR and cause myasthenia gravis. Some authors have criticized this system because of its artificial nature. Anti-hormone antibodies, however, occur spontaneously. A larger number of patients with autoimmune thyroiditis have anti-thyroid hormone antibodies (104). 


\section{References}

1. Langley JN. On the reaction of cells and nerve-endings to certain poisons, chiefly as regards the reaction of striated muscle tio nicotine and curare. J. Physiol. 33: 374-415, 1905.

2. Ehrlich P. Chemotherapeutics: scientific principles, methods and results. Lancet ii: $445-451,1913$.

3. Robison GA, Butcher RW and Sutherland EW. Cycli AMP. New York, Academic Press, 1971.

4. Ross EM and Gilman AG. Biochemical properties of hormone-sensitive adenylate cyclase. Ann. Rev. Biochem. 49: 533-565, 1980 .

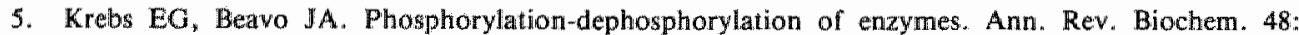
$923-959,1979$.

6. Katz $\mathbf{B}$ and Miledi $\mathrm{R}$. The statistical nature of the acetylcholine potential and its molecular components. J. Physiol. (London) 224: 665-699, 1972.

7. Jerne NK. Towardis a network theory of the immune system. An. d'Immunol. (Paris) 125C: 373, 1974.

8. Cheng $\mathrm{H}-\mathrm{L}$, Blattner $\mathrm{F} R$, Fitzmaurice $\mathrm{L}_{*}$ Mushinski JF and Tucker PW. Structure of genes for membrane and secreted murine IgD heavy chains. Nature 296: 410-415, 1982 .

9. Karlin $A$ and Cowburn. The affinity-labeling of partially purified acetylcholine receptor from electric thissue of Electrophorus. Proc. Natl.Acad.Sci. USA 70: 3636-3640, 1973.

10. Roitt IM, Doniach $D$, Campbell PN and Hudson RV. Autoantibodies in Hashimoto's disease (lymphadenoid goitre), Lancet ii: 820-821, 1956.

11. Rose NR and Witebsky E. Studies on organ specificity V. Changes in the thyroid glands of rabbits. following active immunization with rabbit thyroid extracts. J. Immunol. 76: 417-427, 1956.

12. Rose NR. Endocrine diseases. In: Basic and Clinical Immunology. Fudenberg HH et al. Eds., Lange Medical Publications, 2nd ed., p. 628-642.

13. Simpson JA. Myasthenia gravis: a new hypothesis. Scott.Med.J. 5: 419-436, 1960.

14. Nastuk WL, Plescia OJ, Osserman KE. Changes in serum complement activity in patients with myasthenia gravis. Proc.Soc.Exp.Biology Med. 105: 177-184, 1960.

15. Carnegie PR. Properties, structure and possible neuroreceptor role of the encephalitogenic protein of human brain. Nature (London) 229: 25-28, 1971.

16. Lennon VA and Carnegie PR. Immunopharmacological disease: a break of tolerance to receptor sites. Lancet i: 630-633, 1971 .

17. Patrick $J$ and Lindstrom $J$. Autoimmune response to acetylcholine receptor. Science 180: 871-872, 1973.

18. Lennon VA, Lindstrom JM and Seybold ME. Experimental autoimmune myasthenia gravis in rats and guinea pigs. J. Exp.Med. 141: 1365-1375, 1975.

19. Lindstrom J. An assay for antibodies to human acetylcholine receptor in serum from patients with myasthenia gravis. Clin. Immunol. and Immunopathol. 7: 36-43, 1977.

20. Adarns DD and Kennedy TH. Association of long acting thyroid stimulator with the gamma globulin fraction of serum. Proc.Uniw. Otago Med. Sch. 40:6-7, 1962.

21. Drexhage HA, Bottazzo GF, Doniach D, Bitensky $\mathbb{L}$ and Chayen J. Evidence for thyroid-growthstimulating immunoglobulins in some goitrous thyroid diseases. Lancet ii: 287-292, 1980.

22. Drexhage H, Bottazzo G, Bitensky L, Chayen J and Doniach D. Thyroid growth-blocking antibodies. in primary myxoedema. Nature 289: $594-596,1981$.

23. Flier JS, Kahn CR, Roth $\mathbb{J}$ and Bar RS. Antibodies that impair insulin receptor binding in an unusual diabetic syndrome with severe insulin resistance. Science 190: 63-65, 1975 .

24. Tayllor SI, Grunberger $\mathrm{G}$, Marcus-Sanuels $\mathrm{B}$, Underhill $\mathrm{LH}$, Dons RF, Ryan J, Roddam RF, Rupe CE and Gorden P. Hypoglycemia associated with antibodies to the insulin receptor. N. Engl.J.Med.. 307: $1422-1426,1982$.

25. Jüppner H, Bialasiewicz AA and Hesh RD. Autoantibodies to parathormone receptor. Lancet ii: $1222-1224,1978$.

26. Loveridge N, Bitensky L, Chayen J, Hausamen JU, Fisher JM, Taylor KB, Gardener JD, Bottazzo GS and Doniach D. Inhibition of parietal cell function by human gammaglobulin containing gastric cell antibody. Clin. Exp. Immunol. 41: 264-270, 1980.

27. Venter JG, Fraser CM and Harrison LC. Autoantibodies to $\beta 2$-adrenergic receptors: A possible cause of adrenergic hyporesponsiveness in allergic rhinitis and asthma. Science 207: 1361-1362, 1980.

28. Chiauzzi V, Cigorraga $S$, Escobar ME, Rivarola MA and Charreau EH. Inhibition of follicle- 
stimulating hormone receptor binding by circulating immunoglobulins. J. Clin. Endocrinol. Metab. 54: $1221-1228,1982$.

29. Larrick $J W$ and Hyman ES. Acquired iron-deficiency anaemia caused by an antibody angainst the transferrin receptor. N. Engl.J.Med. 311: 214-218, 1984.

30. Hyman ES. Acquired iron-deficiency anaemia due to impaired iron transport. Lancet i: $91-95,1983$.

31. Smith BR and Hall R. Thyroid-stimulating immunoglobulins in Graves' disease. Lancet ii: $427-431,1974$.

32. Dijane J, Houdebine LM and Kelly PA. Prolactin-like activity of anti-prolactin receptor antibodies on casein and DNA synthesis in the mammary gland. Proc.natl.Acad.Sci. USA 78: 7445-7448, 1981.

33. Schreiber AB, Lax I, Yarden $Y$, Eshhar Z and Schlessinger $J$. Monocional antibodies against receptor for epidermal growth factor induce early and delayed effects of epidermal growth factor. Proc. Natl. Acad. Sci. USA 78: 7535-7539, 1981.

34. Goldflam S. Ueber einen scheinbar heilbaren bulbär paralytischen Symptomencomplex mit Beteiligung der Extremitäten. Deutsches Zeitschrift für Nervenheilkunde 4: 312-352, 1883.

35. Engel AG. Myasthenia gravis. In: Handbook of Clinical Neurology. Ed, by PJ Vinken and GW Bruyn. Amsterdam, North-Holland, 1979, vol. 41, part II, p. 95-145.

36. Oosterthuis HJGH. "Myasthenia Gravis" in clinical neurology and neurosurgery monographs, vol. 5. GH Glaser et al., Eds. Churchill Livingstone, 1984, p. 21-28.

37. Oosterhuis HJGH. "Myasthenia Gravis" in clinical neurology and neurosurgery monographs, vol. 5. GH Glaser et al., Eds. Churchill Livingstone, 1984, p. 28.

38. Behan PO, Simpson JA and Dick H. Immune response genes in myasthenia gravis. Lancet ii: $1033,1973$.

39. Feltkamp TEW, vd Berg-Loonen PM, Nijenhujs LE, Engelfriet CP, van Rossum AL, van Loghem, JJ and Oosterhuis HJ. Myasthenia gravis, autoantibodies and HLA antigens. Brit. Med. J. 1: 131-133, 1974.

40. Fritze D, Herrmann $C, N a e i m F_{n}$ Smith GS and Walford RL. HL-A antigens in myasthenia gravis. Lancet i: $240-242,1974$.

41. Hammarstroem L, Smith E, Moeller E, Franksson C, Matell G, von Reis G. Myasthenia gravis : studies on HL-A antigens and lymphocyte subpopulations in patients with myasthenia gravis. Clin. Exp. Immunol. 21: 202-215, 1975 .

42. Oosterhuis HJGH, Feltkamp TEW, van Rossum AL, van den Berg-Loonen PM, Nijenhuis LE. HL-A antigens, autoantibody production and associated diseases in thymoma patients with and without myasthenia gravis. Ann. NY Acad. Sci 274: 468-474, 1976.

43. Pirskanen $\mathbb{R}$. Genetic associations between myasthenia gravis and the HL-A system. J. Neurol. Neurosurg. Psychiatry 39: 23-33, 1976.

44. Kaakinen A, Pirsikanen R, Tilikainen A. LD antigens associated with HL-A8 and myasthenia gravis. Tissue Antigens 6: 175-182, 1975.

45. Gross WL, Krueger J, Groeschel-Stewart U, Friedrich H, Kunze K. Studies on HLA antigens and cellular and humoral autoimmune phenomena in patients with myasthenia gravis. Clin. Exp. Immunol. 27: 48-54, 1977 .

46. Compston DAS, Vincent A, Newson-Davis J, Batchelor JR. Clinical, pathological, HLA antigen and immunological ewidence for disease heterogeneity in myasthenia gravis. Brain 103: 579-601, 1980.

47. Keesey J, Naiem F, Lindstrom JM and Roe D. Acetylcholine receptor antibody titer and HLA-B8 antigen in myasthenia gravis. Archives of Neurology 39: 73-77, 1982.

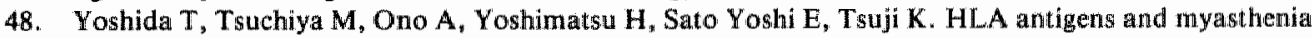
gravis in Japan. J. of Neurol. Sc. 32: 195-201, 1977.

49. Nakao $\mathrm{Y}$, Matsumoto $\mathrm{H}$, Miyazaki $T$, Nishitani $\mathrm{H}$, Ota $\mathrm{K}$, Fujita $T$, Tsuji $\mathrm{K}$. Gm allotypes in myasthenia grawis. Lancet i: $677-680,1980$.

50. Oosterhuis HJGH. Myasthenia gravis, In: Clinical Neurology and Neurosurgery monographs, vol. 5. Glaser GH et al., Eds. Churchill Livingstone, 1984, p. 122.

51. Lindstrom JM, Seybold ME, Lennon VA, Whittingham S, Duane D. Anibody to acetylcholine receptor in myasthenia gravis. Prevalance, clinical correlates and diagnostic value. Neurology 26: 1054-1059, 1976.

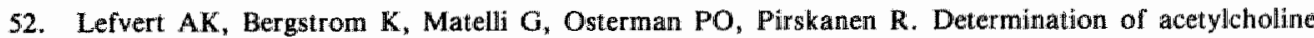
receptor antibody in myasthenia gravis: clinical usefulness and pathogenic implications. J. Neurol. Neurosurg. Psychiatry 41: 394-403, 1978. 
53. Limburg PC, Hummel E, The TH, Oasterhuis HJGH. Anti acetylcholine receptor antibodies is myasthenia grawis. I Their relation to clinical state and the effect of therapy. $\mathbf{J}$. Neurol. Sc. 58: 357-370, 1983.

54. Keesey J, Lindstrom JM, Cokely $\mathrm{H}$, Herrmann C. Anti acetylcholine receptor antibody in neonatal myasthenia gravis. N. Eng. J. of Med. 296: 55, 1977.

55. Lefvert $A k$, Osterman PO. Newborn infants to myasthenic mothers: a clinical study and an investigation of acetylcholine receptor antibodies in 17 children. Neurology 2: 133-138, 1983.

56. Ohta $M$, Matsubara $\mathbb{F}$, Hayashi $K$, Nakao $K$, Nishitani $K$. Acetylcholine receptor antibodies in infants and mothers with myasthenia gravis. Neurology 31: 1019-1022, 1981 .

57. Namba $T$, Brown SB, Grob D. Neonatal myasthenia gravis : report of two cases and review of the literature. Pediatrics. 45: 488-504, 1970.

58. Vincent A. Immunology of acetylcholine receptors in relation to myasthenia gravis. Phys. Rev. 60: $757-824,1980$.

59. Conti-Tronconi BM, Raftery MA. The nicotinic cholinergic receptor : correlation of molecular structure with functional properties. Ann. Rev. Biochem. 51: 491-530, 1982.

60. Lindstrom J. Autoimmune response to acetylcholine receptors in myasthenia gravis and its animal model. Adv. Immunol. 27: 1-50, 1979.

61. Engel AG, Tsuwimata M, Lindstrom J, Lennon $Y$. The motor endplate in myasthenia gravis and in experimental autoimmune myasthenia gravis. A quantitative ultrastructural study. Ann. NY Acad. Sci. 274: 60-79, 1976 .

62. Engel AG, Lambert EH, Howard FM. Immune complexes (IgG and C3) at the motor endplate in myasthenia gravis. Ultrastructural and light microscopic localisation and electrophysiological correlations. Mayo Clin. Proc. 52: 267-280, 1977.

63. Sahashi $K$, Engel $A G$, Lindstrom JM, Lambert EM, Lennon VA. Ultrastructural localilsation of immune complexes (IgG and $\mathrm{C} 3$ ) at the endplate in experimental autoimmune myasthenia gravis. $J$. Neuropath. Exp. Neurol. 37: 212-223, 1978.

64. Sahashi K, Engel AG, Lambert EH, Howard FM. Ultrastructural localization of the terminal and lytic ninth complement component $(\mathrm{C} 9)$ at the motor endplate in myasthenia gravis. J. Neuropathol. Exp. Neurol. 39: 160-172, 1980.

65. Toyka KV, Drachman DB, Pestronk A, Kao I. Myasthenia gravis: passive transfer from man to mouse. Science 190: 397-399, 1975.

66. Adams D, Purves H. Abnormal responses in the assay of thyrotropin. University of Otago Medical School Proceedings 34: 11-12, 1956.

67. Kriss JP, Pleshakov V, Chien JR. Isolation and idenfication of the long acting thyroid stimulator and its relation to hyperthyroidism and circumscribed pretibial myxoedema. $J$. Clin. Endocrinol. Metab. 24: 1005-1028, 1964,

68. Adams DD, Kennedy TH. Occurrence in thyrotoxicosis of a gammaglobulin which protects LATS from neutralization by an extract of thyroid gland. J. Clin. Endocrinol. Metab. 27: 173-177, 1967.

69. Adams DD, Fastier FN, Howie JB, Kennedy TH, Kilpatrick JA, Stewart RDH. Stimulation of the human thyroid by infusions of plasma containing LATS protector. J. Clin. Endocrinol. Metab. 39: 826-830, 1974.

70. Fenzi $\mathrm{G}$, Mariotti S, Bartalena L, Degroot LJ. Thyroid stimulating immunoglobulins. In "Special topics in endocrinology and metabolism", Cohen MP and Foa PP, Eds. Vol, 2, New York, Alan Liss, 1981. pp. 44-73.

71. Bech K. Immunological aspects of Graves' disease and importance of thyroid stimulating immunoglobulins. Acta Endocrinol. (Suppl) 254: 3-38, 1983.

72. Orgiazzi J, Williams D, Chopra I, Solomon D. Human thyroid adenyl cyclase-stimulating activity. Immunoglobulin $G$ of patients with Graves' disease. J. Clin. Endocrinol. Metab. 42: 341-354, 1976.

73. De Baets M, Elewaut A, Dacremont G, Vermeulen A. Autoantibodies to the thyrotropin receptor and their significance in autoimmune thyroid disease in Immunologic Analysis: Recent progress in diagnostic laboratory. Nakamura RM, Dito WR, Tucker III ES, Eds. Masson, p. 37-51, 1982. Masson 37-51, 1982.

74. Ong $M_{x}$ Malkin DG, Malkin A. Thyroid function in rabbits immunized with bovine thyroid plasma membranes. Ann. Endocrinol. 38: 1A, 1978.

75. Kido A, Okita N, Row VV, Volpe R. Immunological aspects of Graves' and Hashimoto"s disease. Metabolism 29:80-99, 1980. 
76. Zakarija $\mathrm{M}$. The thyroid stimulating antibody of Graves' disease : evidence for restricted heterogeneity. Hormone Research 13:11-12, 1980.

77. Karlsson FA, van Obberghen $\mathbb{E}$, Grunfeld $C$ and $K a h n, C R$. Desensitization of the insulin receptor at an early post receptor step by prolonged exposure to anti-receptor antibody. Proc. Natl. Acad. Sci. USA 76: 809-813, 1979.

78. Harrison LC. Autoantibodies to hormone receptors. Springer Seminars in immmunopathology 5 : $447-462,1982$.

79. Harrison LC, Flier IS, Karlsson FA, Kahn CR. Immunoprecipitation of the insulin receptor : a sen. sitive assay for receptor antibodies and a specific technique for receptor purification. J. Clin. Endiocrinol. Metab. 48:59-65, 1979.

80. Melez K, Harrison LC, Gilliam JN, Steinberg A.D. Diabetes is associated with antonmmunity in the New Zealand obese (NZO) mouse. Diabetes 29: 835-840, 1980.

81. Fraser $\mathrm{CM}$, Venter $\mathrm{JC}$, Kaliner $\mathrm{M}$. Autonomic abnormalities and autoantibodies to $/$-adrenergic receptors. N. Eng. J. Med. 305: 1165-1170, 1981.

82. Szentivanyi $\mathbf{A}$. The beta-adrenergic theory of the atopic abnormality in bronchial asthma. J. Allergy 42: $203-232,1968$.

83. Loveridge N, Fischer JA, Nagant de Deuxchaisnes C. Dambacher MA ${ }_{*}$ Tschopp F, Werder E, Devogelaer JP, De Meyer R, Bitensky L and Chaeyn. Inhibition of cyctochemical bioactivity of parathoid hormone by plasma in pseudo 'hypoparathyroidism type $\mathrm{I}_{\text {. }} \mathrm{J}$. Clin. Endocrin. Metabol, 54: 1274-1275. 1981 .

84. Kincade PW, Lawton AR, Bockman DE, Cooper MD. Suppression of immunoglobulin G synthesis as a result of antibody-mediated suppression of irnmunoglobulin $M$ synthesis in chickens. Proc. Nath. Acad. Sci. USA 67: 1918-1925, 1970.

85. Cunningham-Rundles C. Naturally occuring autologous anti-idiotypic antibodies. Participation in immune complex formation by selective IgA deficiency.J. Exp. Medl, 155: 711-719, 1982.

86. Weigle WO. Analysis of autoimmunity through experimental models of thyroiditis and allergic encephalomyelitis "Adv. Immunollogy 30: 159-273, 1980.

87. van Herle AJ, Vassart G, Dumont JF. Control of thyroglobulin synthesis and secretion. New Engl. J. Med. 301: 239-249 and 307-314, 1979.

88. De Baets M, Janssens AM, Romball C, Weigle WO. A radioimmunoassay for murine thyroglobulin in serum : age-related increase of serum thyroglobulin levels in AKR/J mice. Endocrinol. 112: 1788-1795, 1983.

89. Pumplin DW, Fambrough DM. Turnover of acetylcholine receptors in skeletal muscle. Ann. Rev. Physiol. 44: 319-335, 1982.

90. Wekerle $H$, Hohlfeld R, Ketelsen UP, Kaiden JR, Kalies I. Thymic myogenesis, T-lymphocytes and the pathogenesis of myasthenia gravis. Ann. NY Acad. Sic. 377: 455-476, 1981.

91. Zinkernagel RM, Callahan GN, Althage $A$, Cooper $S$, KJein PA and Klein J. On the thymus in the differentiation of "H-2 recognition" by T-cells : evidence for dual recognition. J. Exp. Med. 147: $882-896,1978$.

92. Oosterhuis HJGH. Myasthenia gravis. In: Clinical Neurology and Neurosurgery monographs, wol. 5. Claser GH et al., Eds. p \$1-76, 1984.

93. Engel WK, Trotter JL, McFarlin DE, McKintosh CL. Thymic epithelial cells contains acetylcholine receptor. Lancet i: $1310-1311,1977$.

94. Kao 1, Drachman DB. Thymic muscle cells bear acetylcholine receptors : possible relation to myasthenia gravis. Science 195: 74-75, 1977.

95. Vincent A, Scadding GK, Thomas HC, Newsom-Davis J. In-vitro synthesis of anti-acetylcholinereceptor antibody by thymic lymphocytes in myasthenia gravis. Lancet i: $305-307,1978$.

96. Newsom-Davis J, Willcox $N$, Calder $L$. Thymus cells in myasthenia gravis selectiwely enhance production of anti-acetylcholine-receptor antibody by autologous blood lymphocytes. N. Engl. J. Med. 305: $1313-1318,1982$.

97. Jambon B, Montagne P, Bene MC, Brayer MP, Faure G, Duheille J. Immunohistologic localization of "facteur thymique serique" (FTS) in human thymic eptihelium. J. Immunol. 127: 2055-2059, 1981.

98. Oosterhuis HJGH, Feltkamp TE, wan Rossum AL, wan den Berg-Loonen PM, Nijenhuis LE. HL-A antigens, autoantibody production and associated diseases in thymoma patiets, with and without myasthenia gravis. Ann. NY Acad. Sc. 274: 468-474, 1976. 
99. Hanafusa T, Chiowato L, Doniach D, Pujol-Borrell $\mathbb{R}$, Russell R, Bottazzo GF. Aberrant expression on HLA-DR antigen on thyrocytes in Graves' disease : relevance for autoimmunity. Lancet ï: $1111-1115,1983$.

100. Bottazzo GF, Pujol-Borrell R, Hanafusa $T$, Feldman M. Rolle of aberrant HLA-DR expression and antigen presentation in induction of endocrine autoimmunity. Lancet ii: $1115-1118,1983$.

101. Strosberg AD. Antidiotype and anti-hormone receptor antibodies. Springer Seminars in Immunopathol. 6: 67.78, 1983.

102. Wasserman NH, Penn AS, Freimuth PI, Treptow N, Wentzel S, Cleveland WL and Erlanger BF. Antiidiotypic route of anti-acetylcholine receptor antibodies and experimental myasthenia gravis. Proc.Natl.Acad.Sci. USA 79:4810-4814, 1982.

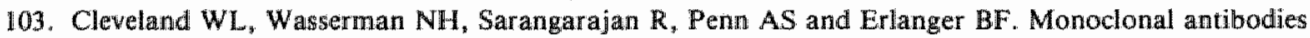
to the acetylcholine receptor by a nomally functioning auto-anti-idiotypic mechanism. Nature 305 : $56-57,1983$.

104. Premachandra BN and Blumenthal HT. Abnormal binding of thyroid hormone in sera from patients with Hashimoto's disease. 1. Clin. Endocrinol. 27: 931-936, 1967. 


\section{CHAPTER II}

\section{The experimental autoimmune myasthenia gravis animal model.}

\subsection{INTRODUCTION}

J. Simpson, a neurologist, suggested that myasthenia gravis was caused by autoantibodies directed against proteins at postsynaptic sites (1). His idea was picked up by E. Lennox who passed Simpson"s paper on to his graduate student, the biochemist, J. Lindstrom (2). Lindstrom and J. Patrick succeeded in identifying AChR biochemically but not by means of using human anti AchR antibodies although this was implicit in Simpson's hypothesis.

Progress in AChR isolation was made possible by two observations. First, the electric organs of the electric eel (electrophorus electricus) and electric ray (Torpedo Californica) were found to be rich sources of AChR (3); second, some snake venom toxins with curare-like activity were shown to bind specifically to AChR (4).

Using these observations Patrick and Lindstrom purified AChR from solubilized electric organs on snake-toxin-agarose columns. AChRs werd eluted from the columns by means of an acetylcholine antagonist. In order to test if this purified receptor contained the physiologically active AChR they decided to immunize rabbits with this AChR preparation. The immunized animals became paralyzed and died. This observation brought Simpson's theory that MG was an autoimmune disease, back to their mind (2).

\subsection{THE AUTOANTIGEN: The acetylcholine receptor (AChR)}

The study of organ specific autoimmune diseases necessitates a detailled study of autoantigens and their role in the induction and maintenance of the disease. The regulatory role of autoantigens in autoimmune disease had been demonstrated by 1 . Roitt and coworkers who showed that neonatal removal of an autoantigen such as thyroglobulin prevented the production of autoantibodies to thyroglobulin in the obese chicken strain (5).

The detailed structure of the nicotinic AChR receptors has been elucidated by combined efforts of biochemists, using recombinant DNA technology and immunologists using monoclonal antibodies. Acetylcholine receptors from the electric organ of Torpedo Californica are composed of four subunits associated in the molar ratio: 2- $\alpha, \beta, \gamma$ and $\delta$. The apparent molecular weights of these subunits is $38,000,49,000,57,000$ and 64,000 for $\alpha, \beta, \gamma$ and $\delta$ subunits respectively $(6,7)$. All four subunits are strongly associated by hydrophobic bonds and compose a single AChR molecule with a central ion channel. This channel opens upon interaction of an acetylcholine molecule with each $\alpha$-subunit. 


\subsubsection{Biochemistry of acetylcholine receptors}

The AChR is a glycoprotein that spans the cell membrane. It can be isolated easily from the electric organs of electric fish (Torpedo californica, and other Torpedo species and electrophorus electricus), mammalian and human muscle (8). The critical observation which allowed receptor purification was the discovery that $\alpha$-bungarotoxin ( $\alpha$-BGT) present in venoms of cobras and kraits (Naja Naja siamensis) toxin binds with high affinity and specificity to the acetylcholine binding site or a closely adjacent site (4). Solubilized extracts of electric organs were passed over a column containing Cobra toxin linked to agarose beads. After washing away all contaminants, AChR was eluted with acetylcholine analogues such as carbamylcholine or benzoquinonium $(9,10)$. The amino acid sequence of AChRs purified from electric organs of rays and eels, has been determined by partial amino-terminal amino acid sequencing (13) and by recombinant DNA technology $(13,14)$. There is a $35-50 \%$ amino acid sequence homology between the four subunits, indicating that the 4 subunits probably are derived by reduplication from one ancestral gene (13). This homology is only present at the aminoterminal two-thirds, whereas the carboxy terminal one-third is rather divergent (11-13). Most of this carboxy terminal part is embedded in the cell membrane or expressed at its cytoplasmic side. Each subunit is glycosylated presumably on its extracellular surface and contains small amounts of galactose, mannose, glucose and galactosamine $(14,15)$. These carbohydrates may play a role in folding newly synthesized peptides to form a conformation compatible with ion channel function (16).

Acetylcholine receptors have also been purified from mammalian muscle including fetal bovine AChR $(17,18)$ and human AChR (19). Bovine and human AChR are structurally similar to those of Torpedo and eel electric organ. All four receptors when labeled with ${ }^{25} \mathrm{I}-\alpha$-BGT sediment at $9 \mathrm{~S}$ in linear sucrose gradients and have a MW of approximately 250.000 (17). AChR from Torpedo also exists in dimers (20). Among the $\alpha$-subunits of fetal bovine, eel and torpedo AChR a homology of $51 \%$ and $38 \%$ exists respectively (21).

\subsubsection{Acetylcholine receptor function}

The function of AChRs present at the neuromuscular junctions of striated muscle is to amplify the small current required for propagating an action potential in a myelinated nerve to the larger current necessary for the contraction of a muscle fiber. Upon binding of two acetylcholine molecules released in quanta of $10^{4}$ molecule from the nerve terminal to each $\alpha$-subunit, the ion channel opens for about $1 \mathrm{msec}$. at a conductance of about 30 pico Siemens, which corresponds to the transport of about 50.000 monovalent cations (22). Most of the acetylcholine molecules released are inactivated by acetylcholine esterase, an enzyme attached to the basement membrane located between nerve terminal (presynaptic membrane) and the muscle membrane (postsynaptic membrane) (23). Whereas activation is a rapid process, recovery from desensitization 
is a slow process, requiring minutes.

When the nerve is stimulated about 60 quanta $\left(=60 \times 10^{4} \mathrm{ACh}\right.$ molecules $)$ of acetylcholine are released at the neuromuscular endplate of human intercostal muscle (24). Normally the amount of acetylcholine released and the number of AChR activated is much larger than the minimum amount necessary for a muscle fibre contraction (23). This excess of acetylcholine released provides a safety factor, which differs among species. Rabbits and rats are very susceptible to the induction of EAMG whereas mice which have a larger safety factor are more resistant to the disease.

\subsubsection{Synthesis and destruction}

AChRs are synthetized in the rough endoplasmatic reticulum of the muscle cells, using four separate m-RNA's for each receptor subunit. The AChR is "secreted" through the Golgi apparatus and inserted in the plasmamembrane (25). Glycosylation is required for maturation of subunit structure $(16,26)$. Further maturation is necessary before the ligand binding site is operational.

AChRs at the neuromuscular junction are removed by endocytosis. Their half life is 5-7 days, in contrast to $\mathrm{AChR}$ present extrajunctionally which are removed more rapidly ( $t \frac{1}{2}=20$ hours). Cross-linking of AChR by autoantibodies, which occurs in EAMG and MG facilitates internalization with lysosomal breakdown which takes about 90 minutes (27).

\subsubsection{Antigenic anatomy of Acetylcholine receptor}

Before monoclonal antibody technology was applied to acetylcholine receptors little was known about the antigenic structure of $A c h R$ from electric fish. It was found to be an extremely potent antigen since an injection of as little as $1 \mu \mathrm{g}$ electric organ AChR incorporated in complete Freund's adjuvant (CFA) was able to induce an antibody response. Separate subunits, dissociated in sodium dodecylsulfate (SDS) are poorly immunogenic, but prolonged immunization yields antisera specific for each receptor subunit inspite of the extensive sequence homology. (Some degree of cross-reaction is detectable especially between $\gamma$ and $\delta$-subunits) (29). This suggests that most of the antigenic determinants are dependent upon the three dimensional structure of these determinants. This is also true for the main immunogenic region, a small group of determinants which were discovered with monoclonal antibodies (30). More than $50 \%$ of the antibodies in sera from patients with myasthenia gravis (31) and from animals with EAMG are directed at this region. Many other sites on $A C h R$ are immunogenic but antiAChR antibodies that cross react with $A C h R$ from other species are mainly directed at the main immunogenic region (31). This determinant consists of a continuous sequence of amino acids localized on the extracellular surface of the $\alpha$-subunit but distinct from the acetylcholine binding site (32). The MIRs on $\alpha$-subunits are oriented in such a way that an antibody bound to one $\alpha$-subunit cannot bind to another 
$\alpha$-subunit on the same receptor. Thus monoclonal antibodies to the MIR can only cross link AChR molecules (38). Cross linking of AChR induces an increase in AChR turnover, a phenomenon called antigenic modulation which is probably one of the most important immunopathological mechanisms in MG and EAMG (vide infra). Antibodies to $\beta, \gamma$ or $\delta$-subunits can only cross link to receptor molecules, since only one antigenic site is present on each AChR monomer. Monoclonal antibodies to the MIR can passively transfer EAMG whereas only few antibodies with other specificities are myasthenogenic (34). Some monoclonal antibodies against the acetylcholine binding site induce EAMG when passively transferred into normal animals (35). This acetylcholine binding site is a very small antigenic site (36) and since the ligand is phylogenetically highly conserved, the binding site must be too. For these reasons it is probably not very immunogenic and therefore not very important in the pathogenesis of EAMG.

\subsection{INDUCTION OF EXPERIMENTAL AUTOIMMUNE MYASTHENIA GRAVIS}

Experimental autoimmune myasthenia gravis (EAMG) can be induced in mammalians, birds and reptiles by the injection of purified acetylcholine receptors from electric organs incorporated in complete Freund's adjuvant (CFA) and pertussis vaccines (reviewed in 37). The animal species tested include rabbit, rat, guinea pig, goat, monkey, frogs and hens. Historically the rabbit was the first animal species used to induce EAMG $(38,39)$. With few exceptions rabbits developed flaccid paralysis one week after the second injection of $100 \mu \mathrm{g}$ Torpedo AChR given at four weeks' interval. The affected animals are unable to support their bodies, have difficulties in breathing and swallowing and usually die within 1 or 2 days from respiratory insufficiency. Anticholesterase treatment $(37 \mu \mathrm{g} / \mathrm{kg})$ produces a marked but temporary improvement (37).

Clinical symptoms and severity of disease varies widely among the species used. Monkeys developed signs characteristic of human disease including eye lid ptosis, dysphagia, facial weakness and ophthalmoplegia (40). Except for the human-like clinical signs the monkey model for EAMG is not more relevant than the rodent models for the study of the mechanisms operational in EAMG and MG and should therefore not be used for ehtical reasons. We will therefore concentrate on studies using rodents including rats and mice. Rats in contrast to mice are very susceptible to clinical signs of EAMG because rats probably have a lower neuromuscular safety factor than mice. The susceptibility to EAMG in inbred and genetically defined strains of mice is linked to the immune response genes on the major histocompatibility gene $(\mathrm{H}-2)$ and the genes coding for the allotype (IgCh locus)* $(41,42)$.

* Allotypes: aside from structural heterogeneity in the heavy chains associated with a given subclass there is a further variation within a given subclass which is called allotype. This usually involves one or two aminoacids in the peptide chain. Allotypes can be used as a genetic marker. 


\subsubsection{Experimental autoimmune myasthenia gravis in rats}

EAMG can be induced in Lewis rats by injection of $A C h \mathbb{R}$ purified from electric organs of the electric eel (27), Torpedo, or its denaturized subunits (28), fetal calf muscle (17), and syngeneic rat AChR (43). Immunization with two injections of $15 \mu \mathrm{g}$ Torpedo AChR incorporated into complete or incomplete Freund's adjuvant given at a one month interval invariably induces EAMG in all Lewis rats tested. Other strains of rats including Brown Norway, Louvain and Sprague Dawley are equally susceptible to EAMG. A single report mentioned that Wistar rats were resistant to the disease (44). This seems unlikely, since susceptible Louvain rats are also of Wistar origin.

Lewis rats immunized with additional adjuvants such as Bordetella pertussis (10 to organisms of special vaccine product of Eli Lilly \& Co) develop a biphasic illness (27). An acute, transient illness characterized by a temporary, sometimes fatal paralysis develops 7 to 10 days after immunization. About one month after the first (of two) immunizations with AChR a chronic disease develops. EAMG can be passively transferred from these animals into normal rats with small amounts of serum (200 $\mu \mathrm{l}$ of a serum with a titer of $5 \times 10^{-8} \mathrm{M}$ of anti rat AChR or $1 \mu \mathrm{g}$ of antibody) (45).

The clinical signs of EAMG are a consequence of weakness of upper limb, head and neck, and laryngeal and respiratory muscles. The animal lays his head and chest on the floor, the back is exaggeratedly humped with the thighs partially abducted. The digits of the forelimbs are flexed and fail to extend when the rat is placed on a flat surface (fig. 1A). These symptoms can be temporarily reversed by treatment of anticholinesterase drug (Prostigmine $35 \mu \mathrm{g} . / \mathrm{kg}$ ) (fig. 1A en 1B). Excessive growth of the teeth suggests impairment of masticatory muscles (fig. 1B). At the end stage of the disease chronic respiratory disease becomes manifest as loud exspiratory wheeze and brown porphyrin staining of nasal secretion and tears. Animals with chronic respiratory disease also have a brown discoloration of the neck that is caused by wiping off their paws (27). The rats finally die from malnutrition. The endstage of disease can be delayed by trimming their teeth and placing soft food within easy reach of the animals.

\subsubsection{Experimental autoimmune myasthenia gravis in mice}

Mice like rats, develop EAMG upon injection with $A C h R$ from electric organ. One to two weeks after a second injection of $15 \mu \mathrm{g} \mathrm{AChR}$ in CFA mice develop muscular weakness. In order to distinguish myasthenic from non-myasthenic animals behavioral and pharmacological tests are necessary. These tests include forced excercise (e.g. forced run, inverted hang, free swim) and injection of low doses d-tubocurarine which induce paralysis in subclinical myasthenia (41).

The susceptibility to EAMG in mice is genetically determined. In some strains such as C57Bl/6, SJL and AKR 50-70\% of the mice develop EAMG; while in Balb/cke, SWR/I and $\mathrm{C} 3 \mathrm{H} / \mathrm{HC}$ only $3-15 \%$ of the mice become paralyzed. These differences in 

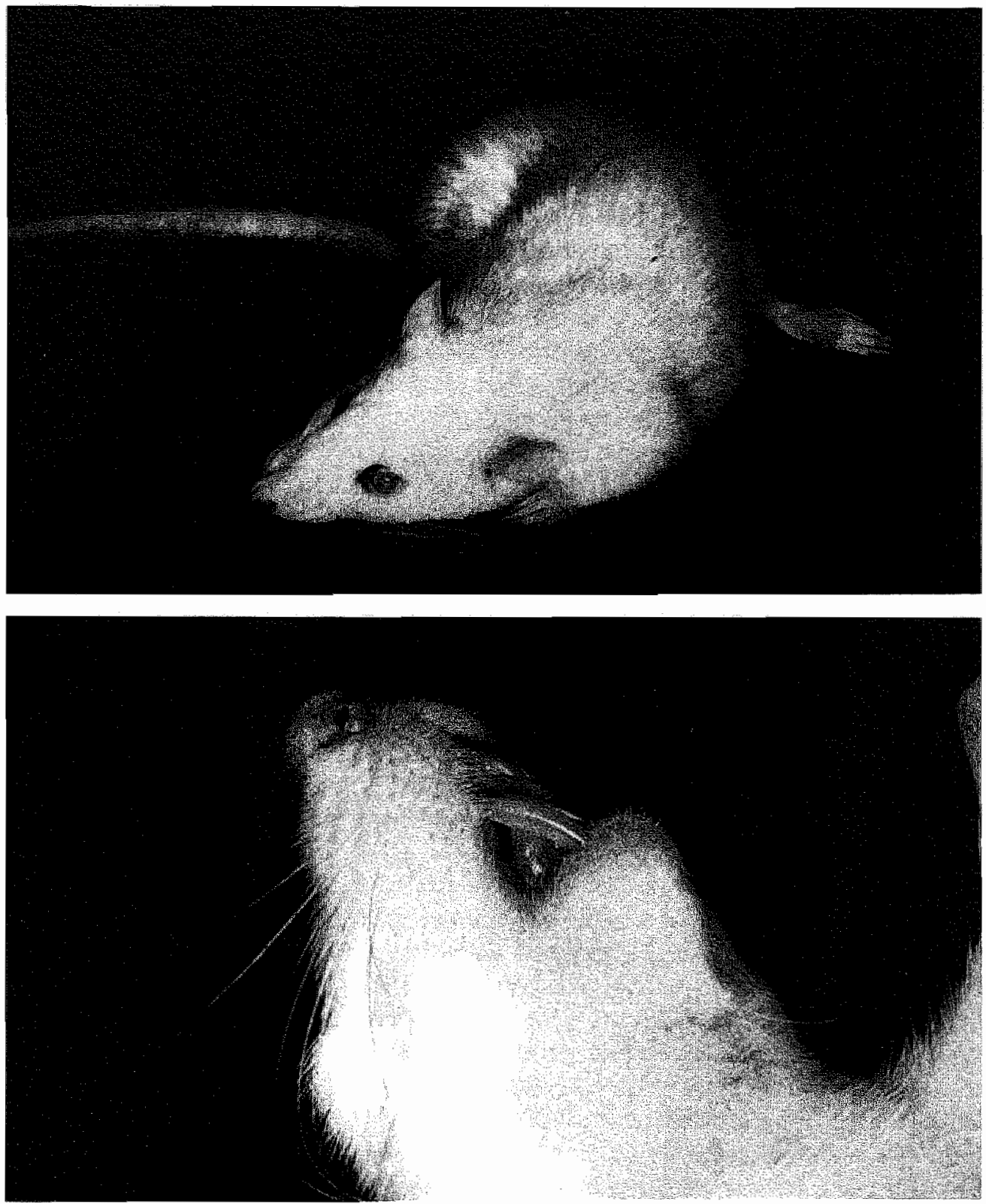

Fig. 1A: Posture of myasthenic rat. The animal lays his head and chest on the floor, the back is exaggeratedly humped with the thighs partially abducted.

Fig. 1B: Close-up of the head of a myasthenic rat. Note the excessive growth of the teeth due to impairment of the masticatory muscles. 
susceptibility can be explained in two ways. Strain dependent differences at the neuromuscular junction might render the highly susceptible strain more sensitive to the neuromuscular blockade. However, no significant difference in sensitivity to dtubocurarine, a competetive antagonist of acetylcholine, between high and low response strains was demonstrable. It is therefore more likely that the degree of the immune response to $A C h \mathbb{R}$ determines the susceptibility to the disease (41).

\subsection{HUMORAL IMMUNE RESPONSE TO ACETYLCHOLINE RECEPTORS}

Immunization of animals with Torpedo AChR results in an antibody response against the immunogen. These antibodies can be measured by means of a double antibody immunoprecipitation assay using ${ }^{125}[-\alpha B T$-labeled Torpedo AChR (46). Antibody titers are expressed as moles $\alpha$-BGT-binding sites precipitated per liter of serum (see material and methods section). The presence of $\alpha$-BGT bound to AChR does not markedly interfere with the precipitation of $\mathrm{AChR}$, since antibodies that are directed against the ligand-binding site are only a small portion of the total (37). However, when unlabelled AChR is preincubated with an excess of antibody, the subsequent binding of $\alpha$-BGT or acetylcholine is inhibited by $50 \%$ or more (47). Since this blockade occurs only at bigh antibody concentration this means that only a small portion of the total antiAChR antibodies are directed against the ligand binding site or very close to that site (47). Another possibility is that anti-AChR antibodies change the conformation of AChR so that it can no longer bind the ligand (44).

\subsubsection{Specificity of the antibodies}

The humoral immune reaction against $\mathrm{AChR}$ from electric organs is quite species specific. A small fraction (1-5\%) of these anti-Torpedo antibodies cross-react with AChRs in the rat's own muscles (46). Most of these cross-reactive antibodies are directed to the main immunogenic region (29). This population of autoantibodies is thought to be responsible for the disease. The time course of the two populations of antibodies and their interrelationship will be discussed in chapters IV and V. These antibodies cross-reacting with muscle AChR can be extracted from muscles of rats with chronic EAMG (43). Autoantibodies against muscle AChR occupy 10-90\% of AChR at the neuromuscular endplate depending upon the severity of disease (see Chapter IV). When rats are immunized with syngeneic $\mathrm{AChR}$, anti-AChR antibodies show extensive cross-reaction (5-80\%) with AChR from both muscle (even human $\mathrm{AChR}$ ) and electric organs $(43,48)$. In contrast sera from $M G$ patients do not show a high percentage of cross-reaction with rat or electric organ AChR. It may be that some of the determinants shared by human $\mathrm{AChR}$ and rat $\mathrm{AChR}$, like those shared with eel or Torpedo $\mathrm{AChR}$, do not provoke a strong humoral response in humans (48). It is still controversial if the rats' own AChR contribute to the autoimmune response in EAMG. This question will be addressed in Chapter $\mathrm{V}$. 


\subsubsection{Mechanisms of humoral immune attack}

Electrophysiological studies in rats with chronic EAMG revealed that the amplitude of the first evoked compound muscle action potential is normal. In rats with signs of clinical weakness, a decremental electromyographic response is seen at low frequencies of stimulation. There is a posttetanic facilitation followed by exhaustion. The amplitude of the mini-endplate potential, produced by the spontaneous release of single quanta of acetylcholine at the rate of about 1 per second, is decreased (49). These electrophysiological abnormalities are provoked by several immunopathological mechanisms: complement mediated focal lysis, an increased turnover of AChR molecules and by immunopharmacological blockade of the acetylcholine binding sites.

\section{a) Complement mediated lysis of the muscular cell membrane.}

Immunoglobulin $\mathrm{G}$ and complement ( $\mathrm{C} 3$ and $\mathrm{C} 9$ ) have been demonstrated by immunoelectron microscopy to be present on the terminal expansions of the junctional folds of the postsynaptic membrane in rats with chronic EAMG (50-53). The distribution of $\mathrm{IgG}$ and complement is similar to that of acetylcholine receptors localized by peroxidase labeled $\alpha$-BGT. These findings and especially the demonstration of the final lytic component $\mathrm{C} 9$ on the postsynaptic folds of myasthenic muscle strongly supports an immune mediated destruction of the muscular membrane (53).

Complement can induce membrane destruction and cell death through the formation of the lytic membrane attack complex, a polymer of $\mathrm{C} 9$ molecules which spans the cell membrane and induces leaks through its central channel (54). The demonstration of $\mathrm{C} 9$ at the neuromuscular endplate is concordant with this mechanism of complement mediated membrane lysis. The activation of the complement cascade also generates anaphylatoxins ( $\mathrm{C} 3 \mathrm{a}$ and $\mathrm{C} 5 \mathrm{a}$ ) which attract polymorphonuclear leucocytes and macrophages which have receptors for those substances (55). These cells are not present in chronic EAMG (27)and MG, but are readily demonstrable in EAMG induced by passive transfer of anti-AChR from EAMG animals. Depletion of $\mathrm{C} 3$ with cobra venom factor prevents the clinical signs, the $A C h R$ defiency and the infiltration with inflammatory cells after passive transfer of anti-AChR antibody (56) . C4 deficient guinea pigs are also resistant to EAMG induced by passive transfer of monoclonal antibody (56). The failure to induce acute EAMG by passive transfer of anti-AChR in complement depleted rats or $\mathrm{C} 4$ deficient guinea pigs proves that complement plays a central role in vivo. As to the role of complement in chronic EAMG, it would be interesting to try to induce chronic EAMG by injection of AChR in CFA into C4 deficient guinea pigs, since prolonged depletion of complement by Cobra venom factor is not possible. This experiment would also clarify the role of complement in conjunction with a second immunopathological mechanism, antigenic modulation of AChR.

\section{b) Antigenic modulation of $A C h R$}

Anti-AChR antibody increases the degradation of $A C h R$ on cultured muscle cells in 
vitro $(57,58)$. This phenomenon, called antigenic modulation, results in a decrease in the number of AChRs on the muscle cell membrane and a decreased effect of available AChR to acetylcholine. Antigenic modulation can be measured in vitro using ${ }^{225}$ I$\alpha$-BGT labeled cultured muscle cells. Addition of anti-AChR antibodies to the tissue culture induces a release of ${ }^{125}$ I-tyrosine in the medium. Since ${ }^{125}$ I- $\alpha$-BGT irreversibly binds to AChRs, the release of ${ }^{125}$ I-tyrosine from degraded $\alpha$-BGT parallels AChR destruction by lysosomal enzymes. This energy dependent process is inhibited by low temperature, DNP, NaF and by inhibitors of cytoskeleton function (58). The effect of anti-AChR antisera does not require complement but depends on the divalent structure of immunoglobulin G. Univalent Fab anti-AChR fragments are ineffective, but crosslinking of AChRs on muscle cells by intact anti-AChR antibodies or Fab fragments and anti $\mathrm{IgG}$ induces a twofold degradation of $\mathrm{AChR}$ (57). Muscle cells in tissue culture display no compensatory increase of $A C h R$ synthesis, since $A C h \mathbb{R}$ synthesis is probably already maximal. In muscle from rats with EAMG degradation of $\mathrm{AChR}$ occurs at approximately the same rate as when diafragms are exposed to anti-AChR antibodies in vitro. It is not known whether in animals with EAMG there is a compensatory increase of AChR synthesis. It also is not known if groups of muscle fibers with increased AChR synthesis are less susceptible to the modulating effect in vivo.

\section{c) Direct block of AChR function by antibody:}

Conceptually, antibodies to the acetylcholine binding site should be very strong inhibitors of AChR function. Antibodies against AChR of animals with EAMG directly affect AChR function when applied to electric organ cells or muscle (59-63). Agonist indluced depolarisation of eel electric organ cells is blocked by preincubation with an excess of anti-AChR antibody. Although all AChRs are bound with antibodies the acetylcholine binding site can still be labelled with ${ }^{125} \mathrm{I}-\alpha$-BGT and no decrease in AChR numbers can be found (64). This suggests that antibodies bound have an allosteric effect on $\mathrm{AChR}$ function.

The analysis of immunopharmacological blockade of AChR can best be studied by means of monoclonal antibodies which by virtue of their restricted specificity bind only to one antigenic determinant on AChR. An antigenic determinant consists of 4-6 amino-acids in a linear sequence or in three dimensional configuration. The acetylcholine binding site is, in view of the small molecular weight of acetylcholline a minute phylogenetically conserved site, probably not larger than the size of one antigenic determinant. It is therefore not surprising that most polyclonal and monoclonal antibodies bind to AChR outside this small acetylcholine binding site; antibodies that bind outside the ligand binding site can however influence $A C h R$ function as measured by altered ion channel opening time and conductance (33). The dissection of the immune response of antibodies against $\mathrm{AChR}$ was performed by means of monoclonal antibodies. Twenty five MABs were tested for their ability to block agonist induced ${ }^{22} \mathrm{Na}^{+}$influx into unilamellar liposomes containing reconstituted AChR. Only two monoclonal antibodies blocked $A C h R$ function without interfering with the ligand bin- 
ding site. These $2 \mathrm{MABs}$ could act by interfering with the propagation of the ligand signal to the ion channel or by directly blocking the function of the ion channel. Very few monoclonal antibodies directed against the acetylcholine binding site have been isolated. These MABs compete with agonists (e.g. carbamylcholine and acetylcholine) or antagonists ( $\alpha$-bungarotoxin, d-tubocuranine, decamethonium) (36). Passive transfer of such a MAB induces acute EAMG within one hour after injection (34). Despite the clear pathogenicity of antibodies to this ligand-binding site, there is little evidence that they play an important pathological role in MG and EAMG. First, such antibodies are only a minor fraction of the totall, which explains why only few MABs affecting $A C h R$ function have been isolated. A library of monoclonal antibodies may be considered representative for the spectrum of antibodies in polyclonal immune serum. Second, the concentration of anti-site antibodies does not correlate closely with severity of disease (65).

In summary, three mechanisms are responsible for the neuro-muscular dysfunction in EAMG, i.e. complement mediated focal muscular membrane lysis, AChR modulation, and blocking of the ligand binding site. The first mechanism is the most important because in C3 depleted rats no acute disease occurs, although $60 \%$ of the AChRs are occupied by antibody (56). In the absence of the lytic action of complement no increased AChR turnover (i.e. antigenic modulation) occurs. Thus, the intact postsynaptic membrane is not susceptible to antibody induced AChR turnover. In contrast, AChRs on cultured muscle cells are susceptible to antibody induced antigenic modulation in the absence of complement. It is Jikely therefore that the lytic cascade of complement factors is necessary to remove the cytoskeletal restraints of the postsynaptic membrane (56).

\subsection{THE CELLULAR IMMUNE RESPONSE TO ACETYLCHOLINE RECEPTORS}

T lymphocytes can be categorized into regulatory cells and effector cells. Regulatory $T$ cells can enhance (helper $T$ cells) or suppress (suppressor $T$ cells) the activity of effector $T$ cells or $B$ cells. The function of effector $T$ cells is either killing target cells (cytotoxic $\mathrm{T}$ lymphocytes) or mediating the delayed type hypersensitivity reaction. To be activated by an antigen, these $T$ lymphocytes must recognize the antigen together with its own histocompatibility antigen.

From the preceding section one might conclude prematurely that EAMG is an antibody mediated disease. However, several $\mathrm{T}$ cell mediated immune reactions can be observed. Positive skin test, typical of a delayed type hypersensitivity (DTH) reaction to AChR were present in rats 3 days after immunization with eel AChR in CFA and Bordetella pertussis. This DTH reaction subsides before the animals develop chronic EAMG, suggesting that cells mediating DTH are not necessarily important effector cells in this model (66). In search for cytoxic T cells, S. Fuchs and her colleagues found that macrophages armed with anti-AChR antibodies were cytotoxic for cultured myocytes. 
The lymphocytes isolated from animals with EAMG were not cytotoxic for muscle cells (67). These findings agree with the presence of macrophages at the neuromuscular endplate of rats with acute EAMG. However, endplates of animals with chronic EAMG show no cellular infiltrate $(50,66)$. The detection of cytotoxic $T$ effector cells will be difficult since muscle cells are very difficult to lyse, on account of a strong cytoskeleton. In view of this property of muscle cells it will be difficult to design assay systems for cytotoxic T lymphocytes in EAMG.

Since EAMG can be transferred by antibody alone, more attention was given to the role of regulatory $T$ cells in EAMG. The contribution of defined lymphocyte populations to the pathogenesis of EAMG has been tested by passive transfer experiments. Transfer of EAMG to normal rats by immune lymph node cells was possible, although a very high number of cells $\left(6 \times 10^{8}\right)$ was required no antibody to rat muscle receptor was detectable (66). It was not possible to induce EAMG in adult rats which were depleted of $\mathrm{T}$ cells by thymectomy and $\mathrm{X}$-irradiation and reconstituted with purified $B$ cells. This suggests that $T$ cells are involved in EAMG as helpers for the B cells in their production of antibody to AChR (66).

A new field opened upon the advent of in vitro techniques for the assessment of the relative contribution of $T$ cells and their subsets and $B$ cells in the pathogenesis of EAMG. Most of these initial studies were performed in mice which were genetically well characterized, but are relatively resistant to the induction of EAMG. In a first attempt to determine the genetic control of EAMG, Christadoss et al. tested the proliferative response by lymph node cells to Torpedo AChR. Studies with congenic and recombinant inbred strains of mice revealed that $T$ cell responses during the induction phase of EAMG (day 7) to Torpedo AChR are controlled by an immune response gene, localised in the IA subregion of the major histocompatibility complex (69). These lymphocyte proilferative responses to AChR are dependent on cells expressing the $T$ helper cell phenotype $\left(1 y t 1^{+2,3^{-}}\right)(70)$. Lymphocyte responses were eliminated by blocking Ia antigens on lymphocyte cell surface with anti-I-A antisera and by removal of adherent (antigen presenting) cells. A spontaneous mutation at the IA subregion $\left(A_{B}\right.$ chain) converted high responsiveness to $\mathrm{AChR}$ to a state of low responsiveness (71). These data imply the antigen presenting cell associated Ia molecule in induction of EAMG, probably in the presentation of $A C h R$ together with la antigen to helper $T$ lymphocytes. These helper $T$ lymphocytes help B lymphocytes to differentiate into antiAChR antibody-forming cells (72). These in vitro results have also been tested in vivo. Indeed in vivo therapy with monoclonal anti-la antibody suppresses immune responses to acetylcholine receptor (73). The in vivo autoantibody responses to mouse muscle $\mathrm{AChR}$ were also roughly under immune response gene control. This $\mathrm{H}-2$ control was not complete since in certain strains of mice (AKR/J, H-2k) genes outside the $\mathbf{H}-2$ complex were found to influence autoantibody responses to $\mathrm{AChR}$ (41).

As mentioned earlier if one wants to relate in vitro cellular responses to AchR to in vivo phenomena and severity of disease, the rat is a far better experimental animal. Work from Noguchi et al. indicated that lymphocytes from rats with chronic EAMG 
proliferate in vitro when $A C h R$ was added to the culture (74). Hohlfeld et al. isolated AChR reactive lymphocytes from rats with chronic EAMG (75). Further culture with self-AChR resulted in the selection of autoreactive $T$ cell clones. In these studies no attempt was made to relate these in vitro proliferation assays to in vivo phenomena. However, transfer of isolated anti-AChR specific $T$ cells into unprimed rats did not induce EAMG unless AChR incorporated in CFA was injected along with AChR primed $B$ cells (76). In summary, it is clear that $T$ cells play an important role in EAMG most likely as $T$ helper cells that cooperate in the antibody response to $\mathrm{AChR}$.

\subsection{PATHOLOGY OF THE NEUROMUSCULAR ENDPLATE IN EXPERIMENTAL AUTOIMMUNE MYASTHENIA GRAVIS}

When the EAMG model was first developped by Patrick and Lindstrom several pathologists in the San Diego area analyzed the muscles of rabbits that died from EAMG, but they could not find clear cut lesions with the light microscope. Not until the rat EAMG model was developed by Lindstrom, Engel, an expert in neuropathology described in detail the ultrastrucutral lesions of the neuromuscular endplate in acute and chronic EAMG.

In acute EAMG induced by injection of AChR in CFA along with Bordetella pertussis or induced by passive transfer of antibodies against $A C h R$ a phase of acute weakness occurs. Light microscopy showes an inflammatory exudate composed predominantly of mononuclear cells with a lesser admixture of neutrophils and rare eosinophils. The inflammatory reaction is confined to the endplates as visualized by the cholinesterase enzymehistochemical reaction. The postsynaptic regions split away from the underlying muscle fibers and the junctional folds are destroyed by macrophages. Some muscle fibers undergo segmental necrosis and invasion by macrophages (50).

Electron microscopic examination shows degenerating postsynaptic folds that are splitting away from the underlying muscle fiber region. These folds are being degraded by macrophages. The nerve terminals remain intact but are separated from the muscle fibers by macrophages $(50,77)$. These lesions are typical for acute phase EAMG but are not observed in muscles from patients with MG.

The chronic phase of EAMG in the rat begins about one month after immunization with AChR in CFA. Light microscopic studies shows no abnormalities (50). Electron microscopic studies shows intense degeneration of the junctional folds $(50,77)$. This results in a widened primary synaptic cleft and a simplified postsynaptic region. Splitting of the synaptic folds from the muscle fibers and phagocytosis of the degenerating folds by macrophages are not seen. The nerve terminals, howewer, remain intact. Morphometric analysis of the postsynaptic regions reveals a $50-60 \%$ decrease in length of the postsynaptic membrane $(50,77)$. Since the AChR sites are located on tips of the synaptic folds this decrease in length implies a proportional greater decrease in the number of acetylcholine receptor sites. 


\subsection{RELEVANCE OF THE EAMG-MODEL FOR MYASTHENIA GRAVIS}

Although Simpson's idea that myasthenia gravis was caused by autoantibodies to the acetylcholine receptor was innovating, his hypothesis was not really believed by other neurologists until $J$. Patrick and $J$. Lindstrom were able to induce anti-AChR antibodies and a myasthenic syndrome in rabbits. Experimental autoimmune myasthenia gravis was also induced in several other species, but most of the studies have been done in rats and mice. The most important clinical features of EAMG and MG is muscular weakness which increases after repeated use of certain muscle groups. Only monkeys develop signs comparable to those of human disease (40). In all animal species with EAMG, like for $M G$, a clear temporary improvement occurs after administration of anti-cholinesterase drugs. This treatment improves the neuromuscular blockade assessed by electromyography with repetitive stimulation. Neostigmine treatment increases the miniature endplate potential in both EAMG and MG.

Besides the electrophysiological similarities between EAMG and MG this experimental model is very useful to analyse the immunological mechanisms operational in MG. First of all, the technology developed during the isolation of Torpedo AChRs made it possible to assay antibodies against AChRs in MG (77). AChRs present in a crude extract of human muscle specifically labeled with ${ }^{125} \mathbb{I}-\alpha$-BGT are used as antigen. This assay has a very high sensitivity and is highly specific for MG. Using this assay Lindstrom et al. and several other investigators showed that most MG patients have antibodies whereas patients with other neurological diseases lack anti-AChR antibodies (79-22). The only exceptions are some thymoma patients, 3\% of RA patients treated with d-penicillamine without MG and some asymptomatic relatives of MG patients (reviewed in ref. 83). Passive transfer of such antibodies from MG patients to mice induces acute EAMG (84). Neonatal MG, the passive transfer experiment of nature, occurs in some babies born from myasthenic mothers (85). EAMG occurs also in neonatal rats born of and nursed by EAMG mothers (86). In the sera of myasthenic pups anti$A C h R$ antibodies can be demonstrated. In the rat most perinatal immunity is conferred via IgG passage to newborns by means of milk from the mother. Therefore neonatal EAMG occurs only in rats nursed by EAMG rats (86). In patients with MG who gave birth to a baby showing neonatal myasthenia, anti-AChR antibodies have been demonstrated in the sera from the infants but not in the mother's mill. Thus although the neonatal form of EAMG in rats appears to be similar to its human counterpart the pathogenesis differs.

The mechanisms by which anti-AChR antibodies induced myasthenia in MG and EAMG are similar. In both chronic EAMG and MG, $\mathrm{C} 3$ is bound to the postsynaptic membrane. The presence of the lytic component $\left(\mathrm{C}_{9}\right)$ of complement at the neuromuscular endplate provides evidence for antibody mediated, complementmediated injury of the postsynaptic region in MG (53).

Antigenic modulation of AChR is a second mechanism by which anti- AChR antibodies cause a neuromuscular blockade in MG and EAMG. Addition of anti-AChR 
antibodies to rat or human cells in culture increases the rate of $A C h R$ destruction. Cross-linking of $A C h R s$ by anti-AChR antibodies is a necessary requirement $(87,89)$. A third mechanism of anti-AChR induced $A C h R$ dysfunction is a direct block of AChR function by antibodies directed at the acetylcholine binding site on a closely adjacent site. The cholinergic binding site may be a major antigenic determinant in a few patients $(90,91)$ but in many sera the anti- $\alpha$-BGT binding site antibody is only a small portion of the total anti-AChR antibody (92). Most of the antibodies in MG sera are directed at the main immunogenic region (MIR). These determinants are oriented in such a way that an antibody bound to one $\alpha$-subunit cannot bind to another $\alpha$-subunit on the same receptor. Antibodies to the MIR are probably very efficient in antigenic modulation and thus increase AChR degradation (32).

These mechanisms are probably responsible for the morphological and functional changes found in MG. The immunopathological lesions are similar as those in chronic EAMG and include mostly postsynaptic changes (51).

Beside humoral, cellular immunity against AChRs is present in MG and EAMG. Peripheral blood lymphocytes (PBL) of MG patients or lymph node cells of animals with EAMG proliferate in the presence of AChRs in vitro (93-97). These proliferating

Table I: Comparison between chronic EAMG and $\mathrm{MG}^{\mathrm{a}}$

EAMG MG

A. Clinical
1) weakness
2) fatigability
3) eye lid ptosis

$\begin{array}{ll}+ & + \\ + & + \\ +1- & +\end{array}$

B. Electrophysiological
1) decremental electromyogram
2) effect of acetylcholinesterase inhibitors
3) reduced mepp amplitude
4) increased curare sensitivity
5) decreased acetylcholine sensitivity

C. Immunological

1) anti-AChR antibodies in serum

2) anti-AChR antibodies at the endplate

3) complement components at the postsynaptic membrane

4) antigenic modulation by antibody

5) antibodies directed to $\mathrm{ACh}$ binding site

6) anti-MIR antibodies

7) neonatal transfer of disease

8) cellular immunity to $\mathrm{AChR}$

9) thymic abnormalities

$\begin{array}{ll}+ & + \\ + & + \\ + & + \\ + & + \\ + & +\end{array}$

a) adapted from Lindstrom et al. (45) 
lymphocytes probably act as $T$ helper cells in order to cooperate with sensitized $B$ cells to produce anti-AChR antibodies (97). This brings us to the role of the thymus in myasthenia gravis. The thymus plays a central role in the maturation process of $T$ lymphocytes. It has been well established that thymectomy induces a remission in about $25 \%$ of MG patients (99). The thymus contains the antigen on "myoid cells" and epithelial cells. More experiments have to be done to analyze the role of the thymus in MG. Unfortunately, rats with EAMG do not develop thymic follicular hyperplasia. Here our faithful companion, the EAMG model, does not bear on the human pathology leaving unsolved questions about the aetiology of myasthenia gravis.

References

1. Simpson JA. Myasthenia gravis: a new hypothesis. Scott.Med. J. 5:419-436, 1960.

2. Lindstrom J. Experimental autoimmune myasthenia gravis. J. Neurol. Neurosurg.Psych. 43: 568-576, 1980.

3. Nachmanson D. Chemical and molecular basis of nerve activity. New York, Academic Press, 1959.

4. Lee CY. Chemistry and pharmacology of polypeptide toxins in snake venoms. Annu. Rev. Pharmacol. 12: $265-286,1972$.

5. Pontes de Carvalho $\mathrm{L}$, Templeman J, Wick $\mathrm{G}$ and Roitt IM. The role of self-antigen in the dewelop. ment of autoimmunity in obsese strain chickens with spontaneous autoallergic thyroiditis. J. Exp. Med. $155: 1255-1266,1982$

6. Raftery MA, Hunkapiller MW, Strader $C D$ and Hood LE. Acetylcholine receptor: complex of homologous subunits. Science 208: 1454-1456, 1980.

7. Lindstrom J, Merlie J and Yogeeswaran G. Biochemical properties of acetylcholine receptor subunits from Torpedo Californica. Biochemsitry 18: 4465-4470, 1979.

8. Conti-Tronconi BM, Raftery MA. The nicotinic cholinergic receptor: correlation of molecular structure with functional properties. Annu Rev. Biochem. 51: 491-530, 1982.

9. Lindstrom $J$, Lennon $V$, Seybold $M$ and Whittingham $S$. Experimental autoimmune myasthenia gravis and myasthenia gravis: biochemical and immunochemical aspects. Ann. NY Acad.Sci. 274: 254-274, 1976.

10. Patrick J, Lindstrom J, Culp B and McMillan J. Studies on purified eel acetylcholine receptor and antiacetylcholine receptor antibody. proc.natl.acad sci.usa 70: 3334-3338, 1973.

11. Noda $M_{n}$ Takahashi $H$, Tanabe $T$, Toyosato $M$, Furutani $Y$, Hirose $T$, Asai M, Inayama $S$, Miyata $T$ and Numa S. Primary structure of $\alpha$-subunit precursor of Torpedo Californica acetylcholine receptor deduced from cDNA sequence. Nature 299: 793-797, 1982.

12. Claudio $T$, Ballivet $M$, Patrick $J$ and Heinemann $S$. Nucleotide and deduced aminoacid sequences of Torpedo Californica aceytlcholine receptor $\alpha$-subunit. Proc.Natl.Acad.Sci. USA 80: 1111-1115,1983. 
13. Noda M, Takahashi $H$, Tanabe $T$, Toyosato M, Kikyotani $S$, Hirose $T$, Asai M, Takashima $H$, Inayama S, Miyata T, Numa S. Primary structures of $\beta$ and $\delta$-subunit precursors of Torpedo californica acetylcholine receptor deduced from cDNA sequences. Nature 301: 251-255, 1983.

14. Lindstrom $J_{n}$ Merlie JP and Yogeeswaran G. Biochemical properties of acetylcholine receptor subunits from Torpedo Californica. Biochemistry 18: 4465-4470, 1979 .

15. Vandlen $R$, Wilson $C$, Eisenach $J$, Raftery $M$. Studies on the composition of purified Torpedo Californica acetylcholine receptor and its subunits. Biochemistry 18: 1845-1854, 1979.

16. Prives $\mathbb{J}$ and Bar-Sagi $\mathrm{D}$. Effect of tunicamycin, an inhibitor of protein glycosylation, on the biological properties of acetylcholine receptor in cultured muscle cells. J. Biol.Chem. 258: 1775-1780, 1983.

17. Einarson $B$, Gullick $W$, Conti-Tronconi $B$, Ellisman $M$, Lindstrom $\mathbb{I}$. Subunil composition of bovine muscle acetylcholine receptor. Biochemistry 21: 5295-5302, 1982.

18. Gotti C, Conti-Tronconi BM, Raftery M. Mammalian muscle acetylcholine receptor purification and characterization. Biochemistry $21: 3148-3154,1982$.

19. Momoi MY, Lennon VA. Purification and biochemical characterization of micotinic acetylcholine receptors of tuman nusele. J. Biol.Chem. 257: 12757-12764, 1982.

20. Karlin A. Molecular properties of nicotinic acetylcholine receptors. In: Poste G, Nicolson $G_{\text {, }}$ Cotman C (Eds.). The cell surface and neuronal function, New York, Elsevier North Holland, Biomedical Press, pp. 19\-260, 1980.

21. Conti-Tronconi BM, Gotti CM, Hunkapiller MW, Raftery M. Mammalian muscle acetylcholine receptor: A supramolecular structure formed by four related proteins. Science 218 : 1227-1229, 1982.

22. Katz $\mathbf{B}$, Miledi $R$. The analysis of endplate noise - a new approach to the study of acetylcholine receptor interaction. In: Motor Intervation of Muscle; Thesleff $S$ (Ed.). London, Academic Press, 1976, pp. $31-50$.

23. Rosenberry T. Acetylcholinesterase: The realtionship of protein structure to cellular localization. In: Martonosi A, Ed. Critical review in membrane transplant, New York, Plenum Press, p. 339-348, 1982.

24. Lambert EH and Elmqvist D. Quantal components of endplate potentials in the myasthenia syndrome. Ann. NY Acad. Sci. 183: 183-199, 1971.

25. Anderson DJ and Blobel $\mathrm{G}$. In witro synthesis, glycosylation and membrane insertion of the four subunits of Torpedo acetylcholine receptor. Proc. Nall. Acad. Sci.USA 78: 5598-5602, 1981.

26. Merlie JP, Sebbane $R$, Tzartos $S_{x}$ Lindstrom J. Inhibition of glycosylation with tunicamycin blocks assentbly of newly synthesized acetylcholine receptor subunits in muscle cells. J. Biol.Chem. 257: 2694-2701, 1982.

27. Pumplin DW, Fambrough DM. Turnover of acetylcholine receptors in skeletal muscle. Ann.Rev. Physiol. 44: 319-335, 1982.

28. Lennon VA, Lindstrom JM and Seybold ME. Experimental autoimmune myasthenia: a model of myasthenia gravis in rats and guinea pigs. J. Exp. Med. $141: 1365-1375,1975$.

29. Lindstron $\mathbb{J}$. Einarson B and Merlie $\mathbb{I}$. Immunization of rats with polypeptide chains from Torpedo acetylcholine receptor causes an autoimmune response to receptors in rats muscle. Proc.Natl.Acad. Sci. USA 75: 769-773, 1978.

30. Tzartos SJ and Lindstrom JM. Monoclonal antibodies used to probe acetylcholine receptor structure: Localization of the main immunogenic region and detection of similarities between subunits. Proc. Natl. Acad.Sci. 77; 755-759, 1980.

31. Tzartos AJ, Seybold ME and Lindstrom JM. Specificities of antibodies to acetylcholine receptors in sera fron myasthenia gravis patients measured by monoclonal antibodies. Proc. Nati.Acad. Sci. 79 : 188-192, 1982.

32. Gullick $\mathrm{W}$, Tzartos $\mathrm{S}$ and Lindstrom $₫$. Monoclonal antibodies as probes of acetylcholine receptor structure. 1 . Peptide mapping. Biochemistry 20: 2173-2181, 1981.

33. Conti-Tronconi BM, Tzartos S and Lindstrom JM. Monoclonal antibodies as probes of acetylcholine receptor structure. II. Binding to native receptor. Biochemistry 20:2181-2199, 1981.

34. Lindstrom JM, Tzartos S and Gullick W. Structure and function of the acetylcholine receptor molecule studied using monoclonal antibodies. Ann. NY Acad.Sci. 377: 1-19, 1981 .

35. Gomez $\mathrm{C}$ and Richman D. Anti-acetylcholine receptor antibodies directed against the $\alpha$-bungarotoxin binding site induce a unique form of experimental myasthenia. PNAS 80: 4089-4093, 1983.

36. Watters $\mathrm{D}$ and Maelicke A. Organization of ligand binding sites at the acetylcholine receptor: a study with monoclonal antibodies. Biochemistry $22: 1811-1.819,1983$. 
37. Lindstrom JM. Autoimmune response to acetylcholine receptors in myasthenia gravis and its animal model. Adv. Immunology 27: 1-50, 1979.

38. Patrick $J$ and Lindstrom JM. Autoimmune response to acetylcholinereceptor. Science 180: 871-872, 1973.

39. Heilbronn E, Mattsson C, Thornell LE, Sjostrom M, Stalberg E, Hilton-Brown $P$ and Elmqvist D. Experimentall myasthenia in rabbits: biochemical, immunological, electrophysiological and morphological aspects. Ann. NY Acad. Sci. 274: 337-353, 1976.

40. Tarrab-Hazdai R, Aharanov A, Silman I, Fuchs $S$ and Abramsky O. Experimental auto-immune myasthenia induced in monkeys by purified acetylcholine receptor. Nature (London) 256: 128 130, 1975.

41. Bermam PW and Patrick J. Experimental myasthenia gravis. A murine system. J. Exp. Med. 151: 204-223, 1980 .

42. Berman PW and Patrick J. Linkage between the frequency of muscular weakness and loci that regulate immune responsiveness in murine experimental myasthenia gravis. J. Exp. Med. 152: 507-520, 1981.

43. Lindstrom JM, Einarson BL, Lennon VA and Seybold ME. Pathological mechanisms in experimental autoimmune myasthenia gravis. I. Immunogenicity of syngeneic muscle acetylcholine receptor and quantitative extraction of receptor and antibody-receptor from muscles of rats with experimental autoimmune myasthenia gravis. J. Exp. med. 144: 726-738, 1976.

44. Vincent A. Immunology of acetylcholine receptors in relation to myasthenia grawis. Phys. Rev, 60: $756-824,1980$.

45. Lindstrom JM, Engel AM, Seybold ME, Lennon VA and Lambert EH. Pathological mechanisms in experimental autoimmune myasthenia gravis. II. Passive transfer of experimental autoimmune myasthenia gravis in rats with anti-acetylcholine receptor antibodies. J. Exp. Med. 144: 739-753, 1976.

46. Lindstrom JM, Lennon VA, Seybold ME, Wittingham S. Experimental autoimmune myasthenia gravis and myasthenia gravis: Biochemical and immunochemical aspects. Ann. NY Acad. Sci. 274: 254-274, 1976.

47. Claudio $T$ and Raftery MA. Inhibition of $\alpha$-bungarotoxin binding to acetylcholine receptors by antisera from animals with experimental autoimmune myasthenia gravis. J. Supramol. Struct. 14: $267-279,1980$.

48. Lindstrom JM, Cambell $M$ and Nave B. Specificities of antibodies to acetylcholine receptors. Muscle Nerve 1: $140-145,1978$.

49. Seybold ME, Lambert EH, Lennon VA and Lindstrom JM. Experimental autoimmune myasthenia: Clinical, neurophysiologic, and pharmacologic aspects. Ann.NY Acad.Sci. 274: 275-282, 1976.

50. Engel $\mathrm{AG}$, Tsujimata $\mathrm{M}$, Lindstrom $\mathrm{JM}$ and Lennon $\mathrm{V}$. The motor endplate in myasthenia gravis and in experimental autoimmune myasthenia gravis. A quantitative ulltrastructural study. Ann. NY Acad. Sci. 274: 60-79, 1976 .

51. Engel AG, Lambert EH and Howard FM. Immune complexes(ligG and C3) at the motor endplate in myasthenia grawis. Ultrastructural and light microscopic localization and electrophysiological correlations. Mayo Clin. proc. 52: 267-280, 1977.

52. Sahashi K, Engel AG, Lindstrom JM, Lambert EH and Lennon VA. Ultrastructural localization of immune complexes ( $\mathrm{GG}$ and $\mathrm{C3}$ ) at the endplate in experimental autoimmune myasthenia gravis. J. Neuropathol.Exp. Neurol. 37: 212-223, 1978.

53. Sahashi K, Engel AG, Lambert $\mathrm{EH}_{n}$ Howard FM Jr. Ultrastructural localization of the terminal and lytic nimth complement component $(\mathrm{C} 9$ ) at the motor endplate in myasthenia gravis. J. Neuropathol.Exp. Neurol. 39: 160-172, 1980.

54. Podack ER and Tschopp J. Polymerization of the ninth component of complement (C9): Formation of poly(C9) with a tubular uitrastructure resembling the membrane attack complex of complement.. Proc. Natl. Acad. Sci. 79: 574-578, 1982.

55. Kunkel SL, Fantone JC and Ward PA. Complement mediated inflammatory reactions. Pathology Annual 11: 127-154, 1971 .

56. Lennon VA, Seybold ME, Lindstrom JM, Cochrane C, Ulevitch $R$. Role of complement in the pathogenesis of experimental autoimmune myasthenia gravis. J. Exp. Med. 147:973-983, 1978.

57. Lennon VA and Lambert EH. Monoclonal antibodies to acetylcholine receptors: Evidence for a dominant idiotype and requirement of complement for pathogenecity. Ann. NY Acad. Sci. 377: 77-95, 1981.

58. Heinemann S, Bevan S, Kullberg R, Lindstrom J, Rice J. Modulation of acetylcholine receptor by antibody against the receptor PNAS USA 74: 3090-3094, 1977. 
59. Penn AS, Chang HW, Lovelace RE, Niemi W and Miranda A. Antibodies to acetylicholine receptors. in rabbits: immunological and electro physiological studies. Ann. NY Acad. Sci. 274: 354-376, 1976.

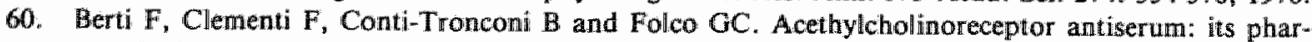
macological properties. Brit. J. Pharmacol. 57: 17-22, 1976.

61. Bevan $S$, Heinemann $S$, Lennon $V A$ and Lindstrom JM. Reduced muscle acetylcholine sensitiwity in rats immunized with acetylcholine receptor. Nature (London) 260: 438-439, 1976.

62. Bevan $\mathrm{S}$, Kullberg $\mathrm{R}$ and Heinemann $\mathrm{S}$. Human myasthenia sera reduce acetylcholine sensitivity of thuman muscle cells in tissue culture. Nature (London) 267: 263-265, 1977.

63. Bevan S, Kullberg RW and Rice J. Acetylcholine-induced conductance fluctuations in cullured human myotubes. Nature (London) 273: 469-471., 1978.

64. Lindstrom J. Immunological studies of acetylcholine receptors. J. Supramol. Struct. 4: 389-403, 1976.

65. Drachman DB, Adams RN, Josifek LF and Self SG. Functional activities of autoantibodies to acetylcholine receptors and the clinical severity of myasthenia gravis. N. Engl.J.Med. 307: 769-775, 1982.

66. Lennon VA, Lindstrom JM and Seybold ME. Experimental autoimmune myasthenia gravis: cellular and humoral immune responses. Ann. NY Acad.Sci. 274: 283-299, 1976.

67. Fuchs S. Immunology of the nicotinic acetylcholine receptor. Curr. Top. Microbiol. Immunol. 85: $1-29,1979$.

68. Green DPL, Miledi R, Perez de la Mora M and Vincent A. Acetylcholine receptors. Phil.Trans. R. Soc. (London) Ser B. 270: 551-559, 1975.

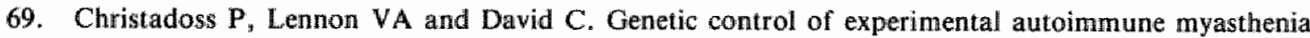
gravis in mice. I. Lymphocyte proliferative response to acetylcholine receptors is under $\mathrm{H}$-2-linked $\mathrm{Ir}$ gene control. J. Immunol. 123: 2540-2543, 1979.

70. Christadoss P, Krco CJ, Lennon VA and David CS. Genetic control of experimental autoimmune myasthenia gravis in mice. II. Lymphocyte poliferative response to acetylcholine receptor is dependent on $\mathrm{Lyt}^{*}{ }^{*} 2,3^{-}$cells. J. Immunol. 126: $1646-1647,1981$.

71. Christadoss P, Lennon VA,Krco CJ and David CS. Genetic control of experimental autoimmune myasthenia gravis in mice. III. Ia molecules mediate cellular immune responsiveness to acetylcholine receptors. J. Immunol. 128: 1141-1144, 1982.

72. Christadoss P, Lennon VA, Krco CJ, Lambert EH and David CS. Genetic control of autoimmunity to acetylcholine receptors: role of Ia molecules. Ann. NY Acad. Sci. 377: 258-277, 1981.

73. Waldor MK, Subramaniam S, McDevitt $H$ and Steinman L. In vivo therapy with monoclonal anti-I-A antibody suppresses immune responses to acetylcholine receptor. Proc. Natl. Acad. Sci.USA 80: 2713-2717, 1983.

74. Noguchi SA, Drachman DB, Adams RN and Hirsch RL. Lymphocyte responsiveness to acetylcholine receptor in rats with experimental autoimmune myasthenia gravis. Ann. Neurol. 8: 32-37, 1980.

75. Hohlfeld R, Kalies I, Heinz F, Kalden JR and Wekerle H. Autoimmune rat T-lymphocytes monospecific for acetylcholine receptors. J. Immunol. 126: 1355-1359, 1981.

76. Wekerle H, Hohlfeld R, Ketelsen VP, Kalden JR and Kalies I. Thymic myogenesis, T-lymphocytes and the pathogenesis of myasthenia gravis. Ann. NY Acad. Sci. 377: 455-476, 1981.

77. Engel AG, Sakakibara H, Sahashi K, Lindstrom JM, Lambert EH and Lennon VA. Passively transferred experimental autoimmune myasthenia gravis. Sequential and quantitative study of the motor endplate fine structure and ultrastructural localization of immune complexes (IgG and C3) and of the acetylcholine receptor. Neurology 29: 179-188, 1979.

78. Lindstrom JM. An assay for antibodies to human acetylcholine receptor in serum from patients with myasthenia gravis. Clin. Immunol. and Immunopathol. 7: 36-43, 1977.

79. Lindstrom $\mathrm{JM}_{n}$ Seybold ME, Lennon VA, Whittingham $S$ and Duane D. Antibody to acetylcholine receptor in myasthenia gravis. Prevalence, clinical correlates and diagnostic value. Neurol, 26: 1054-1059, 1976.

80. Lefvert $A K$, Bergstrom $K$, Matell $G_{1}$ Osterman $P O$ and Pirskanen $R$. Determination of acetylcholine receptor antibody in myasthenia gravis: clinical usefulness and pathogenic implications. J. Neurol. Neurosurg. Psych. 41: 394-403, 1978.

81. Limburg $\mathrm{PC}_{*}$ Humnel $\mathrm{E}_{\mathrm{*}}$ The TH, Oosterhuis HJGH. Anti-acetylcholine receptor antibodies in myasthenia gravis. 1. Their relation to the clinical state and the effect of therapy. J. Neurol.Sci. 58 : $357-370,1983$. 
82. Compston DAS, Vincent A, Newson-Davis J and Batchelor JR. Clinical, pathological, HLA antigen and immunological evidence for disease heterogeneity in myasthenia gravis. Brain 103: $579-601,1980$.

83. Oosterhuis HJGH. Myasthenia Gravis. In: Clinical Neurology and Neurosurgery monographs. Glaser $\mathrm{OiH}$ et al., Eds., vol. 5, Churchill Livingstone, p. 105, 1984.

84. Tayka KV, Drachman DB, Pesironk A and Kao I. Myasthenia gravis: passive transfer from man to mouse. Science 190: 397-399, 1975.

85. Namba T, Brown SB and Frob D. Neonatal myasthenia gravis: report of two cases and review of the literature. Pediatrics 45: 488-504, 1970.

86. Sanders DB, Cobb EE and Winfield $J B$. Neonatal experimental autoimmume myasthenia gravis. Muscle Nerve 1: 146-150, 1979.

87. Kao I and Drachman DB. Myasthenic immunoglobulin accelerates acetylcholine receptor degradation. Science 196: 527-529, 1977.

88. Drachman DB, Angus CW, Adams RN, Michelson JD and Hoffman GJ. Myasthenic antibodies crosslink acetylcholine receptors to accelerate degradation. N. Engl. I. Med. 298: 1116-1122, 1978.

89. Drachman DB, Angus CW, Adams RN and Kao I. Effect of myasthenic patients immunoglobulin on acetylcholine receptor turnover: selectivity of degradation process. Proc. Natl. Acad. Sci. 75: $3422-3426,1978$.

90. Almon R, Andrews $\mathrm{CG}$ and Appel SH. Serum globulin in myasthenia gravis: inhibition of $a-$ bungarotoxin binding to acetylcholine receptors. Science 186: 55-57, 1974.

91. Almon R and Appel SH. Cholinergic sites in skeletal muscle: interaction with concanavalin A. J. Neurochem. 27: 1513-1519, 1976.

92. Vincent A. Immunology of acetylcholine receptors in relation to myasthenia gravis. Phys. Rev, 60: $757-824,1980$.

93. Abramsky O, Aharanov A, Webb C and Fuchs S. Cellular immune response to acetylcholine receptorrich fraction in patients with myasthenia gravis. Clin. Exp. Immunol. 19: 11-16, 1975.

94. Richman D, Patrick I and Arnason B. Cellular immunity in myasthenia gravis: response to purified acerylcholine receptor and autologous thymocytes. N. Engl. J. Med. 294: 694-698, 1976.

95. Conti-Tronconi $\mathrm{BF}$, Dipadova $\mathrm{F}$, Morgutti $\mathrm{M}$, Missiroli A and Frattola L. Stimulation of lymphocytes by cholinergic receptor in myasthenia gravis. J'. Neuropathol. Exp. Neurol. 36: 157-162, 1977.

96. Conti-Tronconi $\mathrm{BM}$, Morgutti $\mathrm{M}$, Albizzati $\mathrm{MG}$ and Clementi $\mathrm{F}$. Lymphocyte stimulation by acetylcholine receptor in polymyositis. J. Neurol. 217: 281 286, 1978.

97. Conti-Tronconi BM, Morgutti $M$, Schirlanzoni $A$ and Clementi $F$. Cellular immune response against acetylcholine receptor in myasthenia gravis: I. Relevance to clinical course and pathogenesis. Neurol. (Minneap) 29: 496-501, 1979.

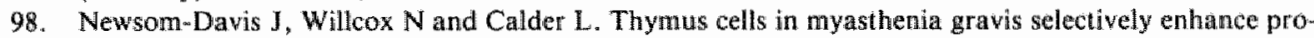
duction of anti-acetylcholine receptor antibody by autologous blood lymphocytes. N. Engl. J. Med. 305: 1313-1318, 1982.

99. Oosterhuis HJGJ. Myasthenia gravis. In: Clinical Neurology and Neurosurgery Monographs ، Glaser GH et al., Eds., vol. 5, Churchill Livingstone, p. 51-76, 1984. 



\section{CHAPTER III:}

\section{Immunogenicity of Acetylcholine receptors: in vitro studies}

\subsection{INTRODUCTION}

The immunogenicity of glycoproteins such as acethylcholine receptors can be tested in vivo and in vitro. In vivo immunogenicity depends on the assay systems, - e.g. specific antibody detection - used and is operationally defined since induction of specific unresponsiveness may give false negative results (1). Consequentiy in vitro assays which measure specific stimulation and proliferation of $\mathrm{T}$ cells and/or antibody production are preferred; these in vitro assays allow in addition to measurements of antibody a precise analysis of antigen presentation, and of the responding $\mathrm{T}$ cell subsets (2). In vitro assays for immunogenicity can be performed using primed or unprimed lymphocytes. The first to develop in vitro "immunization" of unprimed mouse lymphocytes to sheep erythrocytes were Mishell and Dutton using spleen cell suspensions (containing antigen presenting cells, $\mathrm{T}$ lymphocytes and $\mathrm{B}$ lymphocytes) and greatly improved tissue culture conditions (3). Using these culture conditions, however, primary "immunizations" to soluble antigens are difficult to achieve and consequently primed lymphocytes from (immunized animals) are mostly used. The first to describe a lymphocyte proliferation assay using sensitized lymphocytes and soluble antigens was Pearmain (4) using lymphocytes from tuberculine positive individuals and PPD. Corradin (5) scaled the culture system down to microtiter plates in order to analyse the proliferative response of lymph node cells of primed mice to protein antigens. Since this technique is economical and allows the handling of many samples we decided to adapt it in order to study the immunogenicity of AChR receptor, using primed lymphocytes. In order to answer our questions the assay system had to be specific and sensitive and had to allow analysis of responding $T$ cell population and of specificities of the antibodies produced in vitro. The questions asked in terms of $A C h R$ immunogenicity in the secondary immune response in vitro were:

1) whether or not the way in which the receptor was presented to the lymph node cells influenced immunogenicity. This question was asked because in vivo the acetylcholine receptor is inserted into the bilayer of the cell membrane whereas the isolated $A C h R$ is solubilized in detergents which may influence immunogenicity.

2) whether or not antigen presenting cells were required to signal primed $T$ and $B$ cells to respond to AChR. This question was asked in order to differentiate antigen processed $T$ cell mediated $B$ cell responses from direct $B$ cell activation.

3) whether or not the $T$ and $B$ cell responses were directed to the main immunogenic region (MIR) of the AChR since in vivo at any rate the antibody response is mainly directed to the MIR region $(36,37)$. 


\subsection{DESIGN OF THE EXPERIMENTS: The assay system}

We developed an antigen-induced lymphocyte proliferation system with a double readout (6). First we measured the antigen-induced proliferative capacity of primed lymphocytes in vitro, taken from animals with chronic EAMG, by $\left[{ }^{3} \mathrm{H}\right]$-thymidine desoxyribose incorporation. The level of incorporation of this nucleoside is a measure for the rate of DNA synthesis. Secondly, we measured the amount of auto-antibody produced against $A C h R$ in each culture, by means of a sensitive radioimmunoassay using ${ }^{125}$ 1- $\alpha$-BGT-AChR as antigen (see material and methods section, p.155).

The culture conditions for both read-out systems were very similar and therefore always performed in parallel for each experiment.

\subsubsection{Lymphocyte proliferation culture system}

Popliteal, inguinal and paraaortic lymph nodes and spleens were removed under aseptic conditions from Lewis rats with chronic EAMG i.e. 42 days after the primary injection with $15 \mu \mathrm{g} \mathrm{AChR}$ in CFA and 7 days after the booster injection with the same amount of antigen. Single cell suspensions were prepared by forcing the lymph nodes or spleens through a stainless screen ( 60 mesh opening). The cell suspension was subsequently filtered through a Nitex screen (100 mesh opening) followed by three washes in Hanks' balanced salt solution (HBSS). The cells were resuspended at a concentration of $1 \times 10^{6}$ cells $/ \mathrm{ml}$ in RPMI 1640 (Flow laboratories) supplemented with $5 \%$ Lewis rat serum, $100 \mathrm{U}$ penicillin, $100 \mu \mathrm{g}$ streptomycin, and $5 \times 10^{-5} \mathrm{M}$ 2-mercapto-ethanol. Triplicate cultures of $2 \times 10^{5}$ cells $/ 0.1 \mathrm{ml}$ were incubated in flat-bottomed microtiter plates ( 3040 microtest II, Falcon Plastics) for 5 days at $37^{\circ} \mathrm{C}$ in $5 \% \mathrm{CO}_{2}$ in a humidified atmosphere. One hundred microliters of AChR previously dialyzed against $250 \mathrm{~mL}$ PBS and diluted in RPMI 1640 was added to each well at the start of the culture to give a concentration ranging from $0.005 \mu \mathrm{g} /$ culture $\left(2 \times 10^{-10} \mathrm{M}\right)$ to $0.5 \mu \mathrm{g} /$ culture $\left(2 \times 10^{-8}\right.$ M). The cultures were pulsed with $1 \mu \mathrm{Ci}$ tritiated thymidine $\left[{ }^{3} \mathrm{H}\right] \mathrm{TdR}, 5 \mathrm{Ci} / \mathrm{mM}$, Amersham, England), $24 \mathrm{hr}$ before the cells were harvested with an automated cell harvester. The filters (Titertek harvest filters no. 78-105-05) were dried, placed in $3 \mathrm{ml}$ of scintillation fluid (OCS, Amersham, U.K.) and counted in a scintillation counter. The results were expressed as mean counts per minute (cpm) minus background of triplicate cultures \pm standard error. In some instances the background values (although subtracted) are also given.Peripheral blood lymphocytes were purified from heparinized ( $40 \mathrm{IU} / \mathrm{ml}$, preservative free) blood obtained by cardiac puncture. Whole blood was diluted 1:2 with HBSS and lymphocytes were purified on Ficoll-Hypaque (Pharmacia) and a sucrose gradient according to the procedure of Perper et al. (7) (for details see appendix, p.153). These cells were cultured at a density of $1 \times 10^{6}$ cells $/ \mathrm{ml}$ under identical conditions as were used for lymph node and spleen cells. 


\subsubsection{Antibody synthesis in vitro}

Immune lymphocytes $\left(1 \times 10^{6}\right.$ cells/ml) were cultured in triplicate in the presence of increasing amounts Torpedo AChR in $200 \mu \mathrm{I}$ RPMI 1640 (supplemented as described in the proliferation assay) for 5 days in a humidified atmosphere of $5 \% \mathrm{CO}_{2}$. The cells were then centrifuged in microtiter plates at $200 \mathrm{~g}$ at roomtemperature and washed once with $200 \mu \mathrm{l}$ RPMI 1640 to remove AChR that might interfere with the radioimmunoassay. After resuspending the cells in $200 \mu \mathrm{l}$ supplemented medium, the cultures were incubated for an additional 24 hours. Aliquots $(50 \mu \mathrm{l})$ of the tissue culture fluid were assayed for antibody to AChR by radioimmunoassay (see material and methods section p.155).

\subsection{AChR INDUCED LYMPHOCYTE PROLIFERATION}

\subsubsection{The proliferative response of lymphoid cells from various anatomic sites}

Since immunogens may in a dose dependent fashion specifically suppress or elicit immune responses (7) a dose response curve was made; we looked in addition to the anatomic origin i.e. lymph node, spleen and peripheral blood, of the lymphoid cells used, since this may influence the proliferative response observed (5).

\section{Results and comments.}

The addition of $\mathrm{AChR}$ in vitro to $\mathrm{ACh} R$ primed rat lymphocytes induces proliferation. The $\left[{ }^{3} \mathrm{H}\right]$-thymidine incorporation increases linearly with the log of the AChR concentration added in vitro starting at $2,5 \mathrm{ng} / \mathrm{ml}$ to an AChR concentration of $0.25 \mu \mathrm{g} / \mathrm{ml}$ $\left(2 \times 10^{-9} \mathrm{M}\right)$. A plateau is reached at a concentration of $2.5 \mu \mathrm{g} / \mathrm{ml}\left(2 \times 10^{-8} \mathrm{M}\right)$ (fig. 1$)$. A culture period with $A C h R$ of 4 to 5 days is found to be optimal with a sharp decline thereafter (fig. 2). This is not the result of cell death but probably of exhaustion of the media since the viability of the cells after 5 days in culture is still greater than $85 \%$. In view of these findings, the cells were cultured for 5 days throughout the study. Because of the limited amounts of affinity-purified rat muscle AChR available, extended dose or kinetic studies were not carried out. Instead the conditions optimal for Torpedo AChR were used $\left(2,5 \mu \mathrm{g}\right.$ muscle $\mathrm{AChR} / \mathrm{ml}\left(2 \times 10^{-8} \mathrm{M}\right)$ and a culture period of 5 days). Peripheral blood lymphocytes proliferated in the presence of Torpedo AChR, but the extent of this response was only $10 \%$ of that of lymph node cells (fig. 3). Spleen cells cultured under identical conditions did not proliferate significantly.

AChR- induced proliferation is extensive with lymph node cells, minimal with peripheral blood lymphocytes, and absent with spleen cells. Several factors can account for these differences. First, the route of immunization preferentially stimulates the popliteal, inguinal and paraaortic lymph nodes. Because very low concentrations of the immunogen are used, most of the $\mathrm{AChR}$ preparation may be retained by macrophages 


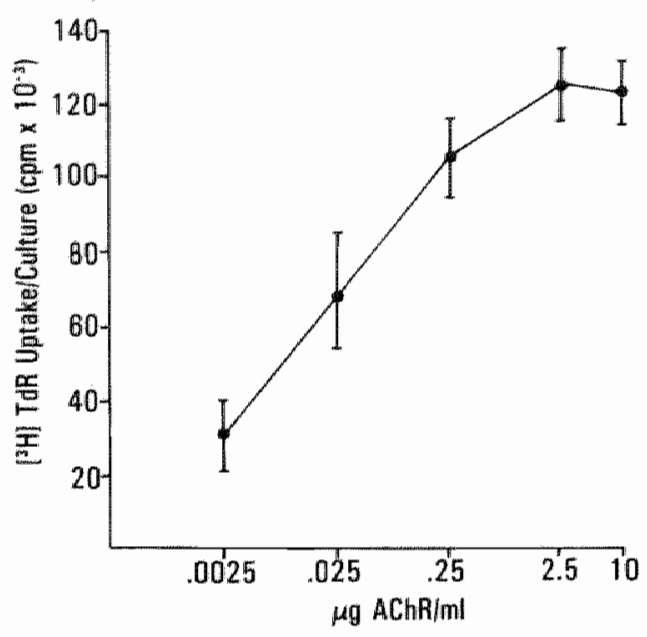

Fig. 1: AChR concentration dependency of the proliferative response in vitro. Forty-two days after immunization with $15 \mu \mathrm{g}$ of Torpedo $\mathrm{AChR}$ lymph node cells were cultured in the presence of the indicated concentrations of Torpedo AChR $\left(0.02-2 \times 10^{-8} \mathrm{M}\right)$ for 5 days.

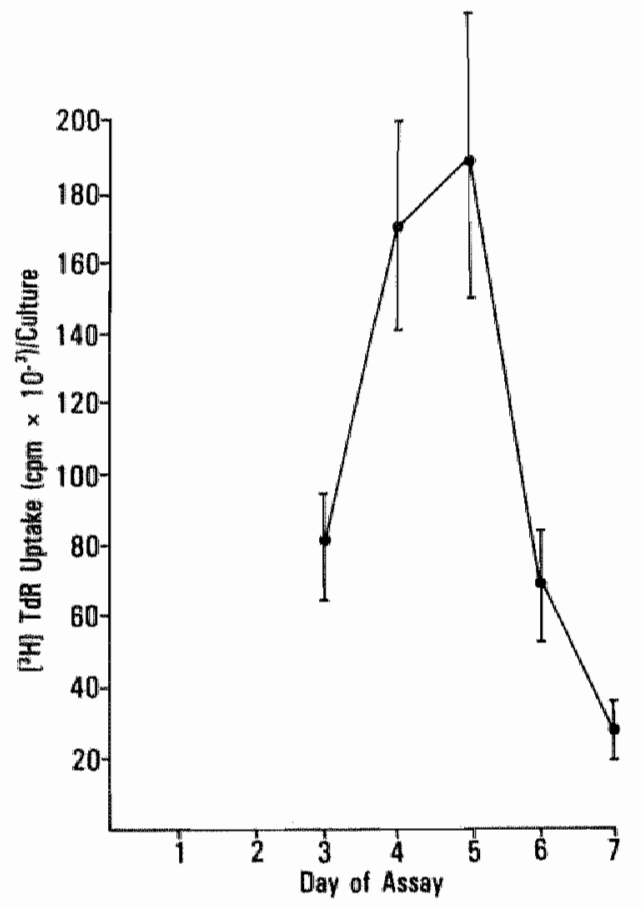

Fig. 2 : Kinetics of the proliferative response to Torpedo AChR. Rats were immunized with 15 $\mu \mathrm{g}$ AChR and sacrified 45 days later. AChR was added to the cultures at a concentration of 2.5 $\mu \mathrm{g} / \mathrm{m} \Perp\left(2 \times 10^{-8} \mathrm{M}\right)$. 


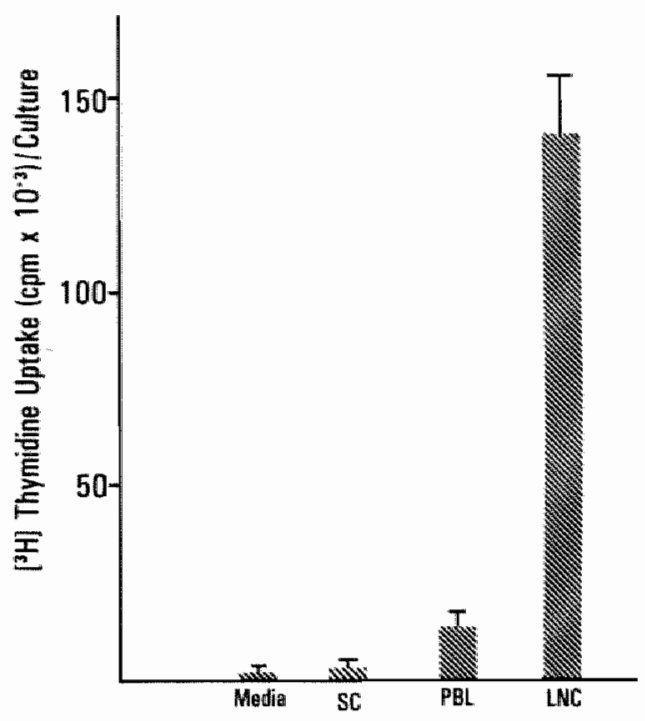

Fig. 3. Comparison of the proliferative response to Torpedo AChR of peripheral blood lymphocytes (PBL), lymph node cells (LNC), and spleen cells (SC) in rats with EAMG. In each case, $2 \times 10^{5}$ cells were used per well.

in lymph nodes. This compartmentalization has also been shown in other systems (5). Secondly, $T$ suppressor cells might be responsible for the inhibition of $\mathrm{T}$ proliferation in spleen cells, in that suppressor cells preferentially home in this organ (8). Rat spleen cells also contain suppressor macrophages. Indeed when these cells are removed by filtration on G-10 Sephadex columns, spleen cells do not suppress the secondary in vitro response to AChR (data not shown). In experimental allergic encephalitis, Richert et al. also found no proliferation, measured by $\left[{ }^{3} \mathrm{H}\right]$-thymidine uptake, after incubation of spleen cells with basic protein. However, antigen-reactive cells were present in the spleens of these animals, shown by the observation that small numbers of cells $(2.5 \mathrm{x}$ $\left.10^{6}\right)$ stimulated in vitro were able to proliferate in vivo after transfer to naive recipients (10). Peripheral blood lymphocytes of rats with EAMG, however, do show proliferation. This population presumably represents circulating lymphocytes that leave the draining sites. Thus, the responsiveness of peripheral blood lymphocytes in EAMG and possible also in MG does not reflect the responsiveness in regional lymphoid tissue.

\subsubsection{The immunogenicity of soluble $A C h R$, native membranes and liposome incorporated AChR}

Since AChRs are in vivo incorporated into the lipid bilayer of the postsynaptic membrane at the neuromuscular junction it is essential - in terms of assessing immunogenicity - to compare solubilized AChR with AChR incorporated into mem- 


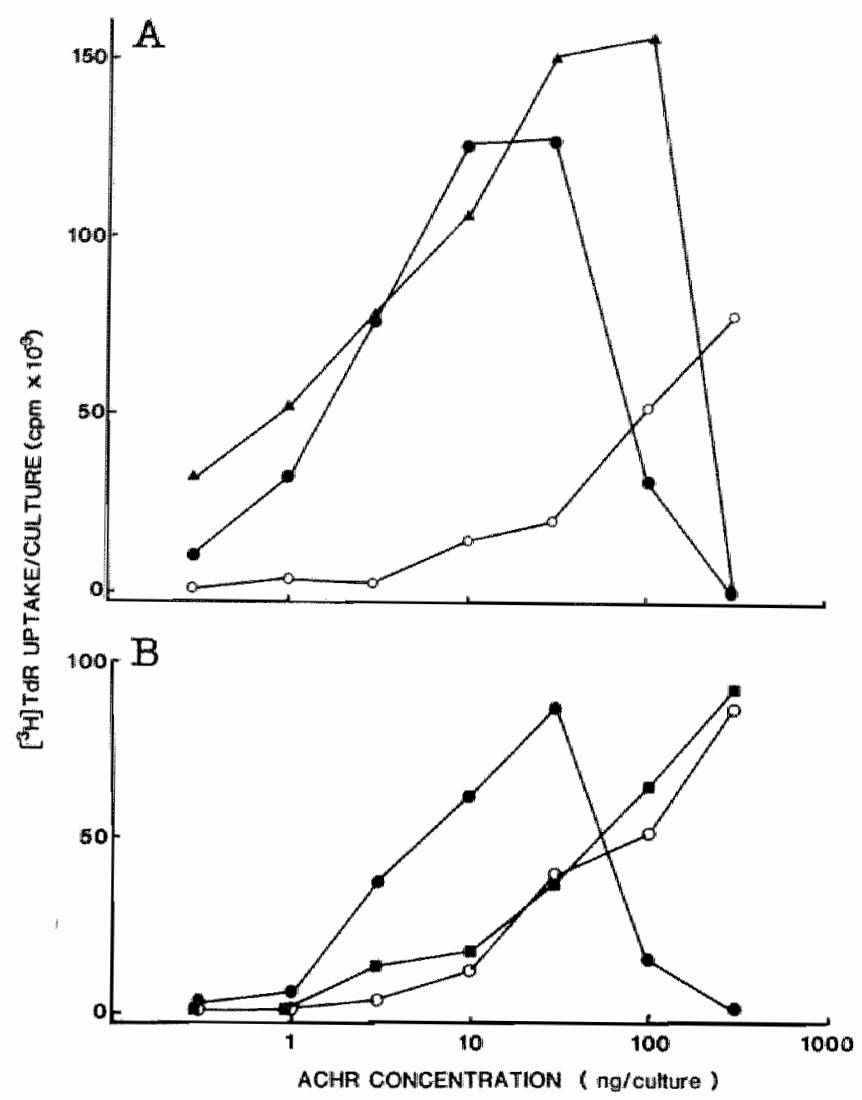

Fig. 4 : Proliferative responses of lymph node cells in vitro after exposure to AChR. Lymph node cells $\left(2 \times 10^{5} \mathrm{cells} /\right.$ well) were cultured for 5 days in the presence of the indicated concentration of soluble $\mathrm{AChR}$, AChR incorporated into regular liposomes, $\mathrm{AChR}$ incorporated into liposomes supplemented with $20 \% \mathrm{w} / \mathrm{w}$ cholesterol, or native electric organ membranes.

branes. Membrane incorporated $\mathrm{AChR}$ was used in two forms: native membranes rich in AChR from the electric organ of Torpedo californica and purified, soluble AChR incorporated into model membranes (liposomes). These membrane incorporated AChRs differ in size and density. AChR rich native membranes $(0,4 \mu(11))$ are four times larger than reconstituted liposomes $(0.06-0.14 \mu(12))$ and AChRs are about 5 fold more densily packed in native membranes compared to liposomes containing AChR $(11,12)$. That these liposomes contain physiologically active $A C h R$ was demonstrated by the finding of agonist induced sodium uptake that can be blocked by neurotoxins, curare and local anaesthetics (13).

Since liposomes can be visualized ultrastructurally we studied in addition to the proliferative $T$ cell response, the ultrastructure of macrophages in order to analyze ultrastructurally if macrophage processing of AChR containing liposomes had occurred and if this could be related to immunogenicity. 
Results and comments.

$\mathrm{AChR}$ incorporated into lipid vesicles (i.e. liposomes) elicit a 25 fold larger response than soluble AChR when added to cultures of immune lymphocytes at concentrations of less than $3 \mathrm{ng} /$ culture (fig. 4). A good proliferative response against soluble AChR is observed at doses between 3-30 ng/cultures. AChRs in liposomes, however, still provide at least a 7 fold enhancement of lymphocyte proliferation in this range of concentrations. When added at concentrations larger than $30 \mathrm{ng} /$ culture (approximately 2-4 $\mu \mathrm{g}$ of lipid /culture is added at this point) these reconstituted vesicles appear toxic to the cells. Presence of cholesterol $(20 \% \mathrm{w} / \mathrm{w})$ in these proteoliposomes appears to shift this toxic effect to higher doses (around $300 \mathrm{ng} /$ culture) (fig. 4A) Native AChR-rich membranes from Torpedo electric organ appear to be no more immunogenically potent than soluble AChR. (fig. 4B). When liposomes prepared in the abscence of AChRs are added to lymphocyte cultures, no proliferative responses above background values can be detected.

After exposure of lymphocyte cultures to AChRs in reconstituted liposomes, macrophages can be observed which have accumulated large quantities of cytoplasmic vacuoles, ranging in size between 1 and $7 \mu$ in diameter (fig. 5). These structures apparently result from phagocytosis of the liposomes and subsequent liposomal fusions with the cytoplasm of the cell. These macrophages are surrounded by numerous lymphocytes with which they appear to interact extensively through cellular processes and pseudopods enfolding the lymphocytes (details of these interactions can be seen in the insets to fig. 5). The lymphocytes themselves appear to be devoid of the cytoplasmic vacuoles observed in the interior of the macrophages. The phagocytosed vacuolar structures occasionally appear to be most prominent near the sites of macrophage lymphocyte interactions. Liposomes devoided of AChRs are also accumulated by macrophages, but these macrophages are not surrounded by lymphocytes.

$\mathrm{ACh}$ reconstituted into vesicles containing soybean lipid plus cholesterol (20\% $\mathrm{w} / \mathrm{w})$ appear to confer to the macrophages a lightrefractive appearance after phagocytosis, allowing their identification by phase contrast microscopy (fig. 6A). The macrophages can then be visualized as single highly refractive cells within large colonies of proliferating lymphocytes. This is not observed when soluble $A C h R$ is presented as antigen to the culture (fig. 6B) or when cholesterol is not present as a component of the AChR containing liposomes (data not shown).

This experiment shows first that in terms of immunogenicity solubilized $A C h R$ is equal to $\mathrm{AChR}$ in plasma membranes of Torpedo californica (= native membranes); thus solubilized AChR was used for further studies (vide infra) on immunogenicity. The experiment shows in addition that $\mathrm{AChR}$ incorporated in liposomes are highly immunogenic and circumstantial morphological evidence suggests that antigen presenting cells (macrophages) are involved in triggering the $T$ cell proliferation in this model. This issue will be analyzed in separate experiments with defined cell populations (see section 3.5). 


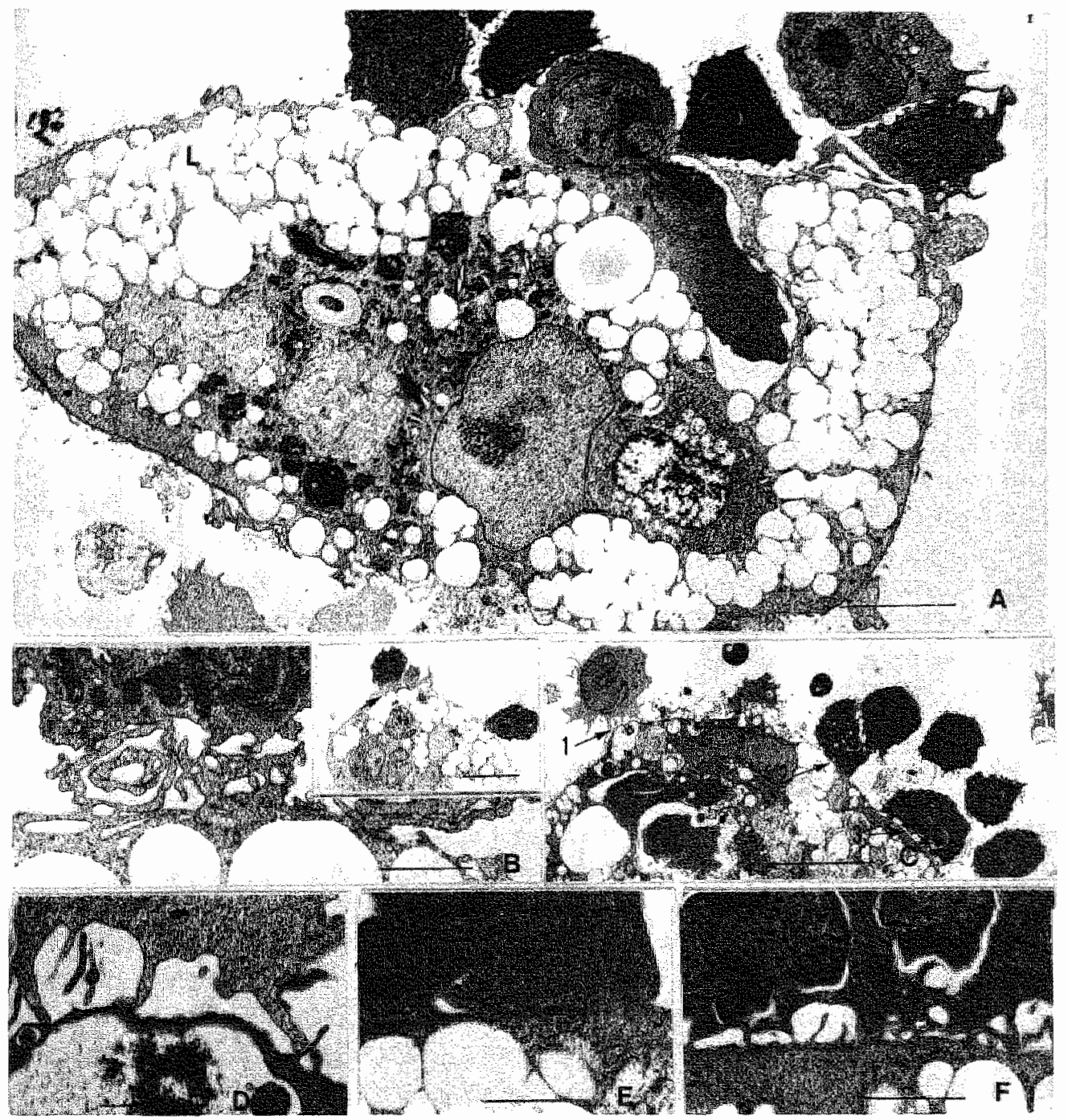

Fig. 5 : Electron microscopic observation of the interaction between macrophages and lymphocytes in cultures exposed to AChR containing liposomes. Lymphocytes $\left(2 \times 10^{5}\right.$ cells $/$ well) were cultured for 5 days in the presence of AChR incorporated in cholesterol $(20 \% \mathrm{w} / \mathrm{w}) \mathrm{sup}$ plemented liposomes.

(A) A macrophage surrounded by several lymphocytes. The cytoplasm of the macrophage is filled with electron translucent lipid droplets (L), many of which appear in the process of fusion. Althoug a phagosomal membrane is not evident in this stage, these vacuoles are likely to represent modified forms of phagocytosed liposomes. $X 2,400$, the bar indicates $8.0 \mu$

(B) Details of the interactions between macrophage and a lymphocyte. The inset displays a low magnification view of the field. The arrow in the inset indicates the interaction site, displayed in the figure. $X 10,800$, the bar indicates $1.5 \mu$ Inset : $X 900$, the bar indicates $10 \mu$ 
(C-F) Details of the interactions between a macrophage and surrouding lymphocytes. Arrows 1 , 2 and 3 in $C$ indicate areas enlarged in $D, \mathbb{E}$ and $F$, respectively. The contacts between the macrophage and the surrouding lymphocytes are made via macrophage philopodia as shown in $B$, both macrophage and lymphocyte philopodia as demonstrated in $D$ and $F$, and through a large area of apposed membrane as shown in $D$.

C: $\times 1,200$, the bar indicates $15.0 \mu$

$\mathrm{D}: \mathrm{x} 1,200$, the bar indicates $1.5 \mu$

E : $\mathrm{x} 1,200$, the bar indicates $1.5 \mu$

$\mathrm{F}: \mathrm{x} 1,200$, the bar indicates $2.0 \mu$

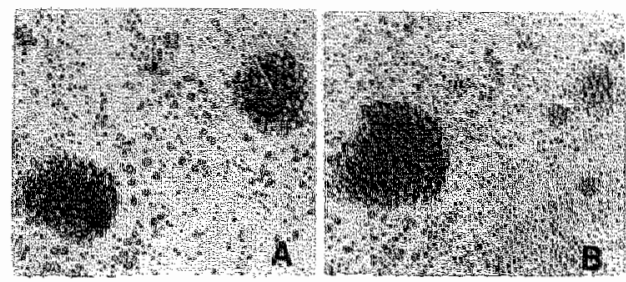

Fig. 6 : Lymphocyte proliferation in cultures exposed to AChR as observed by phase-contrast microscopy. Immune lymph node cells were cultured for 5 days in the presence of AChR incorporated into liposomes supplemented proteoliposomes. X25.

\subsubsection{Effect of the main immunogenic region (MIR), the sites outside the MIR, and the subunits of the Torpedo $\mathbf{A C h R}$ on the in vitro proliferative response}

In this experiment the hypothesis was tested that the main immunogenic region (MIR) of the AChR - to which 50-70\% of the autoantibodies elicited in vivo bind - was most likely responsible for the proliferative responses described in the experiments above. Therefore the main immunogenic region of the $A C h R$ molecule was selectively destroyed by reduction and carboxymethylation ( $\mathrm{RCM}-\mathrm{ACh}$ ) or alternatively the antigenic sites outside the MIR were removed by trypsinisation.

The rationale of this approach is as follows:

Torpedo $\mathrm{AChR}$, a complex pentameric molecule is irreversibly denatured under reducing conditions. Recombinations of the opened disulphide bridges was prevented by iodoacetamide. (for details see material and methods section, p.151). The resulting reduced and carboxymethylated AChR (RCM-AChR) is still assembled as a pentamer when analysed under nondenaturing conditions (see chapter IV). Functionally however $\mathrm{RCM}-\mathrm{AChR}$ is altered in that it does not bind $\alpha$-bungarotoxin or other cholinergic ligands $(14,15)$. Immunologically RCM-AChR is also different from native-AChR (see Chapter IV). Mapping experiments using a panel of monoclonal antibodies revealed that RCM-AChR lacks the main immunogenic determinant (MIR), an immunodominant epitope on native $A C h R$ against which most of the circulating autoantibodies of patients with $\mathrm{MG}$ or animals with EAMG, are directed. It is therefore not surprising that RCM-AChR does not induce EAMG although it is a good immunogen that in- 

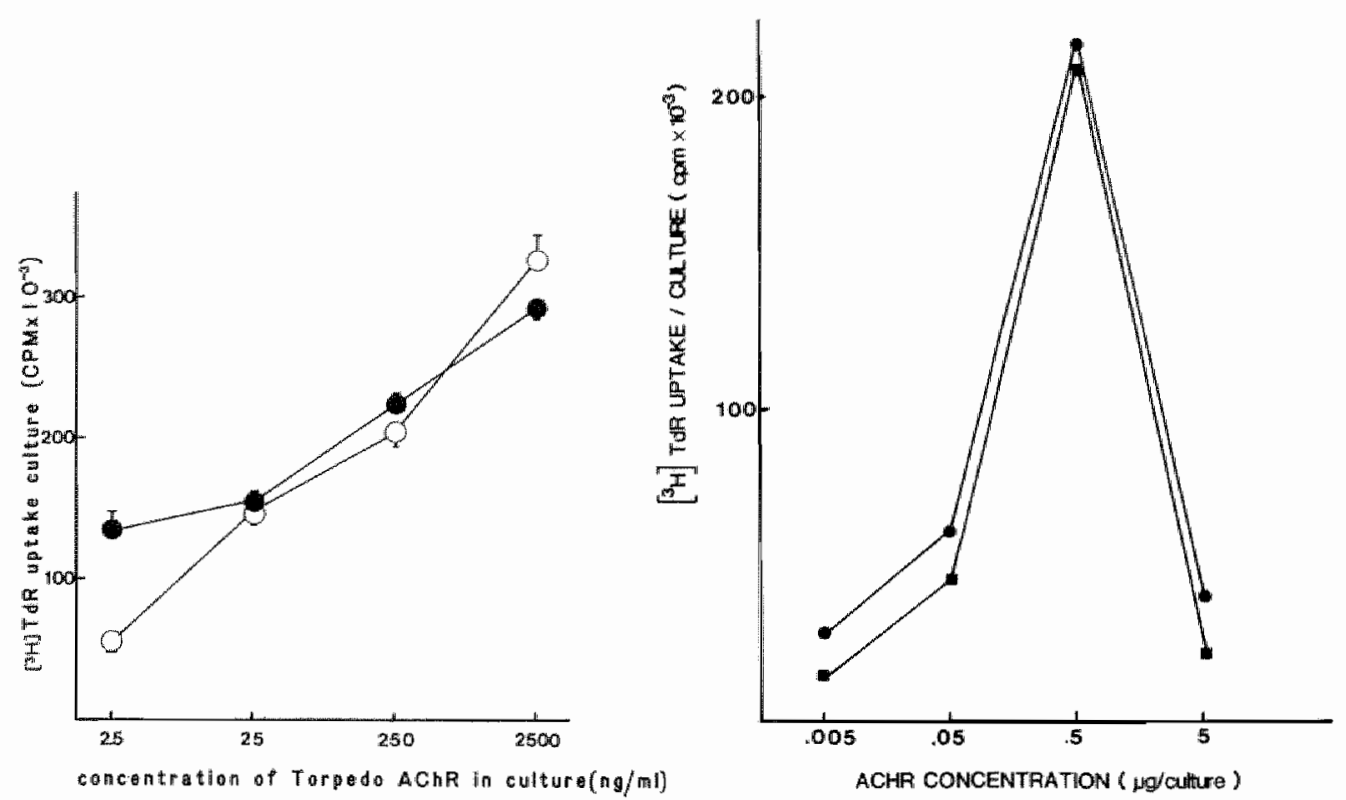

Fig. 7A : Dose response curve of the proliferative response in vitro against RCM-AChR $(0)$ compared to native $\mathrm{AChR}(\bullet)$.

Thirty five days after immunization with $15 \mu \mathrm{g}$ native Torpedo $\mathrm{AChR}$ lymph node cells were cultured in the presence of the increasing amounts of RCM-AChR or native AChR.

Fig. $7 \mathrm{~B}$ : Dose response curve of the proliferative response in vitro to trypsinized AChR (squares) compared to native AChR (circles). Thirty-five days after immunization with $15 \mu \mathrm{g}$ native Torpedo AChR lymph node cells were cultured in the presence of the indicated amounts of trypsinized or native $\mathbf{A C h R}$.

duces high titers of antibodies which crossreact with native AChR (14-16).

Mild tryptic digestion of AChR on the other hand, does not change the functional activity of $A C h R$ (17) but alters its immunological anatomy (16). Indeed after trypsinization most antigenic determinants are removed with the exception of the MIR, when analysed with a panel of monoclonal antibodies. These monoclonal antibody mapping experiments also revealed that trypsinization removes the antigenic determinants in opposite to reduction and carboxymethylation (RCM-AChR; see Chapter IV). Trypsinized AChR still induces myasthenia while RCM-AChR does not $(15,16)$. Apparently trypsinization similarly to papain cleaves some protein bonds in $A C h R$ without profoundly altering its three dimensional structure (17). Whereas reduction and carboxymethylation induces conformational changes.

When RCM-AChR is added to lymphocytes primed in vivo with native AChR no dif- 


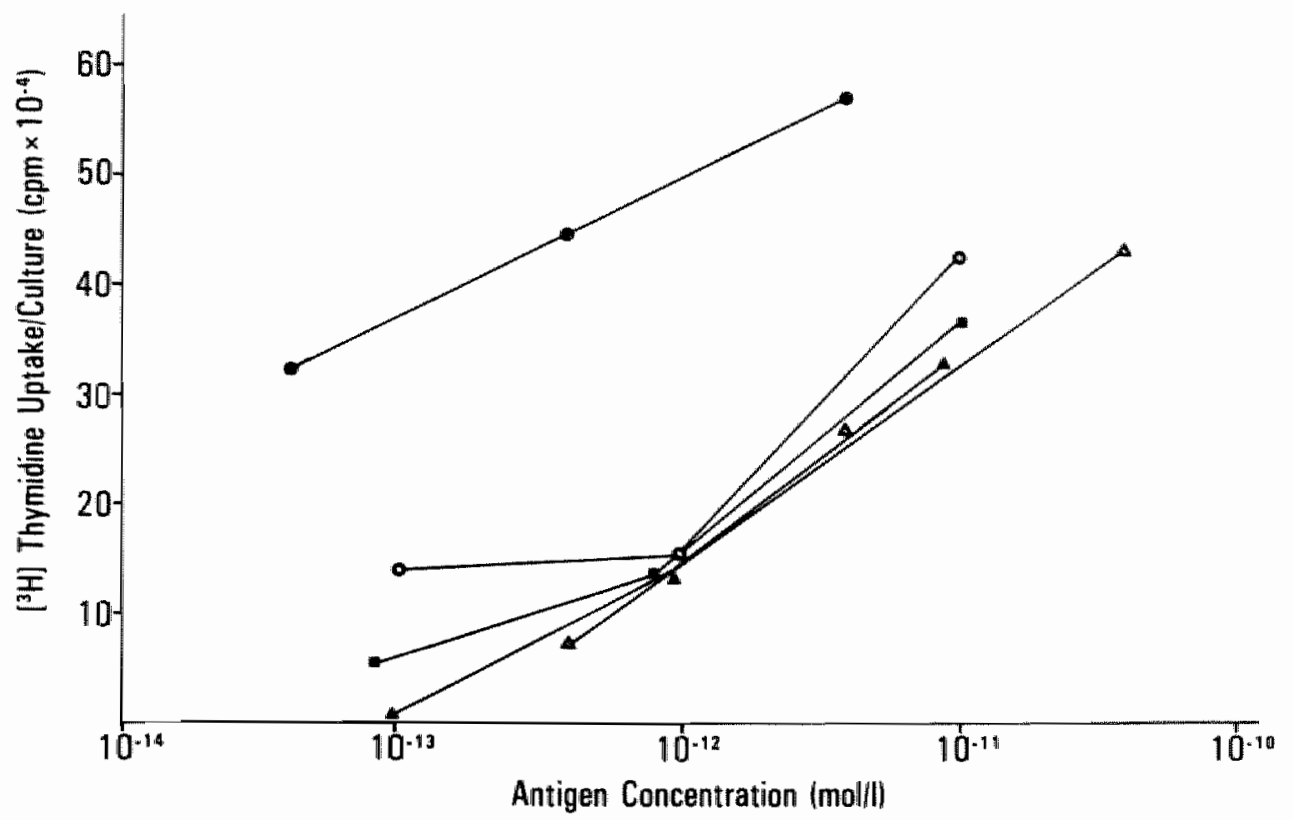

Fig. 8 : Concentration dependency of the proliferative response to denatured subunits of Torpedo $A C h R$. Note the decreased response with respect to native $A C h R$. $L y m p h$ node cells $\left(1 \times 10^{6} / \mathrm{ml}\right)$ were cultured for 5 days in the presence of increasing amounts of native $\mathrm{AChR}$ (4-400 $\times 10^{-14} \mathrm{~mol} /$ culture or denatured subunits $(\alpha, \Delta ; \beta, O ; \gamma, \boldsymbol{\Delta} ; \boldsymbol{\gamma}, \boldsymbol{\square})$. Rats were sacrificed 45 days after the primary immunization with $15 \mu \mathrm{gg}$ of Torpedo $\mathrm{AChR}$ in CFA.

ferences between native and denatured $\mathrm{AChR}$ on the proliferative response of the primed lymphocytes was observed (fig. 7A). We examined in addition the effect of the four purified receptor subunits on the proliferative response and found them to be equal on a molar basis each subunit giving a proliferative response about $50 \%$ of that induced by native $\mathrm{AChR}$ (fig. 8). Also the slopes of the dose response curve of the various subunits was similar.

Trypsinized $\mathrm{AChR}$ also induced a proliferative response of lymphocytes primed with native $\mathrm{AChR}$. The proliferative dose response curve elicited by native and trypsinized AChR were identical (fig. 7B).

Surprisingly the absence of the main immunogenic region (RCM-AChR) or deletion of antigenic epitopes outside the MIR did not influence the immunogenicity when compared to native AChR. This suggests that in our model the $A C h R$ is broken down at the level of the antigen presenting cells (e.g. macrophages) prior to presentation to the $T$ cells for the loss of the three dimensional structure of the $A$ ChR and the MIR does not influence the proliferative response of primed $\mathrm{T}$ cells. This view is supported by the fact that isolated subunits also elicit a proliferative cell responses (fig. 8). These 

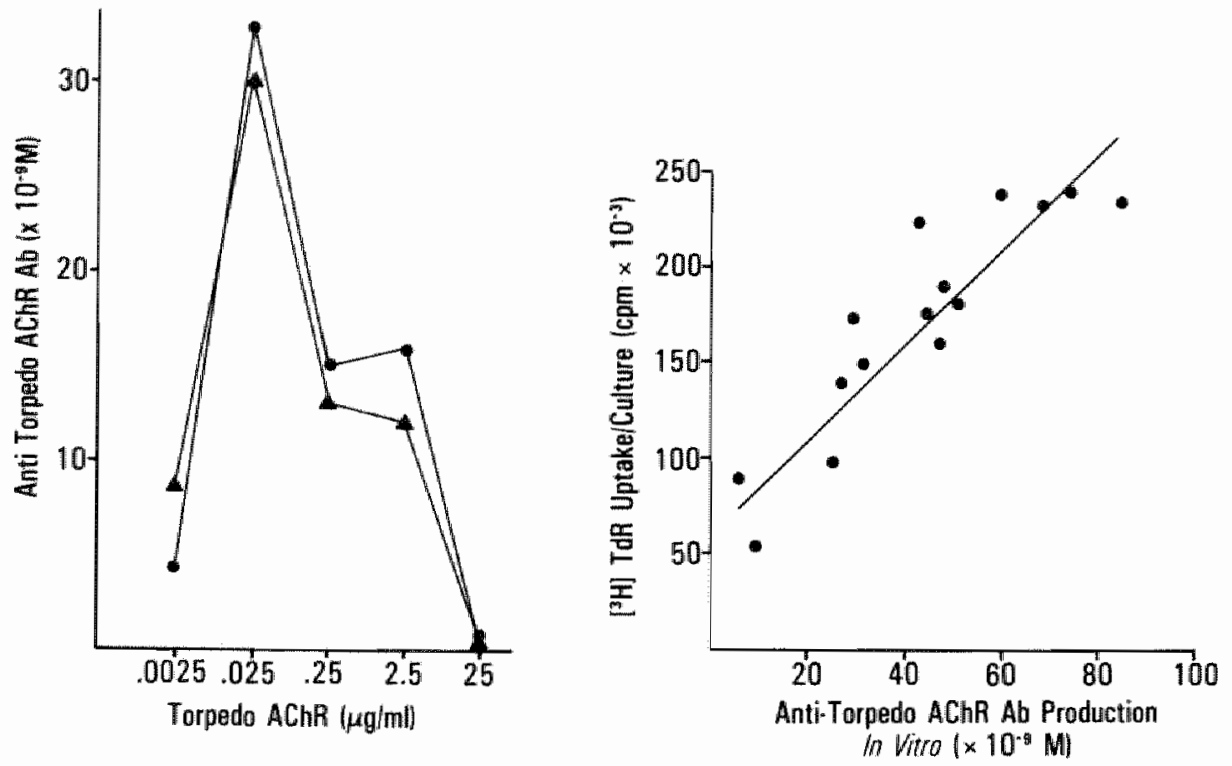

Fig. 9: AChR concentration dependency of anti-AChR antibody production in vitro. Lymph node cells were removed from rats 45 days after immunization with $15 \mu \mathrm{g}$ of Torpedo AChR and cultured for 6 days. The two symbols indicate very similar response of cells from two different rats.

fig. $10: I m$ vitro the proliferative and antibody responses are directly proportional. Lymph node cells of 15 rats immunized with $15 \mu \mathrm{g}$ Torpedo AChR with EAMG were cultured under optimal conditions for $\mathrm{T}$ cell proliferation $(2.5 \mu \mathrm{g} / \mathrm{ml})$ and for antibody production $(25 \mathrm{ng} / \mathrm{ml})$.

results were not to be expected on the basis of the antibody response elicited in wivo with native AChR which show the main autoantibody response to be directed to the MIR.

\subsection{AChR-INDUCED SPECIFIC ANTIBODY PRODUCTION IN VITRO}

\subsubsection{The effect of chemical alteration of $\mathrm{AChR}$ on the in vitro antibody production}

In the previous experiment no restriction of the $\mathrm{T}$ cell proliferation response (restriction in terms of MIR) was seen although such a restriction appears present when studying autoantibody (to native $\mathrm{AChR}$ ) in vivo. In order to elucidate this discrepancy the antibody response of lymph node cells (from rats primed with native AChR) to native and chemically modified AChR was examined in vitro. The question asked was whether or not the presence of the MIR was required to elicit an antibody response by primed lymph node cells by AChR. 


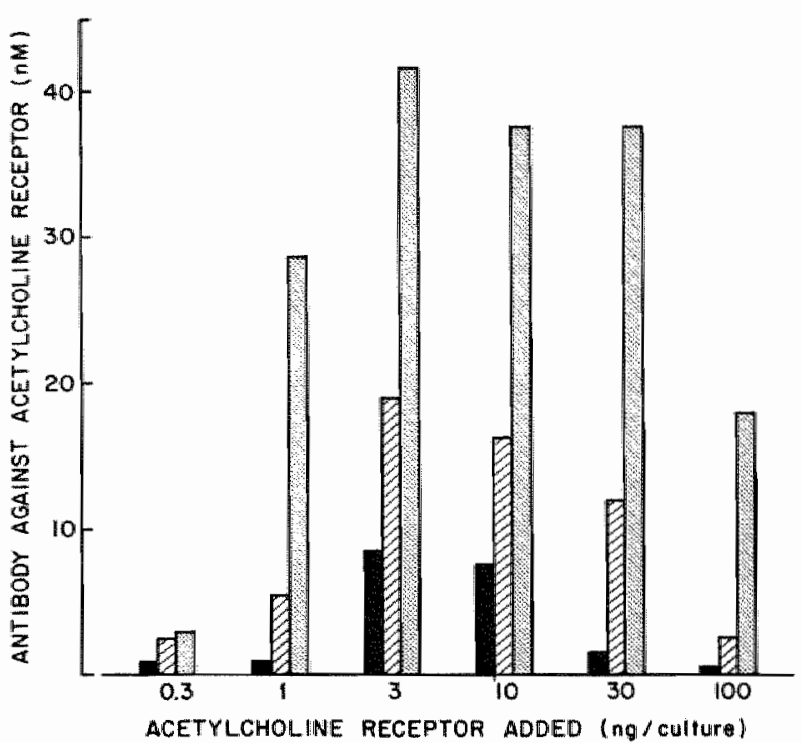

Fig. 11 : Antibody production by lymph node cells in vitro after exposure to AChR. Lymph node cells were removed from rats 5 weeks after they received a single immunization with $15 \mu \mathrm{g}$ soluble $A C h R$. The cells were cultured in the presence of the indicated concentrations of soluble $A C h \mathbb{R}$ (left bars), $A C h R$ incorporated into regular liposomes (middle bars), or $A C h R$ incorporated into liposomes supplemented with $20 \%(\mathrm{w} / \mathrm{w})$ cholesterol (right bars). The coefficient of variation between individual cultures was within $10 \%$.

Results and comments.

A dose response curve showed that addition of native AChR to primed lymph node cells elicited antibody production; maximal antibody production was observed when $25 \mathrm{ng} / \mathrm{m} \rrbracket\left(2 \times 10^{-10} \mathrm{M}\right)$ of Torpedo AChR was added. Higher dosages of receptor were inhibitory (fig. 9); The inhibition might have been nonspecific due to low levels of detergent; however the observation that much higher antigen concentrations did not inhibit thymidine incorporation (fig. 1) suggests that the inhibition may have been specific. The amount of antibody produced in vitro was directly proportional to the proliferative response of the lymph node cells (fig. 10). Reduced and carboxymethylated AChR as well as trypsinized acetylcholine receptor elicited an amount of antibody comparable to native AChR (table I). Finally AChR incorporated in artificial membranes (liposomes) were more immunogenic in terms of antibody production compared to native AChR (fig. 11). Liposomes without AChR had no effect. Inclusion of cholesterol $(20 \% \mathrm{w} / \mathrm{w})$ as a component of the AChR containing liposomes lead to a substantial additional enhancement of antibody production.

It is clear from this experiment that the antibody response elicited by adding chemically modified Torpedo californica AChR to cultures of in vivo primed lymphocytes yields 
similar results compared to the proliferation assay. The fact that proliferative response is directly proportional to the amount of antibody produced suggest the proliferating cells to be of T-helper cells. These results then suggest that the main immunogenic region or an intact three dimensional structure of $A C h R$ are not required for presumably $T$ cell mediated $-B$ cell responses. Definitive evidence for this assumption requires of course study of antibody specificity. In the culture system used the small amounts of antibody produced were not sufficient to answer this question.

Table $I$ : Anti-ACh $R$ antibody response induced in vitro by native $A C h R$, trypsinized $A C h R$ and RCM-AChR.

\begin{tabular}{|c|c|c|c|}
\hline & \multicolumn{2}{|c|}{ anti-Torpedo $\mathrm{AChR}$ antibody } & \multirow{2}{*}{$\begin{array}{l}\text { (nM) induced by } \\
\text { RCM-AChR }\end{array}$} \\
\hline & native $A C h R$ & trypsinized $\mathrm{AChR}$ & \\
\hline $\begin{array}{l}\text { animal } 1 \\
\text { animal } 2\end{array}$ & $\begin{array}{l}18.8 \pm 3 \\
8.1 \pm\end{array}$ & $\begin{array}{l}15.8 \pm 2 \\
\text { N.D. }\end{array}$ & $\begin{array}{l}\text { N.D. } \\
13.9 \pm\end{array}$ \\
\hline
\end{tabular}

a) the amount of antibody (nM) to native AChR produced in vitro by $2 \times 10^{5}$ cells was measured by radioimmunoassay (mean \pm s.e.).

\subsubsection{Immunogenicity and pathogenicity of $\mathrm{AChR}$}

In the previous experiments the immunogenicity of $\mathrm{AChR}$ from Torpedo Californica was assayed by means of (secondary) in vitro assays using chemical modifications of the AChR to determine the most immunogenic sites. These experiments were not conclusive since the fine specificities of the antibody and proliferative responses could not be determined in the system used. Clinically however immunogenicity of the receptor should be related to pathogenicity. Thus only the immune $T$ and $B$ cells that (after immunization with Torpedo AChR) crossreact with mammalian (e.g. rat) AChR determine the immunogenicity clinically.

In order to examine this question the following experiment was designed:

AChR used for immunization

Species

Torpedo californica

Fetal calf

Rat

$1 \mu \mathrm{g}$

Dose
Source of AChR used in assay systemi

$2 \times 15 \mu \mathrm{g}$

$2 \times 15 \mu \mathrm{g}$
Torpedo californica

fetal calf muscle

rat muscle

fetal calf muscle

rat muscle

Torpedo californica

rat muscle

fetal calf muscle

Torpedo californica 
Rats were immunized with equal amounts of mammalian (fetal calf muscle) or Torpedo $\mathrm{AChR}$ and the cross-reactive $\mathrm{T}$ and $\mathrm{B}$ cells were assayed as shown above. Since only a limited amount of rat muscle AChR was available only about $6 \%$ of the dose of Torpedo. AChR was used as immunogen.

\section{Results and comments.}

Immunization with a single dose of Torpedo AChR $(15 \mu \mathrm{g})$ elicits a strong antibody response $\left(5.0 \pm 0.75 \times 10^{-6} \mathrm{M}, \mathrm{n}=11\right)$ as measured by radioimmunoassay (see material and methods section, p.155). Cross-reactive antibody titers to fetal calf and syngeneic rat $A C h R$ average, $1.2 \%$ and $1.0 \%$ of the anti-Torpedo $A C h R$ titer respectively, when assayed at $1 \times 10^{-9} \mathrm{M} \mathrm{AChR}$. Cross-reaction in the proliferative response appears considerably greater (25\%) (fig. 12). Similar proliferative and serologic cross-reactivity were observed with affinity purified rat $A C h R$, but because of the limited availability of rat $A C h R$, extensive studies were not possible. (table II).

Immunization of rats with fetal calf AChR (15 $\mu \mathrm{g} \mathrm{AChR}$ in complete Freund's adjuvant injected twice, 1 month apart) induces severe EAMG. The titers of serum antibody to rat muscle $\mathrm{AChR}$ and to Torpedo $\mathrm{AChR}$ were $7.9 \pm 1.1 \times 10^{-7} \mathrm{M}$ and $1.1 \pm 0.2$ $x 10^{-7} \mathrm{M}$ respectively. These anti-Torpedo $\mathrm{ACh} \mathrm{R}$ antibody titers are significantly lower compared to animals immunized with Torpedo AChR, but these sera cross-react to a greater degree with fetal calf and rat AChR than the sera from rats immunized with Torpedo AChR. To ascertain the cross-reaction at the T cell level, lymph node cells and peripheral blood lymphocytes were allowed to proliferate in the presence of fetal calf $A C h R$ (fig. 13). The proliferative response of lymph node cells to Torpedo was only $2.7 \%$ of that to fetal calf AChR compared to a $13 \%$ cross-reaction at the antibody level. Similar results were obtained in rats immunized with syngeneic AChR showing a cross-reaction to Torpedo californica of $32 \%$ in antibody specificity and $5 \%$ of the proliferative response.

Results show the crossreactive lymphocyte proliferation and antibody responses to rat AChR to be determined by the species from which the immunogen derives. Thus Torpedo AChR elicits hardly any crossreactive antibody $(1 \%)$ but a substantial crossreactive $T$ cel proliferative response (25\%). Fetal calf $A C h R$ and rat $A C h R$ on the

Table II : Cross-reactivity of the proliferative response to $A C h R$ in Torpedo $A C h R^{a}$ induced EAMG

\begin{tabular}{lll}
\hline Torpedo $\mathrm{AChR}^{\mathrm{b}}$ & $\begin{array}{l}\text { Fetal Calf } \mathrm{AChR} \\
\text { cpm/culture }(\mathrm{m} \pm \text { S.E.) }\end{array}$ & Rat $\mathrm{AChR}^{\mathrm{b}}$ \\
$229,898 \pm 21,843$ & $23,842 \pm 4,412$ & $22,560 \pm 3,767$.
\end{tabular}

a) All animals were injected once with $15 \mu \mathrm{g}$. Torpedo AChR and sacrified 40 days later.

b) The response was measured on day 5 of culture in the presence of $2.5 \mu \mathrm{g} / \mathrm{ml}\left(2 \times 10^{-8} \mathrm{M}\right)$ of AChR from the indicated species. 

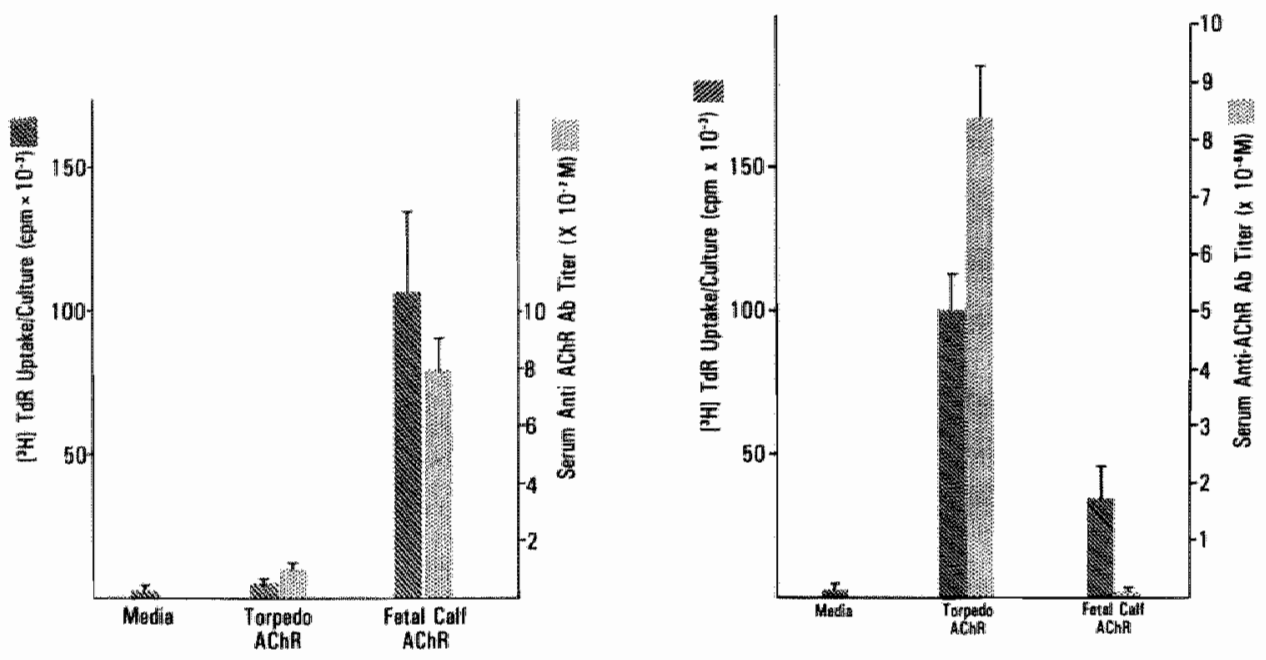

Fig. 12 : Cross-reaction of the proliferative response and serum anti-AChR of rats immunized with Torpedo AChR and stimulated with either Torpedo or fetal calf muscle AChR. Rats immunized and boosted with $15 \mu \mathrm{g}$ of Torpedo AChR were sacrificed after 39 days for lymph node cells. Both the proliferative response and the serum titers were assayed with $2.5 \mu \mathrm{g} / \mathrm{ml}$ of Torpedo or fetal calf muscle AChR $\left(2 \times 10^{-9} \mathrm{M}\right)$. In this figure antibody is assayed at the same high concentration of $A C h R\left(2 \times 10^{-8} \mathrm{M}\right)$ used in the proliferative assay, and the anti-Torpedo AChR titers divided by 1.7 to correct for the presence of dimers in Torpedo AChR, but not muscle AChR. Still the extent of antibody cross-reaction is smaller than the extent of proliferative cross-reaction $(25 \%)$.

Fig. 13 : Cross-reaction of the proliferative response and serum anti-AChR antibody of rats immunized and boosted with $15 \mu \mathrm{g}$ fetal calf muscle AChR and stimulated with either Torpedo or fetal calf muscle $\mathrm{AChR}$. The proliferative response and the serum antibody concentrations were assayed with $2.5 \mu \mathrm{g} / \mathrm{ml}\left(2 \times 10^{-8} \mathrm{M}\right)$ Torpedo or fetal calf muscle AChR. Lymph node cells taken 41 days after he initial immunization were cultured for 5 days.

other hand elicited a substantial crossreactive antibody response to Torpedo AChR $(13 \%)$ and rat AChR (32\%) respectively, but not at the level of the $T$ cells $(2.7 \%$ and $5 \%$ respectively). Thus at the level of the $\mathrm{T}$ cells no tolerance to mammalian $\mathrm{AChR}$ exists since a good $T$ cell proliferative reaction to muscle $A C h R$ occurs regardless the source of $\mathrm{AChR}$ used for immunization. In addition these experiments show that in rats, immunized with muscle $A C h R$, the restriction of the crossreaction occurs at the $T$ cell level, whereas Torpedo $A C h R$ induces a restriction at the B cell level (table III). 
Table III: Schematic representation of cross-reactivity patterns of $T$ and B cells in EAMG induced by Torpedo or rat muscle AChR.

Cross reaction of

\begin{tabular}{cccc}
\hline \multicolumn{2}{c}{ T-cells } & \multicolumn{2}{c}{ B-cells } \\
\cline { 3 - 4 } $\begin{array}{c}\text { Torpedo } \\
\text { AChR }\end{array}$ & $\begin{array}{c}\text { Mammalian } \\
\text { AChR }\end{array}$ & $\begin{array}{c}\text { Torpedo } \\
\text { AChR }\end{array}$ & $\begin{array}{c}\text { Mammalian } \\
\text { AChR }\end{array}$ \\
\hline+ & + & + & - \\
- & + & + & + \\
\hline
\end{tabular}

These differences in $T$ and $B$ cell responsiveness to self antigens are well known from other models of autoimmune disease e.g. autoimmune thyreoiditis (1). We hold that the difference between autoimmune thyreoiditis and EAMG resides in the fact that in contrast to thyroglobulin the AChR does not circulate and consequently does not maintain unresponsiveness of $T$ cells as shown by the fact that immunization with rat $A C h R$ elicits a clearcut $\mathrm{T}$ cell proliferative response.

In conclusion then, Torpedo californica $A C h R$ is a superior immunogen compared to mammalian AChR in terms of crossreactive T cell proliferation; mammalian AChR however, is the superior immunogen clinically for, although the absolute amount of antibody elicited is less compared to Torpedo AChR, the percentage crossreactivity is much greater and these antibodies are responsible for disease clinically.

\subsection{ON THE CELLULAR MECHANISMS OF THE SECONDARY IN VITRO RESPONSE TO AChR}

\subsubsection{The cellular requirements for the secondary in vitro proliferative and antibody response to $\mathbf{A C h R}$}

Our previous experiments yielded indirect evidence that antigen presenting cells were required for proliferation and that the proliferating cells were most likely $T$-helper cells. Therefore the effect of AChR on the proliferative response and antibody production of primed lymph node cells was measured after removal of accessory cells (e.g. macrophages) from the lymph node cell suspensions.

Results and comments.

Removal of $T$ cells from native AChR primed lymph node cell suspensions with a $T$ cell specific anti rat brain serum in the presence of complement resulted in a dramatic reduction of both AChR induced proliferation (fig. 14) and antibody production (Table IV) indicating that both responses were $T$ cell dependent. 


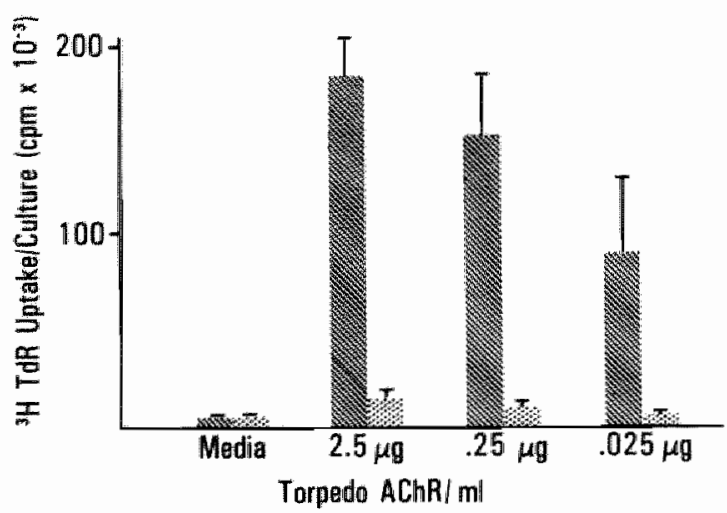

Fig. $14: T$ cell depletion inhibits the proliferative response. Five rats were immunized with 15 $\mu \mathrm{g} \mathrm{AChR}$ and sacrificed 40 to 45 days later. Lymph node cells were cultured either without (cross-thatched bars) or after treatment (stippled bars) with a rabbit anti-rat brain serum and complement.

Table IV : $\mathrm{T}$ cells are required for $\mathrm{AChR}$ induced antibody production in vitro.

\begin{tabular}{|c|c|c|}
\hline Lymph node Cell ${ }^{\mathrm{a}}$ Treatment & $\begin{array}{l}\text { Torpedo AChR } \\
(2.5 \mu \mathrm{g} / \mathrm{ml})\end{array}$ & $\begin{array}{l}\text { Anti-Torpedo } \mathrm{AChR}^{\mathrm{b}} \mathrm{Ab} \\
\left(\times 10^{-9} \mathrm{M}\right)\end{array}$ \\
\hline None & - & 0.36 \\
\hline None & + & 69 \\
\hline Anti-rat brain serum $+C^{\prime}$ & - & 0.31 \\
\hline Anti-rat brain serum $+C^{\prime}$ & + & 2.8 \\
\hline
\end{tabular}

a) The total lymph node cell population was treated with anti-rat brain serum and C' or left untreated before stimulation with $\mathrm{AChR}$.

b) The response was measured on day 6 of culture after removal of AChR by washing $24 \mathrm{hr}$ before harvesting.

Table V : W3/25-Positive cells are required for proliferation and antibody production in vitro.

\begin{tabular}{|c|c|c|}
\hline Lymph Node Celli Preparation & $\begin{array}{l}{\left[{ }^{3} \mathrm{H}\right] \mathrm{TdR} \text { Uptake }} \\
(\mathrm{cpm} / \text { culture })\end{array}$ & $\begin{array}{l}\text { Anti-Torpedo } \mathrm{AChR}^{\mathrm{c}} \\
\text { Antibody }\left(\mathrm{x} \quad 10^{-9} \mathrm{M}\right)\end{array}$ \\
\hline Unseparated & 230,455 & 34 \\
\hline W3/25 depleted & 8,421 & 0.6 \\
\hline W $3 / 25$ positive & 142,940 & 2.1 \\
\hline
\end{tabular}

i) Immune lymph node cells were incubated with anti-W3/25 monoclonal antibody and a fluoresceinated goat anti-mouse IgG rendered mouse IgG-specific by absorption on insolubilized rat $\mathbb{I g G}$. Subsequently, cell separation was performed with a fluorescence-activated cell sorter. This is one representative experiment out of 3 .

b) The response was measured on day 5 of culture.

c) Anti-Torpedo AChR antibody concentration in culture was measured on day 6 of culture after removal of the antigen by washing $24 \mathrm{hr}$ before harvesting. 
Direct evidence that the proliferating cells are of the T-helper variety was obtained by removal of $T$-helper cells with fluorescence activated cell sorting techniques as follows. Lymph node cells from rats primed with native AChR were incubated with a monoclonal mouse antibody (W $3 / 25$ ) which recognizes rat $T$-helper cells and macrophages (18); next these cells were incubated with fluoresceine labeled $F(a b)_{2}$ fragments of goat IgG anti mouse IgG. This suspension was passed through a fluorescence activated cell sorter as follows:

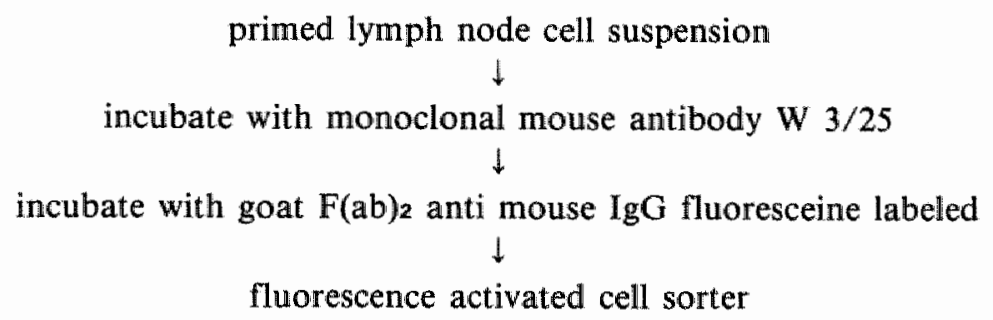

W $3 / 25$ negative population

$\downarrow$

Culture for 5 days with $\mathrm{AChR}$

measure proliferation

and antibody
W $3 / 25$ positive population

Culture for 5 days with AChR measure proliferation and antibody

Both sorted populations were brought to a cell concentration of $10^{6}$ cells $/ \mathrm{ml}$ and cultures of $2 \times 10^{5}$ cells/microwell were set up with native AChR added. Depletion of W $3 / 25$ positive cells completely abolished the proliferative and antibody response to native AChR (table V). The W 3/25 positive lymphocytes on the other hand were capable of proliferation in the presence of $\mathrm{AChR}$ but not capable of antibody synthesis, because few antibody producing cells were retained in this fraction. The proliferative capacity of the W $3 / 25$ positive population was reduced compared to the control cultures because this fraction contained no dendritic cells since these cells do not express the W $3 / 25$ phenotype (Dr. L. Nagelkerken, personal communication).

In order to demonstrate that both proliferative and antibody responses required the presence of macrophages (antigen presenting cells), primed lymph node cells were depleted of macrophages by filtration through G-10 Sephadex column (19); next cultures were set up with native $A C h R$ added.

Results (table VI) show that macrophages are required for both proliferative and antibody responses since macrophage depletion results in a reduction in $T$ cell proliferation and an even more pronounced fall in antibody production.

The results show clearly that both proliferative and antibody responses require accessory cells (macrophages) and T lymphocytes. The cell sorting experiments show that 


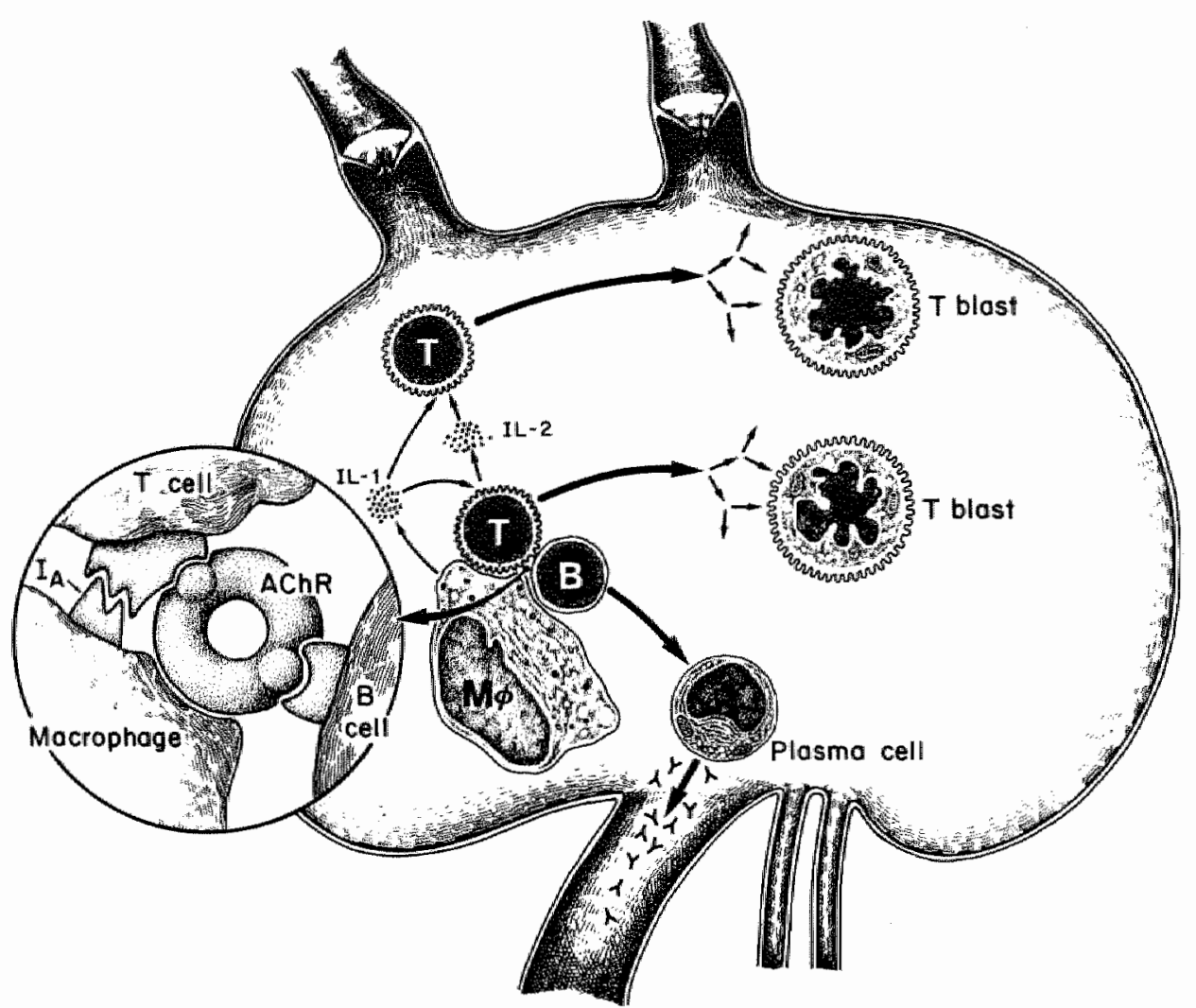

Fig. 15 : Schematic representation of the immune response to $A C h R$ in a lymph node of rats with EAMG. T and B cells recognize AChR and proliferate and differentiate into $T$ blasts and plasmacells respectively (insert). Symboles : Ia : immune response gene associated antigen; IL-1: interleukin 1; IL-2: interleukin 2.

Table VI : Macrophages are required for AChR-induced proliferative and antibody responses.

\begin{tabular}{llcc}
\hline LNC Treatment & $\begin{array}{l}\text { Torpedo AChR } \\
2.5 \mu \mathrm{g} / \mathrm{ml}\end{array}$ & $\begin{array}{l}{\left[{ }^{3} \mathrm{H}\right] \mathrm{TdR} \text { Uptake }} \\
\text { (cpm/culture) }\end{array}$ & $\begin{array}{l}\text { Anti-AChR } \\
\left(\mathrm{x} 10^{-9} \mathrm{M}\right)\end{array}$ \\
\hline None & - & 2,778 & 0.30 \\
None & + & 149,460 & 14.00 \\
G-10 filtered & - & 253 & 0.01 \\
G-10 filtered & + & 59,311 & 1.00
\end{tabular}

a) Lymph node cells (LNC) were depleted from macrophages by passage over a G-10 column.

b) Anti-Torpedo AChR antibody concentration in culture was measured on day 6 of culture after removal of the antigen by washing $24 \mathrm{hr}$ before harvesting. 
addition of native AChR to W $3 / 25$ positive cells - macrophages and T-helper cells - elicits a proliferative response. These results taken together indicate that the proliferative response of primed lymph node cells to native AChR is mediated by accessory cells (macrophages) and T-helper cells.

\subsubsection{The role of Iymphokines, specifically interleukin-2}

It is well known that T cells produce polypeptides ("interleukins") which act upon other lymphocytes and thus induce proliferation and differentiation (see figure 15). A large number of lymphokines have been described and partially characterized (20) specifically interleukin 2 (or $\mathrm{T}$ cell growth factor (TCGF)) which has been produced by means of recombinant DNA technology $(21,22)$ and is produced in the rat exclusively by T-helper cells ( $\mathbb{J}$. Rozing, personal communication). Interleukin 2 is produced by $T$-helper cells and acts on $T$ cells (inducing proliferation and differentiation) provided they have a receptor for interleukin 2 (23). The receptor for Interleukin 2 on $T$ cells is induced by antigen presenting cells (e.g. macrophages) which also secrete lymphokines called Interleukin 1 (24).

Since the proliferation and antibody response observed in our in vitro system required the presence of macrophages and $T$ cell the question asked was whether Interleukin 2 production was demonstrable in our system thus confirming the presence of $T$-helper cells.

\section{Results and comments.}

Lymph node cells of animals with EAMG were restimulated in vitro with increasing amounts of AChR under conditions as described for the T cell proliferative assay. Aliquots of the supernatants $(50 \mu 1)$ of these cultures were assayed for Interleukin-2 production by maens of a cytotoxic T cell line (CTLL cell line) that is absolutely dependent on IL-2 for its growth (see material and methods section, p.158). The amount of IL-2 present in the culture supernatants is directly proportional to the height of the proliferative response of the CTLL cell line as measured by $\left[{ }^{3} \mathrm{H}\right]-\mathrm{TdR}$ incorporation. The amount of IL-2 produced by immune lymphocyte upon additon of AChR peaks at day 3 (fig. 16). When the proliferation of immune $T$ cells reaches its maximum, IL-2 concentration decreases below detection capacity. These results suggest that IL-2 is produced and subsequently consumed by $\mathrm{AChR}$ induced $\mathrm{T}$ cell proliferation.

To demonstrate that IL-2 produced in vitro is necessary for AChR induced proliferation we added exogenous IL-2, isolated from culture of concanavalin A stimulated normal rat splenocytes (kindly donated by Dr. L. Nagelkerken, Dept. Immunology, University of Limburg, Maastricht) and IL-2 obtained by recombinant DNA technology (kindly donated by Dr. R. de Vos and Prof. W. Fiers, University of Gent, Belgium). The addition of increasing amounts of rat IL-2 purified from concanavalin-A stimulated lymphocyte supernatants, stimulates the proliferation of immune lymph node cells from animals with EAMG in the abscence of AChR (fig. 17a). In ad- 


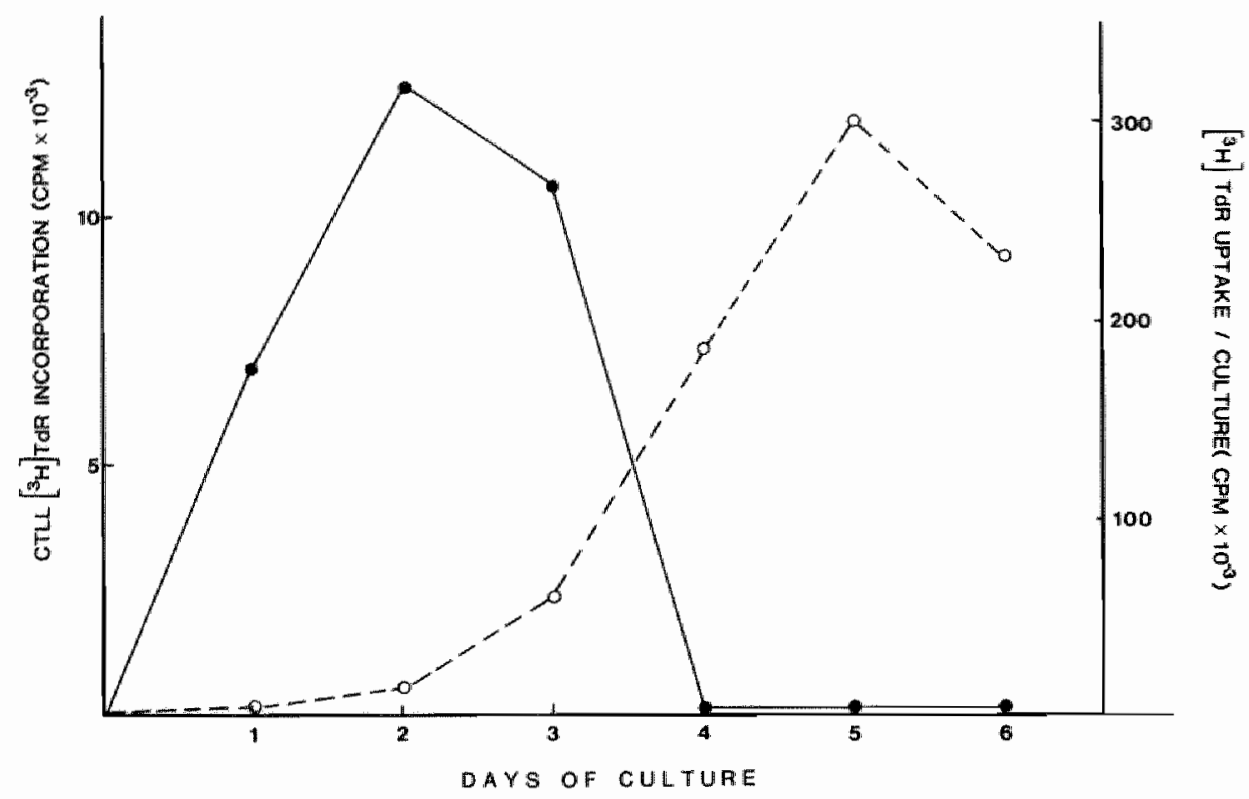

Fig. 16: Kinetics of interleukin 2 production (solid line) compared to $T$ cell proliferation (broken line). Lymph node cells $\left(2 \times 10^{5}\right.$ cells/well) were cultured for indicated time in the presence of $2,5 \mu \mathrm{g} \mathrm{AChR} / \mathrm{ml}$. Interleukin-2 production was measured by using the CTL-L cell line.

dition to proliferation these supernatants can also stimulate $\mathrm{AChR}$ specific antibody production in vitro(data not shown). Simillar results were obtained with IL-2 produced by recombinant DNA technology (fig. 17b)

It is clear from these experiments that in our culture system the amounts of endogenous produced IL-2 is rate limiting in terms of $\mathrm{T}$ helper cell proliferation since exogenous added Interleukin 2 is capable of an aspecific amplification of both proliferation and antibody production indicating the presence of an abundance of IL-2 receptors.

\subsection{DISCUSSION}

Lymph mode cells from rats with $\mathbb{E A M G}$ proliferate and differentiate into anti-AChR antibody producing cells upon stimulation with Torpedo and mammalian AChR in vitro. It is demonstrated that the cells which proliferate in vitro in response to $A C h R$ are $T$ helper cells. The evidence that they are $T$ helper cells is that:

1. they are killed by antisera to $T$ cells plus complement.

2. the cells produce interleukin-2 ( $\mathrm{T}$ cell growth factor) in vitro

3. antibody production in vitro depends on their presence

4. antibody production in vitro is proportional to their proliferative capacities.

5. they express the W3/25 antigen previously characterized in a classical adoptive transfer system as a $\mathrm{T}$ helper cell membrane marker. 

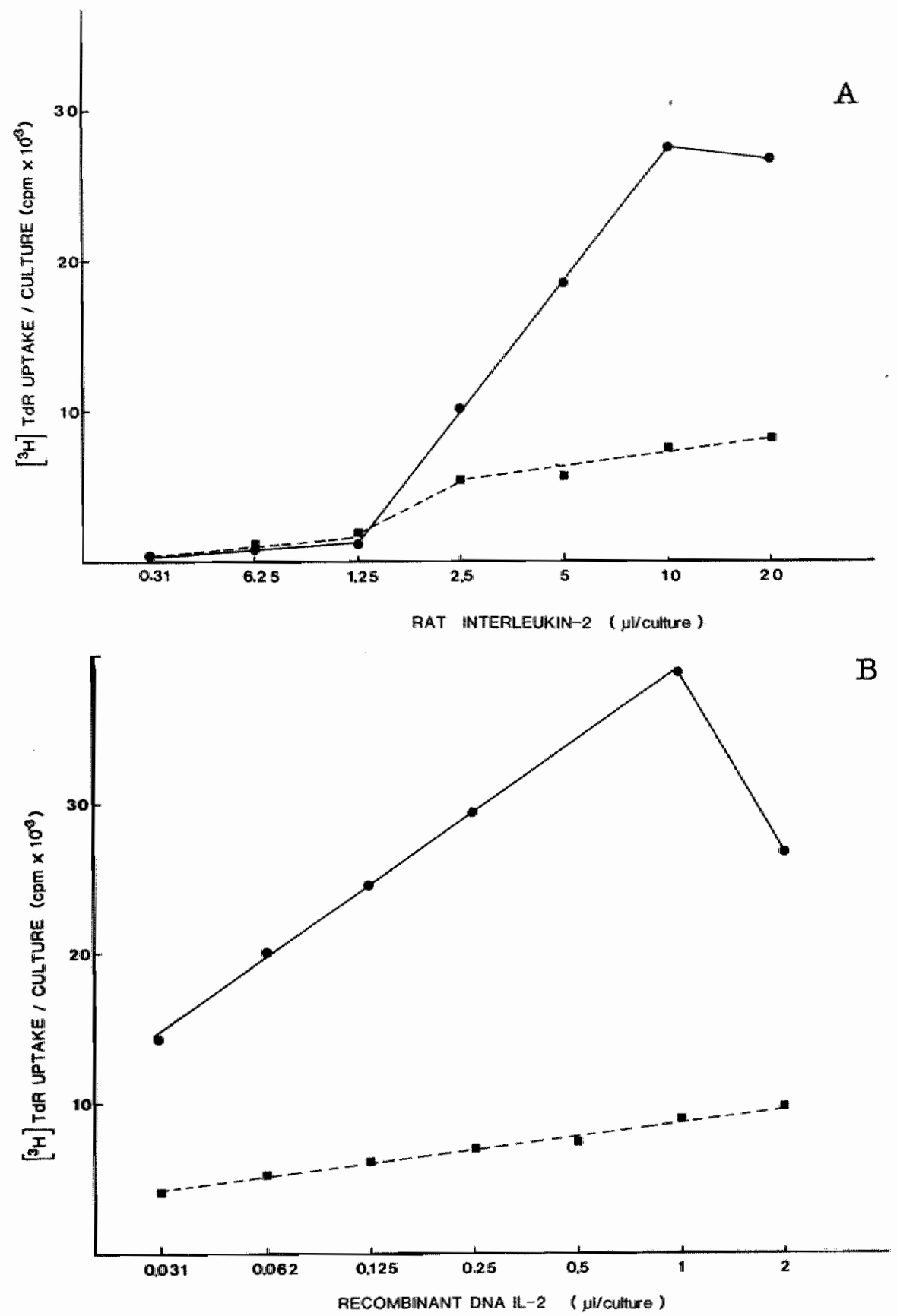

Fig. 17: Effect of Interleukin 2 on the T cell proliferative response of immune lymph node cells from rats with EAMG. Lymphocytes $\left(2 \times 10^{5}\right)$ were cultured in the presence of Interleukin 2 purified from supernatants of Con A stimulated rat spleen cells (panel $A ; 1250 \mathrm{U} / \mathrm{ml}$ ) or obtained by recombinant DNA technology (panel B; $780,000 \mathrm{U} / \mathrm{ml}$ ). T cell proliferation was measured on day 3 (solid line) and day 5 (broken line) of culture in the absence of AChR. 
Previous studies (25-27) provided only indirect evidence for the role of $T$ helper cells in $\mathrm{EAMG}$, in that no attempt was made to show the effect of depletion of $\mathrm{T}$ helper cells on antibody production to AChR in this antibody mediated disease. The proliferating $T$ helper cell is wery sensitive to $A C h R$ in vitro; only minute amounts of AChR $\left(0.5 \mathrm{ng} /\right.$ culture, i.e., $4 \times 10^{-15} \mathrm{~mol} /$ culture) are required to produce proliferation in vitro compared to $70 \times 10^{-12} \mathrm{~mol}( \pm 8 \mu \mathrm{g})$ present in the muscles of a normal rat. However, in vitro $12000 \mathrm{AChR}$ monomers are available per lymphocyte and no doubt several orders of magnitude more AChR per antigen reactive cell, because non-specific recruitment of $T$ cells can occur via lymphocytotrophic factors (28). In the systems in which other $T$ cell-dependent antigens were used, relatively large concentrations of antigen (10-500 $\mu \mathrm{g} / \mathrm{ml})$ were required $(5,29-35)$.

Chemically modified AChR i.e. reduced and carboxymethylated (RCM-AChR) or trypsinized $A C h R$ did not differ in their immunogenicity in vitro when compared to native AChR. These results were surprising in view of the fact that RCM-AChR lacks the main immunogenic region (MIR) towards which 50-70\% of the autoantibodies are directed $(36,37)$. The similarity between native and chemically modified AChRs in terms of specific $T$ cell activation is based on the notion that enzymatic processes take place in antigen presenting cells (macrophages) prior to presentation of the antigen to antigen specific $T$ ceils (38-41) such enzymatic processes lead to the loss of the three dimensional conformation of $\mathrm{AChR}$ and also of the MIR. Small protein fragments generated by trypsinization, could be utilized by macrophages and presented to specific $T$ cells. In contrast to the high identity at the $T$ cell level of these chemically modified AChR preparations a much lower cross-reaction is observed at the antibody level. As seen in fig. 8, the cross-reactivity between the isolated $\mathrm{AChR}$ subunits and native $\mathrm{AChR}$ at the $\mathrm{T}$ cell level can be as high as $60 \%$ unlike the cross-reaction at the serum antibody level $(<1 \%$ ) (33). Similar cross-reactivity patterns are seen when native and denatured cytochrome, lysozyme, insuline, myoglobin, bovine serum albumin, ovalbumin, staphylococcal nuclease, are used for in vitro activation of primed $\mathrm{T}$ cells (38-48). From these reports and our study it can be concluded that $T$ and $B$ cells differ from one another in the way they recognize native and denatured forms of antigen. An intact threedimensional structure of $\mathrm{AChR}$ is a prerequisite for $\mathrm{B}$ cell activation and the production of specific antibodies.

Lymph node cells from rats with chronic EAMG mature into anti-AChR antibody producing cells upon stimulation with native or chemically modified AChR in vitro. The elicitation of anti-ACh $\mathbb{R}$ antibody in vitro requires smaller amounts of the antigen with inhibition at higher antigen concentrations, possibly as a result of antigen blockade or suppressor generation in cultures. These observations have been confirmed by Bogen et al. in murine EAMG (49). These investigators could generate suppressor $T$ cells in cultures using high doses of $\mathrm{AChR}$. When we stimulate immune lymph node cells in vitro with optimal (i.e. low) doses of $\mathrm{AChR}$, we preferentially induce the differentiation of $T$ helper cells since the amount of antibody produced in vitro is directly proportional to the height of the proliferative response. Indeed the removal of cells expressing 
the helper phenotype W3/25 abolishes the in vitro antibody production. As seen with other $T$ cell dependent antigens, the AChR-stimulated proliferation and antibody production of primed lymph node cells in vitro as the same cellular requirements as reported for antigens not involved in autoimmune diseases (see fig. 15). The requirement of macrophages was demonstrated in two experiments. First, the proliferative and in vitro antibody responses are dependent upon their presence. Second, AChR incorporated in lipid membranes (liposomes) is accumulated by the macrophages (50). The latter probably accounts for the higher antigenic potency of $\mathrm{AChR}$ in liposomes as compared to soluble $\mathrm{AChR}$. The requirement of macrophages probably reflects the requirement for antigen presentation to $T$ cells in the context of major histocompatibility complex determinants (51) and more specifically, class II (Ia molecules) as shown for EAMG in mice (51). Indeed antibodies to Ia gene products of the immune response gene complex in the mouse attenuate both humoral and cellular responses to acetylcholine receptor both in vitro and in vivo and appears to suppress clinical manifestations of murine EAMG $(52,53)$.

Measurement of cross-reactivity of serum antibodies by radioimmunoassay and $T$ cell proliferation in vitro showed marked differences of cross reactivity at $\mathrm{T}$ and $\mathrm{B}$ cells depending upon the AChR type used for immunization. When rats are immunized with Torpedo AChR the cross-reactivity with fetal calf $\mathrm{AChR}$ at the antibody level is only $1 \%$, whereas cross-reactivity of the proliferative response is $25 \%$. In contrast, when rats are immunized with fetal calf $A C h R$, which is immunologically very similar to rat $A C h R$, the reverse cross-reactivity pattern is observed. In the latter situation considerable cross-reactivity $(13 \%)$ is observed with anti Torpedo AChR and anti fetal calf AChR antibody, whereas less cross-reactivity is seen with $T$ cell proliferation (3\%). Although the absolute levels of anti Torpedo AChR antibody and anti Torpedo AChR $T$ cell proliferation are low, these observations could best be explained by a restricted response to mammalian $A C h R$ in the rat, in which antibody is produced to a limited number of epitopes on the mammalian AChR in comparison to a more unrestricted response to the more foreign Torpedo AChR. Most of the cross-reactive epitopes between Torpedo AChR and mammalian AChR as characterized by means of monoclonal antibodies are localized on a region of that subunit $(36,37,54)$. The restrictions in the response to mammalian $\mathrm{AChR}$ are in agreement with other reports on the restrictions in the response to syngeneic thyroglobulin (55). Antibodies to thyroglobulin present in sera of patients with autoimmune thyroiditis, are directed to probably not more than four (55) or six (57) antigenic determinants. In patients with MG and rats with EAMG, the majority of autoantibodies are similarly restricted to a small region on the subunits $(36,37)$.

The analysis of the immune status of $T$ and $B$ cells against self antigens may lead to a better understanding of initial events leading to autoimmune diseases. Whether a given self antigen is vulnerable to an autoimmune attack depends on the specific immune status of T and B cells to that antigen; this, in turn, is determined by the concentration of self-antigen in the extra cellular fluid. This suggestion and the observation 
Table VI: Relationship between levels of self-proteins in the serum, immune status of $T$ and $B$ cells to autoantigens and autoimmune disease.

\begin{tabular}{|c|c|c|c|c|}
\hline \multirow{2}{*}{$\begin{array}{l}\text { experimental }{ }^{\text {a }} \\
\text { autoimmune } \\
\text { disease }\end{array}$} & \multirow{2}{*}{$\begin{array}{l}\text { autoantigen }^{b} \\
\text { (concentration) }\end{array}$} & \multicolumn{2}{|c|}{ Immune status of } & \multirow{2}{*}{$\begin{array}{l}\text { Effector } \\
\text { cells }\end{array}$} \\
\hline & & $\mathrm{T}$ cell & B cell & \\
\hline $\begin{array}{l}\text { thyroiditis } \\
\text { (EAT) }\end{array}$ & $\begin{array}{l}\text { thyroglobulin } \\
\text { (low) }\end{array}$ & TOL & IC & $\mathrm{T} / \mathrm{B}$ \\
\hline $\begin{array}{l}\text { encephalomyelitis } \\
\text { (EAE) }\end{array}$ & $\begin{array}{l}\text { myelin basic } \\
\text { protein } \\
\text { undetectable }\end{array}$ & IC & IC & $T$ \\
\hline $\begin{array}{l}\text { myasthenia } \\
\text { (EAMG) }\end{array}$ & $\begin{array}{l}\mathrm{AChR} \\
\text { undetectable }\end{array}$ & $\mathrm{IC}$ & IC & B \\
\hline
\end{tabular}

I) EAT: experimental autoimmune thyroiditis; EAE: experimental encephalomyelitis; EAMG: experimental autoimmune myasthenia gravis.

b) The degree of tolerance in both $\mathbb{T}$ and $\mathbb{B}$ cell compartments is dependent on the concentration of the self-antigen in the micro environment. For the examples given, the autoantigen concentration is low, or the autoantigen is not detectable.

9 TOL: tolerant; IC immunocompetent.

that $B$ cells require much higher concentrations of self antigen than $T$ cells for the maintenance of unresponsiveness are supported by data obtained using an experimental model of acquired tolerance against thyroglobulin. $(1,58)$. The mechanisms proposed for breaking tolerance in model autoimmune diseases are outlined schematically as follows (Table VI)

\subsection{Summary and conclusions}

In order to analyze the immune reactions involved in experimental autoimmune myasthenia gravis (EAMG) an in vitro system was developed in which sensitized lymphocyte cells from rats with chronic EAMG were cultured in the presence of differing acetylcholine receptor preparations. The proliferative cellular responses and the amount of antibody secreted in vitro were quantitated. The results obtained using this in vitro lymphocyte culture system can be summarized as follows.

1. The physicochemical form in which AChR was presented influenced its immunogenicity in vitro. AChR incorporated in liposomes - a form reminiscent of the postsynaptic membrane - elicited far greater proliferative and antibody responses compared to solubilized AChR.

2. The cellular requirements for an optimal proliferative and antibody response were defined. The culture system required $A C h R$, sensitized $T$ helper cells, antigen presenting cells (macrophages). The $T$ helper nature of the proliferating cells was suggested by the finding that they produced Interleukin 2 and by the fact that antibody producing cells required their presence and that 
the amount of antibody in vitro was proportional to the cellular proliferative responses. Conclusive evidence was derived by determining the phenotype of the proliferating cells which was that of $\mathrm{T}$ helper cells (W3/25).

3. Finally, the fine specificities of the proliferating $T$ heiper cells were determined. Most of the serum antibodies in EAMG appear to be directed against a small group of determinants on the $\alpha$-subunit of AChR, called the main immunogenic region (MIR). The $T$ cell responses however, were not directed to the MIR since a AChR preparation lacking the MIR (RCM-AChR) was equally effective as native $A C h R$ in eliciting $T$ cell proliferation. A second set of specificities were studied by comparing the immunogenicity of Torpedo, fetal calf and rat muscle $\mathrm{AChR}$ in vitro and in vivo. It was found that no tolerance at the $\mathrm{T}$ cell level $A C h R$ exist. The cross reactive $T$ cell proliferation and antibody response to rat $A C h R$ is determined by the species from which the immunogen derives.

References

1. Weigle WO. Analysis of auto immunity through experimental models of thyroiditis and allergic encephalongelitis. Adv. Immunol. 30, 159-275, 1980.

2. Mishell BB and Shiigi. Selected methods in cellular immunology. Freedman, San Francisco, 1980.

3. Mishell RI and Dution RW. Immunization of normal mouse spleen cell suspensions in vitro. Science 153: 1004, 1966 .

4. Pearmain G, Lycette RR and fitzgerald PH. Tuberculin-induced mitosis in peripheral blood leukocytes. Lancet i: 637-638, 1963.

5. Corradin $\mathrm{G}$, Etlinger HM and Chiller JM. Lymphocyte specificity to protein antigens. 1. Characterization of the antigen induced in vitro $T$ cell-dependent proliferative response with lymph node cells from primed mice. J. Immunol. 119, 1048-1053, 1977.

6. De Baets $\mathrm{MH}$, Eünarson $\mathrm{B}$, Lindstrom $\mathrm{JM}$ and Weigle WO. Lymphocyte activation in experimental autoimmune myasthenia gravis. J. Immunol. 128: 2228-2235, 1982.

7. Perper RJ, Zee TW and Mickelson MM. Purification of lymphocytes and platelets by gradient centrifugation. J. Lab. Clin. Med. 72: 842-848, 1968 .

8. Gershon RK. T cell control of antibody production. Contemp. Top. Immunobial. 3: 1 40, 1974.

9. Yowell $\mathrm{RL}$, Araneo $\mathrm{BA}$ and Sercarz EE. The fundamental $\mathrm{T}$ cell proliferative repertoire in a nonresponder strain and its qualitative alteration by suppression. $J$. Immunology 124: 2162- 2168, 1980.

10. Richert $J \mathbf{R}$, Driscoll $\mathrm{BF}$, Kies $\mathrm{MW}$ and Alword $\mathrm{EC}$. Adoptive transfer of experimental allergic encephalomyelitis: Incubation of rat spleen cells with specific antigen. J. Immunol. 122: 494-496, 1979.

11. Anholt R, Lindstrom J, Montal M. I. Biol.Chem. Stabilization of acetylcholine recepter channels by lipids in cholate solution and during reconstitution in vesicles. 256:4377.4387, 1981.

12. Anholt $R$, Fredkin $\mathrm{DR}$, Deerinck $T$, Ellisman $M$, Montal $M$ and Lindstrom J. Incorporation of acetylcholine receptors into liposomes vesicle structure and acetylcholine receptor function.. $J$. Biol. Chem. 257: 7122-7134, 1982.

13. Kistler $J_{2}$ Stroud $R$, Klymkowsky $M$, Lalancette $R$ and Fairclough $R$. Structure and function of an acetylcholine receptor. Biophys. J. 37: 371-383, 1982. 
14. Bartfeld D and Fuchs S. Immunological characterization of an irreversibly denatured acetylcholine receptor. $\mathbb{F E B S}$ letters 77: 214-218, 1977.

15. Bartfeld D. and Fuchs S. Specifie immunosuppression of experimental autoimmune myasthenia grawis by denatured acetylcholine receptor. Proc. Natl. Acad.Sci. USA 75: 4006-4010, 1978.

16. Fuchs $S$, Bartfeld D, Mochly-Rosen $D$, Souroujon $M$ and Feingold $C$. Acetylcholine receptor: molecular dissection and monoclonal antibodies in the study of experimental myasthenia. Ann. NY Acad. Sci. 377: 110-124, 1981.

17. Lindstrom $J$, Gullick $W$, Conti-Tronconi BM and Ellismam $M$. Proteollytic ricking of the acetylcholine receptor. Biochemistry 19: 4791-4795, 1980.

18. Mason DW, Brideau RJ, McMaster WR, Webb M, White RAH and Williams AF. Monoclonal anthbodies that define T-lymphocyte subsets in the rat. In: Monoclonal antibodies. Hybridornas: a new dimension in biological analysis. Kennett RH, McKearn TJ and Bechtol KB (Eds.) Plenum Press, p. 215,1980 .

19. Ly IA and Mishell RI. Separation of mouse spleen cells by passage through columns of Sephadex $\mathrm{G}-10$. J. Immunol. Methods 5: 239-247, 1974.

20. Cohen S, Pick E and Oppenheim J. (Eds.) Biology of lymphokines. Academic Press, New York, 1979.

21. Tanaguchi T, Matsui H, Fujita T, Takaoka $C_{\text {, kashima }}$, Yoshimoto R and Hamuro J. Structure and expression of cloned cDNA for human interleukin-2. Nature 302: 305-310, 1983.

22. DeVos R, Plaetinck G, Cheroutre H, Simons G, Degrave N and Tavernier J, Remaut E and Fiers W. The molecular cloning of human interleukin 2, cDNA and its expression in E coli. Nucleic Acids Res. $11(13): 4307-4323,1983$.

23. Smith KA. Interleukin 2. Ann. Rev. Immunol. 2: 319-333, 1984.

24. Oppenheim $\mathrm{J}$ and Cohen S. Interleukins, lymphokines and cytokins - section. VI Sources, Activities and characteristics of interleukin 1 and endogenous pyrogen. Academic Press, New York, 1983, p. 401-506.

25. Lennon VA, Lindstrom JM and Seybold ME. Experimental autoimmune myasthenia gravis: cellular and humoral immune responses. Ann. NY Acad. Sci. 274: 283-299, 1976.

26. Christadoss $P$, Lennon VA and David $C$. Genetic control of experimental autoimmune myasthenia gravis in mice. I. Lymphocyte proliferative response to acetylcholine receptors is under $\mathrm{H}$-2-linked Ir gene control. J. Immunol. 123: 2540-2543, 1979.

27. Christadoss P, Kcro CJ, Lennon VA and David CS. Genetic control of experimental autoimmune myasthenia gravis in mice. III. Lymphocyte proliferative response to acetylcholine receptor is dependent on Lyt-1 $+2,3$ cells. J. Immunol. 126: 1646-1647, 1981.

28. Tse HY, Schwartz RH and Paul WE. Cell-cell interactions in the T cell proliferative response. I. Analysis of the cell types in volwed and evidence for nonspecific T cell recruitement. J. Immunol.. 125: $491-500,1980$.

29. Osborne DP Jr, and Katz DH. Antigen-induced deoxyribonucleic acid synthesis in mouse lymphocytes. I. Nature and specificity of lymphocyte activation by hemocyanin and dinitrophenyl carrier conjugates. J. Immunol. 111: 1164-1175, 1973.

30. Osborne DP Jr and Katz DH. Antigen-induced deoxyribonucleic acid synthesis in mouse lymphocytes. II. Analysis of the cell populations required for and responding to antigen stimulation in vitro. $\mathrm{J}$. Immunol. 111: $1176-11184,1973$.

31. Vischer TL and Jaquet $C$. Effect of antibodies against immunoglobulins and the Theta antigen on the specific and non-specific stimulation of mouse spleen cells in vitro. Immunology 22: 259-266, 1972.

32. Lee KC, Singh B and Barton HA, Procyshyn A and Wong M. A simple reliable system for studying antigen-specific murine T cell proliferation. J. Immunol. Methods 25: 159-170, 1979.

33. Rosenwasser $\mathbb{L} J$ and Rosenthal AS. Adherent cell function in murine T lymphocyte antigen recognition. I. A macrophage-dependent $T$ cell proliferation assay in the mouse. J. Immunol. 120: 1991-1995, 1978.

34. Kagan $\mathrm{J}$ and Ben-Sasson SZ. Antigen-induced proliferation of murine T-Iymphocytes in vitro. II. Characterization of the lymphocyte culture system. J. Immunol. Methods 37: 15-27, 1980.

35. Moorhead JW, Walters CS and Claman HN. Immunologic reactions to haptens on autologous carriers. I. Participation of both thymus derived and bone marrow derived cells in the secondary in vitro response. J. Exp. med. 137: 411-423, 1973.

36. Tzartos SJ, Lindstrom JM. Monoclonal antibodies used to probe acetylcholine receptor structure: 
Localization of the main immunogenic region and detection of similarities between subunits. Proc. Natl. Acad. Sci. USA 77: 755-759, 1980.

37. Tzartos SI, Seybold ME and Lindstrom JM. Specificities of antibodies to acetylcholine receptors in sera from myasthenia gravis patients measured by monoclonal antibodies. Proc. Natl.Acad. Sci. USA 79: 188-192, 1982.

38. Benacerraf B. A hypothesis to relate specificity of $T$ tymphocytes and activity of I Region-specific Ir genes in macrophages and lymphocytes. J. Immunol. 120: 1809-1812, 1978.

39. Gell PGH and Benacerraf B. Studies on hypersensitivity. II. Delayed hypersensitivity to denatured proteins in guivea pigs. Immunology 2: 64-70, 1959.

40. Ishikaza $K$, Kishimoto D, Delesperse $G$ and King TP. Immunogenic properties of modified antigen $E$. 1. Presence of specific determinant for $T$ cells in denatured antigen and polypeptide chains. J. Imnumol. 113: 70-77, 1974.

41. Schirmacher $V$ and Wigzell $H$. Immune response against native and chemically modiffed albumins in mice. II. Effect of alteration of electric charge and conformation on the humoral antibody response and on helper T cell response. J. Immunol. 113: 1635-1643, 1974.

42. Sachs DH, Berzofsky JA, Fathman CG, Pisetsky DS, Schechter AM and Schwartz RH. The immune response of staphylococcal nuclease: A probe of cellular and humoral antigen specific receptors. Cold Springer Harbor Symp. Quant. Biol. 41: 295-306, 1976.

43. Barcinski MA and Rosenthal AS. Immune response gene control by determinant selection. I. Intramolecular mapping of the immunogenic sites on insulin recognized by guinea pig $T$ and $B$ cells. $J$. Exp. Med. 145: 726-742, 1977.

44. Corradin $G$ and Chiller $J M$. Lymphocyte specificity to protein antigens. II. Fine specificity of $T$ cell activation with cytochrome $C$ and derived peptides as antigenic probes. J. Exp. med. 149: 436 447, 1979.

45. Rosenwasser LY, Barcinsky MA, Schwartz RH and Rosenthal AS. Immune response gene control of determinant selection. II. Genetic control of the murine T lymphocyte proliferative response to insulin. J. Immunol, 123: 471-476, 1979.

46. Maizels RM, Clarke JA, Harvey MA, Miller A and Sercarz EE Epitope specificty of T cell proliferative response to lysozyme: Proliferative cells react predominantly to different determinants from those recognized by B cells. Eur. J. Immunol. 10: 509-515, 1980.

47. Berzofsky JA, Richman LK and Killon DJ. Distinct H-2 linked Ir genes control both antibody and Tcell responses to different determinants on the same antigen, myoglobulin. Proc. Natl. Acad. Sci. USA 76: 4046-4050, 1979.

48. Endres RO and Grey HM. Antigen recognition by $\mathrm{T}$ cells. II Intravenous administration of native or denatured ovalbumin results intolerance to both forms of antigen. $J$. Immunol. 125: 1521-1525, 1980.

49. Bogen $S$, Mozes $E$ and Fuchs $S$. Induction of acetylcholine receptor-specific suppression. J. Exp. Med. 159: 292-304, 1984 .

50. Poste $G$, Kirsh R, Raz A, Sone $S_{\text {, Bucana }}$, Fogler WE and Fidler $\mathbb{I J}$. Activation of tumoricidal promperties in macrophages by liposome - encapsulated lymphokines: in vitro studies. In: Liposomes and Immunobiology. Tom BH and Six HR (Eds.). Elsevier North Holland lnc., New York, 93-107, 1980.

51. Yano A, Schwart2 RH and Paul WE. Antigen presentation in the murine T lymphocyte proliferative response. I. Requirement for genetic identity at the major histocompatibility complex. J. Exp. Med. 146: 828-843, 1977 .

52. Christadoss P, Lennon VA, Krco CI and Dawid CS. Genetic control of experimental autoimmune myasthenia gravis in mice. Ill. Ia molecules mediate cellular immune responsiveness to acetylcholine receptors. J. Immunol. 128: 1141-1144, 1982.

53. Waldor MK, Subramaniam S, McDevitt $H$, Steinman $L$. In vivo therapy with monoclonal anti-1-A antibody suppresses immune responses to acetylcholine receptor. Proc. Natl. Acad. Sci. USA 80: $2713-2717,1983$.

54. Tzartos SJ, Rand DE, Einarson B and Lindstrom JM. Mapping of surface structures of Electrophorus: acetylcholine receptor using monoclonal antibodies. J. Biol. Chem. 256: 8635-8645, 1981 .

55. Nye L, Pontes de Carwalho LC and Roitt IM. Restrictions in the response to autologous thyroglobulins in the human. Clin. Exp. Immunol. 41: 252-263, 1980.

56. Roitt IM, Campbell PW and Doniach D. The nature of the thyroid autoantibodies present in patient with Hashimoto's thyroiditis. Biochem. J, 69: 248-256, 1958. 
57. Shulman $S$ and Witebsky $\mathbb{E}$. Studies on organ specificity. IX. Biophysical and immunochemical studies on human thyroid autoantibody. J. Immunol. 85: 559-567, 1960.

58. De Baets MH, Weigle WO and Lindstrom $\mathrm{JM}$. Role of the $T$ and $B$ cells in autoimmunity. In: Immunopathology. FJ Dixon, Ed. Academic Press, New York, 201-223, 1982. 


\section{CHAPTER IV}

\section{Immunogenicity and Pathogenicity of Acetylcholine Receptors in vivo studies}

\subsection{INTRODUCTION}

We have shown previously (Chapter III) that $T$ helper and B cells sensitized in vivo by immunization with acetylcholine receptor from Torpedo californica can be induced to proliferation ( $\mathrm{T}$ helper cells) and antibody secretion (B cells) in vitro provided $\mathrm{ACh} R$ and accessory cells are present. Interestingly fish acetylcholine receptor devoided of the main immunogenic region (RCM-AChR), elicited in vitro responses equal to unmodified (native) fish acetylcholine receptor (AChR). Since destruction of the main immunogenic region by reduction and carboxymethylation (RCM-AChR) from the acetylcholine receptor abolishes its capacity to elicit myasthenia gravis in vivo in rabbits (1) it is clear that these in vitro results cannot be related to pathogenicity in vivo unless antibody specificities are determined. In fact prior immunization of rabbits with reduced and carboxymethylated Torpedo californica acetylcholine receptor (RCM-AChR) has been reported to protect against the induction of experimental autoimmune myasthenia gravis (EAMG) with native AChR (1).

It is clear from the observation alluded to above that immunogenicity (ability of an $\mathrm{AChR}$ preparation to elicity a primary immune response) and pathogenicity (ability to elicit EAMG) require both precise information about the antigenic binding sites of the target organ as well as the quality and quantity of the immune reactions involved, and possibly the ability of the target organ to withstand the immunological assault.

Consequently the relationship between immunogenicity and pathogenicity of a given AChR preparation should be studied in two ways. In the in vivo approach animals are immunized with various $A C h R$ preparations and the antibody response in the serum and at the neuromuscular endplate is quantitated and related to signs of myasthenia; the assumption being that the myasthenia is brought about by antibody (2). Alternatively animals are first immunized, next the immune reactions elicited are dissected in vitro by physicochemical separation of the immune cells in order to be transferred passively in vivo to naive recipients for measuring the capacity to elicit EAMG. Although the last approach is superior in terms of yielding concise answers the logistics are prohibitive. This is so because it not only implies in vitro separation of various (in vivo) sensitized cell populations ( $\mathrm{T}$ suppressor, $\mathrm{T}$ helper, cytotoxic $\mathrm{T}$ and dellayed type hypersensitivity cells) and characterization of their "fine" specificities, but above all it requires that cell populations of defined phenotype and antigenic specificity are generated in sufficient numbers to be used in passive transfer experiments. A similar reasoning holds for antibodies which would first have to separated into diverse classes 
and subclasses and next have to be characterized in terms of antigenic specificities in order to give clear answers in passive transfer studies.

It is clear from the considerations outlined above that an abundant supply of antibodies and immune cells of known phenotype and specificity are required in order to study pathogenicity in a passive transfer model. In practice this requires the presence of libraries of monoclonal antibodies (3) and $T$ cell lines or clones (4). Recently however, the use of cloned $\mathrm{T}$ cells for studying pathogenesis of disease has been questioned and short term cultures of in vitro expanded $\mathbb{T}$ cells have been show to be superior in this regard (5).

We therefore decided to approach the problem of immunogenicity and pathogenicity in three ways. First in the experimental model we characterized native and biochemically altered immunogens and next determined in a quantitative way the antibody response elicited and its relation to the severity of the myasthenia. Next monoclonal antibodies were used in passive transfer studies in order to characterize the pathogenetically important binding sites on the neuromuscular endplate; finally, a passive transfer system using immune cells expanded in short term cultures was developed in order to verify the in vitro observation that $\mathrm{T}$ helper cells are important for the development of EAMG and in order to rule out a contribution of effector $T$ cells in mediating AChR loss.

\subsection{DESIGN OF THE EXPERIMENTS}

Experimental autoimmune myasthenia gravis (EAMG) was elicited in Lewis rats by means of active immunization and passive transfer of antibody or immune lymphocytes.

\section{Active immunization with $\mathrm{AChR}$}

Acetylcholine receptors purified from electric organs of Torpedo californica muscle, fetal calf AChR and rat muscle AChR incorporated in complete Freund's adjuvant were injected into Lewis rats. At given time intervals following immunization, sera were obtained from these animals and assayed for antibody against the immunogen and against autologous $\mathrm{AChR}$. In a separate set of experiments the in vivo immunogenicity of chemically modified AChR (reduced and carboxymethylated RCM-AChR - and trypsinized AChR) was analyzed.

\section{Passive transfer with monoclonal antibody}

Monoclonal antibodies derived from splenocytes of rats with EAMG were passively transferred into normal rats in order to elicit acute EAMG. In these experiments the role of antibody with established specificities in respect to the main immunogenic region (MIR) on AChRs was examined in terms of their capacity to induce EAMG. 


\section{Passive transfer with immune lymphocytes}

Immune lymphocytes obtained from animals with chronic EAMG were cultured in vitro in the presence of $A C h R$ in order to expand $A C h R$ specific $T$ cells following the protocol described in Chapter III (pg. 00). These cultured cells were next injected into normal Lewis rats without antigen or adjuvant and antibody titers against AChR which are a measure of $T$ helper activity on $B$ cells were assayed at regular time intervals.

In all rats treated according to these three protocols the severity of myasthenia was measured clinically and biochemically i.e. by quantitating the amount of AChR in the rats' muscles and the amount of antibody complexed to the AChR at the neuromuscular endplate.

\subsection{INDUCTION OF EXPERIMENTAL AUTOIMMUNE MYASTHENIA GRAVIS (EAMG) BY ACTIVE IMMUNIZATION WITH NATIVE ACETYLCHOLINE RECEPTOR}

\subsubsection{Immunogenicity of $\mathrm{AChR}$ and kinetics of the serum antibody response.}

Because rat $\mathrm{AChR}$ and the antibodies directed to it are the relevant auto-antigen and autoantibodies we compared the immunogenicity of rat, fetal calf and Torpedo AChR by immunizing female Lewis rats, 8 to 12 weeks of age, with $1 \mu \mathrm{g}$ of Torpedo fetal calf muscle, rat muscle AChR, given twice with a one month interval. Antibodies to the 3 immunogens were measured 5 days after the booster injection. It is clear from the results in table I that all these types of $\mathrm{AChR}$ elicit an immune response. All sera reacted better with the immunogen than with $A C h R$ from another species. Torpedo AChR is a better immunogen than mammalian AChR. The lower immunogenicity of rat $A C h R$ per mol $A C h R$ in this experiment was probably due to fragmentation of this immunogen when analyzed by analytical polyacrylamide gel electrophoreses (data not shown). Antisera raised against rat muscle $A C h R$ cross-react very well with $A C h R$ from electric organs. Thus, an important fraction of antibodies to mammalian $A C h R$ are directed against phylogenetically conservative determinants of AChR.

These findings prompted us to use Torpedo $A C h R$ for our further studies, since the electric organ is a rich source of $A C h R$, which can be prepared in its native, nonproteolyzed form. In order to characterize the chronic EAMG model, the kinetics of the antibody response elicited with Torpedo AChR was determined.

Antibody titers against Torpedo AChR and rat AChR were measured in 4 rats at several time points after immunization with $15 \mu \mathrm{g}$ Torpedo AChR incorporated in complete Freund's adjuvant (CFA). The primary immune response reached a maximal antibody concentration about 20 days after immunization (fig. 1A). The titer against rat AChR ranged between 0.5 to $1 \%$ of that to Torpedo $\mathrm{AChR}$ with an immunizing dose of $15 \mu \mathrm{g}$ Torpedo AChR. The kinetics of the immune response show that the titer of 

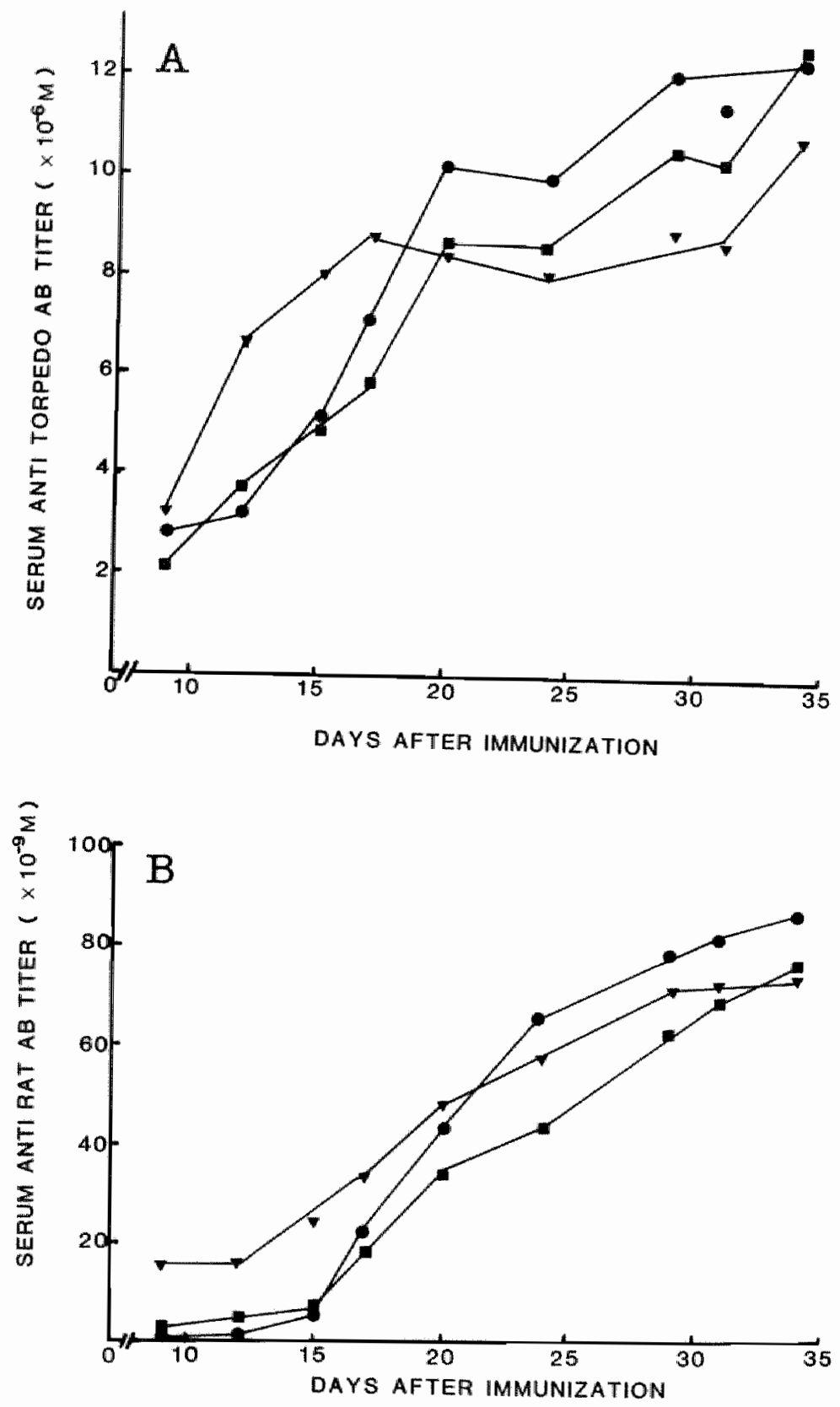

Fig. 1: Kinetics of the immune response against Torpedo and rat AChR. These rats were immunized once with $15 \mu \mathrm{g}$ Torpedo AChR. Anti Torpedo AChR (panel A) and anti rat antibody titers (panel B) were measured at given time intervals after immunization. Note the difference in scalle between anti-Torpedo and anti-rat antibody titers. 
Table I: Cross reactive antibody and acetylcholine receptor immunogenicity

\begin{tabular}{lllll}
\hline $\begin{array}{l}\text { Acetylcholine } \\
\text { receptor }\end{array}$ & $\begin{array}{l}\text { no. } \\
\text { rats }\end{array}$ & \multicolumn{3}{l}{ Antibody titer in $\mathrm{nM} /$} \\
\cline { 2 - 5 } & & Torpedo & fetal calf & rat \\
\hline Torpedo & 4 & $54.6 \pm 8.2$ & N.D. & $.30 \pm .08$ \\
Fetal calf & 5 & $16.9 \pm 9.0$ & $28.1 \pm 1.0$ & $5.3 \pm 3.0$ \\
Rat & 4 & $.45 \pm .11$ & $.68 \pm .02$ & $.84 \pm .13$ \\
\hline
\end{tabular}

Female LEW rats, 8 to 12 weeks of age, were immunized with $1 \mu \mathrm{g}$ of AChR given on days 1 and 30; animals were bled on day 35 and antibody to AChR was quantitated (mean \pm S.D.). Anti-Torpedo AChR antibody titers were divided by 1.7 to correct for the presence of dimers.

antibodies against rat $\mathrm{AChR}$ is still increasing at day 35 whereas anti Torpedo $\mathrm{AChR}$ antibodies reach a plateau at day 20 after immunization (fig. 1B).

The differences in kinetics between serum antibodies against Torpedo $A C h R$ and self AChR suggest that cross-reactive antibodies are produced later in time. It cannot be excluded that the delay is due to $\mathrm{AChR}$ at the neuromuscular endplate acting as an in vivo immunoabsorbent.

\subsubsection{Binding of antibody cross-reactive with muscle AChR to the endplate}

The differences in kinetics of antibodies to Torpedo and muscle AChR suggested that cross-reactive antibody bound to the neuromuscular endplate might be related to the pathogenesis of the myasthenia. Therefore the next experiment was designed to relate the presence of (cross-reactive) antibody bound to the neuromuscular endplate with signs of myasthenia gravis.

\section{Results and comments.}

A group of nine animals was immunized twice with $15 \mu \mathrm{g} \mathrm{AChR}$ incorporated in CFA with an interval of 30 days. Five days after the booster injection only one animal (no. 1) showed discrete signs of myasthenia clinically. All animals were sacrificed 5 days after the booster injection. As seen in table II the amount of AChR extracted from the myasthenic rats' muscles is reduced by $60 \%$ compared to the AChR concentration in rats injected with CFA alone. About one half of the AChRs in the myasthenic rats" muscles are complexed with antibody.

It is clear from this study that (cross-reactive) antibody is demonstrable at the neuromuscular junction complexed to the receptor; this antigen-antibody interaction at the neuromuscular endplate is associated with a marked decrease in acethylcholine receptor concentration with or without clinical signs of myasthenia. The receptor loss is brought about by antibody mediated increased receptor turnover $(6,7)$ and antibody 
Table II Rats with chronic EAMG* have reduced amounts of extractable AChR in their muscles.

\begin{tabular}{|c|c|c|c|c|}
\hline $\begin{array}{l}\text { Animal } \\
\text { number }\end{array}$ & $\begin{array}{l}\text { AChR concen- } \\
\text { tration per } \\
\text { animal (pmol) }\end{array}$ & $\%$ AChR loss & $\begin{array}{l}\text { Antibody-AChR } \\
\text { complexes } \\
\text { (pmol per rat) }\end{array}$ & $\begin{array}{l}\text { Serum anti } \\
\text { rat } \mathrm{AChR} \text { titer } \\
\text { (n } \mathrm{Mol} / \mathrm{l} \text { ) }\end{array}$ \\
\hline 1 & 20 & 72 & $\mathbb{1 3}$ & 25 \\
\hline 2 & 25 & 65 & 10 & 43 \\
\hline 3 & 32 & 56 & 22 & 13 \\
\hline 4 & 38 & 49 & 21 & 79 \\
\hline 5 & 27 & 64 & 10 & $\mathbb{1 1 0}$ \\
\hline 6 & 22 & 69 & 15 & 102 \\
\hline 7 & 37 & 50 & 16 & 104 \\
\hline 8 & 38 & 49 & 22 & 36 \\
\hline 9 & 24 & 67 & 22 & 119 \\
\hline$\overline{\bar{m}} \pm$ S.E. & $\overline{29} \pm 2.4$ & $\overline{60} \pm 3.1$ & $\overline{17} \pm 1.7$ & $\overline{70 \pm 14}$ \\
\hline
\end{tabular}

*) All animals were immunized twice with $15 \mu \mathrm{g} \mathrm{AChR}$ incorporated in CFA at day 1 and day 30. The rats were sacrificied 5 days after the last booster injection. Only one rat (no. 1) showed signs of myasthenia clinically.

a) The $\mathrm{AChR}$ concentration of age matched control rats injected with CFA alone is $71 \pm 3$ pmol $(n=4)$.

b) Amount of $\mathrm{AChR}$ loss versus control animals.

9) Amount of anti $A C h \mathbb{R}$ antibody complexed with $A C h R$.

mediated complement dependent receptor destruction $(8,9,10)$. It is clear from this experiment that the biochemical quantitation of receptor loss rather than the clinical symptoms is a better parameter for establishing the presence or absence of EAMG, for clinically myasthenia is only apparent when over $70 \%$ of the receptors are lost, whereas biochemically all animals suffered from substantial losses of AChR. Results obtained in this experiment are in agreement with experiments of Lindstrom et al.(11, 12) using eel acetylcholine receptor. This was to be expected since the antigenic structure of AChR from electric eel and Torpedo californica is very similar (13).

\subsubsection{Dose dependency of the immune response against $\mathrm{AChR}$ and myasthenia}

In the previous experiment an immunizing dose of $15 \mu \mathrm{g}$ Torpedo californica $\mathrm{AChR}$ given twice, 30 days apart, caused invariably a loss of AChR at the neuromuscular junction when measured 5 days after the booster injection. We hold this receptor loss to be brought about by antibody cross reactive with rat AChR. The finding at the time of sacrifice of appreciable amounts of $\mathrm{AChR}$ at the neuromuscular junction not covered with antibody is not in contradiction with this view; for the presence of high titer crossreactive antibody in the serum cannot be taken to indicate that conditions of relative antibody excess have to be present at the site of the endplate. This is so because 
transcapillary passage of IgG molecules, their transit through the negative charged interstitial colloidal matrix (14), the capacity of the neuromuscular endplate to interiorize antigen/antibody complexes and generate new receptors are all (unknown) variables which determine at the site of interstitial fluid bathing the neuromuscular junction conditions of relative antibody excess. It is clear from direct measurements that the protein concentration of the interstitial fluid of the limb musculature is well below that of serum and about 1 to 2 gram per liter (15) with - compared to serum - an increase in the albumin/globulin ration (16).

For this reason we decided to test the hypothesis that EAMG is mediated by crossreactive antibody in an indirect way by means of a dose response curve. Assuming that the "local factors" alluded to above are rather fixed variables, a direct relationship between the concentration of crossreactive antibody in the serum and a loss of AChR at the neuromuscular junction would support this hypothesis that myasthenia is brought about by crossreactive antibody.

\section{Results and comments.}

Fifteen rats, divided in 3 groups of 5 animals were immunized once with respectively 5, 10 and $20 \mu \mathrm{g}$ Torpedo AChR incorporated into CFA. Serum titers of anti Torpedo AChR antibody were determined by radioimmunoassay on days 30,37 and 41 after the initial immunization. The serum antibody titers against Torpedio and rat AChR increased with the amounts of AChR used for immunization (fig. 2) and reached a plateau between 30 and 41 days after immunization. In some animals the antibody titer was already declining at day 41 . The animals were sacrificed 41 days after the initial immunization except for one animal (no.14) which died at 39 days from severe myasthenia. All animals had reduced amounts of AChR in their endplates indicating that all rats had albeit varying degrees of myasthenia (fig. 3). The loss of AChR depended on the dose of immunogen used; animals immunized with $10 \mu \mathrm{g}$ of Torpedo AChR showed 1.5x more loss of $\mathrm{AChR}$ at the neuromuscular junction compared to those rats injected with $5 \mu \mathrm{g}$. $(P<0.05)$. Animals immunized with $20 \mu \mathrm{g}$ showed a receptor loss exceeding that of $10 \mu \mathrm{g}$ with one animal dying from severe myasthenia indicating a receptor loss well over $70 \%$ (n.s.). That the receptor loss was mediated by crossreactive antibody and dependent on the total amount of circulating crossreactive antibody present is suggested by finding a direct relationship between anti-AChR antibody bound at the neuromuscular junction and total circulating antibody (fig. 4.). These results prove a direct relationship between cross-reactive antibody in the intravascular compartment and local binding capacity at the site of the endplate over a wide range of serum antibody concentrations. These results are compatible with the view that cross-reactive antibody mediated the myasthenia. 


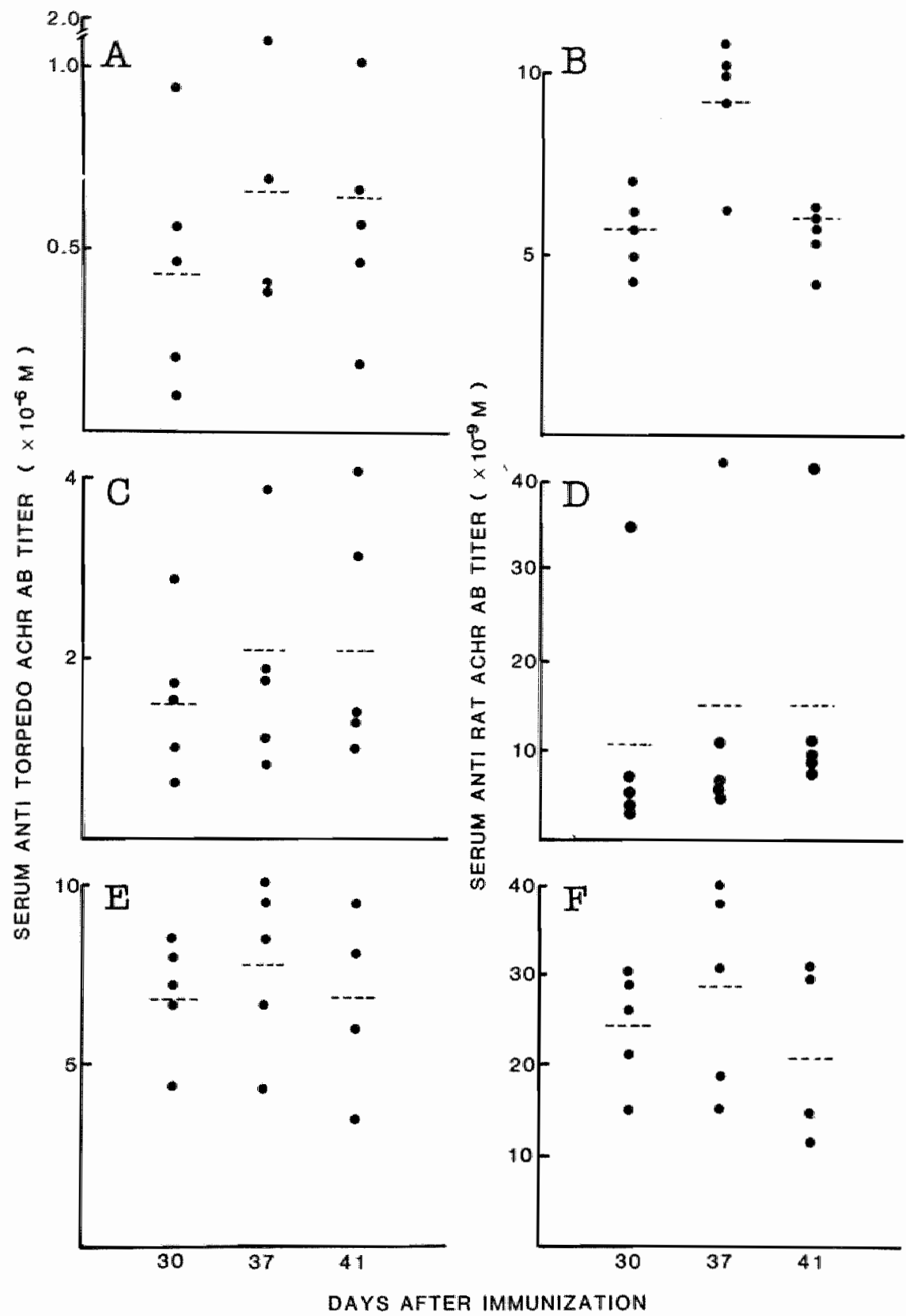

Fig. 2: Kinetics of the immune response against Torpedo $A C h R$ in animals with chronic EAMG. Three groups of five animals were immunized with 5 (A,B), 10 (C,D) and $20 \mu \mathrm{g}(\mathrm{E}, \mathrm{F})$ of Torpedo AChR respectively. Antibody titers against Torpedo AChR (A, C, E) and rat $\mathrm{AChR}(\mathrm{B}, \mathrm{D}, \mathrm{F})$ were assayed at the indicated time points after immunization. 


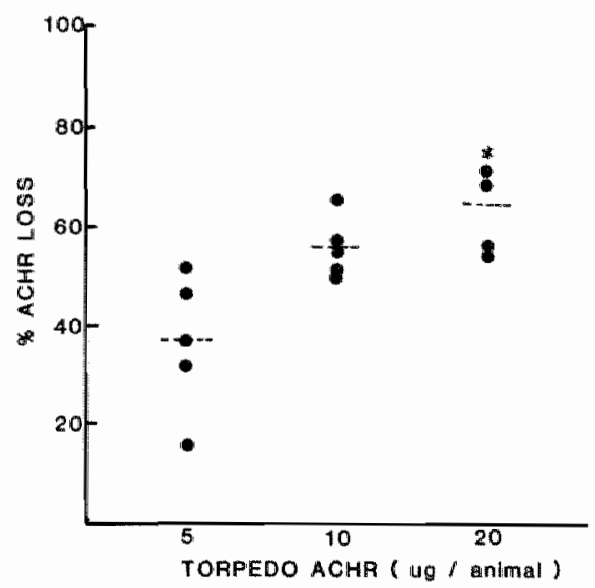

Fig. 3: Comparison between the immunizing dose of $\mathrm{AChR}$ and the severity of myasthenia. Three groups of five rats immunized with 5,10 and $20 \mu \mathrm{g}$ AChR respectively were sacrificed 42 days after immunization with Torpedo AChR. Loss of AChR from muscle was used as an index of severity of EAMG. The asterix indicates an animal that died from EAMG, it was assumed that AChR loss is greater than $70 \%$.

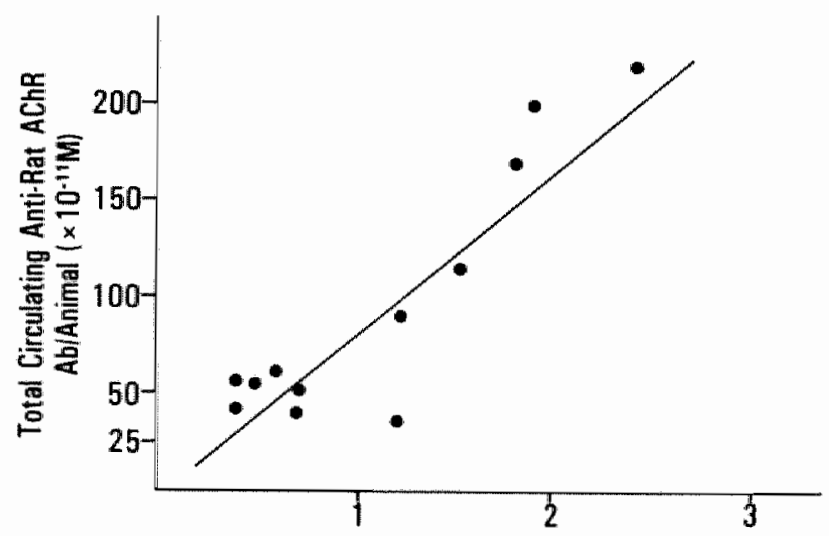

Anti AChR Antibody Bound to Muscle $\left(\times 10^{-11} \mathrm{M}\right)$

Fig. 4: Comparison between the concentration of antibody to $\mathrm{AChR}$ in serum and the amount of antibody bound to muscle AChRs in vivo. The same rats were studied as in figure 3.

\subsection{THE ROLE OF THE MAIN IMMUNOGENIC REGION IN EAMG}

In order to relate cross-reactive antibody specificity to pathogenicity the Torpedo californica AChR was first altered biochemically in such a way that deletion of antigenic sites within the main immunogenic region or outside was accomplished. Next, these altered AChR were assayed in vivo for immunogenicity and pathogenicity. 


\subsubsection{The antigenic anatomy and physicochemical characteristics of biochemically altered $\mathbf{A C h R}$}

Native Torpedo AChR was reduced and carboxymethylated (RCM-AChR) as described in material and methods section (p.151). Torpedo AChR was also subjected to mild proteolysis with trypsin ( $\mathrm{t}-\mathrm{AChR}$ ) in such a way (see material and methods) that the subunit structure as well as the mollecular morphology (17) does not change. In order to show RCM-AChR was still intact after reduction and carboxymethylation native and RCM-AChR were labeled with $\mathbf{I}^{125}$ (see material and methods) and analyzed for molecular weight by exclusion chromatography using high performance liquid chromatography on a TSK 4000 column with the appropriate precolumn (Beckman). As seen in fig. 5A/B I $^{125}$-native AChR consists mainly of AChR dimers (D) with some monomers $(M)$; the dimer peak is preceded by some aggregates (between 15 and 20 minutes). $I^{125}$ RCM-AChR shows essentially the same profile but contains somewhat more aggregates and degradation products (fig. 5B). Thus, reduction and carboxymethylation does not dissociate $\mathrm{AChR}$ into its subunits. In order to analyse the antigenic differences between native $A C h R$ and RCM-AChR we used a panel of 29 monoclonal antibodies (see material and methods section, p.159). These monoclonal antibodies were derived from rats immunized with native, SDS denatured individual subunits of AChR. The specificites of some of these monoclonal antibodies were already determined by Tzartos et al. in terms of their reactivity with the MIR, isotype and crossreaction with mammalian AChR and is specified in the material and methods section.

\section{Results and comments.}

The mapping experiments were performed by radioimmunoassay (see material and methods section) at an $\mathrm{AChR}$ concentration of $1 \mathrm{nM}$ and antibody concentrations of $3 \mathrm{nM}$ in $1 \mathrm{ml} \mathrm{0.5 \%}$ Triton X-100-PBS-NaN3. The results are expressed as:

net $\mathrm{cpm}{ }^{125}$ I- $\alpha$-bungarotoxin-RCM-AChR precipitated

net $\mathrm{cpm}^{125} \mathrm{I}-\alpha$-bungarotoxin native AChR precipitated. × 100

Parallel experiments were performed using AChR subjected to partial proteolysis using trypsin. The results with $t-A C h R$ were likewise expressed as:

net $\mathrm{cpm}{ }^{125} \mathrm{I}-\alpha$-bungarotoxin-t-AChR precipitated net $c$ pm ${ }^{125} \mathrm{I}-\alpha$-bungarotoxin-native $\mathrm{AChR}$ precipitated.

As seen in fig. 6 (right panel) 9 out of 29 monoclonal antibodies bound well to RCMAChR, three bound moderately and 17 did not bind to RCM-AChR. The polyclonal antibody, which was obtained by pooling the serum of a large number of rats with EAMG, precipitated only $40 \%$ of the ${ }^{125} \mathrm{I}-\mathrm{RCM}-\mathrm{AChR}$. Thus in the polyclonal 

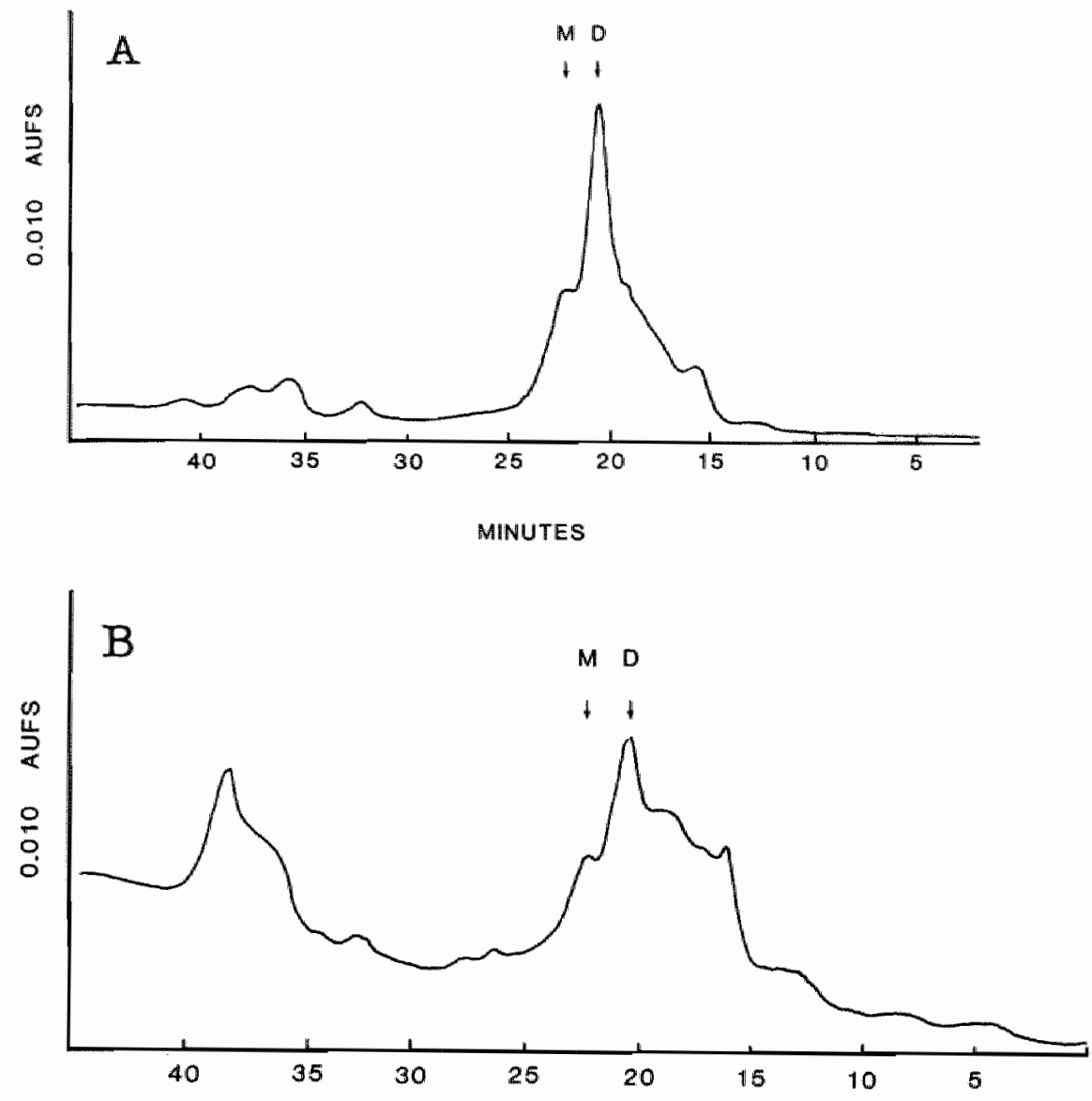

MINUTES

Fig. 5: HPLC profile of native AChR (panel $A$ ) and reduced and carboxymethylated $A C h R$ (RCM-AChR, panel B). A $20 \mu$ sample was injected and eluted with $0.2 \%$ cholate-PBS buffer $\mathrm{pH} 7.4$ with a flow $0,4 \mathrm{ml} / \mathrm{min}$. Absorption was set at 0.01 AUFS.

Symbols: D: AChR dimers, M: AChR monomers.

response against native $A C h R$ only $40 \%$ of the antibodies were directed against RCM-AChR.

Surprisingly the results obtained with trypsinized-AChR (t-AChR) are the opposite of those with $\mathrm{RCM}-\mathrm{AChR}$ with an exception for the determinants recognized by monoclonal antibody 61 that is absent on both $t-A C h R$ and RCM-AChR. Fifteen monoclonals bind well, one moderate and 13 do not bind $t-A C h R$ (fig. 6, left panel). Seventy five procent of the polyclonal antibodies reacted with $\mathrm{t}-\mathrm{AChR}$. 
TRYPSINISED-ACHR

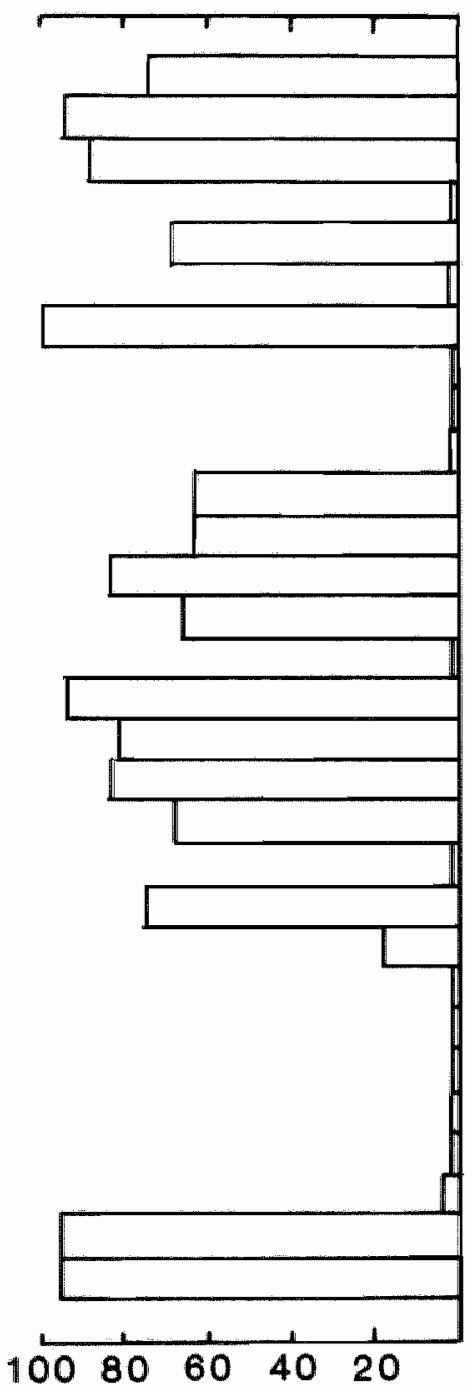

RCM ACHR

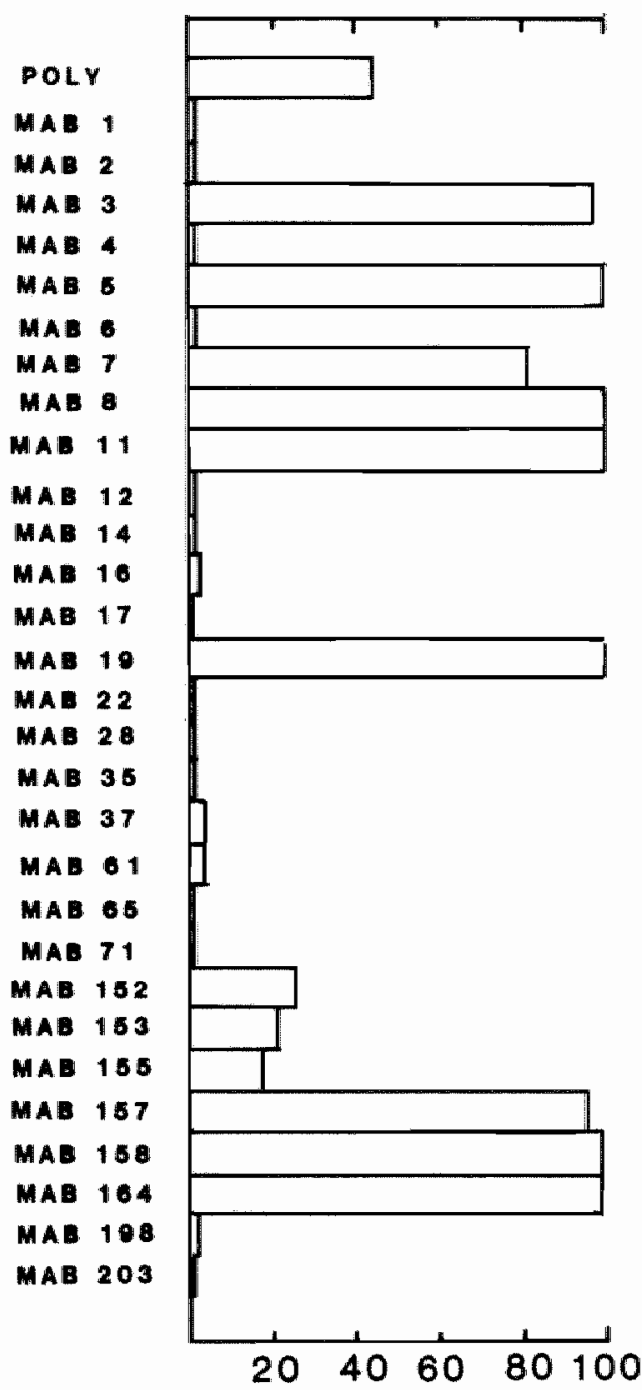

\section{\% OF ANTIBODY BOUND}

Fig. 6: Analysis of antigenic structure of t-AChR (left panel) and RCM-AChR (right panel) by means of a panel of monoclonal antibodies. The relative amount of monoclonal or polyclonal (EAMG serum) antibody bound to either t-AChR and RCM-AChR is expressed as a percentage compared to the binding of that antibody to native AChR. 
The combined results obtained with RCM-AChR and t-AChR are interesting in several aspects. First, reduction and carboxymethylation - a procedure that destroys conformational dependent determinants - has an opposite effect compared to trypsinization, a procedure that probably removes linear polypeptides in between conformational dependent determinants. Second, RCM-AChR lacks the MIR whereas t-AChR probably contains the MIR only. Finally, the results obtained with polyclonal antibodies suggest that $75 \%$ of the polyclonal antibody response is directed against the MIR which is in agreement with monoclonal antibody blocking experiments reported by Tzartos et al. $(18,19)$.

\subsubsection{Immunogenicity and pathogenicity of RCM-AChR}

In order to assess the importance of the main immunogenic region (MIR) on $A C h R$ in the rat model for EAMG, female LEW rats were immunized with Torpedo RCM$\mathrm{AChR}$ in CFA and the crossreactive antibody in the serum, as well as receptor density at the neuromuscular junction was measured.

\section{Results and comments.}

Female LEW rats (no. 1 through 5) were immunized with $15 \mu \mathrm{g}$ Torpedo RCM-AChR in complete Freund's adjuvant on day 1 and 30; positive controls were female rats immunized with native Torpedo AChR (rats no. 6 through 8) and negative controls were rats (rats no. 9 through 11) immunized with CFA only (see table III). Animals were sacrificed at $\mathbf{4 2}$ days after the primary immunization.

Rats immunized with RCM-AChR showed serum antibody concentrations against Torpedo and rat AChR of $2.7 \pm 4 \mu \mathrm{M}$ and $353 \pm 69 \mathrm{pM}$ respectively. The antibody concentration of antibodies crossreactive with rat AChR of rats immunized with native Torpedo AChR was $760 \pm 41 \mathrm{pM}$. Thus, deletion of the MIR reduced the crossreactive antibody elicited by (denatured) Torpedo AChR about 50\%. None of the rats immunized with RCM-AChR showed acetylcholine receptor loss (table IV), although compared to animals immunized with native Torpedo AChR greater quantities of antibodies were complexed to the receptor at the neuromuscular junction. $(p<0.02)$ Surprisingly rats immunized with native as well as denatured (RCM-AChR) Torpedo AChR show crossreactive antibody bound to the neuromuscular junction; this is associated with receptor loss (and thus EAMG) in rats immunized with native $\mathrm{AChR}$ only. These results can be interpreted in several ways. First, the crossreactive antibodies elicited by RCM-AChR bind to sites outside the MIR on the extracellular side of AChR, since RCM-AChR lack this antigenic determinant. Antibodies as well as MABs with this specificity are less likely to cause receptor aggregation (20). The results of Bartfeld and Fuchs (24) who found a protective effect in rabbits on EAMG by prior immunization with RCM-AChR are compatible with this view. The second explanation is that the crossreactive antibodies elicited by RCM-AChR bind to intracellular determinants not accesible in vivo (22). In this view crossreactive antibodies raised against 
Table III RCM-AChR does not induce EAMG

\begin{tabular}{|c|c|c|c|c|c|c|}
\hline \multirow{2}{*}{$\begin{array}{l}\text { Rat } \\
\text { no. }\end{array}$} & \multicolumn{2}{|c|}{ AChR type } & \multirow{2}{*}{$\begin{array}{l}\text { AChR conc/ } \\
\text { pmol/animal }\end{array}$} & \multirow{2}{*}{$\begin{array}{l}\text { \% } \mathrm{AChR} \\
\text { loss }\end{array}$} & \multirow{2}{*}{$\begin{array}{l}\text { Anti-AChR } \\
\text { complexed } \\
\text { pmol/animal }\end{array}$} & \multirow{2}{*}{$\begin{array}{l}\% \text { ab } \\
\text { complexed } \\
\text { to AChR }\end{array}$} \\
\hline & Ist injection & Boost & & & & \\
\hline 1 & $\mathrm{RCM}$ & $\mathrm{RCM}$ & 63 & 0 & 21 & 33 \\
\hline 2 & RCM & RCM & 74 & 0 & 24 & 37 \\
\hline 3 & $\mathrm{RCM}$ & $\mathrm{RCM}$ & 73 & 0 & 30 & 41 \\
\hline 4 & $\mathbb{R C M}$ & RCM & 75 & 0 & 36 & 48 \\
\hline 5 & $\mathrm{RCM}$ & RCM & 80 & 0 & 43 & 53 \\
\hline 6 & native & native & 38 & 36 & 8,7 & 23 \\
\hline 7 & native & native & 31 & 47 & 14 & 45 \\
\hline 8 & native & native & 24 & 59 & 13 & 54 \\
\hline 9 & CFA & CFA & 69 & 0 & 0 & 0 \\
\hline 10 & CFA & CFA & 55 & 0 & 0 & 0 \\
\hline 11 & CFA & CFA & 53 & 0 & 0 & 0 \\
\hline
\end{tabular}

Female LEW rats were immunized at days 1 and 30 and sacrificed 42 days after the 1 st injection. Both native and RCM AChR were given in complete CFA $15 \mu \mathrm{g}$ per immunization.

denatured receptor and residing in the interstitial fluid binds to the cytoplasmic side of AChR during the extraction procedure: the binding of anti-RCM-AChR to muscle $A C h R$ is therefore an in vitro artefact. Finally, but less likely, the receptor loss in EAMG is mediated by immune cells and not antibody. In order to refute or confirm the hypotheses outline above an additional series of experiments was performed.

\subsubsection{RCM-AChR does not protect against EAMG}

Ten female LEW rats were immunized with $15 \mu \mathrm{g}$ of RCM-AChR in complete Freund's adjuvant; after 30 days 5 rats received a booster injection of $15 \mu \mathrm{g}$ of RCM-AChR (group I) and the other 5 rats received a booster of $15 \mu \mathrm{g}$ of native AChR (group II). Animals were bled every week from the tail vein and the antibody titer to native Torpedo AChR was measured and found to be identical in both groups of rats (fig. 7). At the time of sacrifice the animals in group I had no receptor loss in contrast to the animals in group II (table IV), who showed a receptor loss of about $25 \%$. Both groups had comparable amounts of crossreactive antibody bound at the neuromuscular junction.

These results show that prior immunization with $\mathrm{RCM}-\mathrm{AChR}$ does not protect against EAMG induced with native Torpedo AChR. Also immunization with RCM-AChR does not in our hands protect against an ongoing EAMG as claimed by others using rabbits (18) $(66 \pm 7,5 \%$ AChR loss in aminals with ongoing EAMG injected with 15 $\mu \mathrm{g}$ RCM-AChR in CFA versus $67 \pm 5,8 \%$ AChR loss for control animals injected with $15 \mu \mathrm{g}$ native $\mathrm{AChR}$ in CFA.) 


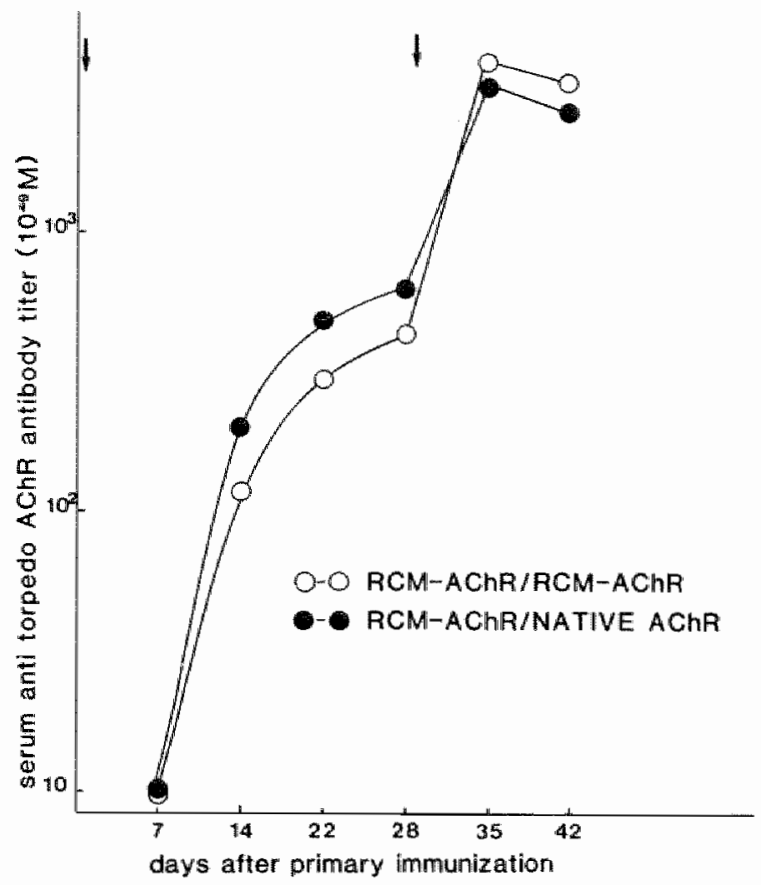

Fig. 7: Time course of anti-Torpedo AChR antibody titers in rats immunized with their RCMAChR (open circles) or with RCM-AChR and native AChR (closed circles). The booster injection was given on day 28 .

Table IV RCM-AChR does not protect against EAMG

\begin{tabular}{|c|c|c|c|c|}
\hline \multirow[t]{2}{*}{ Group } & \multicolumn{2}{|c|}{ Immunogen (AChR) } & \multirow{2}{*}{$\begin{array}{l}\text { \% AChR loss } \\
(\mathrm{m} \pm \mathrm{S} . \mathrm{E} \text {. }\end{array}$} & \multirow{2}{*}{$\begin{array}{l}\% \text { AChR complexed with ab } \\
(\mathrm{m} \pm \text { S.E. })\end{array}$} \\
\hline & 1st. & 2nd & & \\
\hline Group & $\mathrm{RCM}$ & RCM & $0 \pm 4$ & $42 \pm 3.6$ \\
\hline Group II & $\mathrm{RCM}$ & native & $25 \pm 5$ & $55 \pm 6.4$ \\
\hline
\end{tabular}

Two groups of rats were immunized with $15 \mu \mathrm{g}$ of RCM-AChR in CFA. A second injection with either RCM-AChR (group I) or native AChR (group II) was given 25 days after the initial immunization. Animals were sacrificed on day 42 .

\subsubsection{Cross-reactive antibody elicited by RCM-AChR binds to in vivo non-accessible antigenic sites on rat $\mathrm{AChR}$}

In order to relate the lack of pathogenicity of RCM-AChR to antibody specificity we analyzed if anti-RCM antibody bound to extracellular parts of $A C h R$ incorporated in native membranes or to buried determinants. 
Table V Specificities of antisera against $\mathrm{RCM}$ and native $\mathrm{AChR}$

\begin{tabular}{|c|c|c|c|c|}
\hline \multirow[t]{2}{*}{ serum } & \multirow[t]{2}{*}{ immunogen } & \multirow{2}{*}{$\begin{array}{l}\text { titer } \\
\text { (nM) }\end{array}$} & \multicolumn{2}{|c|}{$\%$ of antibody actiwity that } \\
\hline & & & binds to membranes & remains in supernatante \\
\hline 1 & RCM-AChR & 430 & 23 & 87 \\
\hline 2 & RCM-AChR & 320 & 39 & 61 \\
\hline 3 & $\mathrm{RCM}-\mathrm{AChR}$ & 320 & 29 & 71 \\
\hline 4 & $\mathrm{RCM}-\mathrm{AChR}$ & 470 & 34 & 66 \\
\hline 5 & native AChR & 99 & 88 & 12 \\
\hline 6 & native $\mathrm{ACh} R$ & 370 & 70 & 30 \\
\hline 7 & native $\mathrm{ACh} R$ & 83 & 79 & 21 \\
\hline 8 & native $\mathrm{ACh} R$ & 380 & 78 & 22 \\
\hline
\end{tabular}

) Antisera against RCM or native AChR diluted $1 / 20$ were incubated with an approximately 100 -fold excess of native Torpedo membranes (vesicles)

) The antibody activity absorbed by Torpedo membranes

9) The antibody activity not absorbed by Torpedo membranes

Serum $(20 \mu \mathrm{l})$ from rats immunized with RCM-AChR $(15 \mu \mathrm{g})$ or native AChR was diluted $(1 / 20)$ in PBS-BSA-NaN3 (10 mM Na phosphate, $5 \mathrm{mg} / \mathrm{ml}$ Bovine serum albumin, $10 \mathrm{mM}$ azide) and incubated with an excess of native Torpedo membranes $(30 \mu \mathrm{mol})$ in a total volume of $100 \mu \mathrm{l}$ overnight at $4^{\circ} \mathrm{C}$. The antibody activity in the supernatant was determined by radioimmunoassay. The amount of antibody remaining in the supernatant was compared to that of a serum sample to which no membranes had been added.

It is clear from table $\mathrm{V}$ that most of the anti RCM antibody activity (69\%) does not bind to native membranes and is therefore directed to determinants buried in the membranes or to cytoplasmic surface of AChR. In contrast, the antibody activity against native $A C h R$ was absorbed by native membranes and thus directed to extracellular parts of $\mathrm{AChR}$.

These results suggest that $\mathrm{RCM}-\mathrm{ACh}$ is not pathogenic because its most immunogenic parts are located on the cytoplasmic surface of native AChR. Consequently, the majority of antibodies against RCM do not bind to $\mathrm{AChR}$ in vivo and can only bind to solubilized AChR which is freed from its surrounding membrane. The majority of antinative AChR antibodies bind to the MIR located on the extracellular part of AChR (23). Similar results were obtained by Froehner with polyclonal antisera and monoclonal antibodies against sodium dodecyl sulfate denatured receptor or its subunits (22). Only 10-20\% of the determinants recognized by these antisera are accessible to antibodies when the receptor is membrane bound (22). Most of the monoclonal antibodies to denatured AChR bound to AChR only when membranes were made permeable with saponin $(24,25)$. 


\subsubsection{Passive transfer of EAMG by monoclonal antibody}

The previous experiments show that crossreactive antibody elicited by RCM-AChR binds to the cytoplasmic side of the AChR which is in vivo inaccessible. Thus immunization with RCM-AChR does not cause receptor loss and the crossreactive antibody bound to the rat AChR must be regarded as in vitro phenomenon or - in terms of pathogenesis of disease - as an "artefact". In order to substantiate this view monoclonal antibodies directed against RCM-AChR (no. 157, 158, 164) and against the MIR (no. 35) were infused into LEW rats; 48 hours later they were sacrificed and the receptor concentration was determined. Only rats infused with monoclonal antibody directed against the MIR (table VI, rats 10, 11, 12 group D) had AChR loss from muscle. No significant amounts of $\mathrm{ab}$ - above background IgG - were found complexed to the receptor regardless of the monoclonal antibody used. This is probably due to the fact that relatively small quantities of antibody $(40 \mu \mathrm{mol})$ were infused, compared to total AChR receptor present in rat muscle (about $70 \mu \mathrm{mol}$ )

These results are consistent with the findings of Froehner and Sargent that antibodies to denatured AChR, and as we have shown RCM-AChR, bind to cytoplasmic domains of $\operatorname{AChR}(21,22)$. These results explain why RCM-AChR does not induces EAMG.

Table VI Passive transfer of EAMG with monoclonal antibody against AChR

\begin{tabular}{|c|c|c|c|c|c|}
\hline Group & MAB & specificity & $\begin{array}{l}\text { amount inj. } \\
\text { (pmoles anti } \\
\text { rat } A C h R \text { ab) }\end{array}$ & $\begin{array}{l}\text { animal } \\
\text { no. }\end{array}$ & $\begin{array}{l}\text { (AChR) } \\
\text { fmol/g } \\
\text { muscle }\end{array}$ \\
\hline$\overline{\mathrm{A}}$ & 157 & RCM-AChR & 100 & $\begin{array}{l}1 \\
2 \\
3\end{array}$ & $\begin{array}{l}0.46 \\
0.48 \\
0.45\end{array}$ \\
\hline B & 158 & RCM-AChR & 150 & $\begin{array}{l}4 \\
5 \\
6\end{array}$ & $\begin{array}{l}0.41 \\
0.46 \\
0.49\end{array}$ \\
\hline $\mathrm{C}$ & 164 & RCM-AChR & 100 & $\begin{array}{l}7 \\
8 \\
9\end{array}$ & $\begin{array}{l}0.42 \\
0.55 \\
0.47\end{array}$ \\
\hline $\mathrm{D}$ & 35 & $\begin{array}{l}\text { native } A C h R \\
\text { (MIR) }\end{array}$ & 40 & $\begin{array}{l}10 \\
11 \\
12\end{array}$ & $\begin{array}{l}0.28 \\
0.25 \\
0.30\end{array}$ \\
\hline $\mathbf{E}$ & saline & - & - & $\begin{array}{l}13 \\
14 \\
15\end{array}$ & $\begin{array}{l}0.53 \\
0.54 \\
0.49\end{array}$ \\
\hline
\end{tabular}

Monoclonal antibodies were infused into female LEW rats. Rats were sacrificed 48 hours later and $\mathrm{AChR}$ was quantitated. 


\subsection{PASSIVE TRANSFER OF EAMG WITH IMMUNE LYMPHOCYTES}

Although EAMG can be passively transferred by polyclonal (26) as well as monoclonal antibody $(18,27,28)$ a role of immune lymphocytes in terms of effector cells (e.g. cytotoxic $T$ or delayed type hypersensitivity cells) in this model of chronic EAMG has not been ruled out. Attempts by Lennon et al. to transfer rat EAMG passively with $6 \times 10^{8}$ cells were only partially succesful and no antibody to muscle AChR could be detected (20) suggesting that antibody was required for producing EAMG. These findings of Lennon et al. in EAMG can be put in juxtaposition with those of Panitch who transferred experimental autoimmune encephalomyelitis to LEW rats with small numbers $\left(2 \times 10^{6}\right)$ of in vitro cultured immune lymphocytes provided these cells were cultured in presence of myelin basic protein or in the presence of a $T$ lymphocyte mitogen: concanavalin A.(30) Thus in the autoimmune encephalomyelitis model, which is known to be mediated by immune $T$ lymphocytes (31), passive transfer with immune lymphocytes is possible and cloned $T$ cell lines, which are also effective in this regard (32) are only needed for determining fine specificities.

Using the approach of Panitch et al. we reexamined the issue of cellular immunity in EAMG by means of passive transfer with in vitro cultured immune lymphocytes using AChR, or $\mathrm{T}$ cell mitogens (concanavalin $\mathrm{A}$ ) or $\mathrm{B}$ cell mitogens (lipopolysaccharide (LPS) and dextran sulfate (DS) to expand the in vitro cultured immune lymphocytes. Immune cells were isolated from the lymph nodes of rats with chronic EAMG induced by immunizing LEW rats with $15 \mu \mathrm{g}$ of Torpedo and cultured under conditions as described for the in vitro proliferation assays (Chapter III, pg.54) as follows. Immune lymph node cells $\left(20 \times 10^{6}\right)$ were cultured in $10 \mathrm{ml}$ medium (5\% FCS/RPMI/1640) supplemented with penicillin, streptomycine, and $5 \times 10^{-5} \mathrm{M}$ mercapto-ethanol. Torpedo $A C h \mathbb{R}$ was added at a concentration of $0.5 \mu \mathrm{g} / \mathrm{ml}$, a concentration previously found to be optimal for in vitro stimulation (Chapter III, p. 54). Alternatively concanavalin A $(2 \mu \mathrm{g} / \mathrm{ml})$, or LPS/dextransulf fate ( 50 and $25 \mu \mathrm{g} / \mathrm{ml}$ respectively) were added instead of $\mathrm{AChR}$. Cells were next cultured for 3 days (ConA or LPS/dextran) or 5 days (AChR) at $37{ }^{\circ} \mathrm{C}$ in $5 \% \mathrm{CO}_{2}$ and $95 \%$ air, harvested, washed in medium to remove mitogens or $\mathrm{AChR}$, and next transferred passively into 10 to 12 week old rats. The recovery of cells thus cultured varied from 50 to $60 \%$. The sera of the recipient rats were assayed for anti $\mathrm{AChR}$ antibody.

\section{Results and comments.}

Immune lymph node cells were expanded in vitro with Torpedo AChR, or , $T$ cell mitogen (concanavalin A) or B cell mitogen (LPS/dextran sulfate) and next varying numbers of expanded cells were passively transferred to groups of two to three female LEW rats. The antibody response of the recipients was monitored over a 50 day period and rat muscle $A C h R$ was quantitated at 52 days after passive transfer. Clinical myasthenia was not observed in this passive transfer system regardless of the way the immune cells were expanded. Only in the presence of AChR (table VII) in the in vitro 
Table VII Passive transfer of EAMG with in vitro expanded immune lymph node cells

\begin{tabular}{|c|c|c|c|c|c|c|}
\hline \multirow{2}{*}{$\begin{array}{l}\text { no. } \\
\text { cells }\end{array}$} & \multirow{2}{*}{$\begin{array}{l}\text { no, } \\
\text { anim. }\end{array}$} & \multicolumn{3}{|c|}{ in vitro expansion } & \multirow{2}{*}{$\begin{array}{l}\text { antibody titer } \\
\text { (nM/l) } \\
\text { at } 7 \text { days }\end{array}$} & \multirow[t]{2}{*}{$\%$ AChR loss } \\
\hline & & $\overline{\mathrm{AChR}}$ & $\operatorname{Con} A$ & LPS/DS & & \\
\hline $10 \times 10^{6}$ & 2 & & & + & 20 & $\overline{N D}$ \\
\hline $20 \times 10^{6}$ & 2 & & & + & 54 & ND \\
\hline $40 \times 10^{6}$ & 2 & & & + & 61 & ND \\
\hline $10 \times 10^{6}$ & 3 & & + & & $<0.5$ & 0 \\
\hline $1 \times 10^{6}$ & 3 & + & & & 41 & ND \\
\hline $10 \times 10^{6}$ & 2 & + & & & 400 & 1,22 \\
\hline $20 \times 10^{6}$ & 2 & + & & & 560 & 28,31 \\
\hline $40 \times 10^{8}$ & 2 & + & & & 560 & 38,28 \\
\hline
\end{tabular}

Immune lymph node cells were taken from rats immunized with $15 \mu \mathrm{g}$ of Torpedo californica AChR and cultured in vitro for 5 days with Torpedo AChR $(0.5 \mu \mathrm{g} / \mathrm{ml}$ ) or T cell mitogen (Concanavalin A) or B cell mitogens (LPS/DS) for 3 days prior to passive transfer. In the recipients antibody to Torpedo AChR was assayed after 7 days. None of the recipients developed myasthenia gravis clinically over a period of 52 days. Controls included passive transfer of $60 \times 10^{8}$ immune lymph node cells not expanded and passive transfer of $40 \times 10^{6} \mathrm{immune}$ lymph node cells expanded with AChR but sonicated prior to transfer. Neither of these procedures yielded measurable quantities of antibody on the recipients.

cultures significant quantities of anti-AChR antibodies were produced provided sufficient numbers of cells $\left(10 \times 10^{6}\right.$ or more) were transferred. These antibody titers declined linearily after passive transfer (fig. 8). At 52 days significant receptor losses were observed in the animals that had produced antibody. The controls exluded that the results observed were due to passive transfer of $A C h R$ or antibody.

These results show that EAMG can be passively transferred provided the immune lymph node cells are expanded in vitro with antigen (AChR). It is also clear that in absence of the immunogen the passively transferred response "burns out" in the (virgin) recipients: thus in the model of chronic EAMG the self AChR is not capable of expanding immune $T$ helper (and thus primed $B$ ) cells. The results do not suggest that - like in experimental allergic encephalomyelitis - delayed type hypersensitivity cells or cytotoxic effector $T$ cells play a role.

\subsection{DISCUSSION}

The series of experiments described in this chapter provides new evidence in favour of antibody in the pathogenesis of chronic EAMG. First, a relationship was shown between the severity of the receptor loss and the (intravascular) concentration of antibody directed to the rat AChR. This relationship is a "rough" one since the intravascular 


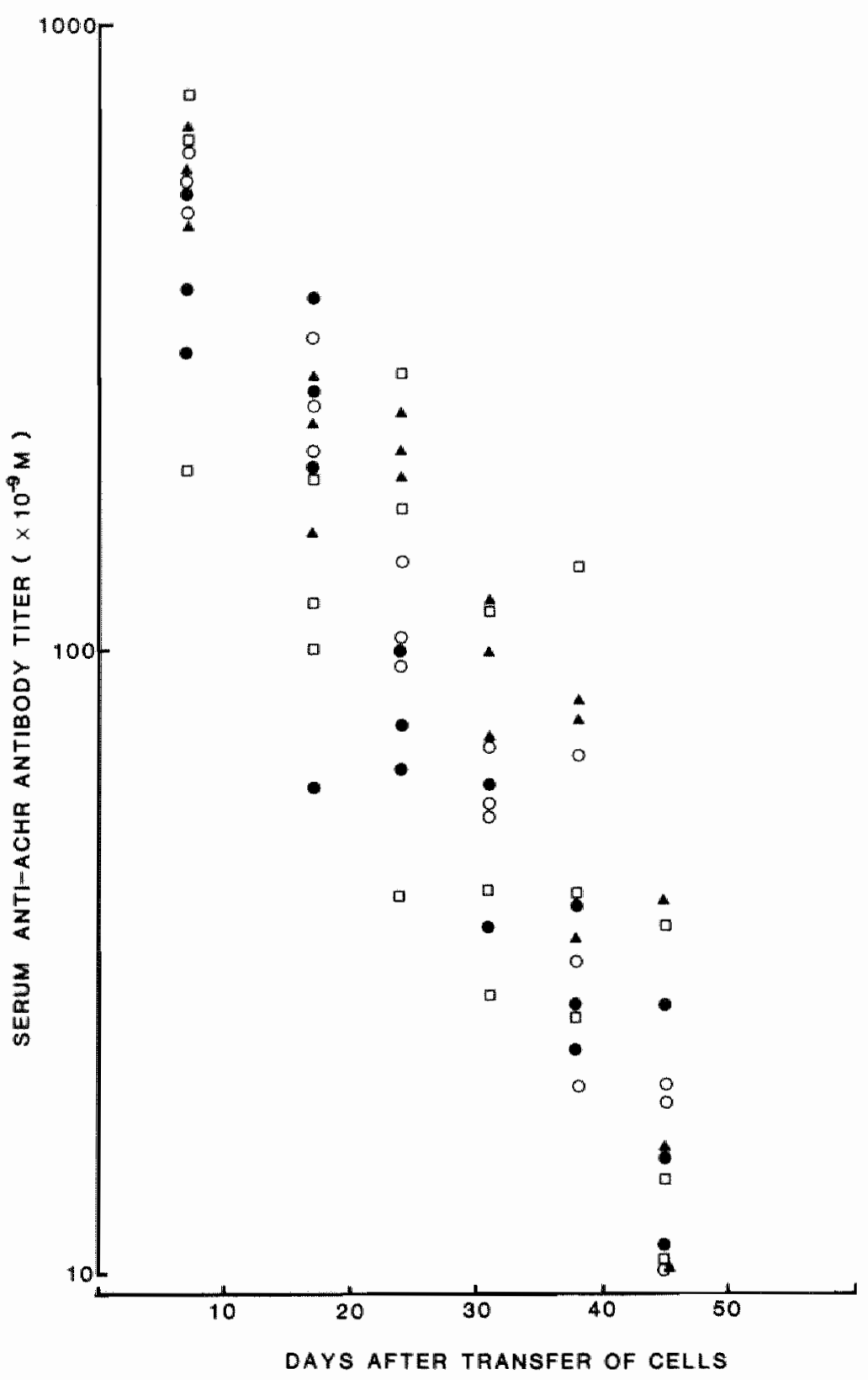

Fig. 8: Time course of anti-Torpedo AChR antibodies in rats receiving in vitro expanded immune lymphocytes from animals with EAMG. Normal Lewis rats were injected i.p. with $10 \times 10^{6}(\bullet)$, $20 \times 10^{6}(0), 40 \times 10^{6}(\mathbf{A})$, or $60 \times 10^{6}(\square)$ immune lymphocytes cultured for 5 days in the presence of AChR. Anti-Torpedo AChR antibody concentration was measured at the inclicated time points. 
immunoglobulin concentration differs from the interstitial one (15), but more importantly because we have shown that native Torpedo $\mathrm{AChR}$ elicits antibody which binds both to the extracellular and cytoplasmic sites of the AChR (section 4.4.5.). Onlly the antibodies binding to the extracellular sites, however, can be considered to be of pathogenetic significance for two reasons.

Immunization with Torpedo AChR stripped of the main immunogenic region (MIR) by reduction and carboxymethylation ( $R C M-A C h R$ ) elicited antibodies which bound to rat AChR in vitro but failed to cause receptor loss in vivo, because all antibody bound to the cytoplasmic in vivo non accessible site of the AChR. This was confirmed by passive transfer studies with monoclonal antibodies directed against native and RCM-AChR, which showedl receptor loss only with monoclonal antibody directed to the extracellularly located MIR but not with monoclonal antibody directed against RCM-AChR (section 4.4.5.). These results agree in part with the findings of Bartfeld and Fuchs (21) on the failure to elicit EAMG in rabbits injected with RCM-AChR. They do not substantiate the other observations of Bartfeld and Fuchs et al. (21), who showed a protective effect in only two rabbits of immunization with RCM-AChR on the development of EAMG (21). Our results do agree with work of others who hold antibodies to the MIR to be of particular pathogenetic importance in EAMG $(18,23)$. In our view the failure of RCM-AChR to protect against EAMG can best be explained by a carrier effect. This view holds native AChR to contain a "carrier protein" and a "MIR" hapten. Since RCM-AChR contains only the carrier, preimmunization cannot be expected to prevent an immune response to the hapten in the absence of induction of tolerance (to the carrier); on the contrary carrier priming enhances the immune response to a hapten (33).

The second set of arguments in favour of antibody mediating chronic EAMG derives from passive transfer studies with immune lymph node cells. Using techniques identical to others in studying experimental allergic encephalitis (30) we failed to transfer EAMG with concanavalin A expanded immune lymph node cells. Provided immune lymph node cells were expanded in vitro with $\mathrm{AChR}$, however, disease could be transferred with immune lymph node cells. Since antibody was produced in the recipients, these passive transfer studies favour $\mathrm{T}$ helper cells - together with primed $\mathrm{B}$ cells mediating the effects. This is in agreement with our in vitro work (chapter III). This evidence is preeliminary, however, since the expanded immune lymphe node cells were not dissected into various $T$ cell subsets and $B$ cells prior to passive transfer.

Wekerle et al. using cell lines derived from lymphocytes of rats with EAMG, have shown that their lines express the $T$ helper cell phenotypes. These cells were effective in inducing EAMG when injected along with primed B cells and AChR in CFA (34). In our lymphocyte transfer we did not need to inject $A C h R$ in CFA to induce disease. This can best be explained by the fact that our in vitro activated lymphocytes crossreact with the rat $\mathrm{AChR}$, whereas the cell lines of Wekerle et al. only react with Torpedo $\mathrm{AChR}$ (personal communication). Interestingly the antibody titers produced by in vitro expanded, passively transferred, immune lymph node cells in virgin recipients decreas- 
ed gradually after transfer. These data suggest that the autologous AChR does not expand these primed cells in vivo. This observation agrees with our hypothesis (Chapter III, pag.78) that probably no tolerance exists to membrane antigens that do not circulate in the extracellular fluid. This implies that the passively transferred immune lymphocytes are not expanded by circulating antigen. Apparently mammalian (c.q. rat) AChR is recognized as "foreign" which results in a vigorous immune response with a high percentage (section 4.2.1.) of antibodies crossreacting with Torpedo AChR suggesting that the immune response is directed to a group of restricted highly conservative determinants to which no tolerance exists; the region has been defined as the main immunogenic region on Torpedo and mammalian AChR (18).

The experiments in this chapter support the three stage model of pathogenesis of myasthenia gravis of Wekerle (34). This author proposed that the primary event in the development of MG is the appearance of myogenic cells expressing AChR on their cell membrane in the thymus. In a second step, intrathymically developing $T$ cells are sensitized against AChR after appropriate presentation by antigen presenting cells. Then these cells migrate to peripheral lymphoid organs where they cooperate with $\mathrm{AChR}$ specific B cells to induce autoantibody synthesis (some of these autoantibodies can also be synthesized within the thymus). The immunopathological lesions observed at the neuromuscular membrane are brought about by these autoantibodies against AChR.

\subsection{SUMMARY AND CONCLUSIONS}

In this chapter the immunogenicity of differing $A C h R$ preparations were related to their in vivo pathogenicity. For these purpose three protocols were used, each allowing the analysis of differing pathogenetic mechanisms.

\section{EAMG induced by active immunization with $A C h R$ in CFA.}

We first established the kinetics of the experimental in vivo model. The immunizing dose of native Torpedo AChR was proportional to the amount of circulating antibodies against both Torpedo and self $\mathrm{AChR}$ (rat), and the amount of antibody bound at the site of the neuromuscular junction. Removal of the MIR (RCM-AChR) did slightly reduced the immunogenicity but abolished pathogenicity. In animals immunized with RCM-AChR, lacking the MIR, most of the serum antibodies were shown to be directed to cytoplasmic, in vivo non accessible sites of muscle $\mathrm{AChR}$. In contrast to suggestions in the literature preimmunization of rats with RCM-AChR failed to protect against EAMG induced by immunization with native $A C h R$ nor was an ongoing EAMG cured by immunizations with RCM-AChR.

\section{Induction of EAMG by passive transfer with monoclonal antibodies.}

The data obtained by active immunizations with RCM-AChR were extended using monoclonal antibodies against native and RCM-AChR. Only antibodies directed to the 
extra-cellularly located MIR (present on native AChR but absent on RCM-AChR) were capable of causing AChR loss from muscle.

\section{Induction of EAMG by passive transfer of immune lymphocyte.}

In order to demonstrate that this crossreactive immune response was mediated by antibody only passive transfer studies were performed using in vitro expanded immune cells isolated from lymph nodes of animals with EAMG. I $n$ vitro expansion of immune $T$ cells with $T$ cell mitogen (in a manner identical to that used for passive transfer of effector $\mathbb{T}$ cells in experimental allergic encephalitis) failed to induce an antibody response to $A C h R$ in the recipient. Passive transfer was only successfull when the immune cells were expanded in witro in the presence of $\mathrm{AChR}$; the receptor loss observed was mediated by actively secreted and crossreactive antibody. The autoantibody levels in the serum of the recipients of passively transferred cells decreased rapidly suggesting that the autologous $A C h R$ is not capable of expanding these primed $T$ (helper) cells possibly because the membrane antigens residing on the receptor do not circulate in the extra cellular fluid.

The studies described in this chapter therefore support the view that chronic EAMG is an antibody mediated disease requiring the continuous presence of immunogen and primed helper $\mathrm{T}$ cells.

\section{References}

1. Bartfeld D and Fuchs S. Immunological characterization of an irreversably denatured acetylcholine receptor. FEBS lett. $77: 214-218,1977$.

2. Lindstrom JM. Autoimmune response to acetylcholine receptors in myasthenia gravis and its animal model. Adv. Immunol. 27: 1-50, 1979.

3. Haynes BF and Eisenbarth GS. Monoclonal antibodies: Probes for the study of attoimmunity and im munodeficiency. Academic Press, Orlandlo, 1983.

4. Fathman $\mathrm{CG}$ and Frelinger J. T-lymphocyte clones. Ann. Rev. Immunol. 1: 633-656, 1983.

5. Kees $V$ and Krammer PH. Most influenza A virus-specific memory cytotoxic $T$ lymphocyte react with antigenic epitopes associated with internal virus determinants. J. Exp. Med. 159: 365-377, 1984.

6. Heinemann. S, Merlie J and Lindstrom JM. Modulation of acetylcholine receptor in rat diaphragm by antireceptor sera. Nature (London) 274: 65-67, 1978.

7. Heinemann S, Bevan S, Kullberg R, Lindstrom JM and Rice J. Modulation of acetylcholine receptor by antibody against the receptor. Proc. Natl. Acad. Sci. USA 74: 3090-3094, 1977.

8. Sahashi K, Engel AG, Lindstrom JM, Lambert EH and Lennon VA. Ultrastructural localization of immune complexes (IgG and $\mathrm{C} 3$ )at the endplate in experimental autoimmune myasthenia gravis. $J$. Neuropathol. Exp. Neurol. 37: 212-223, 1978.

9. Engel AG, Sakakibara H, Sahashi K, Lindstrom JM, Lambert EH, Lennon VA. Passively transferred experimental autoimmune myasthenia gravis. Sequential and quantitative study of the motor end-plate: fine structure and ultrastructural localization of immune complexes (IgG and C3), and of the acetylcholine receptor. Neurology (Minneap) 29: 179-188, 1979.

10. Lennon VA, Seybold ME, Lindstrom JM, Cochrane $C$ and Ulevitch $R$. Role of complement in the pathogenesis of experimental autoimmune myasthenia gravis. J. Exp.Med. 147: 973-983, 1978.

11. Lindstrom JM, Lennon VA, Seybold ME and Whitingham S. Experimental autoimmune myasthenia gravis and myasthenia gravis: Biochemical and immunochemical aspects. Arn. NY Acad. Sci. 274: $254-274,1976$. 
12. Lennon VA, Lindstrom JM and Seybold ME. Experimental autoinmune myasthenia: A model of myasthenia gravis in rats and guinea pigs. II. Exp. Med. 141: 1365-1375, 1975.

13. Lindstrom JM, Cooper I and Tzartos S. Acetylcholine receptors from Torpedo and Electrophorus have similar subunit siructures. Biochemistry 19:1454-1458, 1980.

14. Diana JN and Fleming PB. Some current problems in microvascular research. Microvase. Res. 18: 144-152, 1979.

15. Brace RA, Taylor AE and Guyton AC. Time course of lymphoprotein concentration in the dog. Microvasc. Res. 14: 243-249, 1977.

16. Haljama $\mathbb{H}$. Anatomy of the interstitial tissue. Lymphology I1: 128-132, 1978.

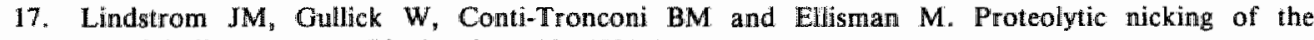
acetylcholine receptor. Biochemistry 19: 4791-4795, 1980.

18. Tzartos $\mathrm{SJ}$ and Lindstrom $\mathrm{JM}$. Monoclonal antibodies used to probe acetylcholine receptor structure: Localization of the main immunogenic region and detection of similarities between subunits. Proc. Natl. Acad. Sci. 77: 755-759, 1980.

19. Tzartos SJ, Seybold ME and Lindstrom JM. Specificities of antibodies to acetylcholine receptor in sera from myasthenia gravis patients measured by monoclonal antibodies. Proc. Natl. Acad.Sci. 79; $188-192,1982$.

20. Conti-Tronconi $B$, Tzartos $S$ and Lindstrom JM. Monoclonal antibodies as probes of acetylcholine receptor. I1. Binding to native receptor. Biochemistry $20: 2181-2191,1981$.

21. Bartfeld D and Fuchs S. Specific immunosuppression of experimental autoimmune myasthenia gravis by denatured acetylcholine receptor. Proc. Natl. Acad. Sci. USA 75: 4006-4010, 1978.

22. Froehner SC. Identification of exposed and buried determinants of the membrane-bound acetylcholine receptor from Torpedo californica. Biochemistry 20: 4905-4915, 1981.

23. Lindstrom IM, Tzartos S and Gullick W. Structure and function of the acetylcholine receptor molecule studied using monoclonal antibodies. Ann. NY Acad.Sci. 377: 1-19, 1981.

24. Froehner S, Douwille K, Klink S and Culp WJ. Monoclonal antibodies to cytoplasmic domains of the acetylcholine receptor. J. Biol. Chem. 258: 7112-7120, 1983.

25. Sargent $P B$, Hedges $B E$, Tsavaler $\mathbb{L}$, Clemmons $L$, Tzartos $S$ and Lindstrom JM. Structure and transmembrame nature of acetylcholine receptor in amphibian skeletal muscle as revealed by crossreacting monoclonal antibodies. J. Cell Biology 98: 609-618, 1984.

26. Lindstrom JM, Engel AG, Seybold ME, Lennon VA and Lambert EH. Pathological mechanisms in experimental autoimmune myasthenia gravis. II. Passive transfer of experimental autoimmune myasthenia gravis in rats with anti-acetylcholine receptor antibodies. J. Exp. Med. 144: 739-753, 1976.

27. Lennon VA and Lambert EH. Myasthenia gravis induced by monoclonal antibodies to acetyleholine receptor. Nature 285: 238-240, 1980 .

28. Richman DP, Gomez CM, Berman PW, Burres SA, Fitch FW and Arnason BGW. Monoclonal antiacetylcholine receptor antibodies can cause experimental myasthenia. Nature 286: 738-739, 1980.

29. Lennon VA, Lindstrom JM and Seybold ME. Experimental autoimmune myasthenia gravis: cellular and humoral immune response. Anm. NY Acad. Sci. 274: 283-299, 1976.

30. Panitch HS, McFarlin DE. Experimental allergic encephalomyelitis: Enhancement of cell-mediated transfer by concanavalin A. J. Immunol. 119: 1134-1137, 1977.

31. Ortiz Ortiz L and Weigle WO. Cellular events in the induction of experimental allergic encephalomyelitisis in rats. J. Exp. Med. 144: 604-616, 1976.

32. Ben Nun A, Cohen IR. Experimental autoimmune encephalomyelitis (EAE) mediated by $T$ cell lines; process of selection of lines and characterization of the cells. J. Immunol 129: 303-308, 1982.

33. Ovary $Z$ and Benacerraf $B$. Immunological specificities of secundary response with dinitrophenylated proteins. Proc.Soc.Exp. Bül.Med. 114: 72-76, 1963.

34. Wekerle H, Hohlfeld R, Ketelsen VP, Kalden JR and Kalies I. Thymic myogenesis, T-lymphocytes and the pathogenesis of myasthenia gravis. Ann. NY Acad. Sci. 377: 455-476, 1981. 


\section{CHAPTER V}

\section{Anti-AChR antibody - Acethylcholine receptor interactions: Analysis of mechanisms that influence the severity of myasthenia}

\subsection{INTRODUCTION}

Myasthenia gravis (MG) and its experimental animal model are autoimmune diseases caused by antibodies to $\mathrm{AChR}$ in muscle that impair neuromuscular transmission resulting in muscular weakness and fatigue (1). In both MG and EAMG the primary factors impairing neuromuscular transmission is antibody-induced loss of AChR. AChR loss occurs by both antigenic modulation (2-4) and complement mediated focal lysis of the neuromuscular endplate (5-7). Conceptually the anti-AChR antibody AChR interactions in chronic EAMG are influenced by antibody specificity and concentration, and target cell characteristics including the density of antigenic epitopes on the receptor as well as the capacity of the cell to regenerate $\mathrm{AChR}$.

It was shown in chapter IV that the endplate in chronic EAMG contains AChR not complexed with antibody, in spite of conditions of marked antibody excess to rat AChR suggesting that antibody specificities and target organ characteristics must be important for the development of myasthenia. The problem of antibody specificity in EAMG has been approached by blocking assays using libraries of monoclonal antibodies $(8,9)$, by passive transfer of monoclonal antibodies $(8,10,11)$ or by means of immunizing with altered AChR (chapter IV) (12). All of these indirect approaches suggest that in acute and chronic EAMG as well as myasthenia gravis antibodies directed to a small area on the extracellular surface of the $\alpha$-subunit, the so called main immunogenic region (MIR) are important in the pathogenesis of disease. These approaches have not ruled out however that low concentrations of antibodies directed to other antigenic epitopes on the extracellular surface of AChR outside of the MIR might not contribute to disease; e.g. the question whether or not antibodies directed to the acethylcholine bindling site -which is located outside of the MIR on the $\alpha$-subunit- exist remains a topic of debate $(1,13)$. For this reason we have approached the problem of antibody specificity in two ways.

First in a direct approach we assayed sera from animals with chronic EAMG for the presence or absence of antibodies directed to the acetylcholine binding site on the receptor since antibodies with such a specificity would be of crucial importance in terms of pathogenesis of disease.

Secondly, we approached the problem of antibody specificity indirectly by looking at antibody diversity in the sera of rats with chronic "EAMG by first separating immunoglobulins on the basis of charge and next by determining antigen binding capacity of these separated immunoglobulins. By wirtue of this manoeuvre low concentrations 
of antibodies secreted by a small number of B cell clones possibly of importance for the pathogenesis of EAMG, might be detected theoretically (15). For clarity the literature dealing with the approaches alluded to above is cited separately under the appropriate heading in the result section.

\subsection{ROLE OF ANTIBODY TO THE ACETYLCHOLINE BINDING SITE IN CHRONIC EAMG}

EAMG can be induced by immunization with native AChR or with any of the four subunits composing $\mathrm{AChR}$, and in animals immunized with intact $\mathrm{ACh}$ antibodies are produced to all subunits (16). However, studies employing monoclonal antibodies (MABs) have shown that, although rats with EAMG make antibodies to many parts of the AChR moleculle, most are directed at a small part of the extracellular surface of the $\alpha$-subunit, referred to as the "main immunogenic region" $(8,9)$. The acetylcholine binding sites are also located on the $\alpha$-subunit, but are not part of the main immunogenic region $(8,9,10)$. The use of MABs with known specificities as competitive inhibitors of the binding of autoantibodies from MG patients to human AChR showed that these patients have a similar pattern of anti AChR specificities as rats with EAMG, and that most antibodies from MG patients are also directed to the main immunogenic region $(8,9)$. Antibodies of this specificity are thought to be pathogenetically important because MABs can passively transfer the complement-dependent, acute form of EAMG $(8,18,19)$ as well as crosslink $\mathrm{AChR}$ and induce antigenic modulation of $\operatorname{AChR}(18,20)$. It seems likely that these antibodies cause AChR loss by fixing complement or by crosslinking AChRs to induce AChR modulation, antibodies that directly impair AChR function competitively or noncompetitively are rarely identified (18). Recent reports however suggest that inhibition of $A C h R$ activity may be important in situations where the number of $A C h R$ is already reduced (12). Differing results have been reported in testing the ability of anti $A C h R$ antisera to inhibit $\alpha$-bungarotoxin or acetylcholine binding to $\operatorname{AChR}(1,13,14)$. All these studies used immunoprecipitation techniques. In this type of assay two phenomena are analysed simultaneously: binding of antibodies to AChR and immunoprecipitation of AChR-antibody complexes. Several factors that interfere with the immunoprecipitation reaction could give false positive results for the existence of anti-acetylcholine binding site antibody. In order to answer this question we developed a solid phase assay where AChR with or without blocked acetylcholine binding site, is attached to plastic (microtiter plates) and subsequently incubated with anti-AChR antibodies in serial dilutions from animals with chronic EAMG. The binding of these antibodies was revealed by means of an enzym labeled second antibody (see material and methods section, p.157).

\section{Results and comments.}

When $1 \times 10^{-12} \mathrm{~mol}$ (in bicarbonate buffer $0.01 \mathrm{M}, \mathrm{pH} 9.6$ ) AChR was incubated in microtiter wells, $44 \times 10^{-15} \mathrm{~mol}$ (4.4\% of the amount $\mathrm{ACh}$ R added) effectively bound 


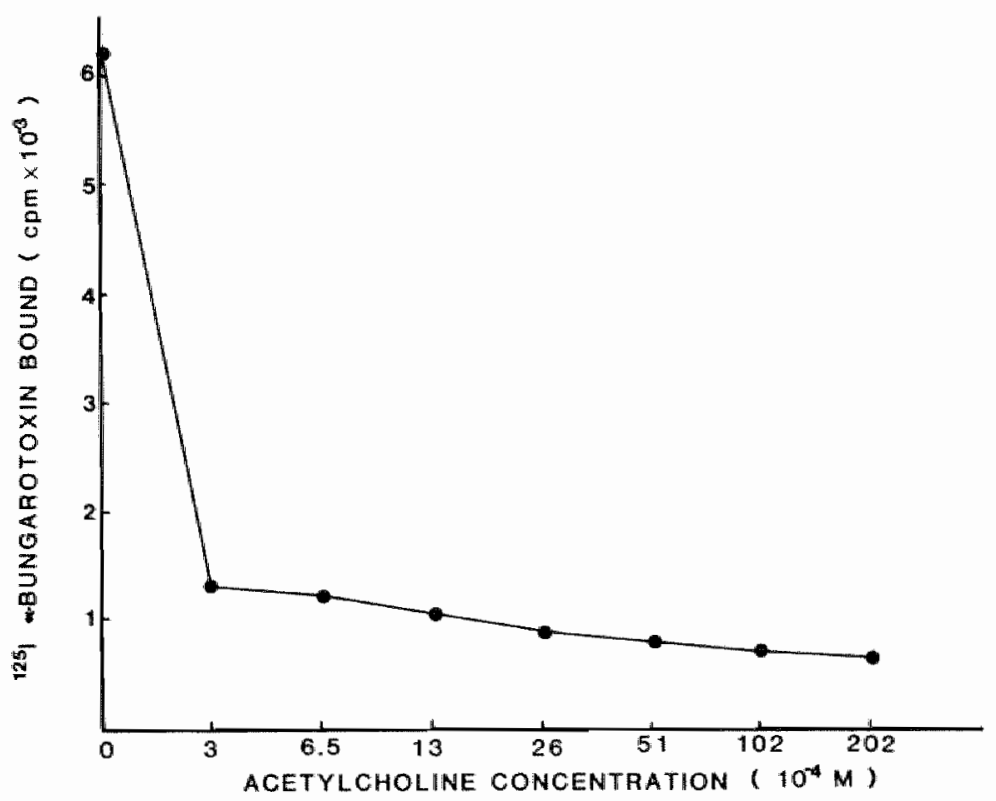

Fig. 1 Effect of acetylcholine on ${ }^{125}[-\alpha-B G T$ binding to $A C h R$ in a solid phase radioimmunoassay (for explanation see text).

to the plastic as assessed by ${ }^{125} \mathrm{I} \alpha$-bungarotoxin binding sites available for binding. We next determined the amount of acetylcholine in the fluid phase necessary to block $\alpha$ bungarotoxin binding. As seen in fig. 1 concentrations of $3.10^{-4} \mathrm{M}$ acetylcholine almost completely blocked the binding for ${ }^{125} \mathrm{I} \alpha$-bungarotoxin; the binding of ${ }^{225} \mathrm{I} \alpha$ BGT could not completely be blocked by concentrations of acetylcholine as high as 20 $\mathrm{mM}$. The failure to completely block $\alpha$-BGT binding to AChR can be explained by the high association constant of $\alpha$-BGT $\left(10^{14} \mathrm{l} / \mathrm{mol}\right)$. Antibodies however, have association constants which are several orders of magnitude lower compared to $\alpha-\mathrm{BGT}$. We therefore incubated AChR coated microtiter plates with acetylcholine (5 mM), together with the acethylcholine-esterase inhibitor neostigmine bromide (Sigma Co, St. Louis), at $5 \times 10^{-3} \mathrm{M}$ in order to prevent acethylcholine breakdown, and different sera taken from rats with chronic EAMG. The binding of the anti-AChR antisera was only marginally decreased in the presence of acetylcholine (fig 2). From these experiments it can be concluded that circulating antibodies against the acetylcholine binding site are present in sera from animals with EAMG, but that the titer of these antibodies is extremely low. It is conceivable that these antibodies against the acetylcholine binding site are capable to bind to AChR in the presence of high concentrations of antibodies against the MIR, since both the MIR and the binding site are present on the extracellular part of the $\alpha$-subunit. It is therefore possible that antibodies against the acetylcholine binding site play a minor role in determining disease severity. This view 


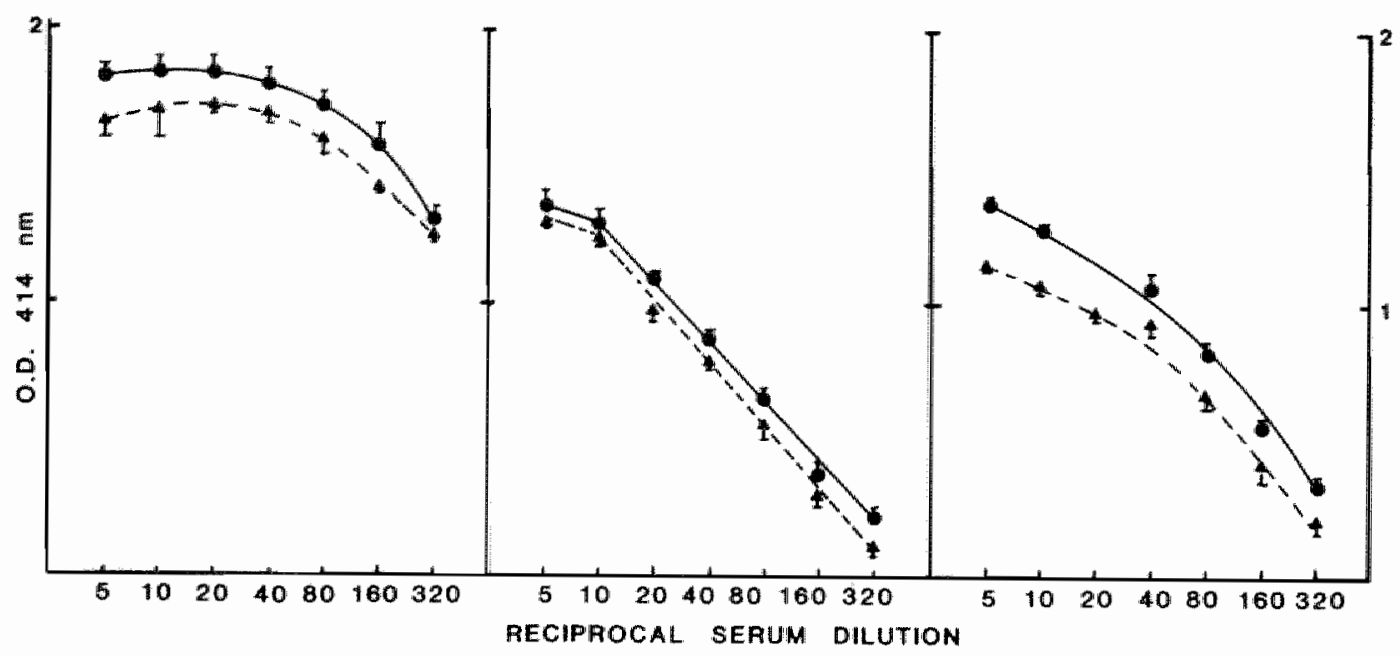

Fig. 2 Anti-acetylcholine binding site antibodies. Three sera from rats with EAMG were assayed for anti-AChR antibody by ELISA in the presence (dashed line) or absence of acetylcholine and neostigmine bromide.

receives some support from the literature where in vivo injection of monoclonal antibodies to the acetylcholine binding site produced a clinical picture differing from chronic EAMG in that these monoclonal antibodies produced an acute paralysis in chicken hatchlings (21).

\subsection{THE ROLE OF ANTIBODY DIVERSITY IN EAMG}

Isoelectric focusing (IEF) is a method frequently used to analyse the diversity of antibodies in terms of V-region variability involved in an immune response (15), but so far not applied to the study of EAMG. In isoelectric focusing, an electric current is applied across a continuous $\mathrm{pH}$ gradient, causing proteins such as immunoglobulins to run and concentrate as narrow bands at their isoelectric point (pI), the $\mathrm{pH}$ at which their net charge is zero. The resolution power of IEF is so high that even a single myeloma protein can be separated into several bands, representing sets of molecules altered post-translationally (deamination, glycosylation, e.a.)(22). Isoelectric focusing is therefore useful for distinguishing immunoglobulin species with different variable regions and different pl's. The problem with the technique is that when a serum contains too many molecular species, the isoelectric spectrum or spectrotype (i.e. series of bands appearing after a Coomassie blue staining for proteins) is to complex. These problems can be partially overcome by using an ${ }^{125} \mathrm{I}$ antigen overlay technique for revealing the spectrotype (22). 
We have used IEF to analyze the diversity of anti AChR antibodies to Torpedo and muscle AChR in the sera and bound to the endplate of rats during the course of EAMG. This is important to determine because it is possible that antibody specificities which appeared pathologically unimportant because of their low concentrations in serum might very well bind to AChR in muscle and in fact be quite important in impairing neuromuscular transmission.

In view of these considerations an isoelectric focusing technique was adapted to analyze anti-AChR antibodies. In order to validate this technique we had to demonstrate first that antibodies complexed to antigen could be separated by isoelectric focusing, and next we had to determine the sensitivity and specificity of the method to detect antibodies to Torpedo AChR. Finally the isolectric spectrum of antibodies to Torpedo and rat AChR in serum as well as at the site of the neuromuscular junction was analyzed.

\subsubsection{Separation of complexed antibodies from antigens by isolectric focusing}

To analyze spectrotypes of antibodies that may have been complexed in vivo with their respective antigens it was necessary to develop procedures for separation of antibody from antigen prior to analysis. To determine whether a reversed electrofocusing technique could accomplish this, (see material and methods section), we examined the patterns obtained with anti-BSA antibody alone or anti-BSA complexed in vitro with BSA. Crystalline BSA (Calbiochem-Behring) repurified on Sephadex G150 column was used for the formation of model BSA-anti BSA complexes in vitro. Affinity purified IgG fraction of rabbit anti-BSA antibody was incubated with BSA at equivalence or in 5-fold antigen excess. The reaction mixture, containing trace amounts of ${ }^{131} \mathrm{I}$ labeled BSA and ${ }^{125} I$ labeled rabbit anti-BSA IgG was incubated for 2 hours at room temperature and then overnight at $4^{\circ} \mathrm{C}$. After centrifugation at $1000 \mathrm{~g}$ for 10 minutes the precipitate was washed repeatedly and resuspended with IEF sample buffer.

\section{Results and comments.}

In this experiment antigen (BSA) and antibody were trace labeled with ${ }^{131} \mathrm{I}$ and ${ }^{125} \mathrm{I}$ respectively (fig. 3, lane 1-3), before assessment and electrofocused separately or as antigen antibody complexes. Unlabeled antibody complexed with unlabeled antigen was focused too and next reacted with radiolabeled antigen (fig. 3, lane 4). The resulting banding pattern was identical whether or not the antibodies had initially been complexed with antigens. Thus, the IEF pattern of autoantibodies should not be altered by any complexes between these antibodies and autoantigens which might be present. Using a reverse isoelectric focusing technique, the samples migrate through a zone of acid $\mathrm{pH}(\mathrm{pH}= \pm 3)$ and immune complexes are separated in their respective constituents. Subsequent incubation with radiolabeled antigen reveals the full spectrotype of antibodies. 


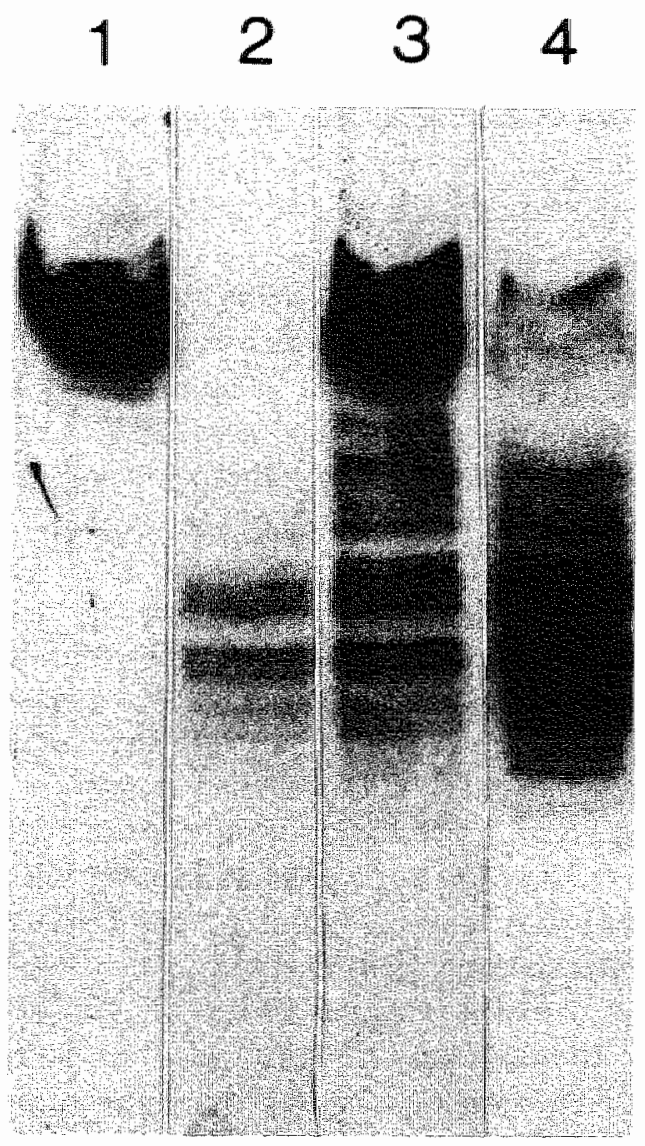

Fig. 3 Separation of constituent antigen and antibodies from immune complexes by reversed IEF. Lane 1, ${ }^{131}$ I-BSA; lane 2, ${ }^{125}$ I anti-BSA; lane 3, ${ }^{34}$ I-BSA-125I anti-BSA complexes; lane 4, unlabeled BSA-anti BSA complexes, overlayed with ${ }^{125}$ I-BSA.

\subsubsection{Sensitivity and specificity of analytical IEF of antibodies to Torpedo AChR}

The sensitivity and specificity of this IEF technqiue was determined by using monoclonal antibodies to AChR. The preparation and characterization of rat monoclonal antibodies used in this study is described in the material and method section (see addendum). Classes and subclasses of $M A B s$ to $A C h R$ were determined by radial double immunodiffusion using monospecific antisera to rat immunoglobulins kindly provided by Prof. H. Bazin (University of Louvain, Brussels, Belgium) (table II). 
Table II. Characterization of MABs used for IEF

\begin{tabular}{lllll}
\hline MAB number & Torpedo AChR & specificity & animal strain & Isotype \\
\hline 1 & Torpedo AChR & $\alpha(\mathrm{MIR})$ & Lewis & IgG2b \\
3 & Torpedo AChR & $\alpha$ & Lewis & IgG2b \\
5 & Torpedo AChR & $\alpha$ & Lewis & IgG2b \\
6 & Torpedo AChR & $\alpha(\mathrm{MIR})$ & Lewis & IgG1 \\
17 & Eel \& Torpedo AChR & $\alpha, \beta$ & Lewis & IgG2b \\
22 & Eel AChR & $\alpha$ & Lewis & IgG2b \\
35 & Eel AChR & $\alpha(\mathrm{MIR})$ & Sprague Dawley & IgGI \\
42 & Eel AChR & $\alpha(\mathrm{MIR})$ & Louvain & IgG2a
\end{tabular}

Results and comments.

Polyclonal antisera from rats immunized with Torpedo AChR, and monoclonal antibodies to Torpedo AChR were first electrofocused in the gel; next the gell was incubated with radiolabeled $A C h R,\left({ }^{125} I-\alpha\right.$-bungarotoxin-AChR), in order to image the binding sites by autoradiography.

Even a single MAB produced a pattern of at least 6 bands (fig. 4). Thus single IEF bands cannot be thought of as a sole product of a single anti-AChR clone. Note also that the pattern of bands given by MAB 6 does not resemble the pattern of bands given by a serum pool. Yet MAB 6 is directed at the main immunogenic region and can inhibit the binding of $70 \%$ of the antibodies into Torpedo AChR (8). This indicates that there is no obvious correlation between the isoelectric points at which a particular antibody binds and its binding specificity. As little as $170 \mathrm{ng}\left(1.1 \times 10^{-12} \mathrm{~mol}\right)$ of a monoclonal antibody to $A C h R$ (MAB 6) could result in a full expression of antibody spectrotype as seen following overlay with labeled antigen ( fig. 4, lane 3-6). Similar experiments with affinity purified anti-BSA showed that as little as $200 \mathrm{ng}$ could result in full spectrotype expression (not shown).

The specificity of this IEF technique is also shown in fig. 4. First, normal rat serum did not bind radiolabeled AChR (fig. 4, lane 7) and, second, immune serum preadsorbed with AChR-rich membranes failed to bind radiolabeled AChR (fig. 4, lane 2) in contrast to unabsorbed serum (fig. 4, lane 1). Absorption of the immune sera with an unrelated antigen (BSA) had no effect on the binding of AChR (not shown). MABs against $A C h R$ were used to define the sensitivity and the discriminating ability of this technique (fig. 5). We found that all of the MABs tested had a restricted appearance at neutral pIs with a limited number of bands. The presence of more than one band by our MABs should not be considered as a disproof of their monoclonality. Others (22) have reported similar findings with MABs analyzed by IEF and attributed this phenomenon to carbohydrate heterogenetity, deamination and minimal amino acid sequence variability. This microheterogeneity of MABs makes these reagents less usefull for the dissection of the clonal serum antibody response by IEF. Nevertheless, as expected the MABs pI ranges were included within the pIs of the polyclonal antibodies 

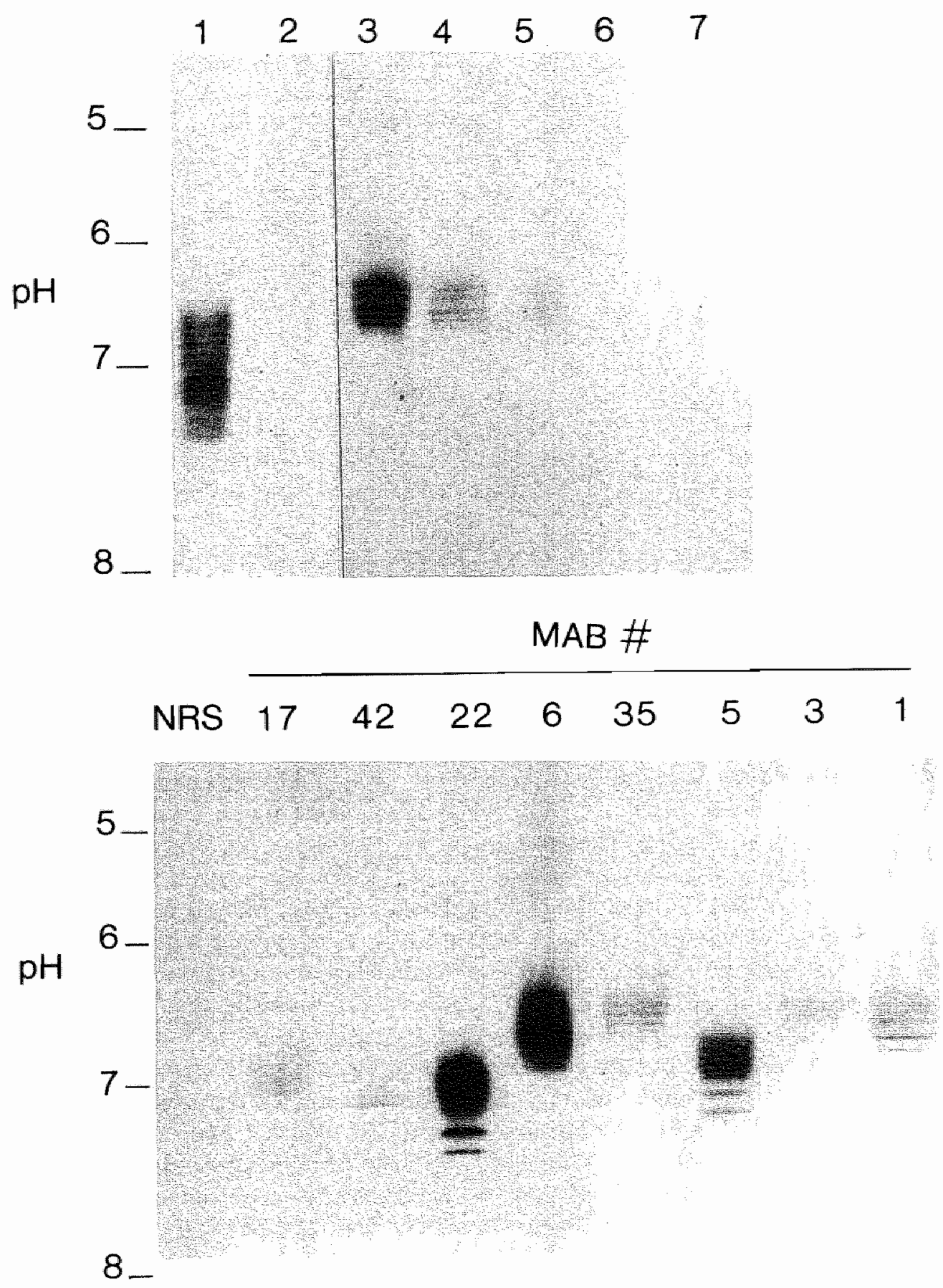

(125I) BTX-AChR 
in sera of rats with EAMG. Therefore, a panel of MABs can be taken to represent the spectrum of the serum antibody response to $A C h R$.

\subsubsection{Isoelectric spectra of antibodies to Torpedo and muscle $\mathbf{A C h R}$}

The previous experiments showed reversed isoelectric focusing with ${ }^{125}$ I labeled antigen overlay to be a specific and sensitive tool for the analysis of the anti AChR antibody spectrum. In order to determine whether early and late spectrotypes of antibodies directed to muscle and Torpedo AChR differed from each other, early and late sera were obtained from rats immunized with $15 \mu \mathrm{g}$ of Torpedo AChR in CFA. The question of cross reactivity - antibodies binding to muscle $\mathrm{AChR}$ - was raised because restriction of the spectrotypes of self antibodies would suggest the involvement of a limited number of B cell clones. We determined spectrotypes in both Brown Norway (BN) and Lewis rats since preeliminary results (Lindstrom, personal communication) suggested that like in experimental allergic encephalitis $\mathrm{BN}$ rats are rather resistant to EAMG.

\section{Results and comments.}

The isoelectric spectrum of sera derived from 4 Lewis rats with EAMG is composed of a multitude of bands observed in the range pI 6.5 to 7.5 (fig. 6). When sera from Lewis and Brown Norway rats immunized with AChR were compared, Lewis rats showed bands in the pI range 5.1 to 7.3, whereas the Brown Norway rats showed bands largely confined to the range $\mathrm{pI} 6$ to 7.5 (fig. 7); although the range of pI between LEW and $\mathrm{BN}$ rats differed, the number of bands was similar. These results do not suggest that $B N$ rats are poor responders in terms of anti $A C h R$ compared to Lewis. This was confirmed by immunizing $B N$ and LEW rats with $15 \mu \mathrm{g}$ of Torpedo $\mathrm{AChR}$ given twice 30 days apart. Both LEW and BN had comparable loss of AChR at the neuromuscular junction when measured 5 days after the booster injection (67 $\pm 7 \%$ AChR loss).

Fig. 4 Sensitivity and specificity of analytical electrofocusing of anti-AChR antibodies. Lane 1, polyclonal unabsorbed rat anti $\mathrm{AChR}$ antibodies; lane 2, polyclonal serum shown in lane 1 absorbed prior to focusing with AChR-rich membranes. Lanes 3 to 6 , containing decreasing amounts of monoclonal (MAB 6) antibody to AChR (lane 3, $550 \times 10^{-12}$ moles, lanes $4,11 \times$ $10^{-12}$ moles, lane 5, 5.5. $\times 10^{-12}$ moles and lane $6,1.1 \times 10^{-12}$ moles). Lane 7 , normal rat serum. All gels following focusing of sera or monoclonal antibodies were reacted with ${ }^{125} 1$ - $\alpha$-BGTAChR and then imaging was obtained by autoradiography.

Fig. 5 Isoelectric patterns of MABs to Torpedo AChR (no. 17, 42, 22, 6, 35, 5, 3 and 1). Lane 1: Five $\mu \mathrm{l}$ normal rat serum. lane 2-5: five $\mu \mathrm{l}$ concentrated tissue culture supernatants. Both were focused and overlayed with ${ }^{125} \mathrm{I}-\alpha$-BGT labeled Torpedo AChR. 

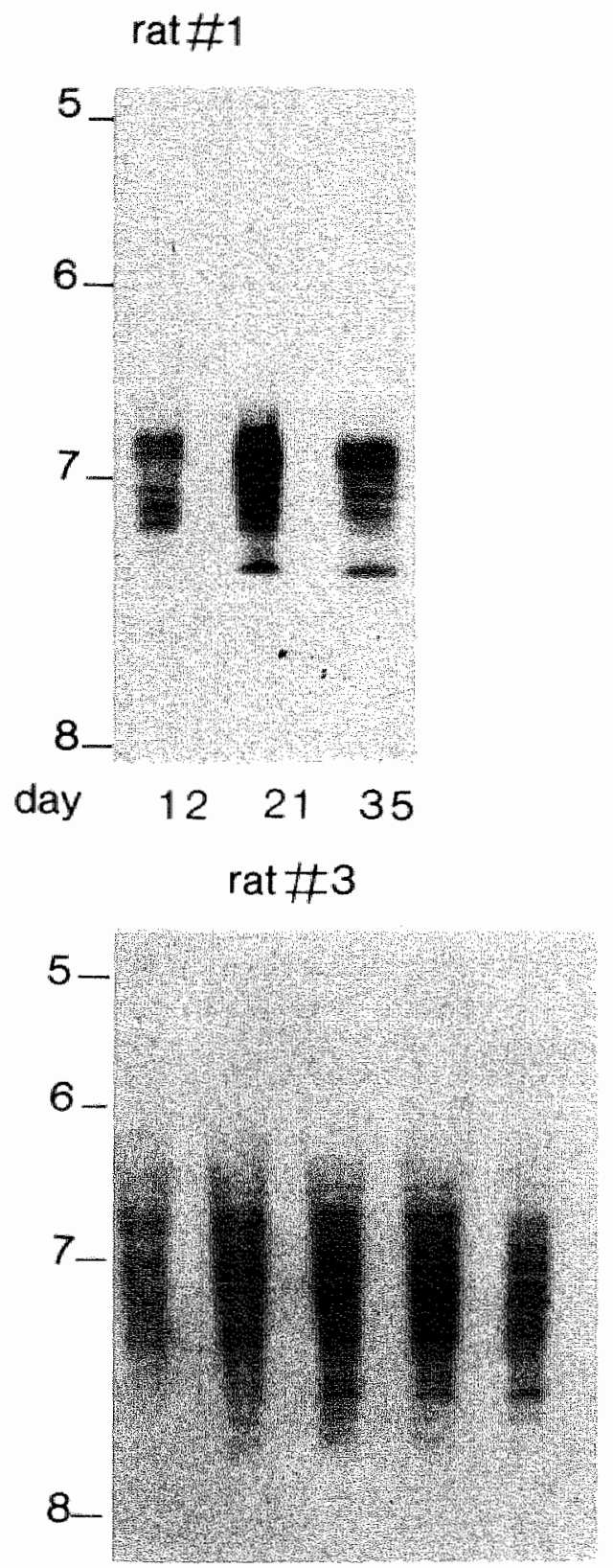

$\begin{array}{llllll}\text { day } & 10 & 14 & 17 & 21 & 30\end{array}$ rat $\# 2$

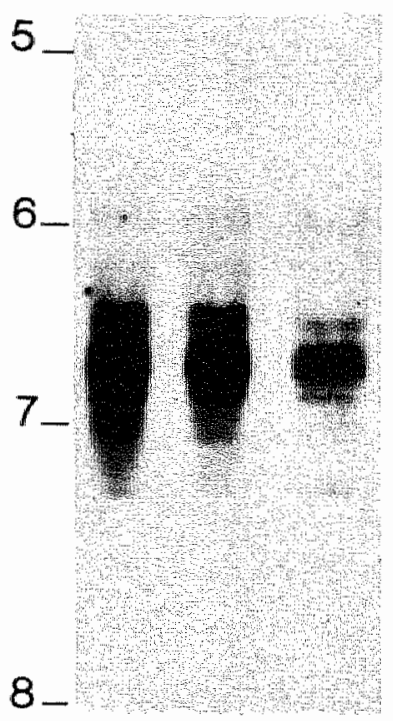

day $\begin{array}{lll}16 & 24 & 35\end{array}$
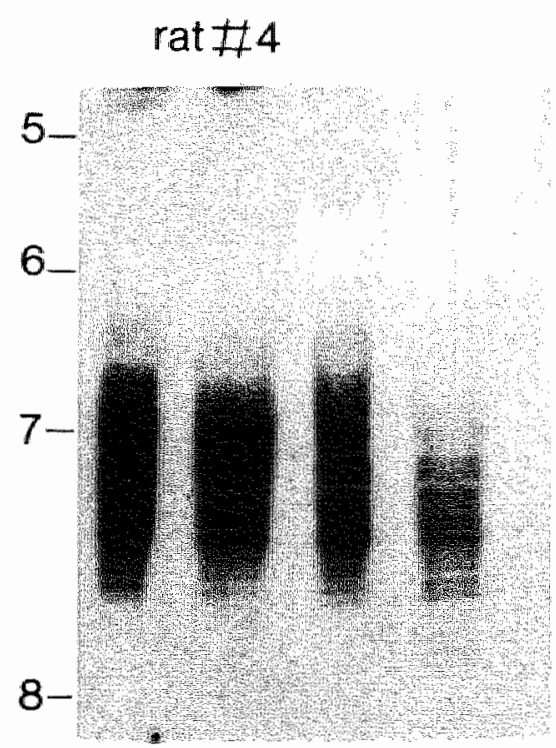

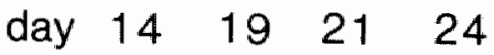

Fig. 6 IEF patterns from our individual Lewis rats with EAMG induced by immunization with $15 \mu \mathrm{g}$. Torpedo AChR. Animals were bled at several time intervals after injection as indicated. Five $\mu$ l of serum from each rat was focused and reacted with ${ }^{125}$ I- $Q$-BGT labeled Torpedo AChR. 
Lewis rats

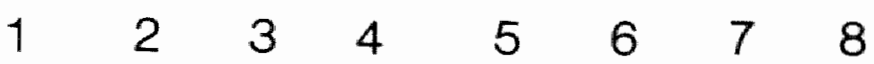

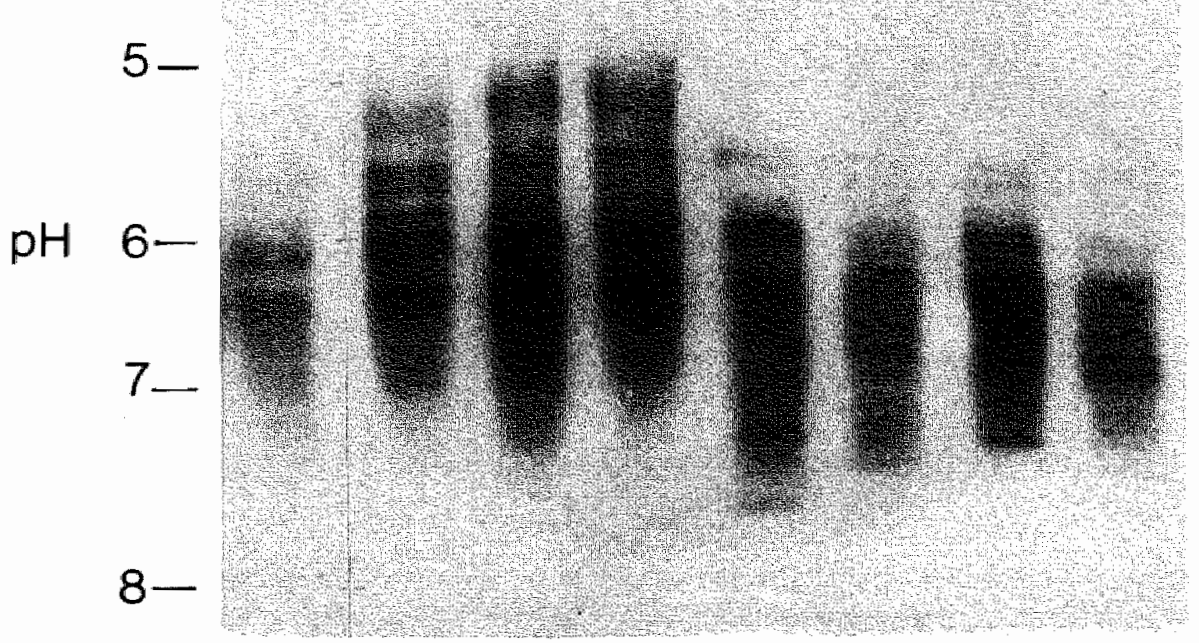

Fig. 7 IEF patterns of immune sera from Lewis (lanes 1-4) and from Brown Norway rats (lanes 5-8) obtained 42 days postimmunization (15 $\mu \mathrm{g}$ Torpedo $A C h R$ in CFA). The number of bands is similar but the range of pI's differs.

As seen in fig. 8 between 30 and 45 days after immunization of rats with Torpedo $A C h R$ rather identical reactivities are observed against Torpedo $A C h R$; when muscle $A C h R$ is used the bands appear later and are in additon fewer in number. Since we have shown in kinetic experiments (Chapter IV, pg. 86, fig. 1) using Torpedo AChR as immunogen that antibodies cross-reactive with rat $\mathrm{AChR}$ appear late and are present in lower titers compared to antibodies to Torpedo AChR, the differences observed in spectrotypes to Torpedo and rat $\mathrm{AChR}$ appear to be due to differences in concentration rather than restriction in the antibody spectrum. This interpretation is supported by an experiment in which first a serum obtained at 34 days from a rat with chronic EAMG was submitted to preparative isoelectric focusing (for details see material and methods section, p.161)next individual fractions were eluted and assayed for binding to Torpedo and rat $A C h R$ by radioimmunoassay. Antibody activities to both Torpedo and rat AChR coincide.

Our analysis of experimental sera revealed that the antibody response to Torpedo and muscle AChR was of polyclonal origin with a banding pattern characteristic for a given strain. These results indicate that genetic background not only influences immune responsiveness to $\mathrm{AChR}$ but it also affects the $\mathrm{pI}$ of the antibodies produced. 
Torpedo AChR

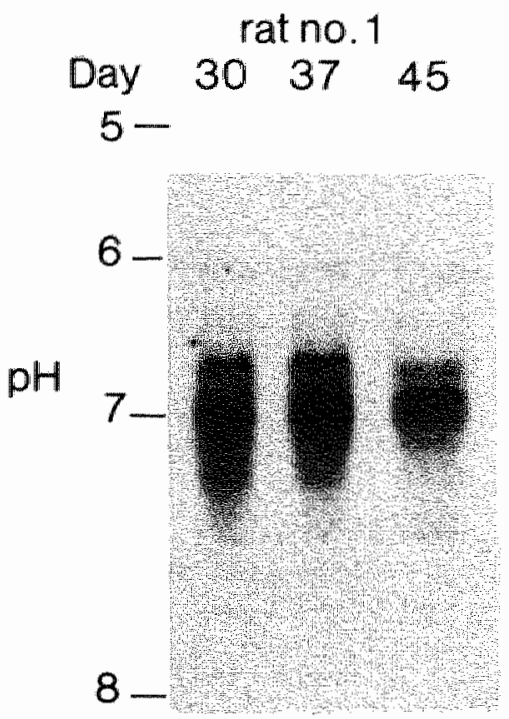

rat no. 2

40

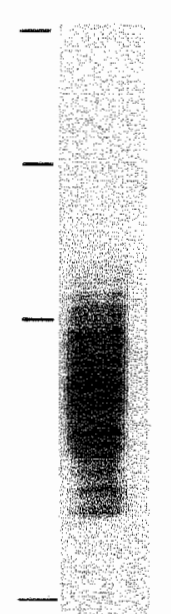

Muscle AChR rat no.1 $30 \quad 37 \quad 45$ rat no. 2 40

Fig. 8 Electrofocusing of sera obtained from two rats at the indicated time points following immunization with Torpedo AChR $\left(15 \mu \mathrm{g}\right.$ in CFA). Focused sera $(5 \mu \mathrm{l})$ were reacted with ${ }^{125}$ I- $\alpha-$ BGT-labeled AChR from either Torpedo or muscle. Note the delayed appearance of anti-muscle AChR bands compared to spectrotypes against Torpedo AChR used for immunization.

Moreover, the combined results indicate that the pIs of anti-AChR antibodies are not the determining factor in their ability to bind the target organs and induce disease. During the course of immunization, a discrete expansion of the number of antibodies is seen and it takes approximately 45 days to obtain the full spectrotype. Others (23) have shown that the peak response to a given antigen levels at 45 days which corresponds with our data. From our sequential studies, the recruitment of clones against Torpedo AChR seemed to preceed the response to self $\mathrm{AChR}$. This asynchrony may be more apparent than real, since our studies by preparative IEF (fig. 9) of serum antibodies show that immune activities to both Torpedo and rat muscle $A C h R$ coincide. This last finding is consistent with the idea that clones reactive with rat $A C h R$ only are not detectable and that cross-reaction between AChR from various species occurs at several determinants on the AChR molecule (1).

\subsubsection{Analysis of tissue deposited antibodies}

In order to determine whether certain antibody specificities are preferentially bound to muscle AChR, we examined the IEF profile of antibodies eluted from the muscles of Lewis rats with EAMG. This is important to determine since it is possible that antibody specificities are not present in serum because they have been bound to AChRs in mus- 


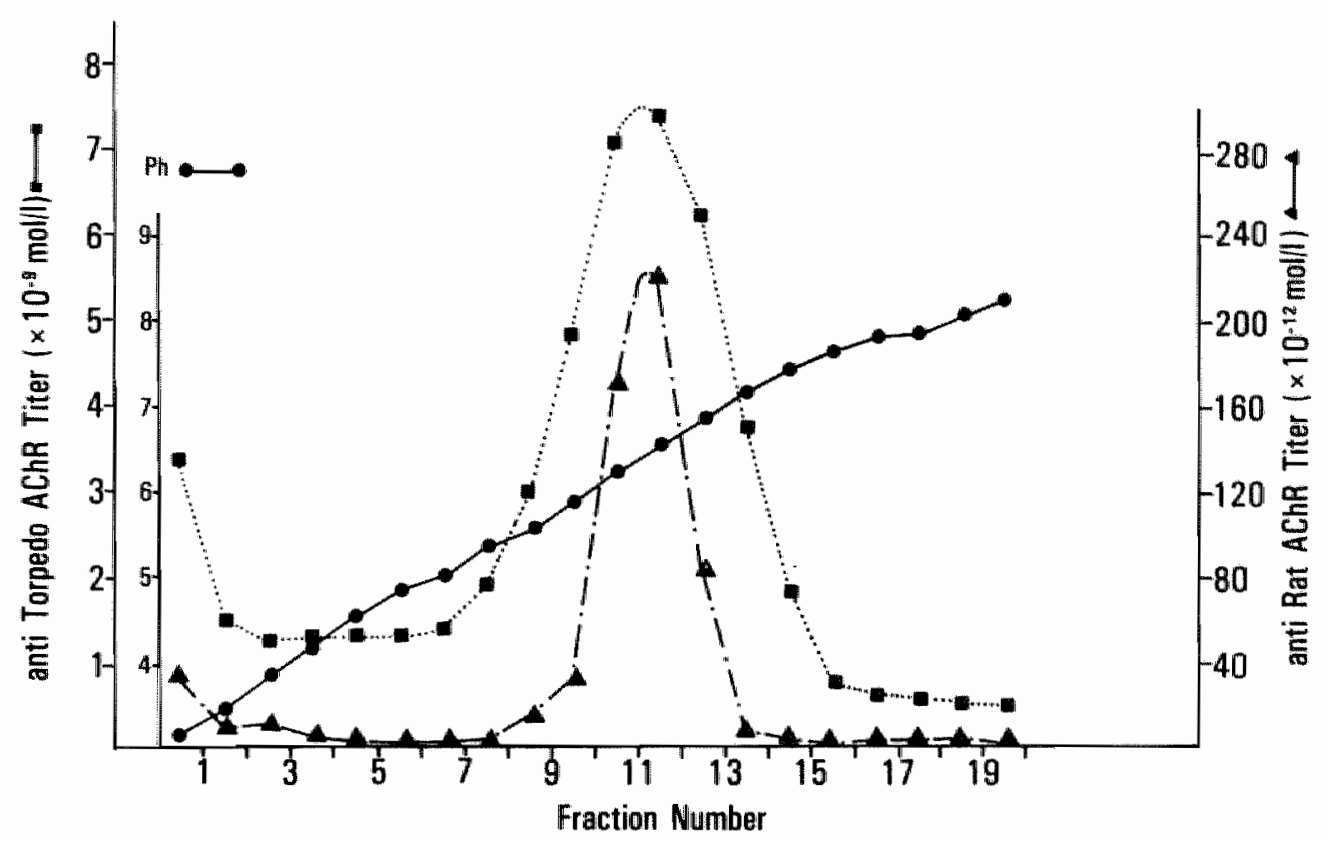

Fig. 9 Preparative IEF of serum from a rat with EAMG. Serum was focused under the pH gradient as indicated. Thereafter, the gel was sliced into 19 bands and each band was eluted with buffer. The dialyzed eluate was subsequently assayed against Torpedo $\mathrm{ACh}$ and rat muscle $A C h R$. This is a representative graph obtained out of five individual sera analyzed.

cle; these antibodies may in fact be quite important in terms of pathogenesis of disease.

The carcasses (muscle and bones) of individual Lewis rats with EAMG were homogenized in a Waring blender in two volumes $10 \mathrm{mM}$ phosphate buffer pH $7.0,100 \mathrm{mM} \mathrm{NaCl}$ and $10 \mathrm{mM}$ $\mathrm{NaN} 3$ (PBS-NaN3) supplemented with protease inhibitors (see material and methods) for one minute at high speed. The homogenate was resuspended in a Waring blender in medium at low speed for 15 seconds and centrifuged at $10,000 \mathrm{~g}$ for $30 \mathrm{~min}$. In order to remove all "'trapped serum" this procedure was repeated six times. Antibody bound AChR complexes were extracted by gently shaking at $4^{\circ} \mathrm{C}$ in 2 volumes of $2 \%$ Triton X-100-PBS-NaN3 in medium supplemented with protease inhibitors for $2 \mathrm{hrs}$. Insoluble material was removed by centrifugation first at low speed $(10,000 \mathrm{~g}, 30 \mathrm{~min})$, then high speed contrifugation $(100,000 \mathrm{~g}, 30 \mathrm{~min})$. The supernatant was incubated with $0.5 \mathrm{ml}$ goat anti rabbit IgG coupled to Sepharose CL4B $(10 \mathrm{mg} \mathrm{IgG/ml} \mathrm{of}$ gel) overnight at $4^{\circ} \mathrm{C}$. The immunoabsorbent was washed with $0.5 \%$ Triton $\mathrm{X}-100$ in PBS. Finally, bound anti-AChR antibody as well as AChR were eluted with $0.1 \mathrm{M}$ glycine-HCl buffer $\mathrm{pH}$ 2.8 and neutralized immediately with $3 \mathrm{M}$ Tris- $\mathrm{HCl}, \mathrm{pH} 10$.

To monitor any possible contamination of the extract with anti-AChR antibody in "trapped serum" we injected a rat six hours prior to sacrifice with ${ }^{125} \mathrm{I}$ labeled rat $\lg \mathrm{G}\left(2,6 \mu \mathrm{g}, 6 \times 10^{8}\right.$ cpm). We found no radioactivity in the final Sepharose-eluted material prepared as described above, thus precluding contamination of the tissue eluate with serum antibodies. 


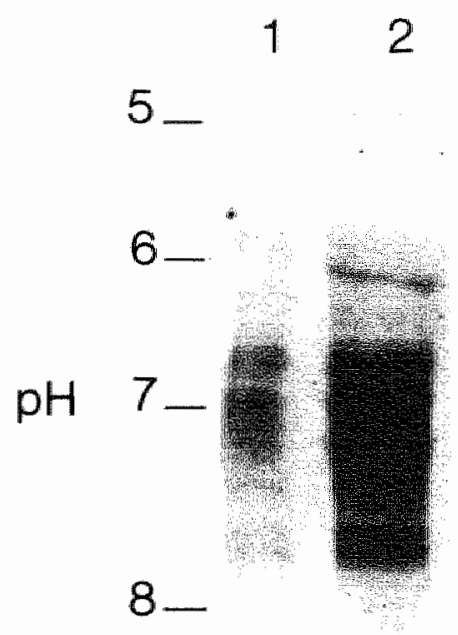

Fig. 10 Comparison of IEF profiles of serum antibodies versus antibodies eluted from a diseased animal (EAMG). After focusing both serum (lane 2) and tissue eluate (lane 1) following focusing were reacted with ${ }^{125}$ I- $\alpha$-BGT Torpedo AChR.

Results and comments.

As depicted in fig. 10 the profiles obtained with antibody eluates from the muscles of rats with EAMG did not differ from the profile of serum antibodies of the same animal. Thus, the cross-reacting antibodies eluted from AChRs at the neuromuscular endplate displayed a similar banding pattern to the circulating antibodies to rat $A C h R$ and were also cross-reacting with Torpedo $A C h R$. These observations are important for several reasons: first, they show that the spectrotype of serum antibodies is identical to that of antibodies reacting with the target organ. Second, all clones reacting with self are activated by the xenogeneic antigen. Finally, no particular class or subclass is responsible for the induction of EAMG. Although the majority of the antibody clones appeared to be represented at the neuromuscular junction of myasthenic animals, this does not necessarily imply that the antibody response to Torpedo and muscle $A C h R$ are quantitatively similar. In fact the serum antibody titer to muscle AChR is only a fraction ( $\pm 0.5 \%$ ) of the titer to Torpedo AChR used as immunogen (1). However, the neuromuscular endplate acts as an in vivo immuno absorbent for cross-reactive anti-AChR antibodies.

\subsection{DISCUSSION}

The muscular weakness characteristic of myasthenia gravis and its experimental animal model is caused by autoantibodies to acethylcholine receptors in skeletal muscle (1). The primary effect of these antibodies is to reduce the amount of receptor at the neuromuscular endplate $(1,4)$. We investigated the properties and specificities of these 
antibodies that determine the severity of disease, c.q. the amount of $A C h R$ loss from muscle. The characteristics of antibodies are discussed in terms of titer, specificity, isotypes and spectrotypes. The autoimmune attack at the neuromuscular endplate also induces reactive changes in the muscle cells which are also important in the disease process.

There is a correlation between total anti-AChR antibody concentration in serum and severity of muscular weakness. Animals immunized with $5 \mu \mathrm{g}$ AChR have lower anti$A C h R$ antibody titers and less severe disease than rats immunized with $10 \mu \mathrm{g}$ AChR (see chapter IV). With higher doses of AChR ( $15 \mu \mathrm{g}$ ) the anti-AChR antibody titers further increase, but no further AChR loss from muscle is seen.

Apart from antibody concentration antibody specificity may influence the severity of disease. Indeed, antibodies against the main immunogenic region on the $\alpha$-subunits are pathogenic since antibodies with this specificity are able to cross-link receptors at the muscle membrane and reduce the number AChR at the neuromuscular endplate, whereas antibodies against other subunits do not cross-link receptors $(18,20)$. Antibodies against the MIR are the most frequent specificity $(8,9)$ in both $M G$ and EAMG. However, since no variation in antibody specificity occurs during the disease process (9) it is unlikelly that variation in the titer anti-MIR antibodies influences disease severity. It is therefore necessary to analyse the role of antibodies with other specificities. In the previous chapter (IV) we have demonstrated that antibodies against reduced carboxymethylated AChR (RCM-AChR) are not pathogenic because they bind mainly to the cytoplasmic surface of AChRs. Since antibodies do not enter cells, antiRCM-AChR antibodies are not pathogenic. As shown in the previous chapter boosting animals with RCM-AChR following a primary immunization with native $A C h R$ does not significantly alter the disease process compared to two immunizations with native AChR. Such alterations in antibody specificities in the presence of an excess of antiMIR antibodies does not affect the antibody attack at the endplates. A third specificity of antibodies that may influence disease are antibodies that inhibit receptor function. This category of antibodies can be divided into a population of antibodies directed at the acetylcholine binding sites and antibodies that influence directly or allosterically the ion channel opening (18). We were not able to demonstrate high titer antibodies against the acetylcholine binding site in the serum of our rats with chronic EAMG using a solid phase assay system. In the past several groups demonstrated anti-acetylcholine binding site antibodies using immunoprecipitation assays, sucrose gradients $(13,24-29)$ or a DEAE disc assay. In the immunoprecipitation assays, receptors may become aggregated by antibodies, resulting in an impaired acces of radiolabeled $\alpha$-BGT or acetylcholine. In the disc assay $\alpha$-BGT-ACh $R$ complexes could be prevented from binding to the discs by serum proteins. Although for the disc assay Claudio et al. carefully titrated the assay system when no such interference was seen. The inhibition of toxin binding is only seen at high serum concentrations. Finally Barkas et al. unequivocally demonstrated that inhibition of toxin binding can be mediated by antibodies which are not directed against the toxin-binding sites (30). 
In our solid phase assay system (ELISA) no substances could be found that intefere with the binding of $\alpha$-BGT to the solid phase AChR. The binding of $\alpha$-BGT however, can be effectively inhibited by acetylcholine (fig. 1) or its analogues (results not shown) which demonstrated that the acetylcholine binding site was oriented in such a way that $\alpha$-BGT or antibodies to the acetylcholine binding site, if present, could bind.

Antibodies that effect $\mathrm{AChR}$ function by interfering with the ionchannel function are also not widely represented in the polyclonal response against AChR. Only 2 of 25 MABs tested by Lindstrom et al. interfere with receptor function perhaps by occluding the lumen of the channel (18). Since a panel of monoclonal antibodies may be taken to be representative for the serum polyclonal response it is unlikely that antibodies that interfere with AChR function are important in EAMG. In MG antibodies that possibly directly affect receptor function by virtue of their binding to the $\alpha$-BGT binding site have been demonstrated using immunoprecipitation assays (31-34). As mentioned above, this result should be interpretated with caution of possible methodological errors. Moreover, no good correlation was found between the titer of antibodies against the acetylcholine binding site and the disease severity (34), with a larger overlap between the different stages of disease.

Since the most frequent specificity of antibodies is directed towards the MIR which renders these antibodies important in terms of pathogenesis and beceause these antibodies are circulating in large excess over the amount of $\mathrm{AChR}$ in muscle, parameters other than titer or antibody specificity determine disease severity. We therefore analyzed the diversity of the antibody response in terms of variable region variability by isoelectric focusing. In all EAMG sera tested, the immune response against Torpedo AChR is polyclonal, this means that antibodies against similar antigenic determinants of Torpedo AChR are produced by different B cell clones. The full spectrotype was expressed early after immunization and remained constant during the immunization period (similar results have been obtained by $L$. Nye (35) in rats immunized with thyroglobulin). The results show that the same B cell clones produced anti-Torpedo $A C h R$ antibodies in the period preceeding the disease and during the chronic phase of the disease (starting at about day 30 after immunization). These results suggest that the spectrotype of anti-Torpedo $\mathrm{AChR}$ antibodies does not affect the expression of the disease.

The antibodies reactive with rat muscle $\mathrm{AChR}$ are a cross-reacting fraction of those to the Torpedo AChR used as immunogens. The population of antibodies bound to receptors in muscle is the same as the population of antibodies to Torpedo AChR in serum and cross-reactive with muscle AChR. This refutes the existence of a particular antibody clone with a greater affinity or specificity for the muscle AChR than others and, therefore, of higher pathogenic potential. This conclusion is consistent with the observation that there was no correlation between the pattern of anti-AChR specificities (as analyzed with MABs) in MG patients and the severity of their muscular weaknes (9). These conclusions are important because the correlation between serum anti-AChR concentration and weakness in MG is poor (36-40), and one possible explanation could 
be that only a small fraction of the anti-AChR antibodies is pathogenetically significant. Our experiments provide additional evidence that this is not the case. Thus, it would appear that diverse clinical responses to the same serum concentration of antibodies is influenced by other factors such as acetylcholine synthesis and release or AChR synthesis or destruction rates.

\subsection{SUMMARY AND CONCLUSIONS}

In this chapter anti-AChR antibodies that mediate $A C h R$ loss from muscle in rats with chronic EAMG were examined in terms of specificity and spectrotype (isoelectric point). This analysis yielded two conclusions :

1. Antibodies to the acetylcholine binding site on AChR were hardly detectable. These data are compatible with the observations that the main category of antibodies that induce EAMG are directed against the MIR.

2. Analysis of antibody diversity revealed that the serum anti-AChR antbodies are polyclonal. Sequential studies on sera from rats with chronic EAMG showed the full spectrotype to be expressed early after immunization and not to change with the onset of disease suggesting that the spectrotype of anti Torpedo AChR antibodies does not influence disease. This was confirmed by finding the spectrotype of anti rat muscle AChR antibodies eluted from the neuromuscular junction to be identical with those of the serum. 


\section{References}

1. Lindstrom JM. Autoimmune response to acetylcholine receptors in myasthenia gravis and its animal model. Adv. Immunol. 27: 1-50, 1979.

2. Kao $l$ and Drachman DB. Myasthenic immunoglobulin accelerates acetylcholine receptor degradating. Science 196: 527-529, 1977 .

3. Heinemann $S$, Bevan $S$, Kullber $\mathbb{R}$, Lindstrom JM and Rice $J$. Modulation of acetylcholine receptor by antibody against the receptor. Proc. Natl. Acad. Sci. USA 74: 3090-3094, 1977.

4. Heinemann S, Merlie $\mathrm{J}$ and Lindstrom JM. Modulation of acetylcholine receptor in rat diaphragm by antireceptor sera. Nature (London) 274: 65-67, 1978.

5. Engel AG, Lambert EH and Howard FM. Immune complexes (IgG and C3) at the motor endplate in myasthenia gravis. Ultrastructural and light microscopic localization and electrophysiologic correlatilon. Mayo Clin.Proc. 52: 267-280, 1977.

6. Engel AG, Lindstrom JM, Lambert EH and Lennon VA. Ultrastructural Iocalization of the acetylcholine receptor in myasthenia gravis and in the experimental autoimmune model. Neurology 27: $307-315,1977$.

7. Fumagalli $G$, Engel $A G$ and Lindstrom JM. Ultrastructural aspects of acetylcholine receptor turnover at the normal endplate and in autoimmune myasthenia grawis. J. Neuropathol. Exp. Neurol. 41: $567-579,1982$.

8. Tzartos SJ and Lindstrom JM. Monoclonal antibodies used to probe acetylcholine receptor structure: Localization of the main immunogenic region and detection of similarities between subunits. Proc. Natl. Acad. Sci. 77: 755-759, 1980.

9. Tzartos SJ, Seybold ME and Lindstrom JM. Specificities of antibodies to acetylcholine receptors in sera from myasthenia gravis patients measured by monoclonal antibodies. Proc. Natl. Acad. Sci. 79: $188-192,1982$.

10. Lennon VA and Lambert EH. Myasthenia grawis induced by monoclonal antibodies to acetylcholine receptor. Nature 285: 238-240, 1980.

11. Richman DP, Gomez CM, Berman PW, Burres SA, Fitch FN and Arnason BGW. Monoclonal antiacetylcholine receptor antibodies can cause experimental myasthenia. Nature 286: 738-739, 1980.

12. Bartfeld D and Fuchs S. Specific immunosuppression of experimental autoimmune myasthenia gravis by denatured acetylcholine receptor. Proc. Natl. Acad. Sci. USA 75: 4006-4010, 1978.

13. Claudio $T$ and Raftery MA. Inhibition of $\alpha$-bungarotoxin binding to acetylcholine receptors by antisera from animals with experimental autoimmune myasthenia gravis. J. Supramol. Structure 14: 267-279, 1980.

14. Vincent A. Immunology of acetylcholine receptors in relation to myasthenia gravis. Phys. Rev. 60: 756-824, 1980.

15. Awdeh ZL, Williamson AR and Askonas BA. Isoelectric focusing in polyacrylamide gell and its aplications to immunoglobullins. Nature (London): 219: 66-67, 1968.

16. Lindstrom JM, Einarson B and Merlie J. Immunization of rats with polypeptide chains from Torpedo acetylcholine receptor causes an autoimmune response to receptors in rat muscle. Proc. Natl. Acad. Sci. USA 75: 769-773, 1978.

17. Tzartos SJ and Changeux JP ." High affinity binding of $\alpha$-bungarotoxin to the purified $\alpha$-subunit and to its 27000 -dalton proteolytic peptide from Torpedo marmorata acetylcholine receptor. Requirement for sodium dodecyl sulphate. EMBO J. 2: 381-387, 1983.

18. Lindstrom $J M$, Tzartos $S$ and Gullick W. Structure and function of the acetylcholime receptor molectule studies using monoclonal antibodies. Ann. NY Acad. Sci. 377: 1-19, 1981.

19. Tzartos SJ, Swanson LW, Langeberg LK and Lindstrom JM. Monoclonal antibodies to acetylcholine receptors from human and bovine muscles and Torpedo electric organ as probes for receptor structure and model autoantibodies. Submitted.

20. Conti-Tronconi B, Tzartos S and Lindstrom JM. Monoclonal antibodies as probes of acetylcholine receptor. I1. Binding to native receptor. Biochemistry 20: 2181-2191, 1981.

21. Gomez $\mathrm{C}$ and Richman $\mathrm{D}$. Anti-acetylcholine receptor antibodies directed against the $\alpha$-bungarotoxin binding site induce a unique form of experimental myasthenia. Proc. Natl. Acad. Sci. 80: 4089-4093, 1983 .

22. Williamson AR. Isoelectric focusing of immunoglobulins. In: Handbook of experimental immunology, 
DM Weiz Ed., Blackwell Scientific Publications, 3 rd ed., p. $9,24,1978$.

23. Roitt IM. Essential Immunology. (3rd ed.). Blackwell Scientific Publication, Oxford, p. 82, 1977.

24. Sanders DB, Schleifer LS, Eldefrawi ME, Norcross NL and Cobb EE. An immunologically induced defect of neuromuscular transmission in rats and rabbits. Ann. NY Acad. Sci. 274: 319-336, 1976.

25. Penn AS, Chang HW, Lovelace RE, Niemi W and Miranda A. Antibodies to acetylcholine receptor: in rabbits: immunochemical and electrophysiological studies. Ann. NY Acad. Sci. 274: 354-376, 1976.

26. Zurn AD and Fulpius BW. Study of two different subpopulations of anti-acetylcholine receptor antibodies in a rabbit with experimental autoimmune myasthenia grawis. Eur. J. Immunol. 8: 529-532, 1977.

27. Alharonov A, Tarrab-Hazdai R, Silman $I$ and Fuchs $S$. Immunochemical studies on acetylcholine receptor from Torpedo californica. Immunochemistry 14: 129-137, 1977.

28. Eldefrawi $M E$. Experimental autoimmune myasthenia gravis: The rabbit as an animal model. Fed. Proc. 37: 2823-2827, 1978.

29. Karlin A, Holtzman E, Valderrama $R$, Damle V, Hsu $\mathbf{K}$ and Reyes $\mathbf{F}$. Binding of antibodies to acetylcholine receptors in Electrophorus and Torpedo electroplax membranes. J. Cell. Biol. 76: $577-593,1978$.

30. Barkas T, Gairns JM, Kerr JM, Coggins JR and Simpson JA. Alfa bungarotoxin binding to the nicotin acetylcholine receptor is inhibited by two distinct subpopulations of anti-receptor antibodies. Eur.J. Immunol. 12: 757-761, 1982 .

31. Appel SH, Almon RR and Levy N. Acetylcholine receptor antibodies in myasthenia gravis. N. Engl. J. Med. $293: 760-761,1975$.

32. Mittag $T$, Kornfeld $P$, Tormay $A$ and Woo $C$. Detection of anti-acetylcholin receptor factors in serum and thymus from patients with myasthenia gravis. N. Engl. J. Med. 294: 691-694, 1976.

33. Fulpius $B W$, Miskin $R$ and Reich $\mathbb{E}$. Antibodies from myasthenic patients that compete with cholinergic agents for binding to nicotinic receptors. Proc. Natl. Acad. Sci. USA 77: 4326-4330, 1980.

34. Drachman DB, Adams RN, Josifek LF and Self SG. Functional activities of autoantibodies to acetylcholine receptors and the clinical severity of myasthenia gravis. New Engl. J. Med. 307: 769-775, 1982.

35. Nye $L$, De Carvalho LP and Roitt IM. An investigation in the clonality of human autoimmune thyroglobulin antibodies and their light chains. Clin. Exp. Immunol. 46: 161-170, 1981.

36. Lindstrom JM, Seybold ME, Lennon VA, Whittingham S and Duane D. Antibody to acetylcholine receptor in myasthenia gravis. Prevalence, clinical correlates and diagnostic value. Neurology 26: 1054-1059, 1976.

37. Lefvert AK, Bergstrom K, Matell G, Osterman PO and Pirskanen. Determination of acetylcholine receptor antibody in myasthenia gravis: clinical usefulness and pathogenic implications. J. Neurol.Neurosurg. Phsychiatry $41: 394-403,1978$.

38. Limburg PC, Hummel E, The TH and Oosterhuis HJGH. Anti-acetylcholine receptor antibodies in

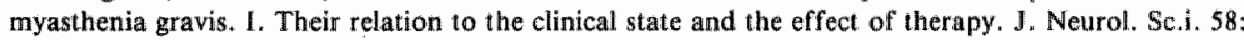
$357-370,1983$.

39. Compston DAS, Vincent A, Newson-Davis $J$ and Batchelor JR. Clinical, pathological, HLA antigen and immunological evidence for disease heterogeneity in myasthenia gravis. Brain 103: 579-601, 1980.

40. Oosterhuis HJGH. Myasthenia Gravis. In: Clinical Neurology and Neurosurgery monographs. GH Glaser et al. (Eds.). Churchill Livingstone, p. 109, 1984. 



\section{CHAPTER VI}

\section{Effect of AChR-synthesis in the severity of EAMG}

\subsection{INTRODUCTION}

Conceptually myasthenia gravis is determined by the immune response to the acetylcholine receptor (AChR) and the capacity of the target organ to withstand the immunological assault. Immunological factors such as antibody titer and antibody specificity are important determinants in causing AChR loss. Conversely the rate of acetylcholine synthesis should also influence myasthenia. The present therapeutic strategies in myasthenia gravis are designed to suppress antibody or inflammatory reactions by aspecific means, e.g. plasmapheresis and immunosuppressive drugs; alternatively the amount of acetylcholine present at the motor endplate is enhanced pharmacologically ( 1$)$.

Although the issue of specific immunotherapy with antiidiotypic antibodies has been raised in EAMG these results are by and large inconclusive in terms of ameliorating the disease although crossreactive idiotypes have been demonstrated (2). We therefore raised the question whether procedures known to stimulate protein synthesis in general and AChR in particular influenced EAMG. For this reason the effect of unilateral limb denervation and administration of anabolic steroids in the AChR loss in EAMG was examined. The ratio for choosing these procedures was as follows. Although in normal muscles all $A C h R$ resides at the neuromuscular junction, denervation of muscle tissue results not only in an increased turnover of $\mathrm{AChR}$ at the neuromuscular junction but also in a spread of $A C h R$ to extrajunctional sites; the entire muscle plasmamembrane may in fact be covered with $A C h R$. The postsynaptic area membrane remains however an area packed with $A C h R$ and thus rapid replacement of AChR occurs at the former junctional area (3).

Apart from denervation the effect of anabolic steroids (nandrolone) on EAMG was examined for two reasons. First anabolic steroids thave a clearcut effect on muscle mass and androgens (such as danazol) have been shown to enhance the synthesis of deficient proteins in patients with hereditary angioneurotic edema, Clq esterase inhibitor (4), $\alpha 1$-antitrypsin deficiency (5) or deficient coagulation factors (6). Thus we assumed it might also influence $A C h \mathbb{R}$ synthesis in EAMG. In addition however epidemiological evidence in humans and experimental evidence of spontaneous animal models of autoimmune diseases show sex hormones to play a role in a variety of autoimmune diseases including myasthenia gravis.

Myasthenia gravis has a female preponderance $(3: 1$, females to males)(7). Other autoimmune diseases in which immune abnormalities are predominantly present in the female are systemic lupus erythematosus (SLE) (10:1) (8), rheumatoid arthritis (3:1) 
(9), scleroderma (3:1) (10), Sjogren's syndrom (9:1) (11), cbronic active hepatitis (non infectious origin) (9:1) (12), primary biliary cirrhosis (9:1) (13), chronic idiopathic thrombocytopenic purpura (4:1) (14) and another receptor autoimmune disease: Graves' disease (6:1) (15). In addition, the age of the patient plays a role in the manifestation of the disease. The ratio of 10:1 for female to male SLE applies only to females in the childbearing years (8). When prepubertal and post-menopausal females are included this ratio falls to $3: 1$ (16). These epidemiological data suggest that both in female and male oestrogens or progesterons may have a deleterious effect on these autoimmune diseases. Patients with SLE for example have an increased hydroxylation of estradiol at $\mathrm{C}-16$ towards the more feminizing metabolites $16 \alpha$-hydroxyestrone and estriol. These metabolites might contribute to the severity of SLE (17, 18). Androgens in contrast to female sex hormones have been shown to have protective effects against the manifestation of autoimmune diseases in animal models. Nandrolone (19-nortesterone) and 5- $\alpha$-dihydrotestosterone given to female $N Z B / N Z W$ mice (murine model for systemic lupus erythematosus) improved survival, reduced antiDNA autoantibody levels and glomerulonephritis $(19,20)$. The administration of the oestrogen antagonist nafoxidine retarded the development of murine SLE (21). Based on these beneficial effects of androgens on autoimmune disease and their anabolic capacities we analyzed a possible effect of nandrolone on EAMG.

\subsection{EFFECT OF UNILATERAL DENERVATION (N. ISCHIADICUS) ON THE SEVERITY OF EAMG INDUCED BY PASSIVE TRANSFER OF MONOCLONAL ANTIBODY}

In order to analyse the effect of enhanced AChR synthesis on acute EAMG we denervated the left hindleg of 8 female Lewis rats by cutting the left nervus ischiadicus. All animals were operated under ether anesthesia. The skin was incised on the midline over the lower back. The incised skin was moved to the left of the musculus gluteus maximus which was incised. Under that muscle, the $\mathrm{n}$. ischiadicus, was removed over a length of $5 \mathrm{~mm}$. The muscle was not sutured; the skin was closed with three metal clips. On day 8 after denervation four animals (group A) were injected intraperitoneally with 40 pmol of anti AChR monoclonal antibody directed against the MIR (MAB no. 35; see table material and methods section, p. ); the 4 other rats (group B) were injected with an irrelevant monoclonal antibody $(100 \mu \mathrm{g}$ of a monoclonal anti-human thyroglobulin antibody). Fourty-eight hours later all rats were sacrificed; the skin was removed and the body was divided above the place of insertion of the hindleg muscles. Both legs were then separated from the backbone and frozen on dry ice. AChR and anti AChR antibody concentration was measured in each leg, according to the methods described in the material and methods section (p.161). 
Table I. Passive transfer of EAMG by monoclonal antibody into rats with unilaterally denervated (left) legs.

\begin{tabular}{|c|c|c|c|c|c|}
\hline group & $\mathrm{MAB}$ & $\operatorname{leg}^{b}$ & $\begin{array}{l}\text { concentration } \\
\text { of } \mathrm{AChR} \\
(\mathrm{pmol} / \mathrm{leg})\end{array}$ & $\begin{array}{l}\text { concentration } \\
\text { of anti-AChR ab } \\
\text { (pmol/leg) }\end{array}$ & $\begin{array}{l}\text { \% AChR } \\
\text { complexed } \\
\text { with } a b\end{array}$ \\
\hline \multirow[t]{2}{*}{$A(n=4)$} & anti-TG & left & $24.5 \pm 1.0$ & 0 & 0 \\
\hline & & right & $6.2 \pm 0.4$ & 0 & 0 \\
\hline \multirow[t]{2}{*}{$B(n=4)$} & anti-AChR & left & $24.2 \pm 1.4$ & $0.62 \pm 0.08$ & 2.6 \\
\hline & & right & $4.7 \pm 0.5$ & $0.31 \pm 0.13$ & 6.5 \\
\hline
\end{tabular}

a) the rats were infused i.p. with monoclonal anti-thyroglobulin antibody (anti-TG) or monoclonal, anti-acetylcholine receptor antibody (anti-AChR).

b) the left lleg was denervated by cutting the nervus ischiadicus.

c) concentrations of $A C h R$ and anti-AChR antibody were measured by radioimmunassay, results were expressed in $\mathrm{p}$ mol/leg (mean \pm S.E.)

\section{Results and comments.}

Both groups of rats had a higher concentration of $\mathrm{AChR}$ in the denervated leg when compared to the normal leg indicating that the denervation was complete.

Rats infused with monoclonal anti AChR antibody (group B) had less AChRs in their normally innervated legs than animals injected with an irrelevant monoclonal antibody (group A) (n.s.). The denervated legs contained the same amount of AChR in rats infused with anti- $A C h R M A B$ and anti thyroglobulin MAB. The ratio of the AChR content of the denervated leg versus the normal leg, however, was significantly increased in the animals injected with an anti-AChR MAB (5.2 \pm 0.4 , mean \pm SEM) when compared to control animals $(3.9 \pm 0.1)(p<0.05)$. The amount of anti-AChR antibody deposited in the denervated leg was twice that found in the normal leg. The number of AChR covered with antibody was 2.5 times higher $(6.5 \%)$ in the normally innervated leg than in the denervated leg $(2.6 \%)$ (Table I). These experiments suggest that denervation prevents AChR loss because of an increased AChR turnover in the denervated leg. Possibly this protective effect was due to the low AChR occupancy with antibody in the denervated leg. It was therefore necessary to perform the same experiments in large antibody excess. These high antibody levels can be easily achieved in chronic EAMG.

\subsection{EFFECT OF UNILATERAL DENERVATION (N. ISCHIACHIDUS) ON THE SEVERITY OF EAMG INDUCED BY ACTIVE IMMUNIZATION WITH TORPEDO AChR}

In order to further analyze the protective effect of denervation on antibody mediated AchR loss observed in the experiment described above, rats were subjected to unilateral limb denervation prior to the induction of chronic EAMG. Six female Lewis rats were 
Table II: Effect of unilateral limb denervation on the AChR loss in chronic EAMG at

\begin{tabular}{|c|c|c|c|c|}
\hline & $\begin{array}{l}\% \text { AChR loss } \\
\text { from muscle }\end{array}$ & $\begin{array}{l}\text { AChR concen- } \\
\text { tration }^{b} \\
\text { (pmol/leg) }^{-}\end{array}$ & $\begin{array}{l}\text { Concentration } \\
\text { of anti-AChR } \\
a^{b} \text { (pmol/leg) }\end{array}$ & $\begin{array}{l}\text { \% AChR com- } \\
\text { plexed with } \\
\text { (pmol/leg) }\end{array}$ \\
\hline $\begin{array}{l}\text { normal leg } \\
\text { denervated leg }\end{array}$ & $\begin{array}{l}53.0 \pm 4.8 \\
13.5 \pm 4.8\end{array}$ & $\begin{array}{r}2.5 \pm 0.25 \\
12.3 \pm 1.12\end{array}$ & $\begin{array}{l}0.67 \pm 0.16 \\
2.10 \pm 0.50\end{array}$ & $\begin{array}{l}27.0 \pm 6 \\
17.1 \pm 3.8\end{array}$ \\
\hline
\end{tabular}

a) AChR loss (mean \pm S.E.M.) from muscle (leg) in animals immunized with AChR in CFA is given in $\%$ of AChR concentration of control animals immunized with CFA only.

b) Actually measured in the experimental animals.

denervated unilaterally by cutting the left ischiadic nerve. Four animals were immunized that same day with $15 \mu \mathrm{g} \mathrm{AChR} \mathrm{in} \mathrm{CFA} \mathrm{and} \mathrm{two} \mathrm{rats} \mathrm{were} \mathrm{injected} \mathrm{with} \mathrm{CFA} \mathrm{alone.}$ All animals were sacrificed 35 days after immunization. AChR and AChR-antibody concentration was measured in each leg.

\section{Results and comments.}

All animals immunized with AChR in CFA had high anti-Torpedo AChR antibody titers $(5.2 \pm 0.3 \mu \mathrm{M})$ in the serum whereas control animals did not have circulating anti-AChR antibodies. All animals immunized with AChR showed significant AChR loss in their normally innervated legs whereas the denervated legs showed minimal AChR loss ( $p<0.005$ ) (table II). The ratio of the AChR content of the denervated leg versus the normal leg was $4.9 \pm 0,17$ (mean \pm S.E.).

The amount of antibody deposited in the denervated leg is 3 times higher compared to the innervated leg $(\mathrm{p}<0.01)$. The AChR occupancy with antibody however, is somewhat lower in the denervated leg since it contains five times more $\mathrm{AChR}$ than the normally innervated leg. This lower AChR occupancy agrees with the fact that in spite of the large circulating antibody excess the AChR incorporation in the muscle membrane occurs faster in the denervated leg.

This experiment and the previous one (see table I) demonstrate that a non-immunological factor such as the rate of $A C h R$ resynthesis is a limiting factor in chronic EAMG. This factor may account for differences in susceptibility observed between different animal strains from the same species. It is also likely that during an autoimmune attack against the neuromuscular endplate, $A C h R$ synthesis is increased until a new equilibrium between synthesis and antibody mediated degradation is achieved.

\subsection{EFFECT OF ANABOLIC STEROIDS NANDROLONE ON EAMG}

Female Lewis rats were immunized with $15 \mu \mathrm{g}$ of Torpedo AChR incorporated in CFA. One group of animals (group $A, n=5$ )was treated with nandrolone $(40 \mathrm{mg} / \mathrm{kg}$, incor- 
Table III: Effect of nandrolone on the immune response to AChR in Lewis rats

Serum antibody titer against

\begin{tabular}{llrr} 
Group & $\mathrm{n}$ & Torpedo $(\mathrm{nM})$ & \multicolumn{1}{c}{ rat (nM) } \\
\hline A (nandrolone) & 5 & $898 \pm 130$ & $3,76 \pm 2.0$ \\
B (arachis oil) & 4 & $1670 \pm 523$ & $10,90 \pm 4.1$
\end{tabular}

All animals (group A and B) were immunized with $15 \mu \mathrm{g}$ of Torpedo AChR on day 0. Group A was treated on day 0,14 and 28 with $40 \mathrm{mg} / \mathrm{kg}$ of nandrolone in arachis oil; group $B$ was given arachis oil only on days 0,14 and 28 . Serum antibody titers were measured onday 28 after immunization.

porated in Arachis oily on days 0, 14 and 28 after immunization with AChR. A second group (group $B, n=4$ ) was treated with Arachis oil only according to the same treatment schedule. Control animals (not immunized with $\mathrm{AChR}$ ) received nandrolone or arachis oil only. All animals were bled 28 days after immunization with $A C h R$ and sacrificed 4 days later. Anti-AChR antibody titers were determined in the serum by radioimmunoassay; $A C h R$ and anti-AChR antibody complexes were measured in muscle tissue (see material and methods section, p.161).

\section{Results and comments.}

One month after immunization with $A C h \mathbb{R}$ the nandrolone treated rats (group A) had significantly lower serum anti-Torpedo $A C h R$ and anti-rat $A C h R$ antibody titers than animals in the control group (group B) ( $p<0.01$ ). The serum anti-rat $A C h R$ titers were threefold higher in the animals treated with arachis oil only (table III). None of the five nandrolone treated rats developed clinical signs of EAMG; 3 out of 4 rats injected with Arachis oil, however, showed severe EAMG one month after immunization with Torpedo AChR. At that time all animals were sacrificed. A significant difference in weight of the animal carcasses was found between the groups $\mathbf{A}$ and $\mathbf{B}(134,6 \pm 3,5$ gr versus $97,4 \pm 7,7$ gr. respectively) $(\mathrm{p}<0.01)$. The increase in weight after nandrolone treatment was not due to fluid retention but due to a visible increase in the muscular mass.

Next the amount of AChR and anti-AChR antibody complexes was measured in rat muscles. As shown in table IV nandrolone treated animals showed less AChR loss comm pared to the animals treated with arachis oil only (n.s.). Nandrolone had no effect on the $A C h R$ concentration in rats not immunized with Torpedo AChR in CFA as shown by a concentration of $45.6 \pm 2.2 \mathrm{pmol} / \mathrm{leg}(\mathrm{n}=4)$ in rats given nandrolone versus 48 $\pm 3.0 \mathrm{pmol} / \mathrm{leg}$ in rats given arachis oil only $(n=4)$. Striking were the differences in AChR anti-AChR complexes. Nandrolone treated animals of group A had only $44 \%$ of their AChR's covered with antibody whereas in the arachis oil treated (group B) $82,2 \%$ of the receptors was complexed with antibody (table IV). 
Table IV: Effect of nandrolone on EAMG

\begin{tabular}{llll}
\hline group & $\mathrm{n}$ & $\begin{array}{l}\text { clinical } \\
\text { EAMG }\end{array}$ & $\%$ AChR loss \\
& & $\begin{array}{l}\% \text { AChR complexed } \\
\text { with antibody }\end{array}$
\end{tabular}

\begin{tabular}{lllll}
\hline A (nadrolone) & 5 & $0 / 5$ & $43 \pm 5$ & $44.2 \pm 12$ \\
B (arachis oil) & 4 & $3 / 4$ & $53 \pm 3$ & $82.2 \pm 8.6$
\end{tabular}

a) $\mathrm{AChR}$ loss from leg muscle in animals of group $\mathrm{A}$ and $\mathrm{B}$ is given in $\%$ of $\mathrm{AChR}$ concentration of normal rats with nandrolone (controls for group A) or arachis oil (controls for group B) only.

These data suggest that nandrolone is effective in the treatment of EAMG by virtue of an immunosuppressive effect on anti-AChR antibody synthesis. It is also possible that nandrolone stimulates the AChR synthesis after the immune attack on the endpllate, which could account for the low AChR occupancy with antibody.

\subsection{DISCUSSION}

Animals in which the AChR-synthesis in muscle was increased by denervation were protected against $\mathrm{AChR}$ loss in the denervated muscles after injection with monoclonal anti AChR antibody or AChR in CFA.

These experiments clearly demonstrate that non-immunological factors such as AChR synthesis can be rate limiting, in the presence of a limiting amount of (monoclonal) antibody and also in larger (polyclonal) antibody excess after immunization with AChR. Since muscle is capable of large increases in rate of receptor synthesis during embryonal development and" after denervation it is likefy that after an immunologicall attack a reactive increase of $\mathrm{AChR}$ synthesis occurs at the neuromuscular junction.

This proces of antibody mediated attack and AChR synthesis reaches an equilibrium. The set-point of this equilibrium can probably be changed by immunological factors such as an increase in antibody titer or by factors influencing AChR synthesis. These factors have been identified in the central and peripheral nervous system. A small polypeptide with a molecular weight of 1700 , extracted from embryonic chick brain increased both AChR and acetylcholinesterase 3-5 fold (22). Other factors have been partially characterized but the mechanism of action of the various factors remains to be worked out $(23,24)$. Aspecific factors such as the external calcium concentration (25) and cyclic nucleotides are also regulators of $A C h R$ levels.

The finding that non-immunological factors affecting AChR-synthesis have a protective effect against AChR loss from muscle might have important therapeutic implications for myasthenia gravis. The present therapeutic strategies all aim at a decrease in anti-AChR antibody concentration and an increase of the amount of acetylcholine at the neuromuscular endplate; these therapeutic manoeuvres could be supplemented by adding drugs that stimulate AChR synthesis. Candidates are phosphodiesterase in- 
hibitors such as theophillin or coffeine that raise AChR synthesis in culture by increasing intracellular cAMP levels (25). Anabolic steroids such as nandrolone might also be effective by increasing the general protein synthesis.

We therefore examined the effect of nandrolone on the induction of EAMG. Indeed, nandrolone had a clear clinical effect on EAMG. The mechanisms responsible for this protective effect may be dual. First, nandrolone had an immunosuppressive effect on mainly the anti-self AChR antibody titers. These data are in agreement with the immunosuppressive effects of nandrolone on anti-DNA titers and disease in murine systemic lupus erythematosus (20). Secondly, nandrolone has a clear effect on muscle which appeared from an increase in muscular mass. The anabolic effect possibly also protects the animals against clinical signs of EAMG. Nandrolone treated rats however had AChR loss from their muscle, which was however less than in control animals. More striking was the effect on the AChR occupancy with antibody. In spite of anti$A C h R$ antibody excess in their serum the nandrolone treated animals showed a much lower number of $\mathrm{AChR}$ complexed with antibody. This can best be explained by an increase of AChR synthesis induced by nandrolone. These results open new perspectives for the treatment of MG and possible for anti-receptor disease in general. Before a clinical trial is started it will be necessary to analyze whether nandrolone has also a protective effect on ongoing EAMG. Studies with nandrolone in murine SLE suggest that this approach might yield success. (20).

\subsection{SUMMARY AND CONCLUSIONS}

In this chapter the effect of target organ manipulation on EAMG was studied. AChR synthesis was increased in two ways:

1. Unilateral limb denervation by removal of the ischiadic nerve resulted in a significant increase in AChR synthesis. This manoever protected the denervated limb against antibody mediated AChR loss induced by passive transfer of monoclonal anti AChR antibody or by active immunization with AChR.

2. The administration of anabolic steroids protected rats against the induction of clinically apparent EAMG. In the control rats the clinical myasthenia was associated with a $50 \%$ muscle $A C h R$ loss; of the remaining muscle AChR $80 \%$ was complexed with antibody. Compared to the controls the rats treated with anabolic steroids showed significantly less cross reactive antibody in the serum. Striking were the differences in immune complex formation at the neuromuscular junction: the rats treated with anabolic steroids showed somewhat less muscle AChR loss $(43 \%)$ compared to controls $(53 \%)$ but of the remaining muscle AChR only $44 \%$ was complexed to antibody. These results suggest anabolic steroids to be beneficial in rats with chronic EAMG because of decreasing antibody concentration; in addition however a beneficial effect on the increase inAChR synthesis induced by antibody mediated AChR cross linking appears likely. 


\section{References}

1. Oosterhuis HJGH. Myasthenia gravis. In: clinical neurology and neurosurgery monographs. In: Glaser GH et al, eds. Vol. 5, p. 175, 1984.

2. Lennon VA and Lambert EH. Monoclonal antibodies to acetylcholine receptors: evidence for a dominant idjotype and requirement of complement for pathogenecity. Ann. NY Acad. Sci. 377: 77-95, 1981.

3. Levitt TA, Loring RHI and Salpeter MM. Neuronal control of acetylcholine receptor turnover rate at a vertebrate neuromuscular junction. Science 210:550-551, 1980.

4. Gelfand JA, Shering RJ, Alling DW and Frank MM. Treatment of hereditary angioedema with danazol: reversal of clinical and biochemical abnormalities. N. Engl.J. Med. 295: 1444-1448, 1976.

5. Gadek JE, Fulmer JD, Gelfland JA, Frank MM, Petty TL and Crystal RG. Danazol induced augmentation of serum $a-1$-antitrypsin levels in individuals with marked deficiency of this anti-protease. $\mathbb{I}$. Clin. Invest. 66:82-87, 1980.

6. Gralnick HR and Rick ME. Danazol increases factor VIII and factor IX in classical hemophilia and Christmas disease. N. Engl.J. Med. 308: 1393-1395, 1983.

7. Oosterhuis HJGH. Myasthenia grawis. In: Clinical Neurology and Neurosurgery monographs. Glaser GH et all. eds., vol. 5, p. 114, 1984.

8. Zvaifler $N_{n}$ Etiology and pathogenesis of systemic lupus erythematosus. In: Rheumatology. Kelly WW Ed. Saunders, Philadelphia, p. 1085, 1981.

9. Fye KH and Sack KE. Rheumatic disease. In : Basic and Clinical Immunology, Stites DP et al., eds. Lange Medical Publications p. 435-440, 1982.

10. Sackner MA. Scleroderma. New York, Grune and Stratton, 1966.

11. Fye KH and Sack KE. Rheumatic diseases. In: Basic and Clinical Immunology, Stites. DP et al., eds. Lange Medicall Publication, p. 442-444, 1982.

12. Bearn $\mathrm{AG}$, Kunkel $\mathrm{HG}$ and Slater RJ. The problem of liver disease in young women. Am.J. Med. 21: 3-15, 1956.

13. Ahrens EH, Payne MA, Kunkel HG, Eisenmenger WJ and Blandheim SH. Primary biliary cirrhosis. Medicine (Baltimore) 29: 299-364, 1950.

14. Baldini MG. Idiopathic thrombocytopenic purpura and the ITP syndrome. Med. Clin . North Am. 56: $47-64,1972$.

15. Werner SC. In: "The Thyroid. Werner SC and Ingbar SH Eds., Harper and Row, fourth ed., p. 593, 1978 .

16. Korrreich A. Systemic lupus erythematosus in childhood. Clin. Rheumatol. Dis. 2: 249-254, 1976.

17. Lahita RG, Bradlow HL, Fishman J, Kunkel HG. Estrogen metabolism in systemic Iupus erythematosus. Arthritis Rheum. 25: 843-846, 1982.

18. Lahita RG, Bradlow HL, Kunkel HG, Fishman J. Alterations of estrogen metabolism in systemic lupus erythematosus. Arthritis Rheum. 22: 1195-1198, 1979.

19. Melez KA, Boegel WA, Steinberg AD. Therapeutic studies in New Zealand mice VII. Succesfull androgen treatment of NZB/NZW F1, females at different ages. Arthritis Rheum. 23: 41-47, 1980.

20. Verheul HAM, Stimson WH, Den Hollander FC, Schuurs AHWM. The effects of nandrolone, testenore and their decanaote esters on murine lupus, Clin. Exp. Immunol. 44: 11-17, 1981.

21. Dovic $M_{3}$ Steinberg AD, Klassen $L N$. Effect of anti-estrogen, nafoxidine, on $N Z B / W$ autoimmune disease. Arthritis Rheur. 21: 414-417, 1978.

22. Jessell TM, Siegel RE, Fischbach GD. Induction of acetylcholine receptors on cultured skeletal muscle by a factor extracted from brain and spinal cord. Proc. Natl. Acad. Sci. USA 76: 5397-5401, 1979.

23. Markelonis $G J$, On TH. Purification of sciatin using affinity chromatography on concanavalin Aagarose. J. Neurochem. 37: 695-697, 1981.

24. Bauer HC, Daniels MP, Pudimat PA, Jacques L, Sugiyama $H_{3}$ Christian CN. Characterization and partial purification of a neuronal factor which increases acetylcholine receptor aggregation on cultured muscle cells. Brain Res. 209: 395-404, 1981.

25. Birnbaum M, Reis MA, Shainberg A. Role of calcium in the regulation of acetylcholine receptor synthesis in cultured muscle cells. Pflugers Arch. 395: 37-43, 1980. 


\section{SUMMARY}

This thesis originated from a clinical study on autoantibody mediated receptor disease specifically Graves' disease. Since the only experimental model of antibody mediated receptor disease existing at that time - 1978 - was experimental autoimmune myasthenia gravis it was decided to use this model in order to analyze autoantibody receptor interactions.

The questions asked were:

1. Is this a true antibody mediated disease or do immune cells contribute to the lesions?

2. If only antibody causes the disease is there a causal relationship between antibody concentration, antibody specificity and symptoms of disease?

3. Can the auto-antibody receptor interaction be manipulated in a therapeutic usefull way?

\section{Chapter I}

The introductory chapter reviews the literature of clinical autoimmune anti-receptor diseases. Although the mechnisms operational in these diseases may be similar, the clinical spectrum varies from endocrine diseases and neurological disorders to asthma and allergic rhinitis. Conceptually antibodies against cell membrane receptors may bring about disease in three different ways. First, antibodies may bind to the receptor and block ligand induced receptor stimulation. Although myasthenia gravis was originally believed to belong to this category it is now known that blockade of the acetylcholine binding site is not the main cause of disease. Second, antibodies may mimick hormone or neuro-transmittor action and thus stimulate the receptor in the absence of the natural ligand eg. in Graves" disease and some cases of hypoglycaemia; experimental evidence suggest that these stimulating antibodies may be auto-antiidiotypic antibodies. A third mechanism, operative in myasthenia gravis and autoimmune insuline resistance, down regulates receptor molecules yielding reduced numbers of receptors left for stimulation. The spectrum of autoimmune receptor diseases will probably be extended in the near future. Candidate diseases might be hypogammaglobulinemia, and pseudo hypoparathyroidism. For all of the anti-receptor autoimmune diseases only one well characterized animal model exists : experimental autoimmune myasthenia gravis.

\section{Chapter II}

This chapter is a literature study which summarizes the "state of the art" of the experimental autoimmune myasthenia gravis (EAMG) model. Disease is induced by im- 
munizing animals with acetylcholine receptors isolated from the electric organ of fish: Torpedo californica an electric ray residing off the Californian coast or Electrophorus electricus an electric eel found in the Amazone river. Clinically this experimentall model is relevant in terms of pathogenesis of disease (myasthenia gravis) but not in terms of etiology.

Detailed analysis of the acetylcholine receptor by biochemical and immunological means has elucidated the structure of the receptor as well as its antigenic structure. A small part of the acetylcholine receptor residing on the $\alpha$-subunit, the so called main immunogenic region (MIR), is of crucial importance for the development of disease in the experimental animal model and in man.

The electrophysiologic abnormalities observed in the rat model of EAMG - specifically the acute model - are induced by three different immunopathological mechanisms; complement mediated focal lysis, of the neuromuscular membrane increased turnover of acetylcholine receptor (AChR) at the neuromuscular endplate, and possibly by blockade of the acetylcholine binding site. Next to antibodies cellular immune reactions must be important in EAMG although their role is undefined. No clear evidence exists for a role of effector $T$ cells and the role of $T$ helper cells is assumed but not proven in the model of chronic EAMG. The humoral autoimmune reactions observed in EAMG have also been demonstrated in man. Thus EAMG is a usefull model in terms of pathogenesis of myasthenia gravis in man.

\section{Chapter III}

In order to analyze the immune reactions involved in EAMG the first approach was to determine the phenotype and specificity of the cellular immune reactions of rats with chronic EAMG in vitro. For this purpose an in vitro culture system was developed in which sensitized lymphoid cell suspensions from rats with chronic EAMG were cultured in the presence of acetylcholine receptor (AChR) preparations. Next the proliferative cellular responses and anti-AChR antibody secreted was quantitated. The culture system finally adopted required antigen ( $A C h R$ ), sensitized ( $T$ and B) lymphocytes, and antigen presenting cells. The cells that showed a proliferative response to AChR were $T$ cells since they could be lyzed by anti $T$ cell serum in the presence of complement. Their $T$ helper cell nature was suggested by finding that they produced interleukin-2, and by the fact that antibody producing cells required their presence and that the amount of antibody produced in vitro was proportional to the cellular proliferative response. Conclusive evidence derived from an experiment which showed by means of phenotypic separation of $T$ cells with a fluorescence activated cell sorter that the proliferating cells were $T$ helper cells. The $T$ helper cell proliferation had an absolute requirement for accessory cells and the proliferative response was influenced by the physicochemical nature of the AChR added to the culture as illustrated by the finding that $\mathrm{AChR}$ incorporated in lipid membranes (a form reminiscent of the postsynaptic membrane) elicited far greater proliferative $T$ helper cell responses compared to 
solubilized AChR.

Since most of the serum antibodies in EAMG appear to be directed towards the main immunogenic region (MIR) of the AChR the specificity of the T helper cell proliferative response was studied in terms of pathogenetically important specificities : those residing on the MIR and cross reacting with rat AChR. For this pupose Torpedo $A C h R$ was chemically altered by reduction and carboxymethylation (RCM-AChR) or trypsinization ( $t-A C h R$ ). These procedures yielded two differing receptor preparations, RCM-AChR with a selectively destroyed MIR and $t-A C h R$ lacking antigenic determinants outside the MIR. When these chemically altered AChR were added to cultures of immune lymphe-node cells taken from rats with chronic EAMG, a high proliferative $T$ helper cell response and antibody synthesis was observed regardless of the absence or presence of the MIR. These surprising results suggest that in the in vitro culture system the accessory cells first break down the $A C h R$ with a comcommittant partial loss of primary (t-AChR) or tertiary structure (MIR) prior to presentation to the $T$ cells.that here the accessory cells present the tertiairy structure to the $T$ cells.

The cross-reactive specificities were studied by inducing EAMG with Torpedo californica, fetal calf muscle and rat muscle AChR; the sensitized lymph node cells were next cultured in vitro with the three different AChR preparations and the proliferative response as well as the antibody production to each individual $A C h R$ was determined. Rats immunized with Torpedo AChR showed a high degree of cross-reactive $T$ helper cell proliferation to mammalian muscle $A C h R$ whereas rats immunized with muscle $A C h R$ react with muscle AChR (but do not cross-react with Torpedo AChR at the T cell level). The antibody response showed the opposite effects. These findings can only be interpreted to indicate that at the T cell level no tolerance to mammalian AChR exists. They show in addition that cross reactive $T$ cell proliferation and antibody responses to rat $A C h R$ are determined by the species from which the immunogen derives.

\section{Chapter IV}

In this chapter the immunogenicity of differing AChR preparations was related to their in vivo pathogenicity. For these purposes an in vivo model of chronic EAMG was used allowing precise quantitation of the immunopathological lesions at the neuromuscular junction rather than scoring the signs of myasthenia.

First an in vivo model was developed using Torpedo californica $\mathrm{ACh}$ R as immunogen and a dose response curve was made relating the amount of Torpedo californica $A C h \mathbb{R}$ used for immunization to antibody cross reactive with rat AChR in the serum and bound at the site of the neuromuscular junction. Next the immunizing dose of Torpedo $A C h R$ was related to AChR loss and clinical signs of myasthenia. Immunizing doses between $5 \mu \mathrm{g}$ and $15 \mu \mathrm{g}$ caused a dose dependent increase in crossreactive antibody in the serum, immune complex formation at the neuromuscular enplate and AChR loss. AChR loss from the neuromuscular junction was a far better measure of EAMG compared to clinical signs of myasthenia which was only apparent with $A C h R$ losses in ex- 
cess of $70 \%$. In crossreactive antibody excess however - achieved by immunizing rats with dosages of Torpedo californica AChR exceeding $15 \mu \mathrm{g}$ - AChR unoccupied by antibody remained at all demonstrable at the neuromuscular junction which suggested that target organ resistance to antibody mediated receptor loss had occurred. This observation was the basis of the experiments described in Chapter VI.

The specificity of the cross-reactive antibodies causing the AChR loss in vivo was examined next by immunizing rats with reduced and carboxymethylated Torpedo californica $\mathrm{AChR}$ (RCM-AChR). This procedure selectively removes the MIR of AChR as mapped by means of a panel of thirty monoclonal antibodies. Destruction of the MIR did not reduce the immunogenicity of the $A C h R$ in vivo since high titers of anti native AChR antibodies were elicited but abolished pathogenicity as shown by the fact that none of these rats developed myasthenia or AChR loss. In these rats the antibodies crossreactive with rat $A C h R$ were shown to be directed to the cytoplasmic (in vivo non accessible) sittes of the muscle AChR and thus to be irrelevant in terms of pathogenesis of disease. These observations were extended in passive transfer studies using monoclonal antibodies against native and RCM Torpedo AChR. Only antibodies directed to the extracellularly located MIR (present on native but absent from RCMAChR) were capable of causing AChR loss. In contrast to suggestions in the literature preimmunization of rats with RCM-AChR failed to protect against native Torpedo AChR induced EAMG nor was an ongoing EAMG cured by immunizations with RCM-AChR. These observations are compatible with the view that in terms of immunogenicity RCM-AChR is the equivalent of the carrier and that the MIR functions as hapten. The cross-reactive immune response to the hapten determines antibody specificity and thus pathogenicity. In order to demonstrate that this cross-reactive immune response was mediated by antibody only passive transfer studies were performed using in vitro expanded immune cells isolated from lymph nodes of rats with EAMG. In vitro expansion of immune $\mathrm{T}$ cells with a $\mathrm{T}$ cell mitogen (in a manner identical to that used for passive transfer of effector $T$ cells in experimental allergic encephalitis) failed to induce AChR loss in the recipient. Passive transfer was only successful when the immune cells were expanded in vitro in the presence of AChR; the receptor loss observed was mediated by actively secreted and cross-reactive antibody. The autoantibody levels in the serum of the recipients of passively transferred cells decreased rapidly suggesting that the autologous $A C h R$ is not capable of expanding these primed $\mathrm{T}$ (helper) cells possibly because the membrane antigens residing on the receptor do not circulate in the extra cellular fluid. The studies described in this chapter therefore support the view that chronic EAMG is an antibody mediated disease requiring the continual presence of immunogen and primed helper $T$ cells.

\section{Chapter V}

In chapter $\mathrm{V}$ the anti-AChR antibodies that mediate the $\mathrm{AChR}$ loss from muscle in rats with chronic EAMG were examined in terms of specificity and spectrotype (isoelectric 
point) in order to rule out that restricted specificities (e.g. the products of limited number of B cell clones not readily apparent in serum) contributed to the disease. This possibility had to be investigated because in conditions of considerable excess of antibody to the MIR in the serum of rats immunized with large doses of Torpedo AChR unoccupied $A C h R$ (capable of binding antibody) was at all times demonstrable at the neuromuscular junction of rats with chronic EAMG. Apart from target organ resistance (e.g. increased synthesis of $\mathrm{AChR}$ ) this observation could also be due to a restriction of antibodies bound to the muscle AChR, when compared to the antibodies present in the serum. Differences in charge of anti-AChR antibody molecules could allow the more positively charged antibody to bind to the interstitial matrix consisting of mucopolyssacharides carrying a negative charge at $\mathrm{pH} 7.4$. Alternatively the antibody response itself might be restricted and thus low concentrations of antibody of a certain specificity might be concentrated at the neuromuscular junction and thus escape detection when measuring the antibody specificities in the serum. We first determined whether antibodies directed to the acetylcholine binding site contributed - in addition to those directed to the MIR - to the disease. Using a solid phase assay system almost no antibody to the acetylcholine binding site was demonstrable in EAMG suggesting that results of others using precipitation assays might be artifacts. Differences in charge (isoelectric point) of anti-AChR antibody molecules from the serum and in immune complexes from the neuromuscular junction were analyzed by reversed isoeletric focusing followed by radiolabeled AChR overlay. This technique allows analysis of the antibody response in terms of variable chain diversity and is capable of detecting low concentrations of a limited number of $\mathbf{B}$ cell clone products. The procedure dissociates antigen-antibody complexes and thus allows spectrotypic analysis of antibody residing in these complexes. Sequential studies on sera from rats with chronic EAMG showed the full spectrotype to be expressed early after immunization and not to change with the onset of disease suggesting that the spectrotype of anti Torpedo AChR antibodies does not influence disease. This was confirmed by finding the spectrotype of anti-rat muscle AChR antibodies eluted from the neuromuscular junction to be identical with those of the serum. These results show the antibody response in chronic EAMG to be polyclonal; also in myasthenia is brought about by a polyclonal antibody response which is directed towards the MIR. The observation that unoccupied AChR receptor is demonstrable in condition of apparent crossreactive antibody excess suggests that target organ characteristics in addition to cross reactive antibody determines AChR loss.

\section{Chapter VI}

In chapter VI the effect of target organ manipulation on EAMG was studied; the results obtained were the basis for designing a new strategy for the treatment of myasthenia.

Since the muscle is capable of large increases in AChR synthesis during embryonal 
development and after denervation the hypothesis was advanced that secondary to an immunological attack resulting in a cross-linking of $A C h R$ at the neuromuscular junction a reactive increase in $A C h R$ occurs. If this were so not only suppression of the antibody response by aspecific or specific means but also enhancement of the AChR synthesis would be expected to have beneficial effects in EAMG.

In order to test this hypothesis rats were given a unilateral limb denervation by removal of the ischiadic nerve and 8 days later monoclonal antibody directed towards the MIR was infused. The denervated limb contained 4 times as much AChR compared to the control leg and more importantly showed no AChR loss in contrast to the control leg. This experiment suggested that antibody mediated AChR loss in the denervated leg was compensated for by enhanced AChR synthesis. Next the effect of unilateral limb denervation performed at the time of induction of chronic EAMG, was studied. All rats had high titers of anti-AChR antibody but the amount of AChR loss form the control leg was 4 times that of the denervated leg; the percentage of AChR complexed with antibody in the denervated leg $(17 \%)$ however was far less than the control leg $(27 \%)$. This lower AChR occupancy with antibody in the denervated leg agrees with the view that in this leg a greater reactive increase in $\mathrm{AChR}$ synthesis had occurred compared to the normal leg.

The effect of anabolic steroids (nandrolone) on chronic EAMG was examined next for two reasons. First anabolic steroids have a clearcut positive effect on muscle mass and androgens enhance the synthesis of deficient proteins in some hereditary human diseases. Thus we hypothetized that anabolic steroids might also influence the reactive increase in AChR synthesis after antibody mediated AChR cross linking in analogy to the experiments with denervation. In addition, epidemiological evidence in man and experimental evidence from spontaneous animal models show sex hormones to play a role in autoimmune diseases inclusive myasthenia gravis.

Female Lewis rats were immunized with Torpedo $A C h R$ and a dose of anabolic steroids were given every two weeks; animals were sacrificed 30 days after the first immunization with $\mathrm{AChR}$. At this time 3 out of 4 control rats showed severe myasthenia clinically whereas none of the treated rats were myasthenic. In the control rats the clinical myasthenia was associated with a $53 \%$ muscle AChR receptor loss; of the remaining $80 \% \mathrm{AChR}$ was complexed with antibody. Compared to the controls the rats treated with anabolic steroids showed significantly less cross reactive antibody in the serum. Striking were the differences in immune complex formation at the neuromuscular junction: the rats treated with anabolic sterolds showed somewhat less muscle AChR loss (43\%) compared to controls (53\%) but of the remaining AChR only $44 \%$ was complexed to antibody. These results show anabolic steroids to be beneficial in rats with chronic EAMG because of decreasing antibody concentration; in addition however a beneficial effect on the increase in AChR synthesis induced by antibody mediated AChR cross linking appears likely. 


\section{SAMENVATTING}

Dit proefschrift is tot stand gekomen naar aanleiding van klinische vraagstellingen op het gebied van onderzoek naar ziekten welke veroorzaakt worden door auto-antilichamen gericht tegen receptoren, in het bijzonder zoals bij de ziekte van Graves. Omdat in 1978 alleen experimentele autoimmuun myasthenia gravis bekend was als model voor een dergelijke ziekte (welke dus veroorzaakt wordt door antilichamen gericht tegen receptoren) werd besloten dit model te gebruiken om interacties tussen auto-antilichamen en receptoren te analyseren. Daartoe werden de volgende vraagstellingen geformulleerd:

1. Wordt deze ziekte uitsluitend door antilichamen veroorzaakt of dragen immunologisch actieve cellen ook bij tot de weefselbeschadiging?

2. Indien auto-antilichamen de enige veroorzakers van de ziekte zijn, bestaat er dan een causaal verband tussen de hoeveelheid geproduceerde antilichamen, hun specificiteit en de ernst van de symptomen van de ziekte?

3. Kan op een therapeutisch relevante wijze geinvenieerd worden in de interactie tussen autoantilichaam en receptor?

\section{Hoofdstuk I}

Dit inleidende hoofdstuk geeft een overzicht over de literatuur van de kliniek van autoimmuunziekten tegen receptoren. Hoewel de mechanismen die bij deze ziekten betrokken zijn veel gemeen kunnen hebben, beslaan deze ziekten een breed klinische spectrum dat loopt van endocriene ziekten en neurologische afwijkingen tot asthma en allergische rhinitis. Er zijn drie manieren waarop antilichamen tegen receptoren in de celmembraan ziekte kunnen veroorzaken. Ten eerste: antilichamen kunnen zich aan de receptor binden en (daardoor) stimulatie van de receptor door het ligand verhinderen. Hoewel men oorspronkelijk meende dat myasthenia gravis tot deze categorie behoorde wordt nu gesuggereerd dat blokkade van de bindingsplaats voor acetylcholine niet de belangrijkste oorzaak van de ziekte is. Ten tweede: antilichamen kunnen de werking van een hormoon of neurotransmitter imiteren en zodoende de receptor stimuleren in afwezigheid van het natuurlijke ligand! Dit is bijvoorbeeld het geval bij de ziekte van Graves en in sommige gevallen van hypoglycaemie; resultaten uit experimenten geven aan dat deze "stimulerende" antilichamen in feite anti-idiotypische auto-antilichamen zouden kunnen zijn. Het derde mechanisme dat werkzaam is in myasthenia gravis en in een door auto-immuniteit veroorzaakte vorm van insuline-resistentie heeft een negatief effect op de aanmaak van receptor moleculen zodat minder receptoren beschikbaar zijn voor stimulatie. Waarschijnlijk zal het scala van door auto-immuniteit veroorzaakte ziekten waarbij receptoren betrokken zijn in de nabije toekomst nog worden uitgebreid. Als kandidaten voor deze uitbreiding kunnen hypogammaglobulinaemie en 
pseudo-hypoparathyreoidie worden genoemd. Voor al deze zogenaamde "antireceptor auto-immuunziekten" bestaat maar een goed uitgewerkt proefdiermodel: experimentele auto-immuun myasthenia gravis (EAMG).

\section{Hoofdstuk II}

Dit hoofdstuk is gebaseerd op literatuur-onderzoek; het vat de meest recente bevindingen in het EAMG-model samen. De ziekte wordt opgewekt door proefdieren te immunizeren met acetylcholine-receptoren welke geisoleerd worden uit het electrische orgaan van een sidder-rog (Torpedo californica) welke voor de Californische kust leeft, of van een sidder-aal (Electrophorus electricus) welke in de Amazonerivier voorkomt.

Dit proefdiermodel is klinisch relevant voor zover het de pathogenese van myasthenia gravis betreft, maar niet voor het bestuderen van de etiologie. Nauwgezet biochemisch en immunologisch onderzoek van de acetylcholine receptor heeft zowel de biochemische als de antigene structuur van de receptor aan het licht gebracht. Op een beperkt gedeelte van de receptor (de $\alpha$-subunit) bevindt zich zowel de bindingsplaats voor acethylcholine als de plaats waar antilichamen worden gebonden. Dit laatste gebied, het zogenaamde dominante immunogene gebied ("main immunogenic region": MIR) is van cruciaal belang voor de ontwikkeling van de ziekte, zowel in het proefdiermodel als in de mens.

De electro-fysiologische afwijkingen welke met name in het acute rattemodel voor EAMG worden gevonden, worden door drie verschillende immunopathologisch mechanismen veroorzaakt, te weten door complement teweeg gebrachte focale lysis van de receptor, versnelde afbraak en aanmaak van acetylcholine receptoren ( $A C h R$ ) in de zenuw-eindplaatjes op de spier en mogelijk door blokkade van de bindingsplaats voor acetylcholine. Naast antilichamen kunnen ook cellulaire immuunreakties van belang zijn in EAMG hoewel hun rol nog niet precies bekend is. Er is geen onweerlegbaar bewijs voor een rol van effector $T$ cellen terwijl van helper $T$ cellen alleen maar wordt aangenomen dat ze een rol spelen in het chronische EAMG model. De humorale autoimmuun reakties welke in EAMG zijn gevonden zijn ook bij de mens aangetoond. Vandaar dat EAMG een bruikbaar model is voor de pathogenese van myasthenia gravis in de mens.

\section{Hoofdstuk III}

Voor het analyseren van de immuunreaktie die deel uitmaakt van het chronische EAMG model is in eerste instantie het fenotype en de specificiteit van de cellulaire immuunreakties in vitro bepaald. Hiertoe werd een in vitro kweeksysteem ontwikkeld waarin suspensies van (gesensitizeerde) lymfoide cellen, verkregen uit ratten met chronische EAMG, gekweekt werden in aanwezigheid van AChR. Vervolgens werd de proliferatieve respons van de cellen gemeten en de geproduceerde hoeveelheid anti-AChR antilichamen gekwantiteerd. Het uiteindelijke door ons gebruikte kweeksysteem bleek 
afhankelijk te zijn van de simultane aanwezigheid van antigeen (AChR), gesensitizeerde ( $T$ en B) lymfocyten en antigeen-presenterende cellen. De cellen die in respons op $A C h R$ prolifereerden, bleken $T$ cellen te zijn; het was mogelijk ze te lyseren met behulp van een anti-T cel serum en complement. Dat het hier om helper $T$ cellen ging, werd aannemelijk door de bevinding dat deze cellen interleukine-2 produceerden en door het feit, dat de antilichaamproducerende cellen van hun aanwezigheid afhankelijk waren. Bovendien correleerde de hoeveelheid geproduceerde antilichamen positief met de proliferatieve respons van de $\mathbb{T}$ cellen. Het doorslaggevende bewijs werd geleverd in een experiment waarin met behulp van een "Fluorescence-Activated Cell sorter" $T$ cellen op basis van hun fenotype werden gescheiden, waarna bleek dat de helper $T$ cellen de prolifererende cellen waren. Proliferatie van de helper $T$ cellen was volstrekt afhankelijk van de aanwezigheid van antigeen-presenterende cellen; bovendien werd de proliferatieve respons beinvloed door de fysico-chemische vorm waarin de AChR aan de celkweek werd toegevoegd. Dit laatste punt werd geillustreerd door de bevinding, dat de AChR ingebouwd in lipide-membranen (een vorm die doet denken aan de post-synaptische membraan) een sterkere proliferatieve T cel respons opwekte dan AChR in opgeloste vorm. Aangezien de meeste antilichamen in EAMG tegen de MIR van de AChR gericht zijn, werd de specificiteit van de proliferatieve helper $T$ cel respons met name onderzocht op pathogenetisch belangrijke specificiteiten: die tegen MIR en die welke kruisreactiviteit vertonen tegen de ratten-AChR. Hiertoe werd Torpedo AChR chemisch veranderd door middel van reductie en carboxylatie (RCM-AChR) of door middel van trypsinisatie (t-AChR). Deze procedures leverden twee verschillende receptorpreparaten op: RCM-AChR met een selectief vernietigd MIR en t-AChR zonder antigene determinanten buiten de MIR. Als deze chemisch gemodificeerde AChR werden toegevoegd aan kweken van lymfekliercellen uit ratten met chronische EAMG (opgewekt met natief Torpedo $\mathrm{AChR}$ ) werd een flinke proliferatieve respons van helper $\mathrm{T}$ cellen alsmede antilichaamproduktie waargenomen, zulks onafhankelijk van de aan- of afwezigheid van de MIR. Dit verrassende resultaat doet vermoeden dat de antigeenpresenterende cellen in het in vitro kweeksysteem eerst de $A C h R$ afbreken, waarbij dan de primaire (zoals bij t-AChR) of tertiaire structuur (zoals van MIR) gedeeltelijk verloren gaat, om vervolgens het afgebroken antigeen aan te bieden aan de $\mathrm{T}$ cellen.

De kruis-reagerende specificiteiten werden bestudeerd door EAMG op te wekken met AChR uit Torpedo californica, uit spieren van runderfoetussen of uit rattespieren. Vervolgens werden de daardoor gesensitizeerde cellen uit de lymfeklieren in vitro gekweekt met de drie verschillende AChR-preparaten en werden de proliferatieve respons en antilichaamprodukties tegen elk der AChR preparaten bepaald. Ratten welke met Torpedo $A C h R$ waren geimmuniseerd lieten een hoge mate van helper $T$ cel kruis-reactiviteit zien in hun proliferatieve respons tegen $\mathrm{AChR}$ uit spieren van zoogdieren, terwijl ratten geimmuniseerd met spier-AChR wel tegen spier-AChR reageerden maar geen kruisreactiviteit op het niveau van de $T$ cel tegen Torpedo $A C h R$ vertoonden. De antilichaamrespons liet echter het tegenovergestelde zien. Deze bevindingen leidden tot de enig mogelijke interpretatie dat er op het niveau van de $T$ cel geen tolerantie tegen 
AChR uit zoogdierweefsel bestaat. Bovendien blijkt hieruit dat de kruis-reactiviteit van $T$ cel proliferatie en van antilichamen tegen de $A C h R$ van de rat bepaald wordt door de diersoort waaruit het immunogeen wordt geisoleerd.

\section{Hoofdstuk IV}

Allereerst werd door ons in dit deel van het onderzoek de immunogeniciteit van verschillende AChR-preparaten onderzocht in relatie tot hun pathogeniciteit in vivo. Hiertoe werd een in vivo model voor chronische EAMG gebruikt waarin, eerder dan af te gaan op het registreren van de symptomen van klinisch manifeste myasthenie de immunopathologische beschadigingen van de neuro-musculaire eindplaat exact gekwantiteerd kunnen worden.

Gebruik makend van Torpedo AChR als immunogeen werd allereerst het in vivo model ontwikkeld. Voor dit model werd in een dosis-respons curve de relatie tussen de voor de immunisatie gebruikte hoeveelheid Torpedo AChR en de opgewekte (met rat AChR kruis-reagerende ) vrije antilichamen in het serum, plus die welke gebonden waren in de neuromusculaire eindplaat, vastgelegd. Zodoende kon vervolgens de dosis Torpedo AChR gebruikt voor de immunisatie gerelateerd worden aan het verlies aan AChR en de klinische verschijnselen van myasthenie. Doses varierend van 5 tot $15 \mu \mathrm{g}$ Torpedo $A C h R$ veroorzaakten zowel een dosis-afhankelijke toename van kruis-reactieve antilichamen in het serum, de vorming van immuuncomplexen in de neuro-musculaire eindplaat als een verlies van AChR. Verlies van AChR in de neuro-musculaire eindplaat bleek een betere maat voor EAMG te zijn dan registratie van de klinische verschijnselen van myasthenie welke pas manifest werden wanneer meer dan $70 \%$ van de AChR verloren waren gegaan. In aanwezigheid van een overmaat kruis-reagerende antilichamen (bereikt door ratten te immuniseren met hoeveelheden Torpedo AChR boven de $15 \mu \mathrm{g}$ ) bleven echter in de neuromusculaire eindplaat nog steeds receptoren aantoonbaar die niet bezet waren door anti-AChR antilichamen; dit zou er op kunnen wijzen dat zich in de eindplaat resistentie tegen het door antilichamen veroorzaakte verlies van receptoren had ontwikkeld. Deze waarneming ligt ten grondslag aan de proeven welke in Hoofdstuk VI beschreven zijn.

Vervolgens werd de specificiteit van de kruis-reagerende antilichamen, die het verlies van $\mathrm{AChR}$ in wivo veroorzaken, nagegaan door ratten te immunizeren met (chemisch gemodificeerde) RCM-AChR. Zoals door gebruik van een aantal monoclonale antillichamen tegen AChR kon worden aangetoond is op deze RCM-AChR geen MIR meer aanwezig terwijl de antigene determinanten buiten de MIR niet aangetast worden. Vernietiging van de MIR verminderde de in vivo immunogeniciteit van de $A C h R$ niet aangezien er hoge titers anti-AChR antilichamen mee konden worden opgewekt; wel bleek dit immunogeen niet pathogeen meer te zijn want geen van deze ratten ontwikkelde myasthenie of verloor $\mathrm{AChR}$. De met ratte-AChR kruis-reagerende antilichamen bleken in deze ratten tegen intracellulair gelegen plaatsen van de spier-AChR gericht te zijn. Deze plaatsen zijn in vivo onbereikbaar en de ertegen gerichte antilichamen zijn derhal- 
ve irrelewant voor het ontstaan van de ziekte. Deze waarnemingen werden nog verder uitgebreid in experimenten waarin monoclonale antlichamen tegen natief $A C h R$ en RCM-AChR uit Torpedo "passief" werden toegediend aan ratten. Uitsluitend antilichamen gericht tegen de extracellulair gelegen MIR - aanwezig op de natieve, maar niet op RCM-AChR - veroorzaken verlies van AChR. In tegenstelling tot aanwijzingen in de literatuur bleek immunizatie van ratten met $\mathbb{R C M}-A C h R$ geen bescherming te bieden tegen inductie van EAMG met natieve Torpedo $\mathrm{AChR}_{\text {; }}$ ook een bestaande EAMG werd niet genezen door immunizatie met RCM-AChR. Deze waarnemingen zijn verenigbaar met de hypothese dat RCM-AChR qua immunogeniciteit als de zgn. "carrier" kan worden gezien en dat de MIR als hapteen fungeert. De kruis-reactiviteit van de immuunrespons tegen het hapteen bepaalt dus de specificiteit van de antilichamen en daarmee dus de pathogeniciteit. Om te bewijzen dat deze kruis-reactieve immuunrespons uitsluitend door antilichamen tot stand wordt gebracht, werden studies verricht waarin gesensitizeerde cellen uit de lymfeklieren van dieren met EAMG na vermenigvuldiging in vitro passief werden doorgegeven aan onbehandelde ratten. Indien de gesensitizeerde $T$ cellen in vitro met behulp van een $T$ cel mitogeen werden vermenigvuldigd (zoals ook elders werd toegepast voor de passieve overdracht van experimentele allergische encephalitis met behulp van effector $\mathrm{T}$ cellen) werd geen antlichaamrespons tegen $A C h R$ in de ontvanger gevonden. Dergelijke passieve overdracht had alleen succes indien de gesensitizeerde cellen in vitro werden gekweekt in de aanwezigheid van $\mathrm{AChR}$; het gevonden verlies aan AChR in deze ontvangers werd veroorzaakt door de actief geproduceerde kruis-reactieve antilichamen. De spiegels van auto-antilichamen in het serum van de ontvangers van passief doorgegeven cellen nam snel af, wat erop wijst dat autologe AChR niet in staat was deze gesensitizeerde (helper) $T$ cellen in vivo te laten delen. Dit kan het gevolg zijn van het feit dat receptor-geassocieerde membraanantigenen niet vrij in de extra-cellulaire vloeistof voorkomen. De in dit hoofdstuk beschreven onderzoekingen ondersteunen dus de idee dat chronische EAMG een ziekte is die veroorzaakt wordt door antilichamen. De aanmaak hiervan is afhankelijk van de ononderbroken aanwezigheid van immunogeen en specifiek geactiveerde helper $\mathrm{T}$ cellen.

\section{Hoofdstuk V}

In het onderzoek beschreven in Hoofdstuk V werden de anti-AChR antilichamen die tot verlies van spier-AChR in ratten met chronische EAMG aanleiding geven nader onderzocht op specificiteit en op iso-electrisch punt. Dit onderzoek werd verricht om uit te sluiten dat juist antilichamen met een beperkt aantal specificiteiten (bijvoorbeeld omdat zij zijn voortgekomen uit een beperkt aantal B cel clonen en dus niet zijn aan te tonen in het serum) bijdragen tot het ontstaan van de ziekte. Deze mogelijkheid diende te worden onderzocht omdat van ratten, die geimmuniseerd waren met grote doses Torpedo AChR ondanks een aanzienlijke overmaat antilichamen in het serum tegen de MIR toch steeds vrije AChR in de neuro-musculaire eindplaat konden worden aange- 
toond (AChR die nog steeds in staat waren antilichamen te binden). Afgezien van opbouw van resistentie (bijvoorbeeld door versnelde synthese van $A C h R$ ) zou deze observatie ook het gevolg kunnen zijn van een beperkte mogelijkheid van antilichamen om zich aan de spier-AChR te binden.

Ladingsverschillen tussen anti-AChR antilichaam moleculen zou de meer positief geladen antilichamen in staat stellen de interstitiele matrix te passeren welke bestaat uit mucopolysacchariden welke bij pH 7.4 negatief geladen zijn. Een andere mogelijkheid is, dat de antilichaamrespons van (zeer) beperkte specificiteit zou kunnen zijn en dat een (absoluut gezien) geringe hoeveelheid antilichamen met een bepaalde specificiteit geconcentreerd wordt in de neuro-musculaire eindplaat, zodat ze niet kunnen worden aangetoond in het serum. Eerst werd door ons nagegaan of antilichamen gericht tegen de bindingsplaats voor acetylcholine, alsook die welke tegen de MIR gericht zijn, bijdragen tot het ontstaan van ziekte. Met gebruikmaking van een "solid phase" testsysteem waren in EAMG echter vrijwel geen antilichamen tegen de acetylcholine-bindingsplaatsen aantoonbaar, wat doet veronderstellen dat de resultaten van anderen die gebruik maakten van precipitatietestsystemen op artefacten zouden kunnen berusten. Ladingsverschillen (ofwel verschillen in iso-electrisch punt) tussen anti-AChR antilichamen uit het serum en uit immuuncomplexen geisoleerd van de neuromusculaire eindplaat werden nagegaan door omgekeerde iso-electrische focussering gevolgd door incubatie met radioactief-gemerkt $A C h R$. Deze techniek maakt het mogelijk de diversiteit van de antilichaamrespons te analyzeren; lage concentraties van produkten van een beperkt aantal $\mathrm{B}$ cel clonen kunnen er mee worden opgespoord. Bij het toepassen van deze procedure vallen antigeen-antilichaam-complexen uit elkaar zodat het mogelijk wordt het spectrotype (isoelectrische punten) van de antilichamen uit deze complexen te bepalen. Met tussenpozen herhaalde bepalingen op serummonsters van ratten met chronische EAMG lieten in de tijd steeds een constante expressie van alle spectrotypen zien. Dit was reeds het geval vroeg na de immunisatie en het veranderde niet bij het manifest worden van de ziekte wat erop wijst dat het spectrotype van de anti-Torpedo AChR antilichamen geen invloed heeft op het verloop van de ziekte. Dit werd eens te meer bevestigd door de constatering dat het spectrotype van antilichamen gericht tegen rattespier-AChR geëlueerd van immuuncomplexen uit de neuro-musculaire eindplaat identiek was aan die van het serum. Deze resultaten tonen aan dat de antilichaamrespons in chronische EAMG polyclonaal is; ook in de mens wordt myasthenie veroorzaakt door een polyclonale antilichaamrespons die tegen de MIR gericht is. De bevinding dat onder omstandigheden waarbij kennelijk een overmaat kruis-reactivieve antilichamen aanwezig is toch onbezette $\mathrm{ACh}$ aantoonbaar zijn wijst erop dat behalve eigenschappen van de kruis-reactieve antilichamen ook die van de eindplaat van belang zijn.

\section{Hoofdstuk VI}

In Hoofdstuk VI wordt het effect van manipulatie van het doelwit van de immuun- 
respons in EAMG beschreven; de in deze studie verkregen resultaten hebben als uitgangspunt gediend voor het ontwerpen van een nieuwe strategie voor de behandeling van myasthenia.

Aangezien de spier zowel gedurende de embryonale ontwikkeling als na denervatie in staat is tot een grote toename in de aanmaak van AChR werd de hypothese gelanceerd dat ook na een aanval door immunologische effectormechanismen (resulterend in het ontstaan van onderlinge koppeling tussen AChR in de neuro-musculaire eindplaat) "cross-linking" als reactief proces zal toenemen. Mocht dat zo zijn dan zou dus niet alleen specifieke of a-specifieke onderdrukking van de antilichaamrespons een gunstig effect op het verloop van EAMG hebben, maar ook behandelingen welke de synthese van $A C h R$ versnellen.

Deze hypothese werd getoetst door bij ratten een achterpoot te denerveren door de nervus ischiaticus te verwijderen; 8 dagen later werden deze ratten ingespoten met monoclonale antilichamen tegen de MIR. In de gedenerveerde poot werd 4 maal zo veel $A C h R$ gevonden vergeleken met de niet-gedenerveerde controle poot. Nog belangrijker was de bevinding dat, in tegenstelling tot in de controle poot, in de gedenerveerde poot geen verlies aan $A C h R$ was opgetreden. De resultaten van dit experiment suggereerden dat het door de antilichamen veroorzaakte verlies van AChR in de gedenerveerde poot werd goedgemaakt door de reactieve toename van de $A C h R$ synthese. Vervolgens werd het effect van denervatie uitgevoerd op het moment van de inductie van chronische EAMG, op het verlies aan spier AChR gemeten. Alle ratten ontwikkelden hoge antiAChR antilichaam titers maar in de controle poten werd procentueel 4 maal zoveel verlies aan AChR gemeten als in de gedenerveerde poten. In de gedenerveerde poten was het percentage antilichaam dat gebonden was aan de AChR echter lager (27\%). Deze lagere bezettingsgraad van AChR door antilichamen in de gedenerveerde poten steunt de visie dat in deze poten een sterkere reactieve toename van de AchR synthese had plaatsgevonden dan in de controle poten. Vervolgens werd om twee redenen het effect van anabole steroiden (nandrolone) op chronische EAMG nagegaan. Ten eerste, omdat anabole steroiden een duidelijk positief effect op de spiermassa hebben en omdat androgenen de synthese van ontbrekende eiwitten bevorderen in bepaalde erfelijke ziekten bij de mens. We veronderstelden dat anabole steroiden, naar analogie van denervatie-experimenten, ook de reactieve toename van de $A C h R$ synthese na de door antilichamen tot stand gebrachte cross-linking van individuele $A C h R$ zouden kunnen beinvloeden. Bovendien is er epidemiologisch bewijsmateriaal betreffende de mens, als experimenteel bewijs uit spontane proefdier modellen, dat geslachtshormonen een rol spelen in auto-immuunziekten, met inbegrip van myasthenia gravis. Vrouwelijke Lewis ratten werden geimmuniseerd met Torpedo $\mathrm{AChR}$ en kregen om de twee weken een dosis anabole steroiden. Deze dieren werden 30 dagen na de eerste immunisatie met $A C h R$ afgemaakt; 3 van de 4 ratten vertoonde toen klinisch gesproken ernstige myasthenie. In de controle ratten werd met de klinische myasthenie $50 \%$ verlies van de spier-AChR gezien; $80 \%$ van de resterende AChR was echter bezet door antilichamen. In vergelijking met de controles werden in het serum van de met anabole steroiden behandelde 
ratten statistisch significant minder kruis-reagerende antilichamen gevonden. De verschillen in de mate van immuuncomplexvorming in de neuro-musculaire eindplaat waren echter het meest in het oog springend: hoewel de met anabole steroiden behandelde ratten iets minder spier- $\mathrm{AChR}$ hadden verloren dan de controles ( $43 \%$ vs. $53 \%$ ) was in deze dieren van de overgebleven AChR slechts $44 \%$ bezet door antilichamen. Deze resultaten tonen aan dat annabole steroiden in ratten een gusntig effect hebben op chronische EAMG omdat ze de concentratie van de antilichamen verlagen; daarnaast lijkt het waarschijnlijk dat er tevens een gunstig effect is op de toename van de AChR synthese in reactie op de door antilichamen tot stand gebrachte verbinding van individuele AChR. 


\section{ADDENDUM: Material and methods}

\section{ANIMALS}

Inbred female Lewis and Brown-Norway rats were obtained from Charles River laboratories (Wilmington, MA) or from our own breeding colony (Dept. of Experimental Animal Services of the University of Limburg, Maastricht, The Netherlands). The rats were bred under special pathogen free circumstances. All animals were supplied with normal tap water and rat chow ad libitum. Rats purchased from both suppliers did not differ in their in vivo or in vitro reactivity to $\mathrm{AChR}$. Torpedo californica electric ray and electro-phorus electricus (ellectric cel) was obtained from Pacific Biomarine (Venice, California U.S.). The main electric organ was removed and frozen on dry ice and kept at $-70^{\circ} \mathrm{C}$.

\section{ACETYLCHOLINE RECEPTOR PREPARATION}

\subsection{Soluble AChR}

AChR solubilized with Triton X-100 from the main electric organ of Torpedo californica or Electrophorus electricus, fetal bovine muscle or denervated rat muscles was purified on an affinity column of Naja Naja Siamensis (Miami Serpentarium, Florida, USA) coupled to sepharose CL4B, followed by specific elution with an acetylcholine analogue benzoquinonium (gift of Stirling Winthrop). In order to avoid proteolysis, EDTA, iodoacetamide and phenylmethanesulfonylfluoride (PMSF sigma) were used as protease inhibitors. The entire procedure was performed at $4^{\circ} \mathrm{C}$ in a cold room and completed within $24 \mathrm{hr}$.

A typical procedure as carried out in Dr. J.M. Lindstrom's laboratory is as follows (1): Typically $400 \mathrm{gr}$ frozen Torpedo californica electric organ was broken into chuncks and mixed with 1.5 volumes of $10 \mathrm{mM}$ Na phosphate pH $7.5,10 \mathrm{mM} \mathrm{NaN3}, 5 \mathrm{mM}$ EDTA, and agitated occasionally over about $15 \mathrm{~min}$ while the tissue thawed.

Iodoacetamide (to $5 \mathrm{mM}$ ) and PMSF (to $1 \mathrm{mM}$ ) were added and the mixture was homogenized in a 1-gallon Warring blendor for $8 \times 15 \mathrm{sec}$ at high speed. The initial homogenate was then centrifuged at low speed, 10 min., at 5000 rpm in a Beckman JA-14 rotor. The supernatant was strained through a wire mesh to remove large fragments. The pellet was rehomogenized $1 \times 30$ seconds in an equal volume of the inital buffer, recentrifuged, and the strained supernatant poolled with the first. The low speed pellet was discarded and the supernatant was centrifuged in a Beckman type JA-20 rotor at 19000 rpm for $60 \mathrm{~min}$. This crude membrane pellet was resuspended with a Virtis homogenizer in $10 \mathrm{mM}$ Na phosphate buffer pH 7.5, $10 \mathrm{mM} \mathrm{NaN}_{3}, 1 \mathrm{mM}$ EDTA. Sodium cholate $\left(10 \%\right.$ in $\left.\mathrm{dH}_{2} \mathrm{O}\right)$ was added to the suspension to a final concentration of $2 \%$. After 
30 min. shaking at $4^{\circ} \mathrm{C}$, the mixture was centrifuged for $30 \mathrm{~min}$ at $30.000 \mathrm{rpm}$ in a Beckman no. 30 rotor. The supernatant was added to toxin-sepharose $(0,5 \mathrm{mg}$ of $\mathrm{Naja}$ Naja Siamensis toxin $11 / \mathrm{ml}$ of sepharose CL4B)at about $5 \mathrm{nmol}( \pm 0,6 \mathrm{mg})$ of $\mathrm{AChR} / \mathrm{ml}$ of toxin-sepharose and shaken gently for $1 \mathrm{~h}$ before being poured into a column. The colum was washed with 300 column-volumes of $0.2 \%$ cholate buffer $(.2 \%$ Na Cholate, $100 \mathrm{mM} \mathrm{NaCl}, 4 \mathrm{mM} \mathrm{Na}$ Phosphate, pH 7.5). AChR was eluted with 2 $\mathrm{mM}$ Benzoquinonium chloride in $0.2 \%$ cholate buffer overnight into a small DEAE cellulose $(40 \mathrm{ml})$ column in a pumped closed system at $4^{\circ} \mathrm{C}$. The DEAE column was washed with one column of $0.2 \%$ cholate buffer, then eluted with $0.5 \mathrm{M} \mathrm{NaCl} 0,2 \%$ cholate buffer. Torpedo AChR had a specific activity of about $10 \mathrm{nmol} \alpha$-bungarotoxin binding sites $/ \mathrm{mg}$ protein.

\subsection{Subunits}

The four subunits composing Torpedo AChR were purified by preparative electrophoresis in sodiumdodecylsulfate (SDS) (2). The AChR preparation was concentrated in an Amicon XM 100 apparatus in $0.2 \%$ cholate buffer plus $0.5 \mathrm{M} \mathrm{NaCl}$ to $5 \mathrm{ml}$. After addi-

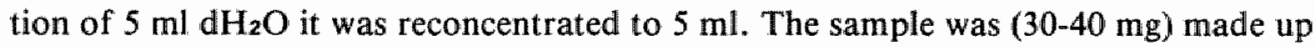
to $14 \mathrm{ml}$ with sample buffer $(2.3 \%$ SDS, $5 \%$ mercaptoethanol, $10 \%$ glycerol and 62,5 $\mathrm{mM}$ TRIS-HCl $\mathrm{pH} 6.8)$ and applied to a preparative gel of $10 \%$ acrylamide containing $0.1 \%$ SDS $(0,5 \times 34 \times 27 \mathrm{~cm})$ with a stacking gel of $4,75 \%$ acrylamide $(0,5 \times 5 \times 27 \mathrm{~cm})$. The gel was run at $125 \mathrm{~mA}$ at $4^{\circ} \mathrm{C}$ for 16 hrs. The gel was stained with $0,25 \%$ Coomassie Brilliant Blue in $50 \%$ methanol and $0,5 \%$ acetic acid for 2 minutes and destained minimally with $50 \%$ methanol and $0,5 \%$ acetic acid. The gel was then sliced and the indivi-

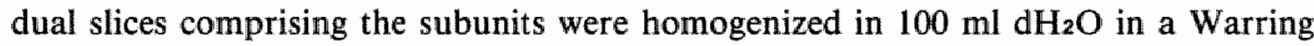
blendor (155). Then $200 \mathrm{ml} \mathrm{dH20} \mathrm{is} \mathrm{added} \mathrm{and} \mathrm{finally} 1,5 \mathrm{ml} \mathrm{10 \%}$ SDS. This gel mixture was shaken overnight at $4{ }^{\circ} \mathrm{C}$ and subsequently for $2 \mathrm{hrs}$ at room temperature and filtred. The filtrate was lyophylized, resuspended in $5 \mathrm{ml} \mathrm{dH}_{2} \mathrm{O}$ and lyophylized again to total dryness. The Coomassie blue dye was removed by methanol extraction with freezing. The sample was then brought up in $1 \%$ SDS in $100 \mathrm{mM} \mathrm{NaCl}, 10 \mathrm{mM} \mathrm{Na}$ phosphate $\mathrm{pH} 7.510 \mathrm{mM} \mathrm{NaN}_{3}$ and dialyzed against $10 \mathrm{mM} \mathrm{Na}$ phosphate $\mathrm{pH} 7.5 \mathrm{con}-$ taining $100 \mathrm{mM} \mathrm{NACl} 0.05 \%$ SDS and $10 \mathrm{mM} \mathrm{NaN}_{3}$.

\subsection{Fetal bovine and denervated rat $\mathrm{AChR}$}

Fetal bovine and denervated rat AChR were isolated similarly as electric organ AChR (3). Special care was taken to avoid proteolysis since muscle tissue is rich in proteases. Muscle tissue was homogenized with 3-6 volumes of $10 \mathrm{mM}$ Na Phosphate buffer $\mathrm{pH}$ 7.5 , containing $10 \mathrm{mM} \mathrm{NaN}_{3}, 10 \mathrm{mM}$ iodoacetamide, $10 \mathrm{mM}$ imidazole, $1 \mathrm{mM}$ phenylmethanesulfonylfluoride (PMSF), 1/1000 aprotinin (Trasylol ${ }^{\mathrm{R}}$, Bayer) in a Warring blendor for $1 \mathrm{~min}$. at high speed and centrifuged at $10.000 \mathrm{rpm}$ in a Beckman JA-10 rotor. The pellet was resuspended in the same buffer and centrifuged again. The pellet 
was resuspended with a Warring blendor for $15 \mathrm{sec}$ at low speed in $2 \%$ Triton X-100 phosphate buffer and the extraction was continued by gently shaking. The homogenate was centrifuged for $30 \mathrm{~min}$. at $10.000 \mathrm{rpm}$ in a JA-10 rotor. The supernatant was centrifuged at $30.000 \mathrm{rpm}$ for $30 \mathrm{~min}$. in a Beckman no. 30 rotor. The pellet was discarded and the supernatant applied to a Toxin-sepharose column run and eluted similarly as for electric organ AChR. The muscle AChR appeared equally pure on a $10 \%$ polyacrylamide SDS gell using a discontinuous buffer system according to Laemmli (4).

\subsection{Chemical alteration of Torpedo AChR}

Reduced and carboxymethylated AChR (RCM-AChR) (5)

Six $\mathrm{ml}$ affinity purified Torpedo AChR $(0,8 \mathrm{mg} / \mathrm{ml})$ was dialyzed against $6 \mathrm{M}$ guanidine $\mathrm{HCl}$ in $0.2 \mathrm{M}$ Tris buffer $\mathrm{pH}$ 7.0. Next the AChR preparation was reduced in 0.1 M 2- $\beta$-mercaptoethanol for 60 minutes at $37^{\circ} \mathrm{C}$ under nitrogen. Then iodoacetamide was added to a final concentration of $0.15 \mathrm{M}$ maintaining the $\mathrm{pH}$ at 8.2 for 15 minutes with $2 \mathrm{M}$ Tris buffer. The sample was then dialysed twice against 100 volume $0,2 \%$ cholate, $10 \mathrm{mM}$ Tris- $\mathrm{HCl} \mathrm{pH} 7.5,100 \mathrm{mM} \mathrm{NaCl}, 1 \mathrm{mM}$ EDTA, $1 \mathrm{mM}$ PMSF and $10 \mathrm{mM}$ $\mathrm{NaN}_{3}$. The recovery, as measured by a Lowry protein assay was $100 \%$. The RCM$\mathrm{AChR}$ did not bind ${ }^{125} \mathbb{I}-\alpha$-BGT when assayed under conditons as for AChR determinations.

\section{Trypsinized Torpedo AChR}

Torpedo AChR was proteolyzed with trypsin under controlled conditions. To one $\mathrm{ml}$ Torpedo AChR $(1 \mathrm{mg} / \mathrm{ml})$ in $0.2 \%$ cholate-PBS, $20 \mu \mathrm{l} 0.01 \mathrm{mg} / \mathrm{ml}$ trypsin and $1 \mathrm{mM}$ $\mathrm{HCl}$ was added and incubated at room temperature for $2 \mathrm{hr}$. The reaction was stopped by addition of 2 nmoles of PMSF ( $8 \mu \mathrm{l}$ of $1 \mathrm{mM}$ PMSF in isopropanol). This trypsinized AChR retained the capacity to bind ${ }^{125} \mathrm{~T}-\alpha-\mathrm{BGT}$.

\subsection{Purification of AChR-rich vesicles}

AChR-rich vesicles were prepared by Dr. R. Anholt in the Receptor biology laboratory (director Dr. J.M. Lindstrom) at the Salk Institute (San Diego, USA) according to a published procedure (1). The crude membrane pellet as described above was resuspended in 3 volumes of $10 \mathrm{mM}$ Na phosphate, $\mathrm{pH} 7.5,1 \mathrm{mM}$ EDTA, $10 \mathrm{mM} \mathrm{NaN} 3$ in a Virtis homogenizer $4 \times 30 \mathrm{sec}$. at high speed on ice. Then $4 \mathrm{M} \mathrm{NaCl}$ was added to a final concentration of $0.4 \mathrm{M}$ and $60 \%$ sucrose to a final concentration of $32 \%$ (w/w) and the mixture was homogenized again for $2 \times 30 \mathrm{sec}$. This suspension was layered at $11.5 \mathrm{ml} /$ tube over $14.5 \mathrm{ml}$ of $36 \%$ (w/w) sucrose in $0.4 \mathrm{M} \mathrm{NaCl}, 10 \mathrm{mM}$ Na phosphate, pH 7.5, $1 \mathrm{mM}$ EDTA, $10 \mathrm{mM} \mathrm{NaN3}$. After centrifugation for $50 \mathrm{~min}$ at $50,000 \mathrm{rpm}$ in a Beckman Ti-60 rotor, the floating fat pad and pellet were discarded. The band of AChR-rich membranes was collected, diluted to $30 \%$ sucrose, and then centrifuged for $45 \mathrm{~min}$ at $50,000 \mathrm{rpm}$ in the Ti-60 rotor. For further purification of $\mathrm{ACh} \mathbf{R}$ in intact 
membranes, this pellet was resuspended in a minimal volume of flux buffer $(145 \mathrm{mM}$ sucrose, $10 \mathrm{mM}$ Na phosphate buffer, pH 7.5, $5 \mathrm{mM} \mathrm{NaN}_{3}$ ) using a Polytron homogenizer for $3 \times 30 \mathrm{sec}$. at high speed on ice. Then aliquots of approximately $12 \mathrm{ml}$ were layered on $54 \mathrm{ml}$ of linear 31 to $39 \%$ sucrose gradients (in $10 \mathrm{mM}$ Na phosphate buffer, pH 7.5, $1 \mathrm{mM}$ EDTA, $10 \mathrm{mM} \mathrm{NaN}_{3}$ ). These gradients were centrifuged overnight at $25,000 \mathrm{rpm}$ in a Beckman SW 27 rotor. The upper layer and pellet were discarded and the midband dilluted 1:1 with flux buffer and then centrifuged at $50,000 \mathrm{rpm}$ for $50 \mathrm{~min}$ in the Ti-60 rotor. The resulting pellet was resuspended in a minimal volume of flux buffer using an 18-gauge needlle and syringe, and then homogenized in a motor-driven homogenizer with a Teflon pestle. This was the purified vesicle fraction.

\subsection{Reconstitution of AChR in liposomes}

AChR containing and control liposomes (containing no AChR) were also prepared by R. Anholt according to a published procedure (1). Reconstruction buffer ( $2 \% \mathrm{Na}$ Cholate, Interchem, Montlucon, France), $25 \mathrm{mg} / \mathrm{ml}$ of soybean L- $\alpha$-phosphatidylcholine (Sigma, commercial grade), $100 \mathrm{mM} \mathrm{NaCl}, 10 \mathrm{mM}$ phosphate buffer, $\mathrm{pH} 7.5,10 \mathrm{mM}$ $\mathrm{NaN}_{3}$ ) was prepared by three cycles of stirring the ingredients together at room temperature, freezing, and thawing. The solution was then centrifuged $30 \mathrm{~min}$ at $30,000 \mathrm{rpm}$ in a Beckman no. 30 rotor to remove any unsolubilized lipid. This solution was then aliquoted and stored frozen. Reconstitution buffer was also made by dilution of a 150 $\mathrm{mg} / \mathrm{ml}$ stock of lipid in water sonicated under argon to clarity in a bath-type sonicator at $4^{\circ} \mathrm{C}$. The method by which cholate/lipid mixtures were made had no effect on the activity of $A C h R$ in the reconstituted membranes. Vesicles were resuspended in reconstitution buffer at concentrations of 0.1 to $6 \mathrm{mg}$ of protein $/ \mathrm{ml}$. After blending on a Vortex mixer and stirring to provide homogeneous suspension, this mixture was dialyzed overnight against at least 100 volumes of $100 \mathrm{mM} \mathrm{NaCl}, 10 \mathrm{mM} \mathrm{Na}$ phosphate, pH 7.5, $10 \mathrm{mM} \mathrm{NaN}_{3}$ followed by an additional overnight dialyzis against flux buffer.

\section{IMMUNIZATIONS}

Rats were injected with Torpedo AChR ( 5 to $20 \mu \mathrm{g}$ ) or fetal calf AChR ( 1 or $15 \mu \mathrm{g}$ ) in $0.1 \mathrm{ml}$ phosphate-buffered saline emulsified in an equal volume of complete Freund's adjuvant containing nine parts Marcol-52 to one part of Arlacel A with $1 \mathrm{mg}$ mycobacterium tuberculosis H 37 RA (Difco Laboratories, Detroit, MI). The emulsion was injected subcutaneously in the footpads, the base of the tail, and several other sites on the lower back. In some experiments the animals were boosted 4 weeks after initial sensitization with an equal amount of the same emulsion. The animals were sacrified 5 to 6 weeks after the primary immunization. 


\section{LYMPHOCYTE CULTURE SYSTEM}

\section{1 preparation of crude lymphocyte suspensions}

Popliteal, inguinal and para-aortic lymph nodes and spleens were removed under aseptic conditons. Lymph nodes were freed of fat. Simple cell suspensions were prepared by forcing the lymph nodes or spleens through a stainless screen. The suspension was subsequently filtered through a nitex screen (110 $\mu \mathrm{m}$ opening) followed by three washes in Hanks' balanced salt solution (HBSS). The viability of the cells assessed by Trypan blue exclusion was between $60-70 \%$. Peripheral blood lymphocytes were purified from heparinized $(40 \mathrm{IU} / \mathrm{ml})$ blood obtained by cardiac puncture. Whole blood was diluted 1:2 with HBSS. Lymphocytes were purified on Ficoll-Hypaque (Pharmacia) and freed from platelets on a discontinuous sucrose gradient (12 and 16\% sucrose) according to the procedure of Perper et al. (6) with a yield of 1 to $1.5 \times 10^{6} \mathrm{cells} / \mathrm{ml}$ whole blood. Viability assayed by trypan blue exlusion was $95 \%$.

\subsection{Depletion of $T$ lymphocytes}

Lymph node cells were treated with anti-rat brain serum (anti-RB-serum) and complement to deplete $T$ cells before culture. The method of Golub (7) as modified by OrtizOrtiz et al. (8) was used to prepare rabbit antiserum to brain-associated thymus antigen of rats (anti-RB serum). The antiserum was sequentially adsorbed on 1/3 volume Lewis rat erythrocytes, $1 / 3$ packed volume of washed homogenized syngeneic kidney tissue, and 1/9 packed volume of rat $\mathrm{Y} 3-\mathrm{Ag} 1.2 .3$ myeloma cells. The specificity of the anti$\mathrm{RB}$ antiserum was evaluated by using a complement-dependent cytotoxicity test on thymus, bone marrow and lymph node cells labeled with ${ }^{57} \mathrm{Cr}$ as described by Golub (7). By this technique the antiserum was proved to be $T$ cell-specific. Lymph node cells $\left(5 \times 10^{7} / \mathrm{ml}\right)$ were incubated with an equal volume of anti-RB serum diluted $1 / 10$ in HBSS for $30 \mathrm{~min}$ at $4^{\circ} \mathrm{C}$. The cells were then washed in HBSS and incubated with 1 $\mathrm{ml}$ of a mixture of low toxicity rabbit complement and guinea pig complement $(1: 2$. $\mathrm{v} / \mathrm{v}$ ) for $30 \mathrm{~min}$ at $37^{\circ} \mathrm{C}$. This treatment abolished the proliferative response to concanavalin A by greater $90 \%$.

\subsection{Depletion of macrophages}

Lymph node cells were filtered through Sephadex G-10 columns (Pharmacia) by the method of Ly and Mishell (9). Lymph node cells $\left(5 \times 10^{7}\right)$ in $2 \mathrm{ml} 5 \%$ FCS-RPMI 1640 were applied to a column of Sephadex G-10 $(4.5 \times 0.5 \mathrm{~cm})$ and allowed to penetrate. The column was eluted with the same media and the first $3 \mathrm{ml}$ of effluent were discar-

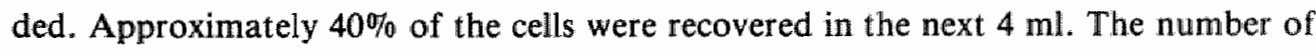
macrophages, measured by nonspecific esterase staining (10), was reduced from $3 \%$ to less than $0.1 \%$ after passage over the column. 


\subsection{Depletion of $T$ helper cells by fluoresence activated cell sorting (FACS)}

Antibodies.

A monoclonal mouse anti-rat $T$ cell antibody (W3/25) described by Williams et al. (11) (Sera Lab Ltd. Sussex, England) was used to identify and isolate rat T lymphocytes by indirect immunofluorescence. Fluorescence-labeled $F(a b) 2$ fragments of goat antimouse IgG (Cappel Laboraories) were passed over a rat IgG Sepharose 4B column to render it specific for mouse IgG. This preparation stained less than $1 \%$ of rat lymphocytes directly by fluorescence.

\section{Cell staining.}

Lymphocytes obtained from animals with chronic EAMG were stained by incubating $30 \times 10^{6}$ cells purified by Ficoll-Hypaque (Pharmacia) with $200 \mu \mathrm{g}$ of W3/25 in a volume of $1 \mathrm{ml}$ of RMPI 1640, supplemented wit $5 \%$ rat serum, and were incubated for $30 \mathrm{~min}$ at $4^{\circ} \mathrm{C}$. Cells were washed two times and resuspended in RPMI 1640 containing 5\% rat serum and $0.01 \% \mathrm{NaN}_{3}$, incubated with $120 \mu \mathrm{g}$ fluorescein-labeled goat $\mathrm{F}(\mathrm{ab})_{2}$ antimouse IgG for 30 min and washed two times in RPMI with $5 \%$ rat serum.

\section{Analysis and cell sorting.}

Fluorescence intensity and light scatter were determined in a fluorescence-activated cell sorter (FACS IV, Becton Dickinson, FACS Systems, Mountain View, CA). The preamplifier and laserbeam were adjusted the way that the fluorescence peak was at channel 180 and the light scattering peak was at channel 85 when $4.25 \mu \mathrm{m}$ fluorescent beads were tested (Duke Scientific, Palo Alto, CA). Lymphocytes were sorted in a FACS into $\mathrm{W} 3 / 25^{+}$and $\mathrm{W} 3 / 25^{-}$populations. Cells in channels 1 to 25 were deflected left and those in channels 50 to 225 were deflected right. Of the $\mathrm{W} 3 / 25^{+}$population, $98 \%$ were positively stained after examination of the sorted cells, whereas the $\mathrm{W} 3 / 25^{-}$deflected population was contaminated with less than $5 \% \mathrm{~W} 3 / 25^{+}$cells.

\subsection{Lymphocyte proliferation (12)}

The cells obtained by the procedures described above $(4.1-4.4)$ were resuspended at a concentration of $1 \times 10^{6}$ cells $/ \mathrm{ml}$ in RPMI 1640 (Flow Laboratories) supplemented with $5 \%$ Lewis rat serum, $100 \mathrm{U}$ penicillin, $100 \mu \mathrm{g}$ streptomycin, and $5 \times 10^{-5} \mathrm{M} 2$-mercaptoethanol. Triplicate cultures of $2 \times 10^{5}$ cells $/ 0.1 \mathrm{ml}$ were incubated in flat-bottomed microtiter plates ( 3040 microtest II, Falcon Plastics, Oxnard, PA) for 5 days at $37^{\circ} \mathrm{C}$ in $5 \%$ $\mathrm{CO}_{2}$ in a humidified atmosphere. One hundred microliters of AChR previously dialyzed against $250 \mathrm{ml}$ PBS and diluted in RPMI 1640 is added to each well at the start of the culture to give a concentration ranging from $0.005 \mu \mathrm{g} / \mathrm{culture}\left(2 \times 10^{-10} \mathrm{M}\right)$ to $0.5 \mu \mathrm{g} /$ culture $\left(2 \times 10^{-8} \mathrm{M}\right)$. The cultures were pulsed with $1 \mu \mathrm{Ci}$ tritiated thymidine ( $\left[{ }^{3} \mathrm{H} \| \mathrm{TdR}, 5 \mathrm{Ci} / \mathrm{mM}\right.$, Amersham, England), $24 \mathrm{hr}$ before the cells were harvested with an automated cell harvester. The filters (Titertek Harvest filters no. 78-105-05) were 
dried, placed in $3 \mathrm{ml}$ of scintillation fluid (OCS, Amersham, England) and counted in a scintillation counter. The results are expressed as mean counts per minute (cpm) minus background of triplicate cultures \pm standard error. In some instance the background values (although substracted) are also given.

\subsection{Antibody synthesis in vitro}

Immune lymphocytes $\left(1 \times 10^{6}\right.$ cells $\left./ \mathrm{ml}\right)$ obtainned by the pracedures described above (4.1-4.4) are cultured in triplicate wells in the presence of increasing amounts of Torpedo $A C h R$ in $100 \mu$ LPMI 1640 supplemented as described in the proliferation assay for 5 days in a humidified atmosphere of $5 \% \mathrm{CO}_{2}$. The cells are then centrifuged in the microtiter plates at $200 \mathrm{~g}$ at room temperature and washed once with $200 \mu \mathrm{l} \mathrm{RPMI}$ 1640 to remove $A C h R$ that might interfere with the radioimmunoassay. After resuspending the cells in $200 \mu \mathrm{l}$ supplemented medium, the cultures are incubated for an additional 24 hours. Aliquots $(50 \mu \mathrm{l})$ of the tissue culture fluid were assayed for antibody $A C h R$ by radioimmunoassay (vide infra).

\section{RADIOIMMUNOASSAY OF ANTI-ACHR ANTIBODY}

Titers of serum antibodies to Torpedo, rat or fetal bovine muscle were measured by indirect immunoprecipitation using ${ }^{125} \mathrm{I}-\alpha$ bungarotoxin-labeled AChR as antigen and goat anti-rat immunoglobulin as second antibody (13).

\subsection{Preparation of antigen}

Crude extracts of AChR of electric organ, fetal bovine muscle or denervated rat muscle were prepared as described for the crude membrane preparation of electric organ. Minced half thawed muscle was homogenized in a Warring blendor at $4^{\circ} \mathrm{C}$ in 2 volumes $10 \mathrm{mM}$ Na phosphate buffer, $1 \mathrm{mM}$ iodoacetamide and $1 \mathrm{mM}$ PMSF, pH 7.4, $100 \mathrm{mM}$ $\mathrm{NaCl}, 10 \mathrm{mM} \mathrm{NaN}_{3}$, for 1 minute at high speed then centrifuged in a Beckman JA 10 or JA-14 rotor at $10.000 \mathrm{rpm}$ or $14.000 \mathrm{rpm}$ respectively. The resulting pellet was ex tracted with 2 volumes of $2 \%$ Triton X-100 in $10 \mathrm{mM} \mathrm{Na}$ phosphate $\mathrm{pH} 7.4,100 \mathrm{mM}$ $\mathrm{NaCl}, 10 \mathrm{mM} \mathrm{NaN} 3,1 \mathrm{mM}$ iodoacetamide and $1 \mathrm{mM}$ PMSF by shaking for $2 \mathrm{hrs}$. The supernatant after centrifugation for $60 \mathrm{~min}$ at $100.000 \mathrm{~g}$ was used as antigen in the radioimmunoassay.

\subsection{Radiolabeling of $\alpha$-bungarotoxin}

Alfa-bungarotoxin ( $\alpha$-BGT) from Bungarus multicinctus was purified according to Lee et al. (14) or purchased purified from Miami Serpentarium (Miami, Florida, USA). Radiolabeling of $\alpha$-BGT was performed as described by J. Lindstrom et al. (13). To $5 \mathrm{mCi}$ carrier-free ${ }^{125} \mathrm{I}$ ( $N$ ew England Nuclear or Amersham) was added $10 \mu \mathrm{l} 0.1$ 
$\mathrm{M} \mathrm{Na}$ phosphate buffer $\mathrm{pH} 7.0$ followed by a few drops $1 \mathrm{M} \mathrm{HCl}$ to neutralize the $\mathrm{NaOH}$ in which ${ }^{125} \mathrm{I}$ was shipped. $\alpha$-Bungarotoxin $\left( \pm 0,5 \mathrm{mg}\right.$ or $2,4 \times 10^{-8}$ moles) and $\mathrm{NaI}$ (28 nmoles) were added in $50 \mu \rrbracket$ of $0.1 \mathrm{M}$ Na phosphate $\mathrm{pH} 7.0$. Chloramine $\mathrm{T}$ was added ( $10 \mu \mathrm{l}$ containing $28 \mathrm{nmoles}$ ) and the solution was mixed on a magnetic stirrer at $4^{\circ} \mathrm{C}$ for 10 minutes. The sample along with $100 \mu \mathrm{l}$ of buffer was applied to a disposable G25 collumn $(0,5 \times 10 \mathrm{~cm})$ preequilibrated with $2 \mathrm{ml} \mathrm{BSA}(1 \mathrm{mg} / \mathrm{ml})$ and washed with 5 column volumes of $0.1 \mathrm{M} \mathrm{Na}$ phosphate buffer $\mathrm{pH} 7.0$. The column was eluted with the same buffer. ${ }^{125} \mathrm{I}-\alpha$-bungarotoxin elutes in the void volume along with $90 \%$ of radioactiwity. The ${ }^{125} \mathrm{I}-\alpha$-BGT was adjusted to a concentration of $2 \times 10^{-8} \mathrm{M}$, BSA was added to a concentration of $1 \mathrm{mg} / \mathrm{ml}$ and the samples $(200 \mu \mathrm{l})$ stored frozen at $-70^{\circ} \mathrm{C}$. Sometimes smaller badges of $\alpha$-BGT $(+50 \mu \mathrm{g}$ ) were labeled by omitting NaI and reducing chloramine- $\mathrm{T}$ to 2,4 nmoles and ${ }^{125} \mathrm{I}$ to $1 \mathrm{mCi}$. The specific activity of ${ }^{125} \mathrm{I}-$ $\alpha$-BGT varied from $2-3 \times 10^{17} \mathrm{cpm} /$ mole.

\subsection{Measurement of AChR concentration}

Concentration of AChR was estimated by measuring ${ }^{125}$ I- $\alpha$-BGT binding $(13,15)$. Allquots of receptor $(10-100 \mu \mathrm{l})$ were incubated $4 \mathrm{hr}$ with $2.10^{-9} \mathrm{M}{ }^{125} \mathrm{I}-\alpha$-BGT in $0,5 \%$ Trition X-100-PBS-NaN 3 or with $10^{-3} \mathrm{M}$ acetylcholine and $10^{-3} \mathrm{M}$ neostigminebromide to inhibit the binding of ${ }^{125} \mathrm{I}-\alpha-\mathrm{BGT}$ to the acetylcholine binding site of $\mathrm{AChR}$. The ${ }^{125} \mathrm{I}-\alpha$-BGT-AChR complex was incubated overnight with $5 \mu \mathrm{l}$ of pooled serum of rats with EAMG at $4^{\circ} \mathrm{C}$. Then $100-150 \mu$ l of goat anti-rat gammaglobulin serum (50\% ammoniumsulfate precipitate) was added to precipitate immune complexes. After $4 \mathrm{hr}$ at $4^{\circ} \mathrm{C}$ the samples were centrifuged in a Eppendorf microfuge $( \pm 10.000 \mathrm{~g})$ for $2 \mathrm{~min}$, the pellet was washed with $1 \mathrm{ml} 0,5 \%$ Triton $\mathrm{X}-100-\mathrm{PBS}-\mathrm{NaN}_{3}$ and counted in a gamma counter. ${ }^{125} \mathrm{I}-\alpha-\mathrm{BGT}$ bound in the presence of acetylcholine/neostigmine bromide $\left(10^{-3} \mathrm{M}\right)$ was substracted from the total before computing the concentration of $\mathrm{AChR}$ following the equation:

$$
\begin{aligned}
& \frac{\mathrm{cpm} / 1}{\text { specific activity of }{ }^{125} \mathrm{I}-\alpha-\mathrm{BGT}(\mathrm{cpm} / \mathrm{mol})} \\
& =\mathrm{cpm} \times \frac{10^{6}}{\text { sample volume }} \times \frac{1}{\text { specific activity of }{ }^{125}[-\alpha \text {-BGT standard (cpm/mole) }}
\end{aligned}
$$

AChR concentration is expressed in moles toxin binding sites $/$.

\subsection{Measurements of anti- $\mathrm{AChR}$ antibody}

Anti-AChR antibody concentration was measured by immunoprecipitation using ${ }^{125} \mathrm{I}$ $\alpha$-BGT-AChR as antigen (13) AChR $\left(1 \times 10^{-9} \mathrm{M}\right)$ was labeled with ${ }^{125} \mathrm{I}-\alpha$-BGT $\left(2 \times 10^{-9} \mathrm{M}\right)$ for a minimum of $4 \mathrm{hr}$. ${ }^{125} \mathrm{I}-\alpha$-BGT-AChR was incubated in a volume of $1 \mathrm{ml} 0,5 \%$ 
Triton X-100-PBS-NaN3 buffer with $5 \mu$ diluted serum (1/100 or $1 / 500)$ overnight at $4^{\circ} \mathrm{C}$. The resulting complexes were precipitated along with carrier immunoglobulin ( 5 $\mu l$ normal rat serum) by addition of $100-150 \mu$ goat anti rat immunoglobulin ( $50 \%$ ammoniumsulfate precipitate). After $4 \mathrm{hr}$ incubation at $4^{\circ} \mathrm{C}$, the samples were centrifuged for $2 \mathrm{~min}$ in an Eppendorf centrifuge and the resulting pellet was washed once with $1 \mathrm{ml} 0,5 \%$ Triton-X-100-PBS-NaN3. Radioactivity in the resulting pellet was counted in a gamma counter. The value for ${ }^{125} \mathrm{I}-\alpha$-BGT-AChR pelleted in the presence of normal rat serum $(5 \mu 1)$ was substracted from the assay value. The antibody titer was calculated from the moles ${ }^{125} \mathrm{I}-\alpha$-BGT precipitated using the following equation:

$$
=\operatorname{cpm} \times \frac{10^{6}}{\text { sample volume }} \times \frac{\text { dilution of serum sample }}{\text { specific activity of }{ }^{125} \mathrm{I}-\alpha \mathrm{C} \text {-BGT standard }(\mathrm{cpm} / \mathrm{mole})}
$$

The titer is expressed in moles of toxin/liter serum.

Example:

assay values: $20500,21000,20750 \mathrm{cpm}$

background: $1280,1265,1300 \mathrm{cpm}$

sample volume: $5 \mu \mathrm{l}$

dilution: $1 / 100$

specific activity of the ${ }^{125} \mathrm{I}-\alpha-\mathrm{BGT}$ standard: $3.25 \times 10^{17} \mathrm{cpm} / \mathrm{ml}$ (corrected for radioactive decay)

equation for calculating titer:

$=19468 \times \frac{10^{6}}{5} \times \frac{100}{3,25 \times 10^{17}}=1.198 \times 10^{-6}$ moles toxin binding sites $/ 1$ serum.

When anti-Torpedo AChR antibody titers were compared to anti-fetal calf AChR antibody titers, the anti-torpedo $\mathrm{ACh} R$ titers were divided by 1,7 to correct for the presence of dimers $(70 \%)$ present in Torpedo AChR preparations.

\section{DETERMINATION OF ANTI-ACHR ANTIBODY SPECIFICITY BY ENZYME IMMUNOASSAY}

Anti-AChR antibody binding to solid phase AChR was measured using glucosoxidasegoat anti rat Ig conjugates as described by R. Johnson (16). Microtiter plates (Dynatech Immulon type I, flat bottom) were incubated with $1 \times 10^{-12} \mathrm{~mol}$ affinity purified (125 $\mathrm{ng}$ ) Torpedo AChR in $50 \mu \mathrm{l}$ of $0.01 \mathrm{M} \mathrm{Na}$ bicarbonate buffer pH 9.6 and dried under vacuum overnight at room temperature. Under these conditions $5.5 \mathrm{ng}$ AChR (44 pmoles) or $4.4 \% \pm 0.5(\mathrm{~m} \pm \mathrm{SD}, \mathrm{n}=16)$ of the $\mathrm{AChR}$ added bound to the well. The wells were then incubated with $200 \mu \mathrm{l}$ BSA-PBS-Tween-buffer $(5 \mathrm{mg} / \mathrm{ml}$ bovine serum albumin, 
$0,5 \%$ Tween $20,10 \mathrm{mM}$ phosphate $\mathrm{pH} 7.5,100 \mathrm{mM} \mathrm{NaCl}$ and $10 \mathrm{mM} \mathrm{NaN}$ ) for 15 minutes at room temperature to saturate unbound sites on the plastic. Wells were then washed three times with PBS-Tween-buffer. The acetylcholine binding site was then saturated by incubation with an excess of acetylcholine $\left(10^{-3} \mathrm{M}\right)$ and neostigmine bromide $\left(10^{-3} \mathrm{M}\right)$ in a volume of $50 \mu \mathrm{l}$ for $2 \mathrm{hr}$. Then $50 \mu \mathrm{l}$ of serial dilutions of EAMG serum in BSA-PBS-Tween buffer were added without washing the wells. After $2 \mathrm{hr}$ incubation on a rocker platform, wells were washed 3 times with $200 \mu$ I PBS-Tween-buffer prior to addition of $50 \mu \mathrm{l}$ goat anti-rat IgG conjugates to glucosoxidase (a gift of R. Johnson, Reagent Applic. Inc., San Diego, USA) and incubated $1 \mathrm{hr}$ at room temperature. After three washes with PBS-Tween-buffer, $200 \mu$ l enzyme substrate was added. This substrate consisted of 24 volumes of $10 \mathrm{mM} \mathrm{Na}$ phosphate buffer, $100 \mathrm{mM} \mathrm{NaCl}, 3$ volumes of $18 \%$ glucose, one volume of $0.02 \%$ horseradish peroxidase (type VI, sigma) and 0.2 volumes of $2 \%$ ABTS (2,2'-Azino-di-3-ethyl-benzthiazoline-6-sulfonate). After 60 minutes the $O . D_{414 n m}$ was read using a titertek multiscan (Flow laboratories). Background values for $\mathrm{AChR}$ coated wells not exposed to antibody were substracted.

\section{INTERLEUKIN-2}

\subsection{Assay of Interleukin-2 (IL-2)}

IL-2 activity was assayed on aliquots of tissue culture supernatants using an IL-2 dependent cytotoxic T cell line (CTLL-2 line)(17). This cell line was maintained in bulk cultures at $1 \times 10^{5}$ cells $/ \mathrm{ml}$ in RPMI- 1640 medium supplemented with $5 \%$ fetal calf serum, $1 \%$ glutamine, $100 \mathrm{U}$ penicillin, $100 \mu \mathrm{g}$ streptomycin and $5 \times 10^{-5} \mathrm{M} 2-\beta$-mercaptoethanol in a humidified atmosphere of $5 \% \mathrm{CO}_{2}$. Before the assay, the cells were washed 3 times with PBS and pippetted in microtiter wells at $5 \times 10^{3}$ cells/well in RPMI 1640 supplemented as described above. Aliquots of the tissue culture supernatants (10-100 $\mu$ ) to be assayed for $\mathbb{I L}-2$ activity, were added and the cells were cultured for $24 \mathrm{hrs}$ in $5 \% \mathrm{CO}_{2}$. The next day the cells were pulsed with $1 \mu \mathrm{Ci}{ }^{3} \mathrm{H}-\mathrm{TdR}$ six hours before harvest with an automated cell harvester. The filters were dried, placed in $3 \mathrm{ml}$ of scintillation fluid (OCS, Amersham or Atomlight, NEN) and counted in a liquid scintillation counter. The results are expressed as mean counts per minute minus the background of tripilicate cultures \pm standard error.

\subsection{Purification of interleukin-2}

Interleukin-2 was partially purified from tissue culture supernatants of Con A stimulated spleen cells by gel permeation chromatography on a ACA- 44 column. Spleen cells $\left(5 \times 10^{6} / \mathrm{ml}\right)$ from Lewis rats were cultured for $48 \mathrm{hrs}$ in serum-free RPMI- 1640 medium supplemented with Con A $(2 \mu \mathrm{g} / \mathrm{ml})$ and $0.01 \%$ polyethyleneglycol (MW 4000$)$. The culture supernatants were concentrated under nitrogen on a YM 5 Amicon concentrating apparatus. The concentrated supernatants were applied on a ACA 44 column equi- 
librated with PBS and eluted with the same buffer. IL-2 containing fractions (MW $12,000-18,000)$ were pooled. The IL-2 preparation used for this study contained 1250 $\mathrm{U} / \mathrm{ml}$ (one unit being the amount of supernatant that gives a half maximal proliferation of $5 \times 10^{3}$ CTLL cells).

\section{MONOCLONAL ANTIBODIES}

The monoclonal antibodies used in this study prepared by Dr. S.J. Tzartos (Institute Pasteur Hellenic, Athens, Greece) in the Receptor Biology laboratory at the Salk Institute (Director Dr. J.M. Lindstrom) $(18,19)$. Lewis, Sprague Dawley an Louvain rats received several subcutaneous injections of purified, native, or SDS denatured AChR in CFA. Animals were killed 3 to 5 days after the last booster injection and their spleen cells fused with either the mouse myeloma cell line S 194 (non secreter line) or with the rat LOU myeloma Y3 cell line (kappa chain secretor line). Spleen cells ( $\left.1 \times 10^{8}\right)$ were fused with S 194 cells $\left(1.5 \times 10^{7}\right)$ or with Y 3 cells $\left(5 \times 10^{7}\right)$ using $50 \%$ polyethylene glycol 1500. Hybrids derived from S 194 myeloma form tight colonies in agar; therefore they were isolated using a "direct cloning method" (19). Briefly after fusion and washing, the cells were suspended in $15 \mathrm{ml}$ warm $0.25 \%$ Agar in HAT medium. The resulting cell suspension in agar was quickly dispensed into $48(2 \mathrm{ml})$ wells $(0,3 \mathrm{ml} /$ well $)$. The next day $1,5 \mathrm{ml}$ of HAT medium was added to each well. Three to four half-replacements of the HAT medium followed during the next 2 weeks. Then the supernatants were assayed for anti-AChR antibody. Colonies in antibody-containing wells were transferred into microtiter wells $(0.2 \mathrm{ml})$ using a pasteur pipette. After 2 days the supernatants were assayed for anti-AChR antibody. This direct cloning technique avoids that the faster growing non producing hybrids overgrow the slow growing antibody producing hybrids. Recloning was performed by several dilutions in agar. Hybrids derived from $Y 3$ cells all were cloned by the classical limiting dilutions technique (20) because they do not form condensed colonies in agar. Immunoglobulin fractions of the culture media from the cloned hybrids formed in large volumes were isolated and concentrated via $40-45 \%$ ammoniumsulfate precipitation and dialyzed against $10 \mathrm{mM} \mathrm{Na}$ phosphate buffer $\mathrm{pH} 7.5,100 \mathrm{mM} \mathrm{NaCl}, 10 \mathrm{mM} \mathrm{NaN}_{3}$. Determination of Ig class and subclass was done by immunodiffusion using anti-rat Ig subclass antisera (a gift from H. Bazin, University of Louvain, Belgium) and known controls. The characteristics of the rat monoclonal antibodies used in this study are depicted in table $\mathrm{I}$. 
Table 1: Characteristics of monoclonal antibodies against AChR

\begin{tabular}{|c|c|c|c|c|}
\hline MAB nr. & $\begin{array}{l}\text { Immunogen } \\
(\mathrm{AChR})\end{array}$ & Isotype & $\begin{array}{l}\text { Cross reaction } \\
\text { anti mammalian }\end{array}$ & $\begin{array}{l}\text { subsequent } \\
\text { specificity }\end{array}$ \\
\hline 1 & Torpedo & $\operatorname{IgG} 2 b$ & - & $\alpha$ (MIR) \\
\hline 2 & Torpedo & $\operatorname{IgG} 2 a$ & - & $\alpha($ MIR) \\
\hline 3 & Torpedo & $\operatorname{IgG} 2 b$ & - & $\alpha$ \\
\hline 4 & Torpedo & $\operatorname{IgG} 2 b$ & - & $\alpha(\mathrm{MIR})$ \\
\hline 5 & Torpedo & $\operatorname{IgG} 2 b$ & - & $\alpha$ \\
\hline 6 & Torpedo & $\lg G 1$ & + & $\alpha(\mathrm{MIR})$ \\
\hline 7 & $\begin{array}{l}\text { Torpedo } \\
\alpha \text {-subunit }\end{array}$ & $\operatorname{lgG} 1$ & - & $\alpha$ \\
\hline 8 & $\begin{array}{l}\text { Torpedo } \\
\alpha \text {-subunit }\end{array}$ & $\operatorname{IgG} 2 \mathrm{a}$ & - & $\alpha$ \\
\hline 11 & $\begin{array}{l}\text { Torpedo } \\
\alpha \text {-subunit }\end{array}$ & IgM & - & $\beta$ \\
\hline 12 & Torpedo/Eel & $\operatorname{IgG} 2 b$ & + & $\alpha(\mathbf{M} I R)$ \\
\hline 14 & Torpedo/Eel & IgA $2 a$ & + & $\alpha(\mathrm{MIR})$ \\
\hline 16 & Torpedo/Eel & $\lg G 1$ & + & $\alpha(\mathrm{MIR})$ \\
\hline 17 & Torpedo/Eel & $\operatorname{IgG} 2 b$ & + & $\alpha \beta \gamma$ \\
\hline 19 & Torpedo/Eel & IgG $2 b$ & 0 & $\alpha \beta \gamma$ \\
\hline 22 & Eel & $\operatorname{IgG} 2 b$ & 0 & $\alpha(\mathrm{MIR})$ \\
\hline 28 & Eel & $\operatorname{IgG~} 2 \mathrm{a}$ & + & $\alpha(\mathrm{MIR})$ \\
\hline 35 & Eel & IgG 1 & + & $\alpha(\mathrm{MIR})$ \\
\hline 37 & Eel & IgG $2 a$ & + & $\alpha(\mathrm{MIR})$ \\
\hline 61 & Denatured Eel & $\operatorname{IgG} 2 \mathrm{a}$ & + & $\alpha \gamma$ \\
\hline 65 & Fetal Calf & $\operatorname{IgG} 1$ & + & $\alpha \beta$ (MIR) \\
\hline 71 & Fetal Calf & $\operatorname{Ig} G 1$ & + & $\alpha$ (MIR) \\
\hline 152 & $\begin{array}{l}\text { Subunit (Torp.) } \\
+ \text { Denatured } \mathrm{AChR}\end{array}$ & nd & + & $\alpha$ \\
\hline 153 & $\begin{array}{l}\text { Subunit (Torp.) } \\
+ \text { Denatured AChR }\end{array}$ & nd & + & $\alpha$ \\
\hline 155 & $\begin{array}{l}\text { Subunit (Torp.) } \\
+ \text { Denatured AChR }\end{array}$ & nd & + & $\alpha$ \\
\hline 157 & $\begin{array}{l}\text { Subunit (Torp.) } \\
+ \text { Denatured AChR }\end{array}$ & nd & + & $\alpha$ \\
\hline 158 & $\begin{array}{l}\text { Subunit (Torp.) } \\
+ \text { Denatured AChR }\end{array}$ & $\lg M$ & + & $\alpha$ \\
\hline 164 & $\begin{array}{l}\text { Subunit (Torp.) } \\
+ \text { Denatured AChR }\end{array}$ & nd & + & $\alpha$ \\
\hline 198 & Human & $\operatorname{lgG} 2 a$ & + & $\alpha$ \\
\hline 203 & Human & $\operatorname{IgG} 2 a$ & + & nd \\
\hline
\end{tabular}




\section{ISOELECTRIC FOCUSING}

\subsection{Analytical isoelectric focusing}

Isolectric focusing was performed according to the method of Briles and Davie (21) with some modifications (22). The vertical slab electrophoresis of 3.6\% polyacrylamide gel containing 3\% (pH 3-11) Ampholines (LKB Products, Promma, Sweden), 8M urea and $2 \%$ Nonidet $\mathrm{P}-40(\mathrm{NP}-40)$ was carried out at constant current of $5 \mathrm{~mA}$ for the first 120 minutes. After the prefocusing period the samples (diluted to a final volume of 150 $\mu \mathrm{l}$ in buffer containing $8 \mathrm{M}$ urea, $2 \% \mathrm{NP}-40$ and $3 \%$ ampholyte) were applied to the anodic end and electrophoresis was carried out at a constant current $(5 \mathrm{~mA})$ for 3 hours and subsequently at constant power ( $1 \mathrm{~W}$ ) for 12 hours at $12^{\circ} \mathrm{C}$. The focused proteins were precipitated by sequential exposure of two changes of $21 \%$ sodium sulfate (4 hours). After two changes of PBS ( 2 hours) to remove the gel by incubation in $0.4 \%$ dimethylsuberidimate hydrochloride (Sigma Chemical Co., St. Louis MC) in PBS for 2 hrs. The gels were then washed for 14 hours with 4 changes of PBS before incubation with the ${ }^{125}$ I-labeled proteins, consisting of either $50 \times 10^{-12}$ moles AChR conjugated with $100 \times 10^{-12}$ moles ${ }^{125} \mathrm{I}-\alpha$-BGT in $50 \mathrm{ml} 0.5 \%$ Triton-X-100-PBS-NaN3 or with 10 $\mu \mathrm{Ci}{ }^{125} \mathrm{I}$-labeled BSA in PBS (specific activity $1 \mu \mathrm{Ci} / \mu \mathrm{g}$ ). After incubation at $4^{\circ} \mathrm{C}$ for 14 hours, the gels were rinsed with PBS until radioactivity was absent in the washing solution and then dried at room temperature. Autoradiography of the gels used Kodak XRP-1 film (for 1-7 days).

\subsection{Preparative Isoelectric Focusing}

The gels were prepared and elctrophoresed under identical conditions as for analytical focusing, except that the spacer was omitted during the casting of the gels. After focusing and $\mathrm{pH}$ measurement the gels were sliced into $0.5 \mathrm{~cm}$ bands. Each band was eluted in $2 \mathrm{ml}$ of PBS pH 7.5 at $4{ }^{\circ} \mathrm{C}$ for 48 hours and the fractions dialyzed against PBS and concentrated by negative pressure dialysis. Antibodies to AChR from Torpedo electric organ and rat muscle were measured in each fraction by radioimmunoassay.

\section{QUANTITATION OF ACHR AND ANTI-AChR ANTIBODY COMPLEXES IN MUSCLE}

The concentration of AChR in Triton-solubilized rat muscle was determined according to Lindstrom et al (23). Each rat was processed separatly after removing intestines, skin, paws and tail. Each carcas was frozen, then minced and homogenized in $250 \mathrm{ml}$ $10 \mathrm{mM}$ Na phosphate pH 7.5, $100 \mathrm{mM} \mathrm{NaCl}, 10 \mathrm{mM} \mathrm{NaN}_{3}, 10 \mathrm{mM}$ iodoacetamide and $1 \mathrm{mM}$ PMSF in a Warring blendor for 1 minute at high speed. The homogenate was centrifuged at $10,000 \mathrm{rpm}$ in a Beckman JA-10 rotor or at $14,000 \mathrm{rpm}$ in a JA-14 rotor for $30 \mathrm{~min}$. The resulting pellet was resuspended in $150 \mathrm{ml} 0,5 \%$ Triton X-100-PBS- 
$\mathrm{NaN}_{3}$ buffer with the same additions as used for the first homogenization. After extraction ( 2 hrs on a Dubnoff shaker at low speed to avoid excessive foaming) the samples were centrifuges for $30 \mathrm{~min}$ in a JA-10 or JA-14 rotor at respectively 10,000 $\mathrm{rpm}$ or $14,000 \mathrm{rpm}$. The supernatant containing the sollublized AChR was filtered through glass wool to remove the lipid. An aliquot $(5 \mathrm{ml})$ was specifically labeled with $5 \mu{ }^{125} \mathrm{I}-\alpha$-BGT $\left(2 \times 10^{-6} \mathrm{M}\right)$ units or with $10^{-3} \mathrm{M}$ acetylcholine and $10^{-3} \mathrm{M}$ neostigmine bromide overnight at $4^{\circ} \mathrm{C}$. Labeled $\mathrm{AChR}$ was then precipitated by additon of excess rat anti-AChR serum followed by goat anti-rat Ig to measure AChR concentration or with goat anti-rat antibody only to measure AChR complexed with antibody.

\subsection{Measurement of AChR in muscle}

Half $\mathrm{ml}$ aliquots of labeled extracts (both with or without an excess acetylcholine and neostigmine bromide) were mixed with $5 \mu$ of pooled high titer rat anti-AChR serum obtained from rats with chronic EAMG. After overnight incubation, $100 \mu$ goat anti rat-immunoglobulin ( $50 \%$ ammoniumsulfate precipitate) was added and incubated for a minimum of $4 \mathrm{hr}$ at $4^{\circ} \mathrm{C}$. The tubes were centrifuged for 2 minutes in an Eppendorf microfuge and the resulting pellet was washed once with $1 \mathrm{ml} 0,5 \%$ Triton $\mathrm{X}-100-\mathrm{PBS}-\mathrm{NaN}_{3}$ buffer and pelleted again. The pellet was counted in a gammacounter and the values with acetylcholine/neostigmine bromide were substracted from the test samples. The concentration of $\mathrm{AChR}$ per rat was expressed as moles of ${ }^{125} \mathrm{I}-\alpha$ BGT binding sites/rat calculated using the following equation

$$
\text { net } \mathrm{cpm} \times \frac{10^{5}}{500} \times \frac{\text { volume of extract (liter) }}{\text { s.a. of }{ }^{125} \mathrm{I}-\alpha \text {-BGT (cpm/mol) }}
$$

\subsection{Measurements of $A C h R$ and anti-AChR antibody complexes}

One $\mathrm{ml}$ aliquots of labeled extracts (both with or without an excess of acetylcholine and neostigmine bromide) were mixed with $5 \mu l$ normal rat serum. Then the samples were processed identical as those for the measurement of $A C h R$. The concentration of anti-AChR antibody complexed with $\mathrm{ACh}$ expressed as moles ${ }^{125} \mathrm{I}-\alpha$-BGT binding sites per rat using the following equation:

$$
\text { net } \mathrm{cpm} \times \frac{10^{8}}{1000} \times \frac{\text { volume of extract (liter) }}{\text { s.a. of }{ }^{125} \mathrm{I}-\alpha-\mathrm{BGT}(\mathrm{cmp} / \mathrm{mol})}
$$

The percentage of AChR complexed with antibody was calculated for the following equation 


\section{Clinical Observations}

Animals were observed for signs of muscular weakness which was graded according to the following score: 0 , no definite weakness: + , weak grip or cry with fatigability: ++ , hunched posture with head down, movements uncoordinated, and forelimb digits flexed: and +++ , severe generalized weakness, no cry or grip, tremulous, and moribund. (23).

\section{References}

1. Lindstrom $J_{n}$ Anholt R, Einarson B, Engel A, Osame M, Montal M. Purification of acetylcholine receptors, reconstitution into lipid vesicles, and study of agonist-induced cation channel regulation. $J$. Biol. Chem 255: 8340-8350, 1980.

2. Lindstrom J, Merlie J, Yogeeswaran G. Biochemical properties of acetylcholine receptor subunits from Torpedo californica. Biochemistry 18: $4465-4470,1979$.

3. Einarson B, Gullick W, Conti-Tronconi B, Ellisman M, Lindstrom J. Subunit composition of bowine muscle acetylcholine receptor. Biochemistry 21: $5295-5302,1982$.

4. Laemmli $\mathrm{O}$. Cleavage of structural proteins during the assembly of the head of bacterinophage $\mathrm{T} 4$. $\mathrm{Na}$ ture 227: 680-685, 1970.

5. Bartfeld D, Fuchs S. Immunological characterization of an irreversably denatured acetylcholine receptor. FEBS Lett. 77: 214-218, 1977.

6. Perper RJ, Zee TW, Mickelson MM. Purification of Jymphocytes and platelets by gradient centrifuga tion. J. Lab Clin. Med. 72: 843 $448,1968$.

7. Golub ES. Brain associated theta antigen: reactivity of rabbit anti-mouse brain with mouse lymphoid cells. Cell. Immunol. 2: 353-357, 1971 .

8. Ortiz-Ortiz L, Nakamura RM, Weigle WO. T cell requirement for experimental allergic encephalomyelitis induction in the rat. J. Immunol. 117: 576, 1976.

9. Ly LA, Mishell RI. Separation of mouse spleen cells by passage through columns of sephadex G10.J. Immunol. Methods 5: 239-247, 1974.

10. Mueller J, Brun Del Re G, Buerki $H$, Keller HU, Hess MW, Cottier $H$. Nonspecific acid esterase activi ty: a criterion for differentation of $\mathrm{T}$ and $\mathrm{B}$ lymphocytes in mouse lymph nodes. Eur. J. Immunol. 5 : 270-274, 1975 .

11. White $\mathrm{RAH}_{*}$ Mason DW, Williams AF, Galfre $\mathrm{G}$ and Milstein $\mathrm{R}$. T-lymphocyte heterogenity in the rat separation of functional subpopulations using a monoclonal antibiody. J. Exp. Med. 148: 664-673, 1978.

12. De Baets MH, Ënarson B, Lindstrom JM, Weigle WO. Lymphocyte activation in experimental autoimmune myasthenia grawis. J. Immunol. 128: 2228-2235, 1982. 
13. Lindstrom JM, Lennon VA, Seybold ME, Whittingham S. Experimental autoimmune myasthenia gravis: and myasthenia gravis: biochemical and immunochemicall aspects. Ann. NY Acad. Sci. 274: $254-274,1976$.

14. Lee $C$, Chang $S, K a u ~ S, L u h ~ S$. Chromatography separation of the venom of Bungarus multicinctus and characterization of its components. J. Chromatogr. 72: 71-82, 1972.

15. Lindstrom JM. An assay for antibodies to human acetylcholine receptor in serum from patients with myasthenia gravis. Clin. Immunol. and Immunopath. 7: 36-43, 1977.

16. Johnson RB, Nakamura RM. Improved techniques in ELISA for viruses and IgG and IgM-type wiral antibodies in immunoassay. Nakamura RM, Dito WR, Tucker ES, Alan Liss, New York, pg. 142-156, 1980.

17. Gillis $\mathrm{S}$, Ferm MM, Ou W, Smith KA. T cell growth factor: parameters of production and a quantitative microassay for activity. J. Immunal. 120:2027-2032, 1978.

18. Tzartos SJ, Lindstrom JM. Monoclonal antibodies used to probe acetylcholine receptor structure: localization of the main immunogenic region and detection of simularities between subunits. Proc. Natl. Acad. Sci. 77: 755-759, 1980.

19. Tzartos SJ, Seybold ME, Lindstrom JM. Specificities of antibodies to acetylcholine receptors in sera from myasthenia gravis patients measured by monoclonal antibodies. Proc. Natl. Acad. Scil. 79: $188-192,1982$.

20. Kohler G, Milstein C. Continuous cultures of fused cells secreting antibody of predifined specificity. Nature 256: 495-501, 1975.

21. Briles DE and Davie JM. Detection of isoelectric focussed antibody by autoradiography and hemolysis of antigen-coated erythrocytes. J. Immunol. Methods 8: 363-372, 1975.

22. Bionda A, De Baets MH, Tzartos SJ, Lindstrom JM, Weigle WO, Theophiloponllos AN. Spectrotypic analysis of antibodies to acetylcholine receptors in experimental autoimmune myasthenia gravis. Clin. Exp. Immunol. 57: 41-50, 1984.

23. Lennon VA, Lindstrom JM, Seybold ME. Experimental autoimmune myasthenia: a model of myasthenia gravis in rats and guinea pigs. J. Exp. Med 141: 1365-1375, 1975. 


\section{CURRICULUM VITAE}

M.H. De Baets werd geboren op 2 april 1950 te Gent (België). Vanaf 1961 bezocht hij de humaniora afdeling van het St. Lievens College te Gent, alwaar hij in 1967 het einddiploma Latijn-Wetenschappen (gymnasium beta) behaalde. Vervolgens studeerde hij geneeskunde aan de Rijksuniversiteit te Gent waar hij in 1974 afstudeerde. Hij ving op 1 oktober 1974 zijn opleiding tot internist aan de Rijksuniversiteit te Gent. De eerste 2 jaar van deze opleiding was hij werkzaam op de afdeling inwendige ziekten van de H. Hartkliniek te Eeklo (België) met als opleider Dr. R. de Keyser die hem naast de inwendige geneeskunde ook de interesse van de immunologie bijbracht. Vanaf 1979 was hij aangesteld als assistent in de kliniek inwendige ziekten van het Akademisch Ziekenhuis te Gent. Van 1979 tot 1981 werd hij uitgezonden naar de afdeling Immunologie van de "Scripps Clinic and Research Foundation" met als begeleider Dr. W.O. Weigle (La Jolla, Verenigde Staten van Amerika) en het laboratorium voor receptor biologie van het "Salk Institute for the Biological Sciences", met als begeleider Dr. J.M. Lindstrom (San Diego, Verenigde Staten van Amerika). Sinds november 1981 is hij als wetenschappelijk medewerker in dienst van de Rijksuniversiteit Limburg, capaciteitsgroep Immunologie, waar dit proefschrift tot stand kwam onder leiding van Prof. Dr. P.J.C. van Breda Vriesman. 